May 1998

\title{
Engineering Evaluation of Hot-Gas Desulfurization with Sulfur Recovery
}

\section{Topical Report}

Work performed under

Contract No. DE-AC21-94MC31258--19

for

U.S. Department of Energy

Federal Energy Technology Center 3610 Collins Ferry Road Morgantown, WV 26505

S.K. Gangwal J.W. Portzer

Research Triangle Institute

P.O. Box 12194

Research Triangle Park, NC 27709

and

G.W. Roberts

S.C. Kozup

North Carolina State University

Raleigh, NC 27695 
This report was prepared by the Research Triangle Institute (RTI) as an account of work sponsored by the U.S. Department of Energy. RTI makes no warranty or representation, expressed or implied, with respect to the information contained in this report, or that the use of any apparatus, method or process disclosed in this report may not infringe privately owned rights. Furthermore, RTI assumes no liability with respect to the use of, or for damages resulting from the use of, any information, apparatus, method, or process disclosed in this report. 


\title{
Engineering Evaluation of Hot-Gas Desulfurization with Sulfur Recovery
}

\section{Topical Report}

Work performed under

Contract No. DE-AC21-94MC31258

for

U.S. Department of Energy

Federal Energy Technology Center

3610 Collins Ferry Road

Morgantown, WV 26505

\author{
by \\ S.K. Gangwal \\ J.W. Portzer \\ Research Triangle Institute \\ 3040 Cornwallis Road \\ Research Triangle Park, NC 27709 \\ and \\ G.W. Roberts \\ S.C. Kozup \\ Chemical Engineering Department \\ North Carolina State University \\ Raleigh, NC 27695
}

May 1998 


\begin{abstract}
Engineering evaluations and economic comparisons of two hot-gas desulfurization (HGD) processes with elemental sulfur recovery, being developed by Research Triangle Institute, are presented. In the first process, known as the Direct Sulfur Recovery Process (DSRP), the $\mathrm{SO}_{2}$ tail gas from air regeneration of zinc-based HGD sorbent is catalytically reduced to elemental sulfur with high selectivity using a small slipstream of coal gas. DSRP is a highly efficient firstgeneration process, promising sulfur recoveries as high as $99 \%$ in a single reaction stage. In the second process, known as the Advanced Hot Gas Process (AHGP), the zinc-based HGD sorbent is modified with iron so that the iron portion of the sorbent can be regenerated using $\mathrm{SO}_{2}$. This is followed by air regeneration to fully regenerate the sorbent and provide the required $\mathrm{SO}_{2}$ for iron regeneration. This second-generation process uses less coal gas than DSRP. Commercial embodiments of both processes were developed. Process simulations with mass and energy balances were conducted using ASPEN Plus. Results show that AHGP is a more complex process to operate and may require more labor cost than the DSRP. Also capital costs for the AHGP are higher than those for the DSRP.
\end{abstract}

However, annual operating costs for the AHGP appear to be considerably less than those for the DSRP with a potential break-even point between the two processes after just 2 years of operation for an integrated gasification combined cycle (IGCC) power plant using 3 to $5 \mathrm{wt} \%$ sulfur coal. Thus, despite its complexity, the potential savings with the AHGP encourage further development and scaleup of this advanced process. 


\section{TABLE OF CONTENTS}

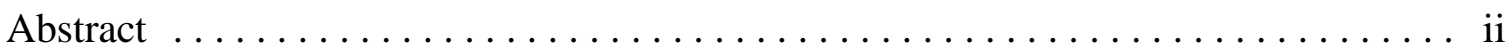

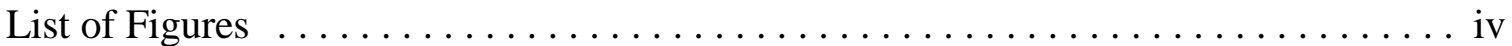

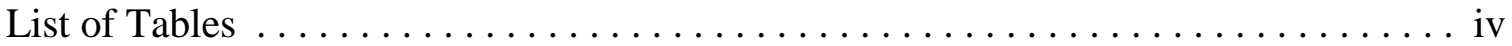

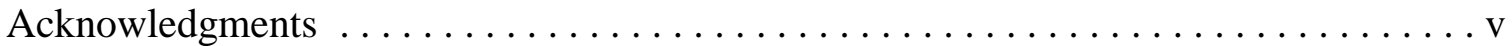

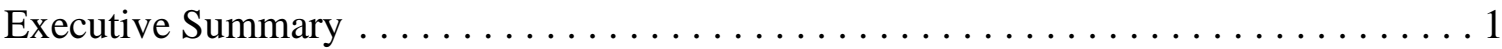

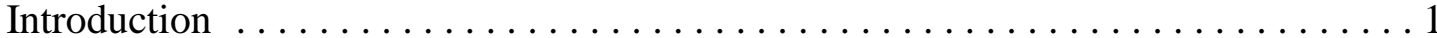

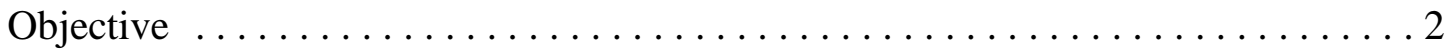

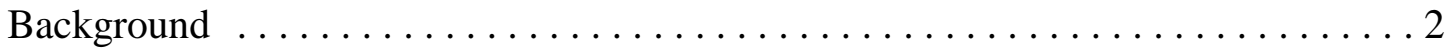

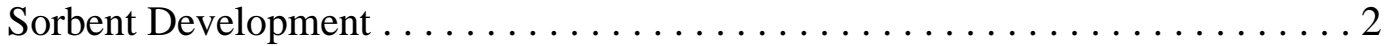

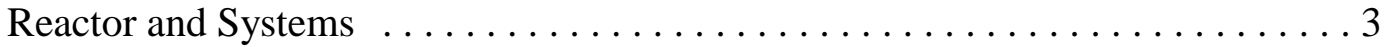

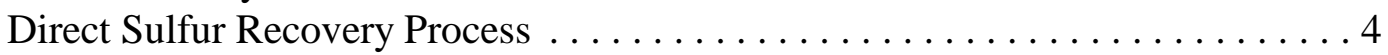

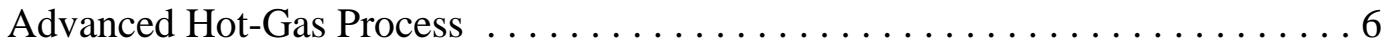

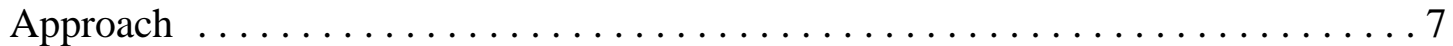

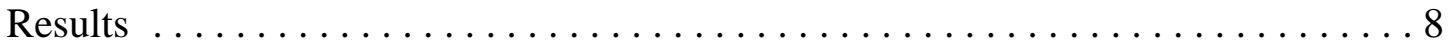

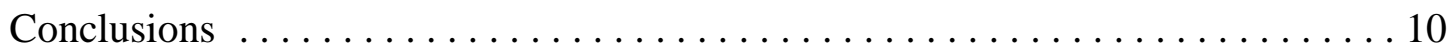

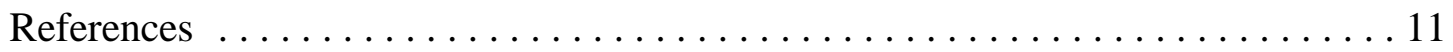

Appendix_-Process Modeling of Hot-Gas Desulfurization 


\section{LIST OF FIGURES}

Figure

Page

E-1

Advanced IGCC system . . . . . . . . . . . . . . . . . . 1

E-2

Schematic of Sierra hot-gas desulfurization system $\ldots \ldots \ldots \ldots \ldots \ldots$

E-3

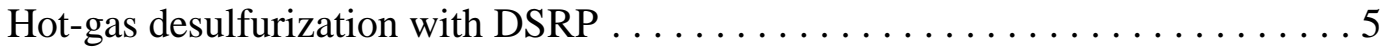

E-4

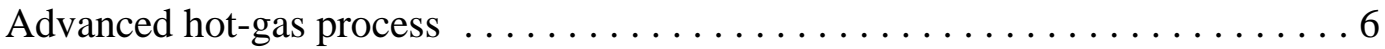

E-5

Schematic of AHGP desulfurization and regeneration reactors $\ldots \ldots \ldots \ldots 9$

E-6

Comparison of key elements of DSRP and AHGP . . . . . . . . . . 9

E-7

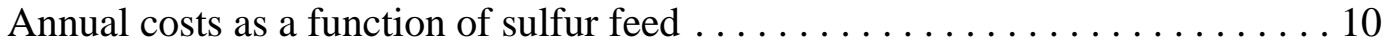

E-8

Cumulative HGD investment

10

\section{LIST OF TABLES}

Table

Page

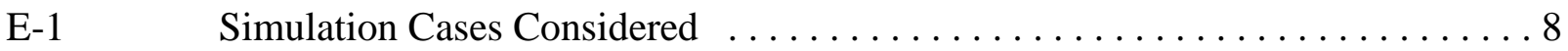

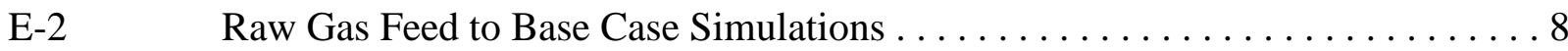




\section{ACKNOWLEDGMENTS}

This research was sponsored by the Federal Energy Technology Center of the U.S. Department of Energy. Valuable guidance and suggestions provided by the Contracting Officer's Representative, Mr. Thomas P. Dorchak, are sincerely acknowledged. 


\section{EXECUTIVE SUMMARY}

\section{INTRODUCTION}

Hot-gas desulfurization (HGD) of coal gas in integrated gasification combined cycle (IGCC) power systems has received a great deal of attention over the past two decades due to the potential for high thermal efficiency (up to 47\%) and low environmental impact of these advanced power systems. In an advanced IGCC system, coal is gasified at elevated pressures, typically 20 to $30 \mathrm{~atm}$, to produce a low-volume fuel gas which is desulfurized prior to burning in a combustion turbine to produce electricity. Higher efficiency and lower cost are achieved by efficient air and steam integration, and modular designs of the gasification, hot-gas cleanup, and turbine subsystems (Figure E-1). Hot gas cleanup primarily involves removal of particulates and sulfur-mostly hydrogen sulfide $\left(\mathrm{H}_{2} \mathrm{~S}\right)$ and some carbonyl sulfide $(\mathrm{COS}) . \mathrm{H}_{2} \mathrm{~S}$ and $\mathrm{COS}$ can be efficiently removed to less than $20 \mathrm{ppmv}$ at 350 to $650{ }^{\circ} \mathrm{C}$ using zinc-based metal oxide sorbents that can be regenerated for multicycle operation.

Air regeneration of these sorbents results in a dilute sulfur dioxide $\left(\mathrm{SO}_{2}\right)$-containing tail gas that needs to be disposed. Options include conversion of the $\mathrm{SO}_{2}$ to calcium sulfate using lime (or limestone) for landfilling or conversion to saleable products such as sulfuric acid or elemental sulfur. Elemental sulfur, an essential industrial commodity, is an attractive option because it is the lowest volume product and can be readily stored, disposed, transported, and/or sold.

Research Triangle Institute (RTI), with U.S. Department of Energy (DOE) sponsorship, is pursuing the development of two processes for elemental sulfur production in conjunction with

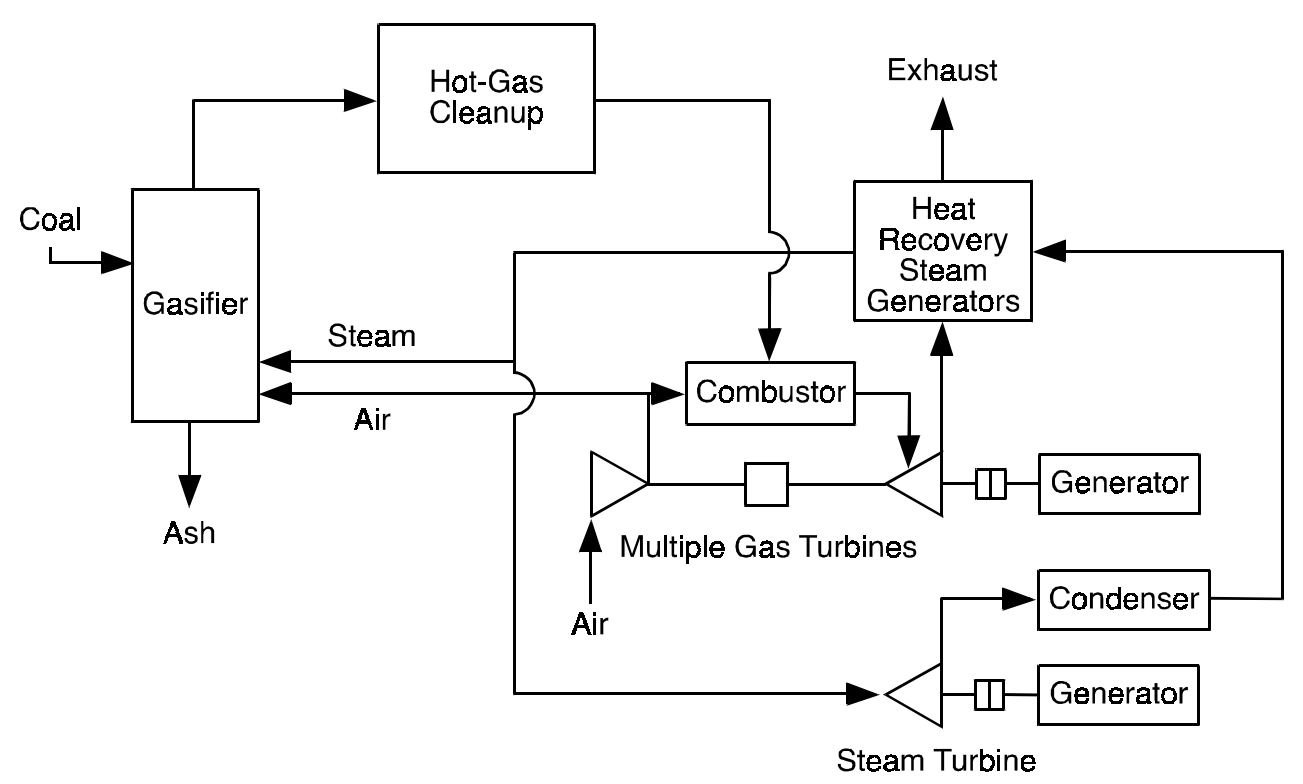

Figure E-1. Advanced IGCC system. 
hot-gas desulfurization. The first process, called the Direct Sulfur Recovery Process (DSRP), involves the selective catalytic reduction of the $\mathrm{SO}_{2}$ tail gas to sulfur using a small slipstream of the coal gas. DSRP is a highly efficient process that can recover up to $99 \%$ of $\mathrm{SO}_{2}$ as elemental sulfur in a single catalytic reactor. However, for every mole of sulfur produced two moles of hydrogen $\left(\mathrm{H}_{2}\right)$ and/or carbon monoxide $(\mathrm{CO})$ are consumed in DSRP and this represents an energy penalty for the IGCC plant. DSRP is currently in an advanced state of development.

A second-generation process being pursued by RTI involves the use of a modified zinc-based sorbent (containing zinc and iron). This sorbent can be regenerated using $\mathrm{SO}_{2}$ and $\mathrm{O}_{2}$ to directly produce sulfur. This process, called the Advanced Hot-Gas Process (AHGP), is expected to use much less coal gas than DSRP. DSRP is currently at the pilot-plant scale development stage, whereas AHGP has been demonstrated at small bench-scale. Both DSRP and AHGP are scheduled for slipstream testing at DOE's Power Systems Development Facility (PSDF), Wilsonville, Alabama, in 1999.

\section{OBJECTIVE}

The objective of this report is to develop process simulations with mass and heat balances for the DSRP and AHGP and to provide a preliminary economic comparison of the two processes in conjunction with an IGCC power plant employing HGD. The process simulation and economic evaluation were carried out by RTI's subcontractor, North Carolina State University (NCSU). NCSU's report of this work in its entirety is attached as an appendix. Background, brief process description, and important results and conclusions are provided below as a stand-alone executive summary.

\section{BACKGROUND}

\section{Sorbent Development}

Research on HGD methods for coal gas in IGCC systems has concentrated on the use of regenerable metal oxide sorbents (Gangwal, 1991, 1996; Gangwal et al., 1993, 1995; Harrison, 1995; Jalan, 1985; Thambimuthu, 1993). This research and development effort has been spearheaded by DOE's Federal Energy Technology Center (FETC) and its predecessor agencies since 1975.

The HGD process using a regenerable metal oxide (MO) sorbent is typically carried out in a tworeactor system consisting of a desulfurizer and an air regenerator

$$
\begin{array}{cc}
\mathrm{MO}+\mathrm{H}_{2} \mathrm{~S} \rightarrow \mathrm{MS}+\mathrm{H}_{2} \mathrm{O} & \text { (desulfurizer) } \\
\mathrm{MS}+(3 / 2) \mathrm{O}_{2} \rightarrow \mathrm{MO}+\mathrm{SO}_{2} & \text { (regenerator) }
\end{array}
$$

The main requirement of the metal oxide sorbent is that it should selectively react with $\mathrm{H}_{2} \mathrm{~S}$ and $\mathrm{COS}$ in a reducing fuel gas at desired conditions ( 2 to $3 \mathrm{Mpa}, 350$ to $750{ }^{\circ} \mathrm{C}$ ). The thermodynamics of the reaction should be favorable enough to achieve the desired level of $\mathrm{H}_{2} \mathrm{~S}$ and COS removal (as much as $99 \%$ or more). The metal oxide should be stable in the reducing gas environment, i.e., reduction of MO to M should be slow or thermodynamically unfavorable since 
it leads to loss of valuable fuel gas and could also lead to volatile metal evaporation and decrepitation of sorbent structure.

The principle requirement during air regeneration is that the sorbent should predominantly revert back to its oxide rather than to sulfate $\left(\mathrm{MO}+\mathrm{SO}_{2}+1 / 2 \mathrm{O}_{2} \rightarrow \mathrm{MSO}_{4}\right)$. Air regeneration is highly exothermic and requires tight temperature control using large quantities of diluent $\left(\mathrm{N}_{2}\right)$ or other means to prevent sorbent sintering and sulfate formation.

The bulk of research on regenerable sorbents has been on zinc-based sorbents because sorbents based on zinc oxide appear to have the fewest technical problems among all sorbents. Zinc oxide ( $\mathrm{ZnO})$ has highly attractive thermodynamics for $\mathrm{H}_{2} \mathrm{~S}$ adsorption and can reduce the $\mathrm{H}_{2} \mathrm{~S}$ to partsper-million levels over a very wide temperature range. Iron oxide appears to be the most popular sorbent for use at around $400{ }^{\circ} \mathrm{C}$.

A combined $\mathrm{ZnO}$-iron oxide $\left(\mathrm{Fe}_{2} \mathrm{O}_{3}\right)$ sorbent, namely, zinc ferrite $\left(\mathrm{ZnFe}_{2} \mathrm{O}_{4}\right)$ was developed by Grindley and Steinfeld (1981) to combine the advantages of $\mathrm{ZnO}$ and $\mathrm{Fe}_{2} \mathrm{O}_{3}$. A temperature range of 550 to $750{ }^{\circ} \mathrm{C}$ received the major research emphasis in the United States during the 1980 s and early 1990s. Because of zinc oxide's potential for reduction $\left(\mathrm{ZnO}+\mathrm{H}_{2} \rightarrow \mathrm{Zn}+\mathrm{H}_{2} \mathrm{O}\right)$ at $>600{ }^{\circ} \mathrm{C}$ followed by evaporation, a zinc oxide-titanium oxide sorbent, namely zinc titanate sorbent, was developed and tested at high temperature and high pressure (HTHP) (Gangwal et al., 1988). Zinc titanate is currently one of the leading sorbents.

During recent years, research emphasis has shifted toward lower temperatures (350 to $550{ }^{\circ} \mathrm{C}$ ) based on a study in the Netherlands (NOVEM, 1991). According to this study, the thermal efficiency of an 800-MWe IGCC plant increased from $42.75 \%$ using cold-gas cleanup to $45.14 \%$ using HGD at $350{ }^{\circ} \mathrm{C}$ and to $45.46 \%$ using HGD at $600{ }^{\circ} \mathrm{C}$. The small efficiency increase from 350 to $600{ }^{\circ} \mathrm{C}$ suggested that temperature severity of HGD could be significantly reduced without much loss of efficiency.

\section{Reactor and Systems}

A two-reactor configuration is necessary for HGD due to its cyclic nature. Early developments emphasized fixed beds. The highly exothermic regeneration led to a move away from fixed beds toward moving beds (Ayala et al., 1995; Cook et al., 1992) and fluidized beds (Gupta and Gangwal, 1992). Two DOE Clean Coal Technology IGCC demonstration plants, namely TECO and Sierra-Pacific, employing General Electric's (GE's) moving-bed HGD reactor system and M.W. Kellogg's transport reactor HGD system, respectively, are scheduled to begin operation this year. Fluidized-bed HGD systems are receiving a lot of emphasis due to several potential advantages over fixed- and moving-bed reactors, including excellent gas-solid contact, fast kinetics, pneumatic transport, ability to handle particles in gas, and ability to control the highly exothermic regeneration process. However, an attrition-resistant sorbent that can withstand stresses induced by fluidization, transport, chemical transformation, and rapid temperature swings must be developed.

Development of an iron-oxide sorbent-based fluidized-bed HGD reactor system has been carried out in Japan over the past several years (Sugitani, 1989). The process is now up to 200 tons of 
coal per day. The sorbent is prepared by crushing raw Australian iron oxide which is inexpensive, but attrition is a big problem with this sorbent. Durable zinc titanate and other zinc-based sorbent development is ongoing for application at the Sierra-Pacific plant for Kellogg's transport reactor (Gupta et al., 1996, 1997; Jothimurugesan et al., 1997; Khare et al., 1996).

A schematic of Kellogg's transport reactor system at Sierra-Pacific is shown in Figure E-2. This technology represents a significant development in HGD because it allows regeneration with neat air. Neat air regeneration produces a more concentrated $\mathrm{SO}_{2}$ tail-gas stream containing around 14 $\operatorname{vol} \% \mathrm{SO}_{2}$.

The initial sorbent tested at Sierra-Pacific was Phillips Z-Sorb III. Its attrition resistance was not acceptable. Phillips is continuing efforts to improve their sorbent. Recently RTI and Intercat have provided a much more attrition-resistant zinc titanate sorbent, EX-SO3, to Sierra-Pacific for testing after qualifying it through a series of bench- and process development unit (PDU)-scale tests (Gupta et al., 1997). This sorbent has been circulated in the system and has demonstrated satisfactory attrition resistance. Chemical reactivity tests with the sorbent are to be conducted shortly after the Sierra coal gasifier is fully commissioned and begins smooth operation.

\section{Direct Sulfur Recovery Process}

The patented DSRP being developed by RTI is a highly attractive option for recovery of sulfur from regeneration tail gas. Using a slipstream of coal gas as a reducing agent, it efficiently converts the $\mathrm{SO}_{2}$ to elemental sulfur, an essential industrial commodity that is easily stored and transported. In the DSRP (Dorchak et al., 1991), the $\mathrm{SO}_{2}$ tail gas is reacted with a slipstream of coal gas over a fixed bed of a selective catalyst to directly produce elemental sulfur at the HTHP conditions of the tail gas and coal gas. Overall reactions involved are shown below:

$$
\begin{gathered}
2 \mathrm{H}_{2}+\mathrm{SO}_{2} \rightarrow(1 / n) \mathrm{S}_{\mathrm{n}}+2 \mathrm{H}_{2} \mathrm{O} \\
2 \mathrm{CO}+\mathrm{SO}_{2} \rightarrow(1 / \mathrm{n}) \mathrm{S}_{\mathrm{n}}+2 \mathrm{CO}_{2} \\
\mathrm{CO}+\mathrm{H}_{2} \mathrm{O} \rightarrow \mathrm{H}_{2}+\mathrm{CO}_{2} \\
\mathrm{H}_{2}+(1 / \mathrm{n}) \mathrm{S}_{\mathrm{n}} \rightarrow \mathrm{H}_{2} \mathrm{~S} \\
2 \mathrm{H}_{2} \mathrm{~S}+\mathrm{SO}_{2} \rightarrow(3 / \mathrm{n}) \mathrm{S}_{\mathrm{n}}+2 \mathrm{H}_{2} \mathrm{O} .
\end{gathered}
$$

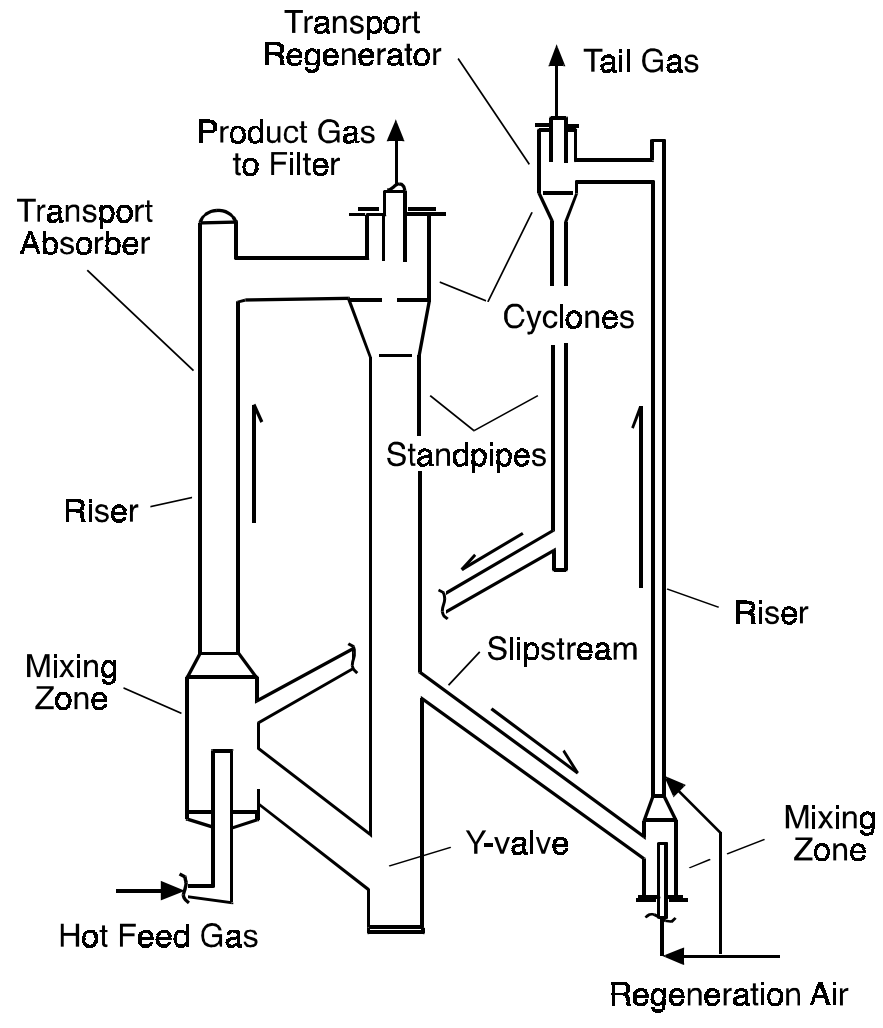

Figure E-2. Schematic of Sierra hot-gas desulfurization system. 
RTI constructed and commissioned a mobile laboratory for DSRP demonstration with actual coal gas from the DOE-Morgantown coal gasifier. Slipstream testing using a 1-L fixed-bed of DSRP catalyst with actual coal gas (Portzer and Gangwal, 1995; Portzer et al., 1996) demonstrated that, with careful control of the stoichiometric ratio of the gas input, sulfur recovery of $96 \%$ to $98 \%$ can be consistently achieved in a single DSRP stage. The single-stage process, as it is proposed to be integrated with a metal oxide sorbent regenerator, is shown in Figure E-3. With the tail-gas recycle stream shown in the figure, there are no sulfur emissions from the DSRP. RTI also demonstrated the ruggedness of the DSRP catalyst by exposing it to coal gas for over 250 hours in a canister test.

The results show that, after a significant exposure time to actual coal gas, the DSRP catalyst continues to function in a highly efficient manner to convert $\mathrm{SO}_{2}$ in a simulated regeneration tail gas to elemental sulfur. This demonstration of a rugged, single-stage catalytic process resulted in additional online experience and the assembling of more process engineering data. The development of the DSRP continues to look favorable as a feasible commercial process for the production of elemental sulfur from hot-gas desulfurizer regeneration tail gas.

Canisters of fixed-bed DSRP catalyst have been prepared for another exposure test with actual coal gas, this time at FETC's PSDF at Wilsonville, Alabama. Exposure is expected to take place sometime during FY 2000.

Additional development and testing of a fluidized-bed process is planned, capable of producing elemental sulfur from 14 vol\% $\mathrm{SO}_{2}$ at HTHP. These tests intend to demonstrate the use of DSRP in conjunction with the Kellogg transport regenerator producing $14 \mathrm{vol} \% \mathrm{SO}_{2}$. Due to the exothermic nature of the DSRP reactions, a fluidized-bed reactor is a preferred configuration at these high $\mathrm{SO}_{2}$ concentrations. Two candidate attrition-resistant fluidizable DSRP catalysts have been prepared in cooperation with a catalyst manufacturer. A series of tests was conducted using these catalysts with up to $14 \mathrm{vol} \% \mathrm{SO}_{2}$ tail gas, at pressures from 1.0 to $2.0 \mathrm{Mpa}$, temperatures

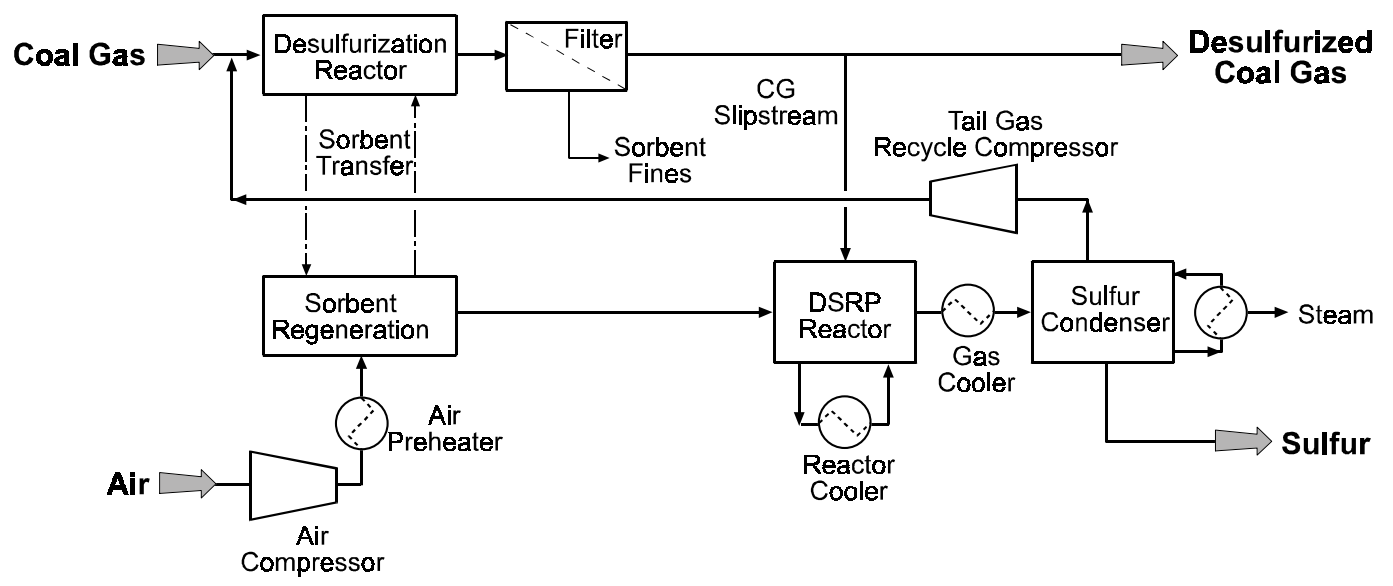

Figure E-3. Hot-gas desulfurization with DSRP. 
from 500 to $600{ }^{\circ} \mathrm{C}$, and space velocities from 3,000 to $6,000 \mathrm{stdcm}^{3} / \mathrm{cm}^{3}$. Sulfur recoveries up to $98.5 \%$ were achieved during steady-state operation, and no attrition of the catalyst occurred in the fluidized-bed tests.

Planning is underway to conduct a long-duration field test using a skid-mounted six-fold larger (based on reactor volume) (6X) DSRP unit with a slipstream of actual coal gas at PSDF. The mobile laboratory will be refitted at RTI as a control room for the $6 \mathrm{X}$ unit and will be moved along with the skid-mounted $6 \mathrm{X}$ unit to Wilsonville, Alabama, for the testing to be conducted in FY 2000. This larger unit will utilize a fluidized-bed reactor and will be designed for production of up to 22 times more sulfur than the 7.5-cm I.D. bench-scale unit used in the previous slipstream tests.

\section{Advanced Hot-Gas Process}

In the DSRP, for every mole of $\mathrm{SO}_{2}, 2$ mol of reducing components are used, leading to a small but noticeable consumption of coal gas. Novel regeneration processes that could lead to elemental sulfur without use of coal gas or with limited use of coal gas are being developed (Gangwal et al., 1996; Harrison et al. 1996). KEMA's hot-gas cleanup process (Meijer et al., 1996) uses a proprietary fluidized-bed sorbent which can remove $\mathrm{H}_{2} \mathrm{~S}$ to below $20 \mathrm{ppmv}$ and can be regenerated using $\mathrm{SO}_{2}, \mathrm{O}_{2}$ mixtures to directly produce elemental sulfur. Along similar lines, a second-generation process, known as the Advanced Hot-Gas Process (AHGP), is being developed by RTI to regenerate the desulfurization sorbent directly to elemental sulfur with minimal consumption of coal gas. In this process (Figure E-4), a zinc-iron sorbent is used and the regeneration is carried out in two stages with $\mathrm{SO}_{2}$ and $\mathrm{O}_{2}$, respectively. The iron sulfide is regenerated by $\mathrm{SO}_{2}$ in one stage to elemental sulfur. In the other stage, zinc sulfide and any remaining iron sulfide are regenerated by $\mathrm{O}_{2}$ to provide the required $\mathrm{SO}_{2}$. The sorbent is then returned to the desulfurizer.

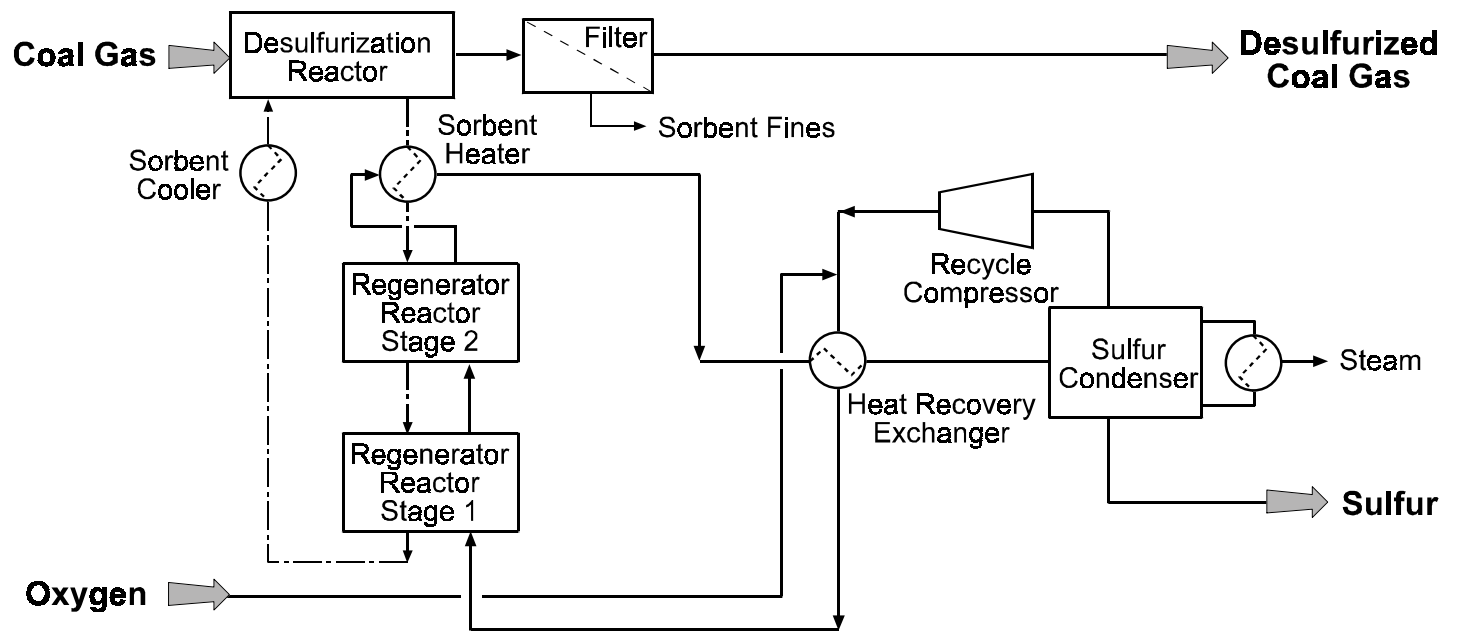

Figure E-4. Advanced hot-gas process. 
The key chemical reactions of interest are as follows:

1. Sulfidation

$$
\begin{gathered}
\mathrm{Fe}_{2} \mathrm{O}_{3}+2 \mathrm{H}_{2} \mathrm{~S}+\mathrm{H}_{2} \rightarrow 2 \mathrm{FeS}+3 \mathrm{H}_{2} \mathrm{O} \\
\mathrm{ZnO}+\mathrm{H}_{2} \mathrm{~S} \rightarrow \mathrm{ZnS}+\mathrm{H}_{2} \mathrm{O}
\end{gathered}
$$

2. $\mathrm{SO}_{2}$ regeneration

$$
4 \mathrm{FeS}+3 \mathrm{SO}_{2} \rightarrow 2 \mathrm{Fe}_{2} \mathrm{O}_{3}+7 / 2 \mathrm{~S}_{2}
$$

3. $\mathrm{O}_{2}$ regeneration

$$
\begin{gathered}
2 \mathrm{FeS}+7 / 2 \mathrm{O}_{2} \rightarrow \mathrm{Fe}_{2} \mathrm{O}_{3}+2 \mathrm{SO}_{2} \\
\mathrm{ZnS}+3 / 2 \mathrm{O}_{2} \rightarrow \mathrm{ZnO}+\mathrm{SO}_{2} .
\end{gathered}
$$

The feasibility of $\mathrm{SO}_{2}$ regeneration of combined zinc-iron sorbents was demonstrated using a thermogravimetric analyzer and high-pressure microreactor. Zinc sulfide shows essentially no $\mathrm{SO}_{2}$ regeneration at temperatures of interest $\left(500\right.$ to $\left.600{ }^{\circ} \mathrm{C}\right)$, but zinc is needed to act as a polishing agent in the desulfurizer. A number of sorbents were prepared and tested at the bench scale over multiple cycles. Based on these tests, a highly attrition-resistant sorbent (R-5-58) was prepared and the process was demonstrated over 50 cycles in a 5.0-cm I.D. bench-scale reactor.

The results showed that $\mathrm{R}-5-58$ removed $\mathrm{H}_{2} \mathrm{~S}$ down to 50 to 100 ppm levels with stable desulfurization activity over the duration. The surface area and pore volume of the sorbent did not change appreciably and the attrition index before and after the test was $3.6 \%$ and $1.2 \%$, respectively. Sulfur balances were adequate and the $\mathrm{SO}_{2}$ regeneration step accounted for up to $70 \%$ of the total regeneration of the sorbent. This compares to a theoretical limit of approximately $80 \%$, assuming complete regeneration by $\mathrm{SO}_{2}$ of the iron component.

The sorbent is being optimized further to increase its desulfurization efficiency. The goal is to develop a sorbent that can remove $\mathrm{H}_{2} \mathrm{~S}$ below 20 ppmv. Plans call for demonstrating the process at PSDF with a slipstream of actual coal gas in FY 1999 in conjunction with the DSRP field test at PDSF.

\section{APPROACH}

An engineering and economic evaluation of the DSRP (Figure E-3) and AHGP (Figure E-4) for large-scale IGCC plants was conducted using ASPEN PLUS ${ }^{\circledR}$ computer process simulation software by NCSU. The NCSU report is attached in its entirety as an appendix. Here we present a summary of the approach, key results, and conclusions.

Base case simulations of both processes assumed $0.85 \mathrm{~mol} \% \mathrm{H}_{2} \mathrm{~S}$ in the coal-gas feed. Such an $\mathrm{H}_{2} \mathrm{~S}$ concentration in the coal gas would be produced by an oxygen-blown Texaco gasification using roughly a $3.6 \mathrm{wt} \%$ sulfur-containing coal. Both base cases generate $260 \mathrm{MWe}$ from the clean coal gas. Simulations that deviate from the base cases use suffixes to denote the changes. Table E-1 displays the significance of the suffixes. In all cases a coal-gas feed pressure and 
temperature of $275 \mathrm{psia}$ and $482{ }^{\circ} \mathrm{C}$, respectively, was used. However, $\mathrm{H}_{2} \mathrm{~S}$ concentration was varied from 0.25 to $2.5 \mathrm{~mol} \%$ and power produced was varied from 110 to $540 \mathrm{MWe}$. Table E-2 shows the composition and flow rate of the raw coal gas feed to the base case HGD processes. The requirement of a higher amount of coal gas to produce the same $260 \mathrm{MW}$ power by DSRP versus the AHGP is noteworthy. The DSRP was assumed to use the standard Sierra-Pacific dual transport reactor configuration shown in Figure E-2 for HGD. The DSRP reactor used for the $14 \%$ SO2 tail gas was a fast fluidized bed with an alumina-based catalyst. The AHGP reactor configuration on the other hand used a transport sulfider and a bubbling multistage fluidized-bed regenerator as shown in Figure E-5. The large bubbling reactor was required to provide a greater residence time for the slow $\mathrm{SO}_{2}$ regeneration stage.

\section{RESULTS}

The preliminary process and economic evaluations conducted using ASPEN Plus are summarized. Figure E-6 compares key elements using a simple method in which each parameter for the DSRP-based process is arbitrarily assigned the value of 1.0. A range of values is produced for AHGP to cover the various cases being considered. The big advantage of the AHGP is clearly the reduced parasitic consumption of coal gas. The other operating cost elements are also lower for AHGP, because that process has a considerably lower compression power requirement. A desulfurization process based on the DSRP requires a large flow of compressed air to provide the oxygen necessary to regenerate the sulfided sorbent, and thus has a large compressor horsepower duty. By comparison, the AHGP uses oxygen only for a smaller, polishing regeneration and, by using pure oxygen, the compression duty is lowered further. The AHGP also has the $\mathrm{SO}_{2}$ loop recycle compressor, but its duty is quite small compared to the DSRP air compressor.
Table E-1. Simulation Cases Considered

\begin{tabular}{lcc}
\hline \multicolumn{1}{c}{ Simulations } & $\begin{array}{c}\mathbf{H}_{\mathbf{2}} \mathbf{S} \text { feed } \\
\text { concentration } \\
\text { (mol\%) }\end{array}$ & $\begin{array}{c}\text { MW } \\
\text { produced }\end{array}$ \\
\hline $\begin{array}{l}\text { DSRP, AHGP } \\
\text { (base cases) }\end{array}$ & 0.85 & 260 \\
DSRP-b, & 2.50 & 260 \\
AHGP-b & 0.25 & 260 \\
DSRP-c, & & \\
AHGP-C & 0.85 & 110 \\
DSRP-100, & & \\
AHGP-100 & 0.85 & 540 \\
DSRP-500, & & \\
AHGP-500 & & \\
\hline
\end{tabular}

Table E-2. Raw Gas Feed to Base Case Simulations

\begin{tabular}{crc}
\hline Component & DSRP $(\mathbf{I b} / \mathbf{h})$ & AHGP $(\mathbf{l b} / \mathbf{h})$ \\
\hline $\mathrm{H}_{2} \mathrm{~S}$ & 6,300 & 6,100 \\
$\mathrm{H}_{2} \mathrm{O}$ & 70,500 & 69,000 \\
$\mathrm{H}_{2}$ & 11,800 & 11,500 \\
$\mathrm{CO}$ & 218,200 & 213,400 \\
$\mathrm{CO}_{2}$ & 117,400 & 114,800 \\
$\mathrm{~N}_{2}$ & 36,300 & 35,500 \\
Total & 460,500 & 450,300 \\
\hline
\end{tabular}


[It should be noted that in the NCSU economic analysis (Appendix) the AHGP recycle compressor duty may be understated, as the calculation was based on a rough estimate for pressure drop, not a calculated value based on a piping design. By comparison, the duty for the DSRP air compressor is primarily a function of the head pressure of the system, which is well defined.]

The value of "capital cost of all equipment" for the AHGP is higher than for the DSRP-based process, as Figure E-5 shows. The higher equipment cost is primarily due to the higher cost of the AHGP reactor vessel(s). Although there are three separate reactor steps required with the DSRP-based process, the single AHGP multistage reactor vessel(s) is larger. The larger size is primarily due to the longer residence time required for the $\mathrm{SO}_{2}$ regeneration. [It should be noted that the NCSU cost estimates (Appendix) do not include piping costs, so that the total plant capital costs will be higher than the installed equipment costs. However, since piping costs are often estimated as a direct function of the equipment cost numbers, the ratio of the installed equipment costs for the two processes shown in the figure will approximate the ratio of the total plant costs.]

Another advantage of the DSRP is that it is the easier, more understood, process to operate. This is because balancing the $\mathrm{SO}_{2}$ production and consumption in the AHGP may be difficult.

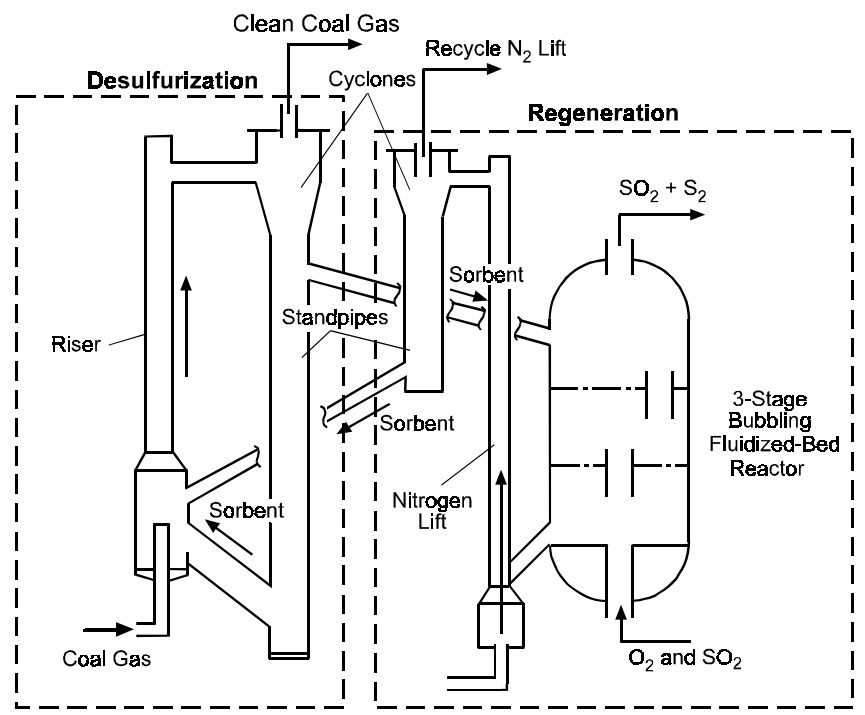

Figure E-5. Schematic of AHGP desulfurization and regeneration reactors.

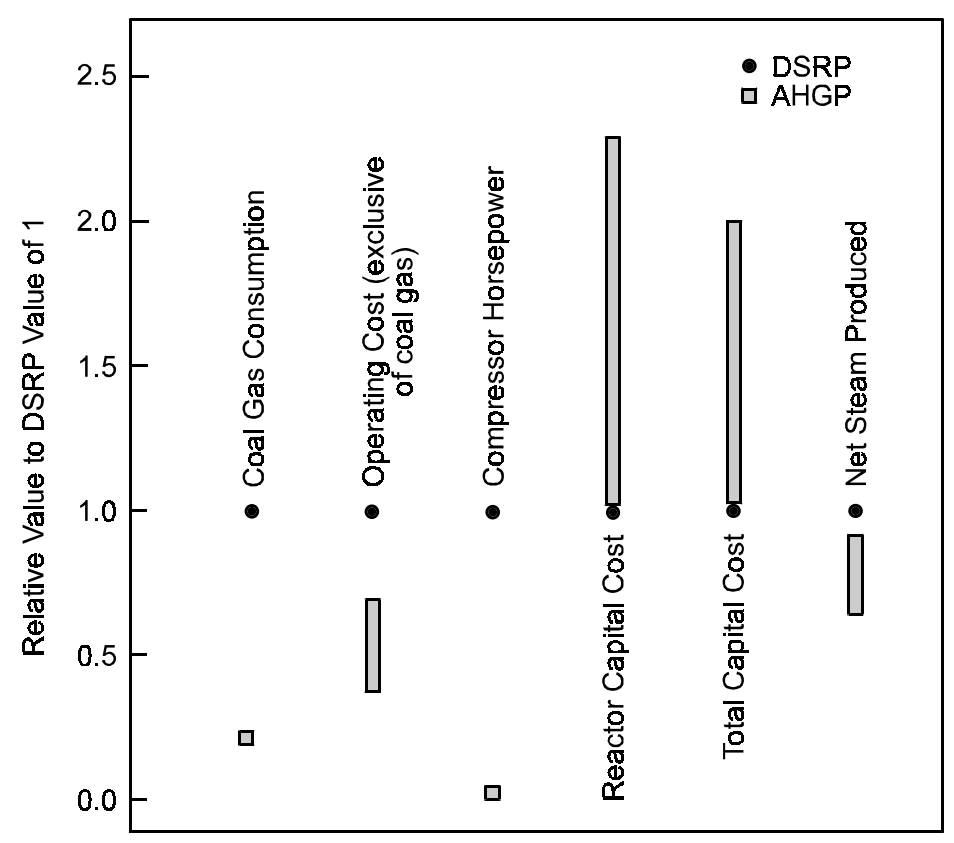

Figure E-6. Comparison of key elements of DSRP and AHGP. 
Although the AHGP has a higher initial cost, indicated by its larger capital requirements, it has a significantly lower annual operating cost than DSRP. As shown in Figure E-7, the operating cost advantage of the AHGP increases as the sulfur to be recovered increases. The negative annual costs of AHGP at higher sulfur feed result from the sulfur credit with less consumption of coal gas. The operating cost difference is large enough to offset the installation cost of AHGP. As shown in Figure E-8, AHGP has a lower cumulative HGD investment after only 2 years of operation. Both Figures E-7 and E-8 are presented to illustrate only cost comparison of the two processes. Emphasis should not be placed on the accuracy of the absolute cost numbers presented in these figures.

\section{CONCLUSIONS}

ASPEN simulations of DSRP and AHGP revealed the complexity of both HGD processes. The AHGP appears to be the more difficult process to operate and may require more employees than

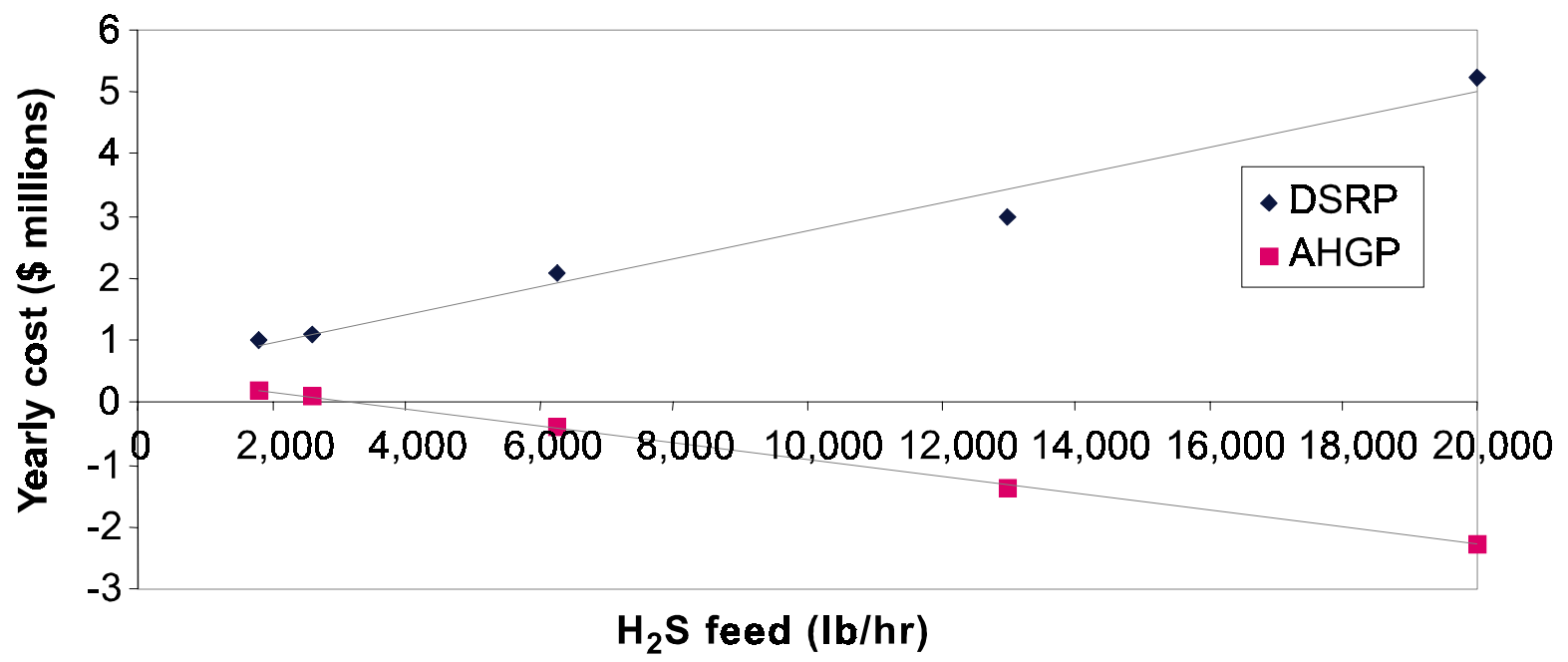

Figure E-7. Annual costs as a function of sulfur feed.

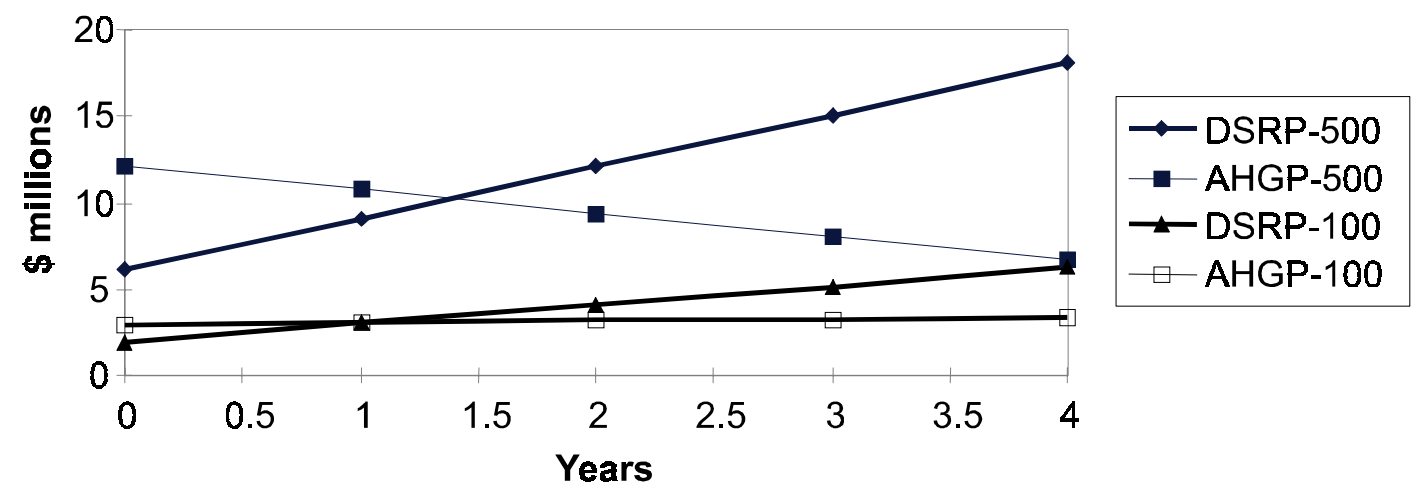

Figure E-8. Cumulative HGD investment. 
the DSRP. Capital costs for the AHGP are higher than those for the DSRP-development of DSRP is also much closer to commercialization than AHGP. However, annual operating costs for the AHGP appear to be considerably less than those of the DSRP. Preliminary economic comparison shows that the total cost of implementing AHGP will be less than that of implementing DSRP after as little as 2 years of operation. Thus, despite its greater complexity, the potential savings with the AHGP encourage further development and scaleup of this advanced process.

\section{REFERENCES}

Ayala, R.E., A.S. Feitelberg, and A.H. Furman. 1995. "Development of a High-Temperature Moving-Bed Coal Gas Desulfurization System." In Proceedings of 12th Ann. Int. Pittsburgh Coal Conf., p. 1053, September 11-15, Pittsburgh.

Cook, C.S., et al. 1992. "Integrated Operation of a Pressurized Fixed Bed Gasifier and Hot Gas Desulfurization System.” In Proceedings of 12th Annual Gasif. Gas Stream Cleanup Systems Contractor's Review Meeting, Volume 1, DE93000228, p. 84.

Dorchak, T.P., S.K. Gangwal, and W.J. McMichael. 1991. The Direct Sulfur Recovery Process. Environmental Progress 19(2):68.

Gangwal, S.K. 1991. "Hot-Gas Desulfurization Sorbent Development for IGCC Systems." IChemE Symposium Series No. 123. Sheffield, UK, pp. 159-170.

Gangwal, S.K. 1996. "Sulfur Removal from Gas Streams at High Temperature," 3rd International Symposium on Gas Cleaning at High Temperature. University of Karlsruhe, Karlsruhe, Germany, September.

Gangwal, S.K., et al. 1988. "Bench-Scale Testing of Novel High-Temperature Desulfurization Sorbents.” Report No. DOE/MC/23126-2662 (DE89000935).

Gangwal, S.K., R. Gupta, and W.J. McMichael. 1993. "Sulfur Control Options for IGCC Systems." In Proceedings of 17th Biennial Low-Rank Fuels Symposium, University of North Dakota, Energy and Environmental Research Center, St. Louis, MO, May 10-13.

Gangwal, S.K., R. Gupta, and W.J. McMichael. 1995. "Hot-Gas Cleanup-Sulfur RecoveryTechnical, Environmental, and Economic Issues," Heat Recovery Systems and CHP. Vol. 15, No. 2, p. 205-214, Elsevier Science Limited.

Grindley, T., and G. Steinfeld. 1981. "Development and Testing of Regenerable Hot Coal-Gas Desulfurization Sorbents.” DOE/MC/16545-1125.

Gupta, R., and S.K. Gangwal. 1992. "Enhanced Durability of Desulfurization Sorbents for Fluidized Bed Applications_-Development and Testing of Zinc Titanate Sorbents." DOE/MC/25006-3271. 
Gupta, R., B.S. Turk, and S.K. Gangwal. 1996. "Bench-Scale Development of Fluid-Bed Spray Dried Sorbents." In Proceedings of Advanced Coal-Fired Power Systems '96 Review Meeting, Morgantown Energy Technology Center, Morgantown, WV, July.

Gupta, R., B.S. Turk, and Albert A. Vierheilig. 1997. "Desulfurization Sorbents for TransportBed Applications." In Proceedings of 1997 FETC Power Systems and Environmental Control Contractor's Meeting, Pittsburgh, PA, July.

Harrison, D.P. 1995. "Control of Gaseous Contaminants in IGCC Processes, An Overview," In Proceedings of 12th Ann. Int. Pittsburgh Coal Conference, p. 1047, September 11-15, Pittsburgh.

Harrison, D.P., F.R. Groves, J.D. White, W. Huang, and A. Lopez-Oritz. 1996. "Advanced Sulfur Control Processing." In Proceedings of Advanced Coal-Fired Power Systems '96 Review Meeting, Morgantown Energy Technology Center, Morgantown, WV, July.

Jalan, V. 1985. "High-Temperature Desulfurization of Coal Gases." In Acid and Sour Gas Treating Processes, Gulf Publishing Co., Houston, TX, Nov. 7.

Jothimurugesan, K., S.K. Gangwal, R. Gupta, and B.S. Turk. 1997. “Advanced Hot-Gas Desulfurization Sorbents." In Proceedings of 1997 FETC Power Systems and Environmental Control Contractor's Meeting, Pittsburgh, PA, July.

Khare, G.P., G.A. Delzer, G.J. Greenwood, and D.H. Kunbicek. 1996. "Phillips Sorbent Development for Tampa Electric and Sierra Pacific." In Proceedings of Advanced Coal-Fired Power Systems '96 Review Meeting, Morgantown Energy Technology Center, Morgantown, WV, July.

Meijer, R., F.J.J.G. Janssen, G.L. Faring, and J.W. H. Hellendoorn. 1996. “KEMA’s Hot Gas Cleanup Process." In Proceedings of 3rd International Symposium on Gas Cleaning at High Temperature. University of Karlsruhe, Karlsruhe, Germany, September.

NOVEM. 1991. "System Study High Temperature Gas Cleaning at IGCC Systems.” Netherlands Agency for Energy and the Environment.

Portzer, J.W., and S.K. Gangwal. 1995. "Slipstream Testing of Hot Gas Desulfurization with Sulfur Recovery." In Proceedings of the Advanced Coal-Fired Power Systems '95 Review Meeting, pp. 220-228. DOE/METC-95/1018, Vol. 1, NTIS/DE 95009732. Springfield, VA: National Technical Information Service.

Portzer, J.W., B.S. Turk, and S.K. Gangwal. 1996. "Durability Testing of the Direct Sulfur Recovery Process." In Proceedings of the Advanced Coal-Fired Power Systems Review Meeting July 16 B18, 1996. (CD-ROM). U.S. Department of Energy. Morgantown, WV.

Sugitani, T. 1989. Development of Hot-Gas Desulfurization Process. Journal of the Fuel Society of Japan 68(9):787. 
Thambimuthu, K.V. 1993. Gas Cleaning for Advanced Coal-Based Power Generation. Report by IEA Coal Research, IEACR/53, London, UK. 


\title{
Appendix
}

\section{Process Modeling of Hot-Gas Desulfurization}

\author{
Steve C. Kozup \\ George W. Roberts \\ North Carolina State University
}




\section{TABLE OF CONTENTS}

\section{PAGE}

EXECUTIVE SUMMARY $\ldots \ldots \ldots \ldots \ldots \ldots \ldots \ldots \ldots \ldots \ldots \ldots \ldots \ldots \ldots \ldots$

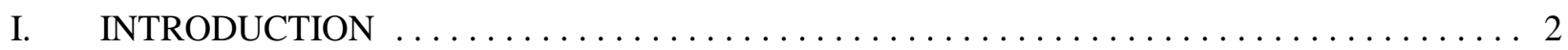

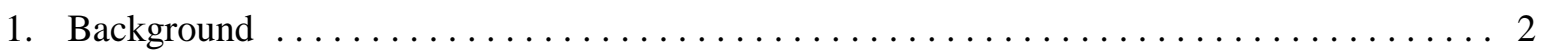

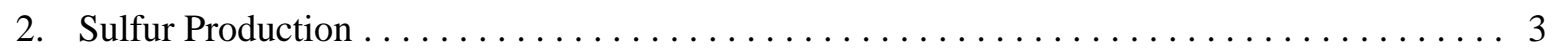

II. BASIC PROCESS DESCRIPTIONS $\ldots \ldots \ldots \ldots \ldots \ldots \ldots \ldots \ldots \ldots \ldots \ldots \ldots$

1. Direct Sulfur Recovery Process Sorbent Cycle $\ldots \ldots \ldots \ldots \ldots \ldots \ldots \ldots \ldots \ldots$

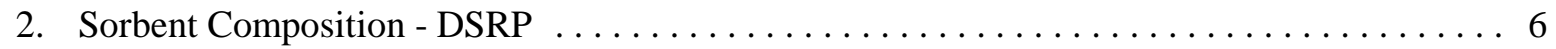

3. Advanced Hot Gas Process Sorbent Cycle $\ldots \ldots \ldots \ldots \ldots \ldots \ldots \ldots \ldots \ldots \ldots$

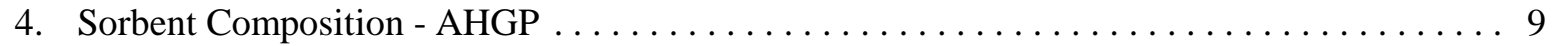

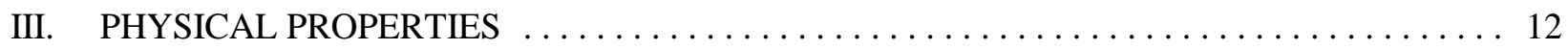

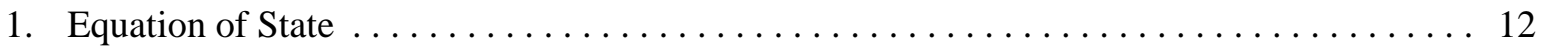

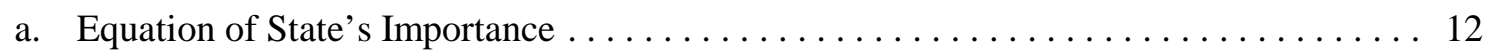

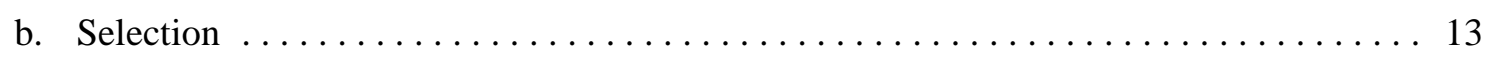

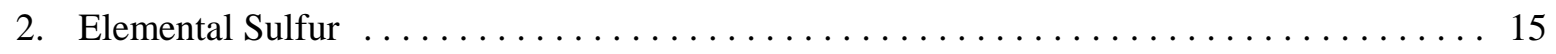

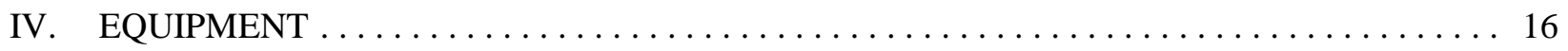

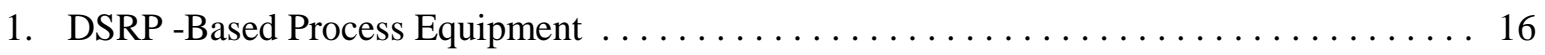

a. Desulfurization and Regeneration Transport Reactors - DSRP . . . . . . . . . 16

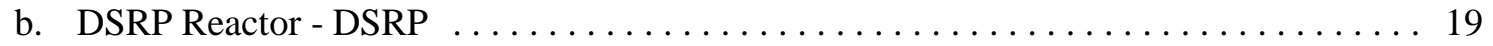

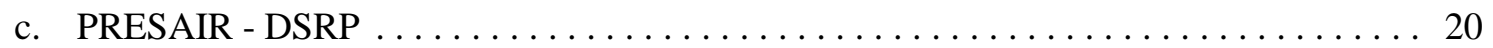

d. RECYCOMP - DSRP . . . . . . . . . . . . . . . . . . . . . . 22

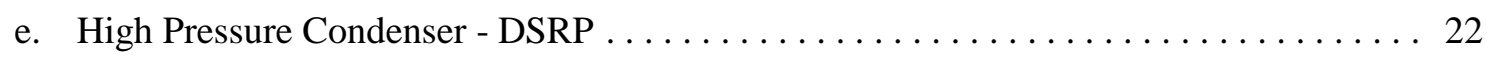

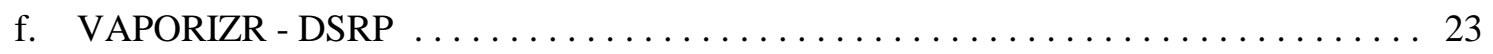

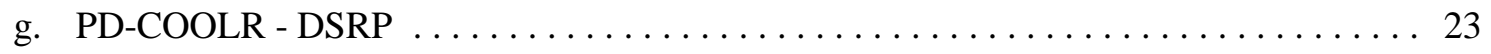

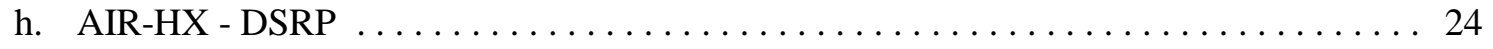

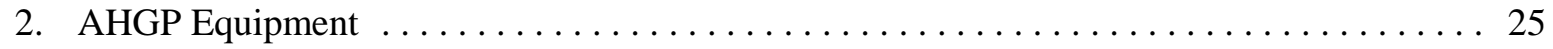

a. Desulfurization and Regeneration Reactors - AHGP . . . . . . . . . . . . . . . 25

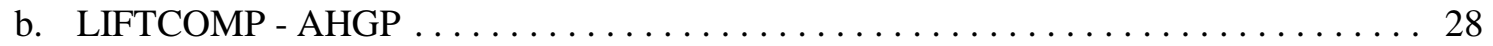

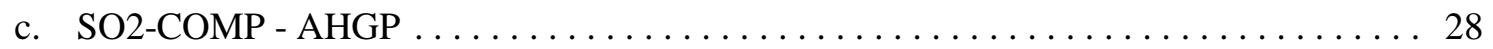

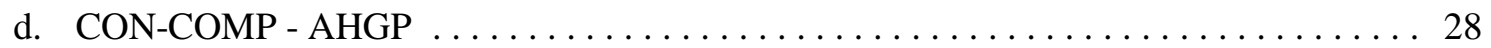




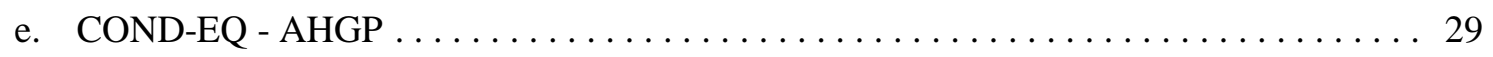

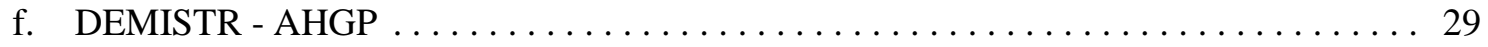

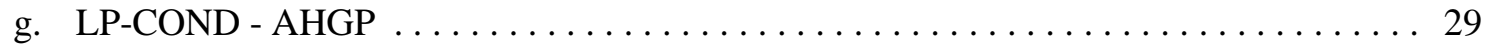

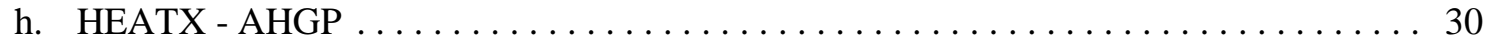

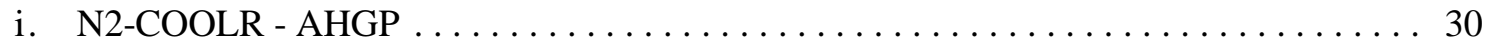

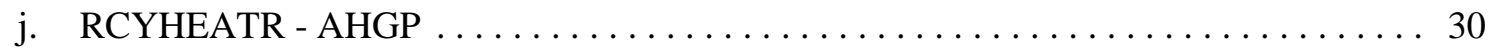

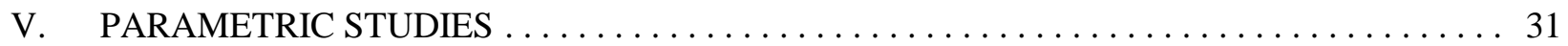

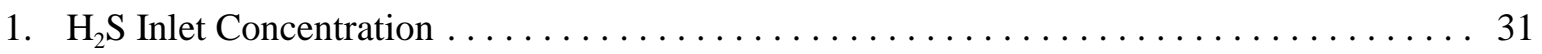

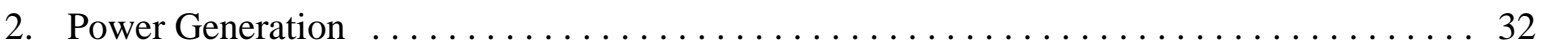

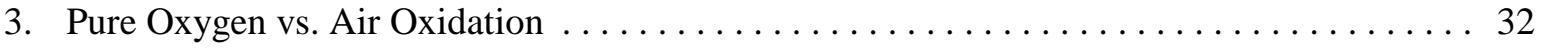

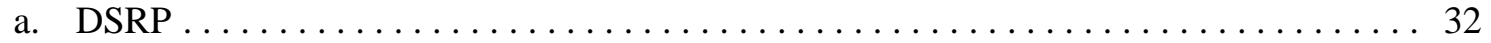

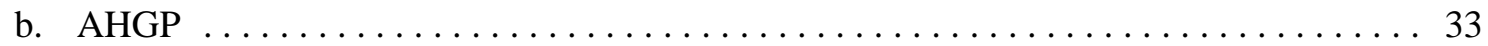

VI. ADDITIONAL PROCESS CONSIDERATIONS $\ldots \ldots \ldots \ldots \ldots \ldots \ldots \ldots \ldots \ldots \ldots$

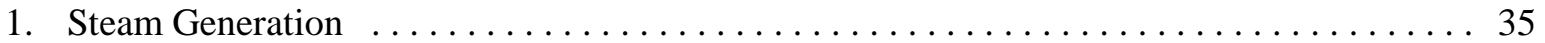

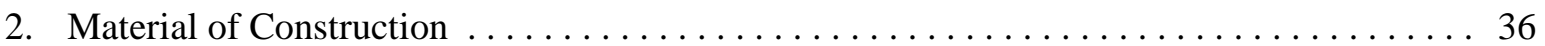

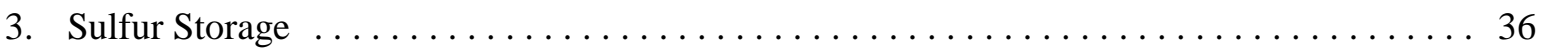

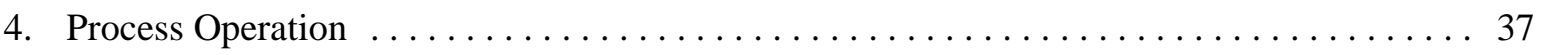

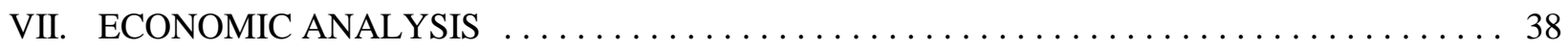

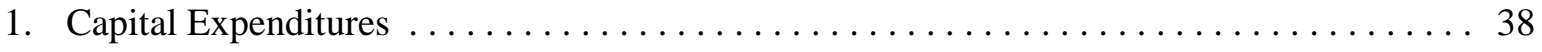

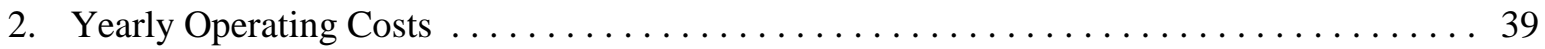

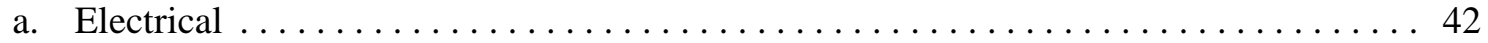

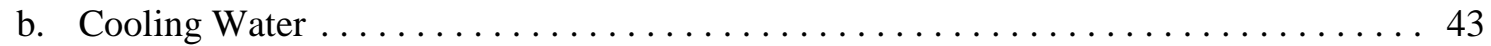

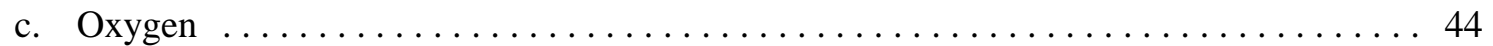

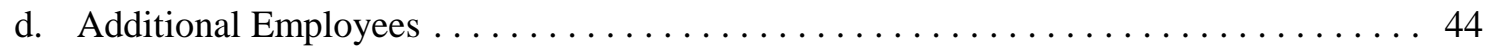

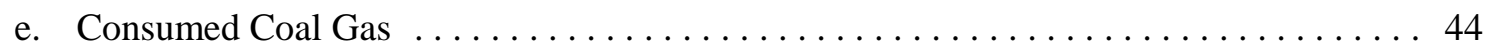

f. Additional Yearly Expenditures $\ldots \ldots \ldots \ldots \ldots \ldots \ldots \ldots \ldots \ldots \ldots \ldots \ldots \ldots$

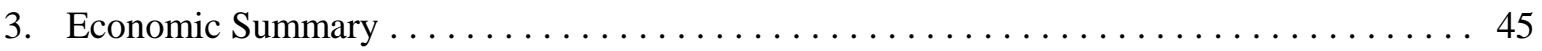

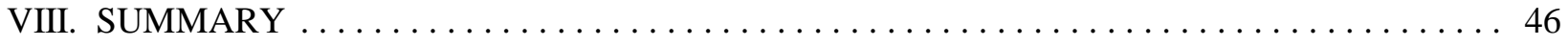

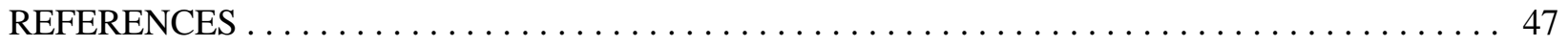

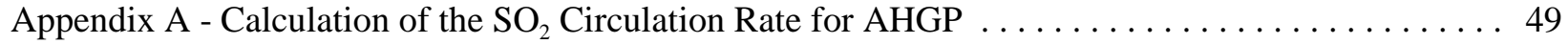

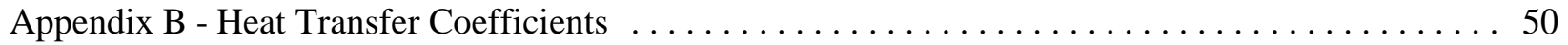

Appendix C - Determination of Catalyst Velocity in DSRP Reactor $\ldots \ldots \ldots \ldots \ldots \ldots \ldots \ldots \ldots$

Appendix D - Calculation of DSRP Catalyst Cycling Rate $\ldots \ldots \ldots \ldots \ldots \ldots \ldots \ldots \ldots \ldots$ 
Appendix E - Process Flowsheets and Stream Summaries $\ldots \ldots \ldots \ldots \ldots \ldots \ldots \ldots \ldots \ldots$

Appendix F - Steam Generation Process Flowsheets $\ldots \ldots \ldots \ldots \ldots \ldots \ldots \ldots \ldots \ldots \ldots$

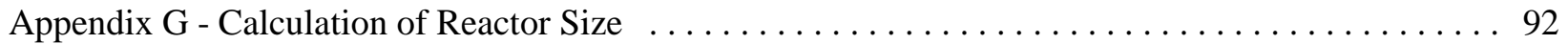

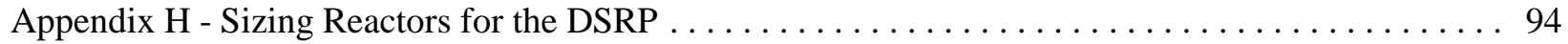

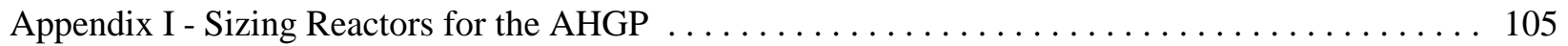

Appendix J - Power Generation Achievable from Clean Coal Gas . . . . . . . . . . . . . . . . . 111

Appendix K - Calculation of Reactor Pressure Drops $\ldots \ldots \ldots \ldots \ldots \ldots \ldots \ldots \ldots \ldots \ldots \ldots$

Appendix L - Summary of the Process Pressure Drops . . . . . . . . . . . . . . . . 117

Appendix M - Summary of Major HGD Equipment $\ldots \ldots \ldots \ldots \ldots \ldots \ldots \ldots \ldots \ldots \ldots \ldots \ldots$

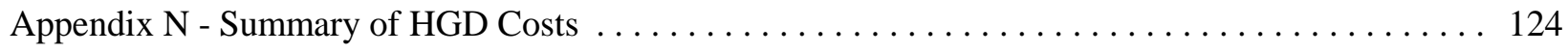

Appendix $\mathrm{O}$ - Reaction Data Obtained from RTI $\ldots \ldots \ldots \ldots \ldots \ldots \ldots \ldots \ldots \ldots \ldots \ldots$ 


\section{LIST OF TABLES}

TABLE \#

PAGE

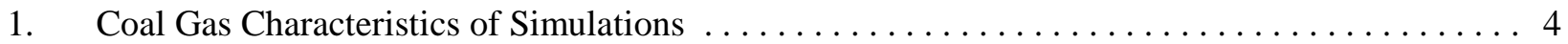

2. Raw Coal Gas Feed to Base Case Simulations $\ldots \ldots \ldots \ldots \ldots \ldots \ldots \ldots \ldots \ldots \ldots$

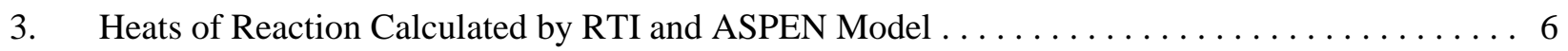

4. Equilibrium Conversion for $\mathrm{FeS}$ Oxidation by $\mathrm{SO}_{2} \ldots \ldots \ldots \ldots \ldots \ldots \ldots$

5. $\mathrm{Al}_{2} \mathrm{O}_{3}$ Circulation Rate Effect on Regenerator Stage 1 Temperature $\ldots \ldots \ldots \ldots \ldots \ldots \ldots 11$

6. Dew Point Temperatures for DSRP Product Distributions $\ldots \ldots \ldots \ldots \ldots \ldots \ldots \ldots \ldots \ldots$

7. Coal Gas Fed to and Consumed by HGD for Various H2S Concentrations $\ldots \ldots \ldots \ldots \ldots 31$

8. $\quad \mathrm{N}_{2}$ Removal at Various N2 Concentrations, Condenser Temperatures and Pressures ...... 34 


\section{$\underline{\text { LIST OF FIGURES }}$}

FIGURE \#

PAGE

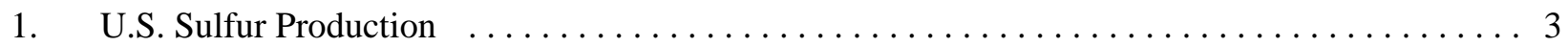

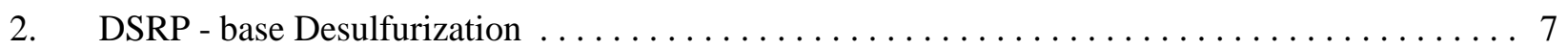

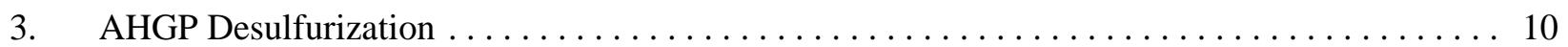

4. RKS and PR Calculated $\mathrm{SO}_{2}$ Vapor Pressure Deviation From Tabulated Values .......... 14

5. Schematic of DSRP - Based HGD Process Desulfurization and Regeneration Reactors . . . . . 18

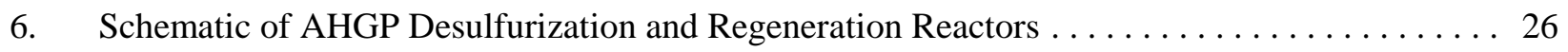

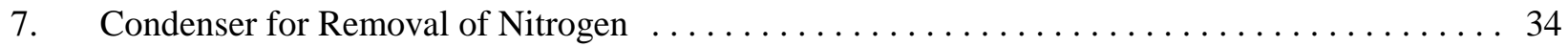

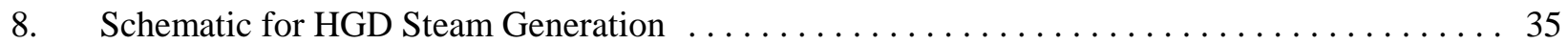

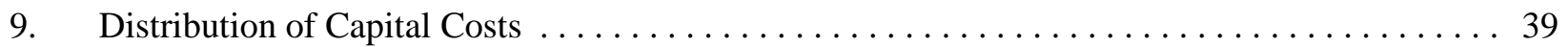

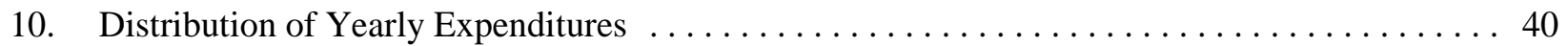

11. Yearly Expenditures for Different Levels of Power Generation $\ldots \ldots \ldots \ldots \ldots \ldots \ldots \ldots \ldots$

12. $\mathrm{H}_{2} \mathrm{~S}$ Concentration's Effect on HGD Yearly Operating Costs $\ldots \ldots \ldots \ldots \ldots \ldots \ldots \ldots \ldots$

13. Power Generation's Effect on HGD Yearly Operating Costs $\ldots \ldots \ldots \ldots \ldots \ldots \ldots \ldots \ldots$

14. Yearly Costs as a Function of Sulfur Feed $\ldots \ldots \ldots \ldots \ldots \ldots \ldots \ldots \ldots \ldots \ldots \ldots \ldots \ldots \ldots \ldots \ldots \ldots$

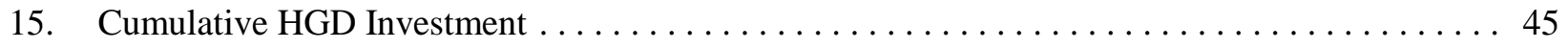




\section{EXECUTIVE SUMMARY}

This report summarizes the process simulation work and economic evaluations that were done under contract to Research Triangle Institute to aid in the design of hot gas desulfurization (HGD) processes. Two processes were evaluated for the removal of sulfur $\left(\right.$ as $\left.\mathrm{H}_{2} \mathrm{~S}\right)$ from coal gas at high temperatures, that produce elemental sulfur as a byproduct. Complete mass and energy balances were accomplished for the Direct Sulfur Recovery Process (DSRP) -based process, for various feed conditions. The Advanced Hot Gas Desulfurization Process (AHGP) was also simulated for various feed conditions. ASPEN PLUS 9.3-1 was used for simulating the processes. The mass and energy balances were used in determining the equipment requirements. Equipment requirements were used for the estimation of capital costs and yearly operating costs.

The technical feasibility of the two processes was briefly evaluated. Operating the DSRP is less complicated than operating the AHGP. The AHGP contains a $\mathrm{SO}_{2}$ loop that is balanced by reactions that consume and generate $\mathrm{SO}_{2}$. The reaction that consumes $\mathrm{SO}_{2}$ is equilibrium limited, and its equilibrium fractional conversion varies substantially over the range of possible reactor temperatures.

The economic evaluation shows that the AHGP has higher capital costs than the DSRP. However, the savings the AHGP provides with lower operating costs makes it the more attractive process. The economics in this report use two key assumptions: that there is a market credit for recovered elemental sulfur, and that the coal gas consumed by the HGD has an operating cost equal to the cost of the electricity that could have been generated from it. Using these and other assumptions, the analysis shows that, after only two years the AHGP should make up for its higher capital cost. After four years, AHGP could save millions over the DSRP (savings depend on plant size and the coal's sulfur concentration). 


\section{INTRODUCTION}

\section{Background}

Integrated gasification combined cycle (IGCC) power plants gasify coal and then combust the coal gas to generate power. All new power plants are required to meet federal $\mathrm{SO}_{\mathrm{X}}$ emission limitations, currently limited to $1.2 \mathrm{lbs}$ per million BTU (Jaffee). Hot-gas desulfurization (HGD) removes sulfur from coal gas before combustion. HGD has the potential of reducing the cost of electricity (COE) in IGCC plants, compared to conventional liquid absorption desulfurization.

IGCC plants gasify coal using steam and either air or oxygen. The coal gas is then combusted and passes through a gas turbine, generating power. The hot exhaust gas from the turbine is then used to generate steam, which is used for additional power generation. Coal gas is produced at high temperatures and high pressures (HTHP), typically 450 to $800^{\circ} \mathrm{C}$ and 145 to 580 psia (Gangwal). HGD reduces the coal gas sulfur content before combustion while maintaining the coal gas at HTHP conditions. Currently, IGCC plants remove sulfur with liquid phase scrubbing. The scrubbing process cools the coal gas stream below $150^{\circ} \mathrm{C}$. The temperature drop reduces thermal efficiency and limits the potential electricity cost reduction that is theoretically possible with IGCC power plants. IGCC power plants using liquid phase scrubbing have COE's equivalent to those of pulverized coal-based power plants (Gangwal). HGD would give IGCC power plants a competitive advantage. Implementing HGD will increase thermal efficiency, reduce the $\mathrm{COE}$, and ensure $\mathrm{SO}_{2}$ emissions are acceptable.

Another benefit of HGD is that the sulfur removed from the coal gas would be recovered as elemental sulfur, a valuable byproduct and easily stored material. This report describes work subcontracted to North Carolina State University (NCSU) from Research Triangle Institute (RTI). Two HGD processes that produce elemental sulfur were simulated using ASPEN PLUS 9.3-1. This work contributes to RTI efforts towards developing HGD technology. RTI research and development work includes sorbents development, characterization and a pilot-scale desulfurization testing. 
Coal gas HGD and sulfur recovery could also be implemented in non-power producing applications. Although not the focus of this report, coal gas is used in methanation and FischerTropsh synthesis. Methanation and Fisher-Tropsh catalysts require $\mathrm{H}_{2} \mathrm{~S}$ concentrations below 1 ppm (Cusumano) because $\mathrm{H}_{2} \mathrm{~S}$ and $\mathrm{SO}_{2}$ poison catalysts with the formation of elemental sulfur.

\section{Sulfur Production}

The main purpose of the two desulfurization processes investigated is to remove sulfur from the coal gas prior to combustion, thereby reducing stack emissions. An advantage of these two processes is that elemental sulfur, which has commercial value, will be generated. Such "recovered sulfur" has been steadily replacing Frasch sulfur as a sulfur source (Figure 1). Frasch sulfur is obtained by drilling into sulfur deposits and injecting hot water, pushing molten sulfur to the surface.

Figure 1: U.S. Sulfur Production

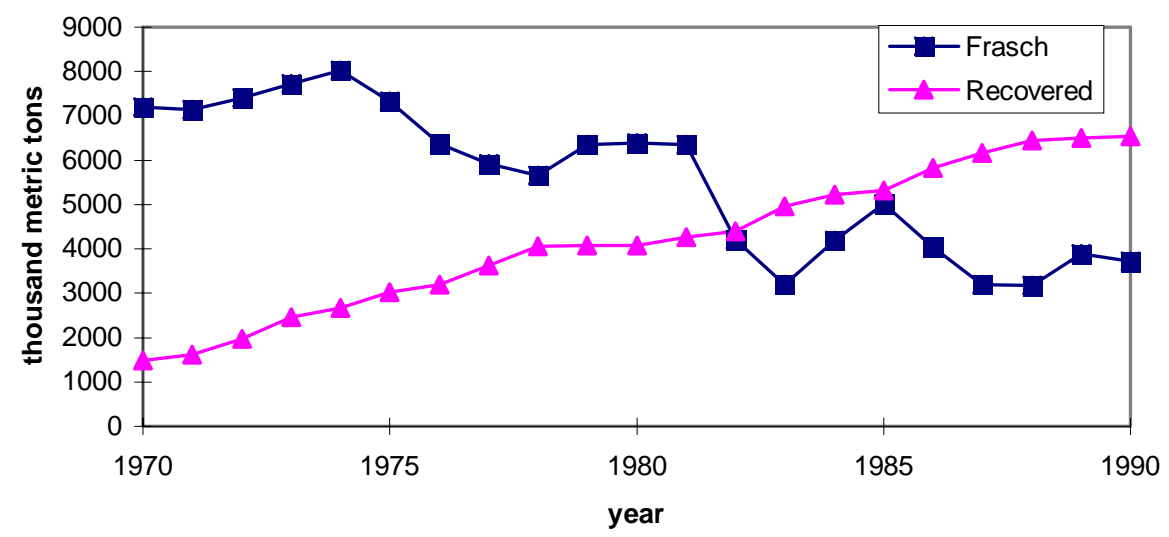

-Data from U.S. Geological Survey

Sulfur is used in both industrial and agricultural applications. In the U.S., the majority of sulfur is used for agricultural purposes (U.S. Geological).

Recovered sulfur can be sold for $\$ 50$ to $\$ 150 /$ ton (Caruanan). Since sulfur purification was not modeled, a $\$ 50 /$ ton credit was assigned to the recovered sulfur for the economic evaluation. 


\section{BASIC PROCESS DESCRIPTIONS}

Two distinct desulfurization processes where simulated, the Direct Sulfur Recovery Process (DSRP) -based process and the Advanced Hot-Gas Process (AHGP). A complete collection of process flowsheets and stream summaries is contained in Appendix E. The defining characteristic of the DSRP -based process is that a slipstream of clean coal gas is used to produce the elemental sulfur from an intermediate regeneration off-gas stream containing sulfur dioxide $\left(\mathrm{SO}_{2}\right)$. The defining characteristic of AHGP is that a $\mathrm{SO}_{2}$ stream (in a recycle loop) is used to regenerate the sorbent and produce elemental sulfur. Base case simulations for both HGD processes, referred to as "DSRP" and "AHGP", have 0.85 mol\% $\mathrm{H}_{2} \mathrm{~S}$ in the coal gas feed. Both base cases also generate $260 \mathrm{MW}$ from the clean coal gas. Simulations that deviate from the base cases use suffixes to denote the changes. Table 1 displays the significance of the suffixes. In all cases the coal gas feed pressure is $275 \mathrm{psia}$ and its temperature is $482^{\circ} \mathrm{C}$. Simulations changes were strongly dependent on the quantity of sulfur removed from the coal gas. There is little distinction between HGD processes deviating the total sulfur removal by changing $\mathrm{H}_{2} \mathrm{~S}$ concentration and those changing sulfur removal by varying the power production.

Table 1: Coal Gas Characteristics of Simulations

$\underline{\text { Simulations }}$

DSRP, AHGP (base cases)

DSRP-b, AHGP-b

DSRP-c, AHGP-c

DSRP-100, AHGP-100

DSRP-500, AHGP-500 $\mathrm{H}_{2} \underline{\mathrm{S} \text { Feed Molar Concentration }}$

$0.85 \%$

$2.50 \%$

$0.25 \%$

$0.85 \%$

$0.85 \%$
MW Produced

260

260

260

110

540

Table 2 shows the composition and flow rate of the "raw" coal gas feed to the base case HGD processes. After sulfur is removed from the streams the coal gas can produce $260 \mathrm{MW}$. 
Table 2 : Raw Coal Gas Feed to Base Case Simulations

$\begin{array}{lcc}\text { Component } & \text { DSRP }(\mathrm{lb} / \mathrm{hr}) & \text { AHGP }(\mathrm{lb} / \mathrm{hr}) \\ \mathrm{H}_{2} \mathrm{~S} & 6,300 & 6,100 \\ \mathrm{H}_{2} \mathrm{O} & 70,500 & 69,000 \\ \mathrm{H}_{2} & 11,800 & 11,500 \\ \mathrm{CO} & 218,200 & 213,400 \\ \mathrm{CO}_{2} & 117,400 & 114,800 \\ \mathrm{~N}_{2} & 36,300 & 35,500 \\ \text { Total } & 460,500 & 450,500\end{array}$

\section{Direct Sulfur Recovery Process Sorbent Cycle}

The term DSRP, strictly speaking, refers only to that part of the entire HGD process that produces elemental sulfur. For convenience, the process simulations were made by assuming a kind of "generic" process (Figure 2) utilizing a $\mathrm{ZnO}$ sorbent, with $\mathrm{Al}_{2} \mathrm{O}_{3}$ support, to remove sulfur (present in the form of $\mathrm{H}_{2} \mathrm{~S}$ ) via reaction 1. The reader should note that in this report "DSRP" is often used as shorthand for the entire "DSRP-based HGD process," while the novel DSRP reactions to form elemental sulfur occur in what this report refers to as the "DSRP Reactor." Reaction 1 occurs in the desulfurization reactor (DESULF, Figure 2).

$$
\mathrm{ZnO}+\mathrm{H}_{2} \mathrm{~S} \rightarrow \mathrm{ZnS}+\mathrm{H}_{2} \mathrm{O}
$$

The spent sorbent is regenerated in an oxidizing environment, forming $\mathrm{SO}_{2}$. Reaction 2 occurs in the regenerator reactor (REGEN, Figure 2), it is driven to completion by oxygen.

$$
\mathrm{ZnS}+3 / 2 \mathrm{O}_{2}->\mathrm{ZnO}+\mathrm{SO}_{2}
$$

The $\mathrm{SO}_{2}$ exits the regenerator in a stream designated regenerator off-gas (ROG). The ROG flows to the DSRP Reactor. A slipstream of clean coal gas is also fed to the DSRP Reactor. The $\mathrm{H}_{2}$ and $\mathrm{CO}$ in the coal gas slipstream participate in catalyzed reactions (3 and 4), converting $\mathrm{SO}_{2}$ 
into elemental sulfur. The reactions 3 and 4 are the simplified overall reactions of a more complex series of reactions.

$$
\begin{aligned}
& \mathrm{H}_{2}+1 / 2 \mathrm{SO}_{2} \rightarrow \mathrm{H}_{2} \mathrm{O}+1 / 4 \mathrm{~S}_{2} \\
& \mathrm{CO}+1 / 2 \mathrm{SO}_{2} \rightarrow \mathrm{CO}_{2}+1 / 4 \mathrm{~S}_{2}
\end{aligned}
$$

The heats of reaction for converting $\mathrm{SO}_{2}$ to elemental sulfur have been calculated by RTI (Portzer, 1996). Comparing RTI calculated values with experimental results indicated the RTI values were reasonable. Table 2 shows that ASPEN calculated heats of reaction are in general agreement with those calculated by RTI. The ASPEN model does an accurate job determining the heat evolved during reactions and therefore will predict correct heat transfer requirements in the process simulations.

Table 3: Heats of Reaction Calculated by RTI and ASPEN Model

\begin{tabular}{rllll} 
Reaction & $\operatorname{Temp}\left({ }^{\circ} \mathrm{C}\right)$ & $\Delta \mathrm{H}_{\text {RTI }}(\mathrm{BTU} / \mathrm{mole})$ & $\Delta \mathrm{H}_{\text {ASPEN }}(\mathrm{BTU} / \mathrm{mole})$ & difference \\
\hline 3 & 550 & $-28,000$ & $-28,700$ & $2.5 \%$ \\
3 & 650 & $-28,300$ & $-29,000$ & $2.5 \%$ \\
3 & 750 & $-28,600$ & $-29,200$ & $2.1 \%$ \\
4 & 550 & $-43,900$ & $-44,100$ & $0.5 \%$ \\
4 & 650 & $-43,700$ & $-44,000$ & $0.7 \%$ \\
4 & 750 & $-43,800$ & $-43,600$ & $0.5 \%$
\end{tabular}

\section{Sorbent Composition - DSRP}

The oxidized sorbent, a mixture of $\mathrm{ZnO}$ and $\mathrm{Al}_{2} \mathrm{O}_{3}$, was assumed to contain $15 \mathrm{wt} \%$ zinc metal. This distribution is based on an assumed, "generic" sorbent defined by RTI, and results in an oxidized sorbent containing $18.671 \mathrm{wt} \% \mathrm{ZnO}$ with the balance as inert $\mathrm{Al}_{2} \mathrm{O}_{3}$ support. While developing the process model and adjusting the stream flow rates to achieve the desired heat balance, it became desirable to increase sorbent circulation rates above the stoichiometric requirements. For these models, the ratio of $\mathrm{Zn}$ to $\mathrm{Al}$ remained unchanged. The excess $\mathrm{Zn}$ sorbent circulating through the system was assumed to remain in the sulfide state $(\mathrm{ZnS})$. 


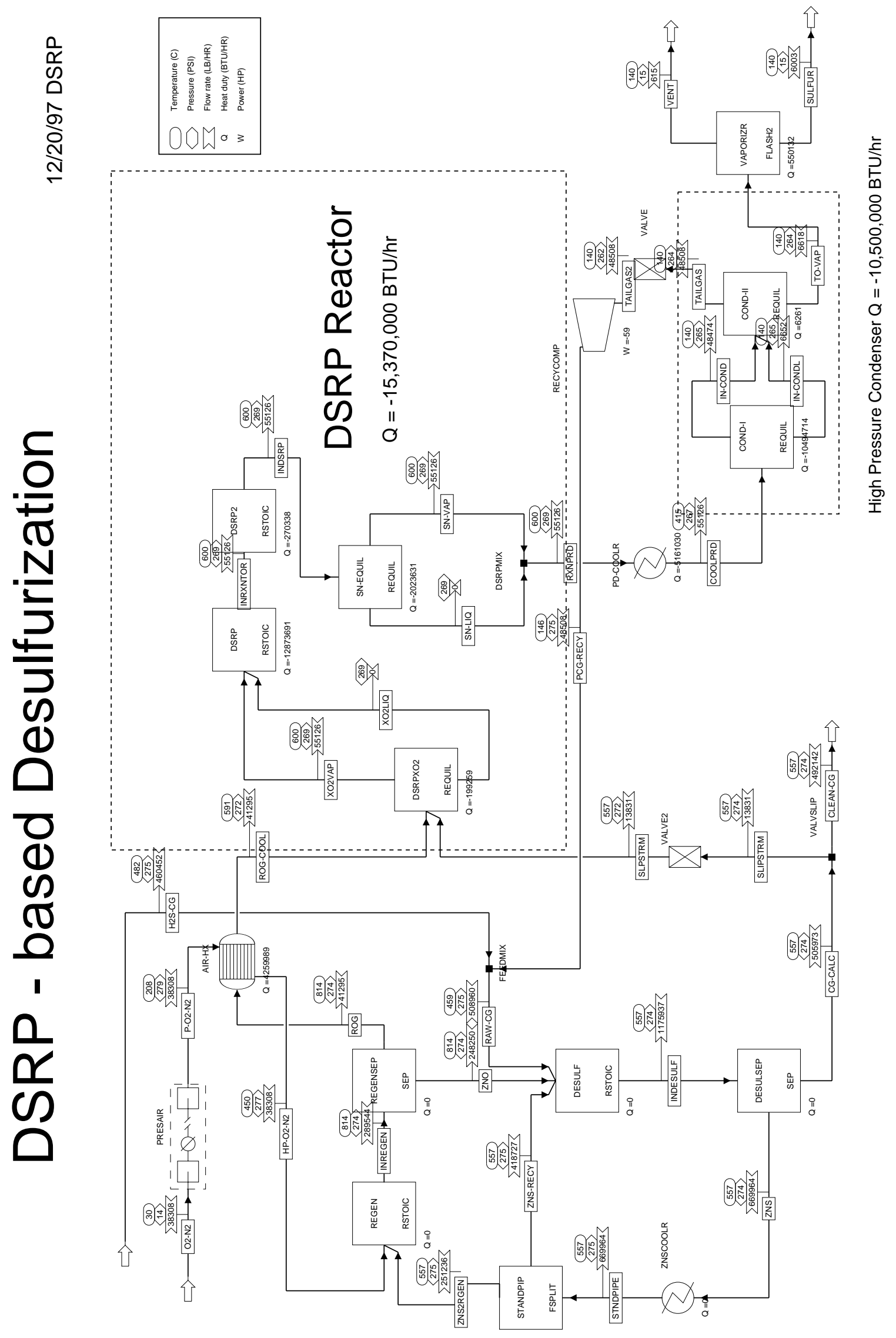




\section{Advanced Hot Gas Process Sorbent Cycle}

The AHGP (Figure 3) uses a sorbent containing a mixture of $\mathrm{ZnO}$ and $\mathrm{Fe}_{2} \mathrm{O}_{3}$ on $\mathrm{Al}_{2} \mathrm{O}_{3}$ support for removing $\mathrm{H}_{2} \mathrm{~S}$ from the coal gas and converting it into elemental sulfur. Both zinc and iron components react with the $\mathrm{H}_{2} \mathrm{~S}$ present in the coal gas. The desulfurization reactions are represented below.

$$
\begin{aligned}
& \mathrm{ZnO}+\mathrm{H}_{2} \mathrm{~S}>\mathrm{H}_{2} \mathrm{O}+\mathrm{ZnS} \\
& \mathrm{Fe}_{2} \mathrm{O}_{3}+2 \mathrm{H}_{2} \mathrm{~S}+\mathrm{H}_{2}>2 \mathrm{FeS}+3 \mathrm{H}_{2} \mathrm{O}
\end{aligned}
$$

The sulfided sorbent is sent to a three-stage regenerating reactor that reoxidizes the sorbent and generates elemental sulfur. Sorbent and a $\mathrm{SO}_{2}$ gas stream flow counter-currently through the regenerator (Figure 3) (Figure 6). The sorbent enters the regenerator at the HXSTAGE (the third and highest elevated stage) where the sorbent is heated by the effluent gas stream. Sorbent descends to REGEN2 (the second stage) where $\mathrm{SO}_{2}$, present in great excess, oxidizes the majority of the FeS sorbent.

$$
3 \mathrm{SO}_{2}+4 \mathrm{FeS} \Leftrightarrow 7 / 2 \mathrm{~S}_{2}+2 \mathrm{Fe}_{2} \mathrm{O}_{3}
$$

It has been assumed that two-thirds of the FeS oxidizes in REGEN2. Calculated equilibrium conversions for reaction 7 are listed in table 4 . Sorbent enters the second stage of the regenerator at $512^{\circ} \mathrm{C}$ and gas enters the second stage at $715^{\circ} \mathrm{C}$. Table 3 shows equilibrium conversions varies significantly over the range of temperatures possible in stage 2 , a stage for which it is unclear what value represents its temperature the best. Simulated stage 2 exit temperatures were $580^{\circ} \mathrm{C}$, this exit temperature assumes perfectly mixed behavior in the stage 2 . In reality there will likely be higher temperatures at lower elevations in the stage. The ASPEN model uses an RSTOICH block to simulate this stage so that the conversion can be arbitrarily fixed at $67 \%$. This value was defined by RTI, based on experimental data. The information in Table 4 suggests that the assumed two-thirds conversion probably overestimates the actual conversion. In commercial practice, increasing the Fe: $\mathrm{Zn}$ ratio could compensate for lower than simulated reaction 7 conversions (conversion written in terms of FeS). Another aspect of this reactor stage is that the 
extent that $\mathrm{FeS}$ oxidizes by $\mathrm{SO}_{2}$ will vary with temperature fluctuations and increase the difficulty in balancing $\mathrm{SO}_{2}$ consumption and generation.

Table 4: Equilibrium Conversion for FeS Oxidation by $\mathrm{SO}_{2}$ $\underline{\text { Regenerator Temperature }\left({ }^{\circ} \mathrm{C}\right) \quad \text { Equilibrium Fractional Conversion }}$

$\begin{array}{ll}500 & 0.43 \\ 550 & 0.53 \\ 600 & 0.65 \\ 650 & 0.77 \\ 700 & 0.90\end{array}$

Equilibrium calculated from ASPEN REQUIL block, $\mathrm{P}=275$ psia

Sorbent oxidization approaches completion in the bottom regenerator stage (REGEN1, Figure 3). REGEN1 oxidizes the sorbent using pure oxygen (reactions 8 and 9). The oxidation generates $\mathrm{SO}_{2}$, making up for $\mathrm{SO}_{2}$ used in reaction 7 .

$$
\begin{aligned}
& 7 / 2 \mathrm{O}_{2}+2 \mathrm{FeS} \rightarrow 2 \mathrm{SO}_{2}+\mathrm{Fe}_{2} \mathrm{O}_{3} \\
& 3 / 2 \mathrm{O}_{2}+\mathrm{ZnS} \rightarrow \mathrm{SO}_{2}+\mathrm{ZnO}
\end{aligned}
$$

This modeling assumes that $\mathrm{SO}_{2}$ does not oxidize sorbent in REGEN1, since equilibrium conversion for $\mathrm{SO}_{2}$ oxidation is approached in REGEN2. The equilibrium regeneration of sorbent by $\mathrm{SO}_{2}$ will be quickly superseded by oxygen regeneration.

\section{Sorbent Composition - AHGP}

AHGP sorbent composition was defined by RTI to contain $3 \mathrm{wt} \% \mathrm{Zn}$ and $12 \mathrm{wt} \% \mathrm{Fe}$, which corresponds to $3.734 \mathrm{wt} \% \mathrm{ZnO}$ and $17.154 \mathrm{wt} \% \mathrm{Fe}_{2} \mathrm{O}_{3}$. The balance, $79.109 \mathrm{wt} \%$, was inert $\mathrm{Al}_{2} \mathrm{O}_{3}$. As discussed above, the ratio of $\mathrm{Fe}$ to $\mathrm{Zn}$ will need to be increased if the actual conversion for reaction 7 is lower than 0.667 , its assumed value. 


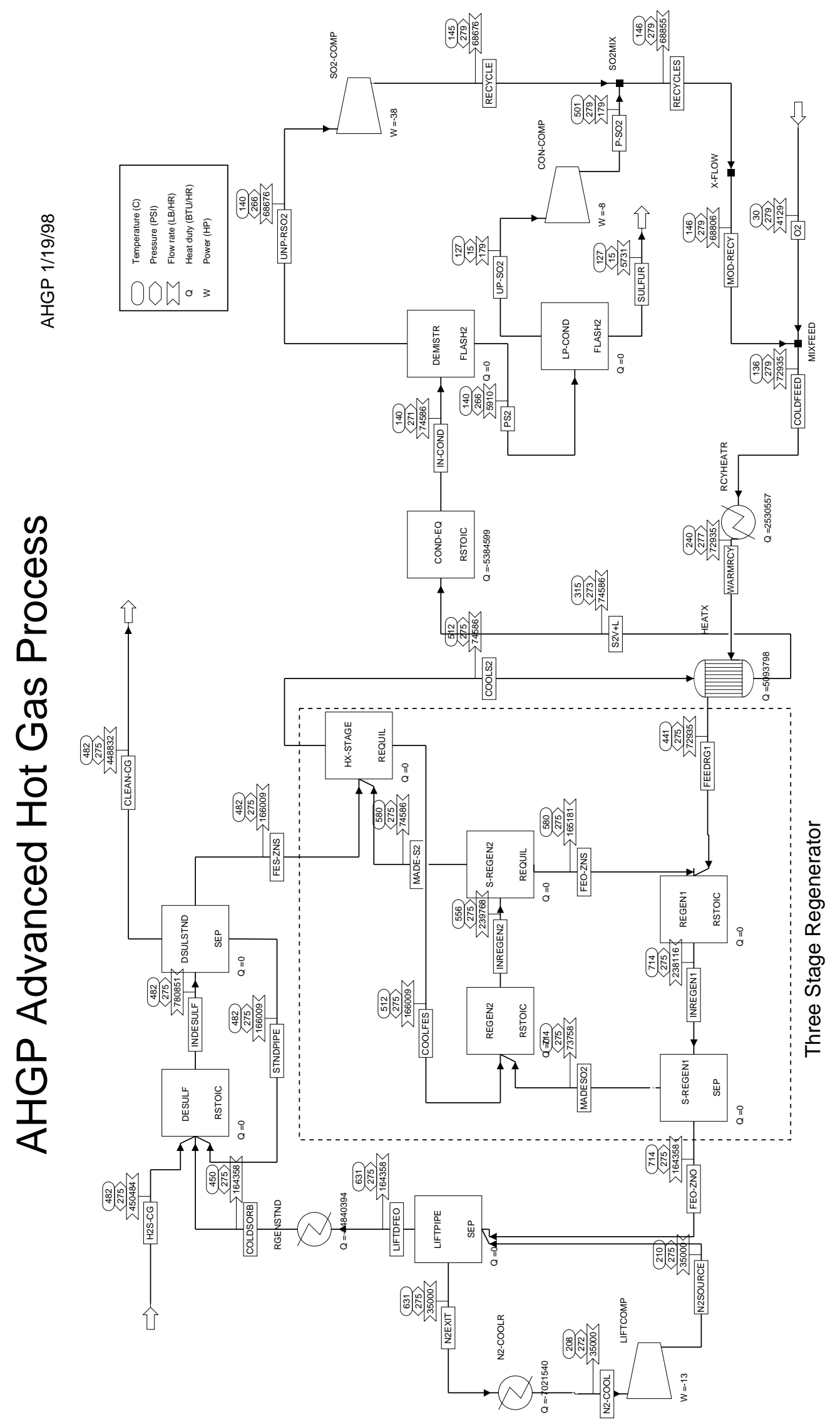


During subsequent simulation development and adjustment of stream flow rates to achieve the desired heat balance, it became apparent the defined sorbent composition was not optimal. To run the reactors adiabatically, it was necessary to increase sorbent flow. Circulating more sorbent increased the heat capacity of the reactive stream and reduced the adiabatic temperature rise. Such a sorbent increase required an increase in $\mathrm{Al}_{2} \mathrm{O}_{3}$ flow. Increasing $\mathrm{Fe}$ or $\mathrm{Zn}$ flow would have upset the $\mathrm{SO}_{2}$ generation and consumption balance created by reactions 7,8 and 9. Therefore, alumina flow was increased. The effect would be the same as adding pure alumina sorbent to the reactor system, or by manufacturing a sorbent that has a lower active metal content and increasing the total flow to match the amount of alumina added.

The $\mathrm{Al}_{2} \mathrm{O}_{3}$ circulation was increased until an adiabatic regenerating reactor would operate below $716^{\circ} \mathrm{C}$. The effects of changing $\mathrm{Al}_{2} \mathrm{O}_{3}$ circulation ripple through the process. The required $\mathrm{SO}_{2}$ circulation rate was affected by varying the $\mathrm{Al}_{2} \mathrm{O}_{3}$ flow. The desired $\mathrm{SO}_{2}$ volumetric flow rate increased with increasing sorbent flow rate because of increased reactor size. Increasing the $\mathrm{SO}_{2}$ circulation helped reduce the adiabatic temperature rise, lessening the need to increase sorbent flow. Table 5 shows how $\mathrm{Al}_{2} \mathrm{O}_{3}$ flow was increased until an acceptable adiabatic regeneration temperature was achieved. The table displays the stepwise approach used to determine the $\mathrm{Al}_{2} \mathrm{O}_{3}$ circulation needed in the AHGP-b simulation (-b signifies a $2.5 \mathrm{~mol} \%$ $\mathrm{H}_{2} \mathrm{~S}$ in the feed). In the simulation, $\mathrm{ZnS}$ and $\mathrm{FeS}$ flow rates (leaving the desulfurization reactor) were constant at 7,600 lb/hr and 41,000 lb/hr, respectively.

Table 5: $\mathrm{Al}_{2} \mathrm{O}_{3}$ Circulation Rate Effect on Regenerator Stage 1 Temperature

$\begin{array}{lll}\underline{\mathrm{Al}}_{2} \underline{\mathrm{O}}_{3}(\mathrm{lb} / \mathrm{hr}) & \mathrm{T}_{\text {REGEN } 1}\left({ }^{\circ} \mathrm{C}\right) & \text { Desired } \mathrm{SO}_{2} \text { flow }\left(\mathrm{ft}^{3} / \mathrm{hr}\right) \\ 165,297 & 1025 & 102,000 \\ 330,594 & 787 & 181,000 \\ 400,000 & 759 & 214,000 \\ 450,000 & 715 & 238,000\end{array}$




\section{PHYSICAL PROPERTIES}

\section{Equation of State}

All simulations discussed in this report used the Peng Robinson cubic equation of state with the Boston-Mathias alpha function (PR-BM).

\section{1.a. Equation of State's Importance}

Modeling unit operations requires physical property information for all compounds present. In calculating thermodynamic equilibrium, fugacity coefficients are used to determine phase equilibrium. An equation of state can be used for the calculation of fugacity, as well as other important physical properties. The equation of state also relates pressure, temperature, and molar volume so that only two need to be specified and the third can be calculated. Phase equilibrium is established when the fugacity of each component is the same in all phases. A two-phase (vapor and liquid) system is at equilibrium when:

$$
\mathrm{f}_{\mathrm{i}}^{\mathrm{v}}=\mathrm{f}_{\mathrm{i}}^{1} \quad \mathrm{i}=1,2, \ldots \mathrm{N} \text { where } \mathrm{N} \text { is the number of compounds }
$$

Where:

$$
\begin{array}{ll}
\mathrm{f}_{\mathrm{i}}^{\mathrm{v}}=\varphi_{{ }_{\mathrm{i}} \mathrm{y}_{\mathrm{i}} \mathrm{P}}^{\mathrm{v}} & \text { Fugacity of component } i \text { in the vapor phase } \\
\mathrm{f}_{\mathrm{i}}^{\mathrm{l}}=\varphi_{\mathrm{i} \mathrm{x}_{\mathrm{i}} \mathrm{P}}^{\mathrm{l}} & \text { Fugacity of component } i \text { in the liquid phase } \\
& \ln \varphi_{\mathrm{i}}^{\alpha}=-\frac{1}{\mathrm{RT}} \int_{\infty}^{\mathrm{V}^{\alpha}}\left[\left(\frac{\partial \mathrm{P}}{\partial \mathrm{n}_{\mathrm{i}}}\right)_{\mathrm{T}, \mathrm{V}, \mathrm{n}_{\mathrm{i} \neq \mathrm{j}}}-\frac{\mathrm{RT}}{\mathrm{V}}\right] \mathrm{dV}-\ln \mathrm{Z}_{\mathrm{m}}^{\alpha}
\end{array}
$$

Notation:

$\begin{array}{llllll}\alpha & = & \text { vapor or liquid }(\mathrm{v} \text { or } \mathrm{l}) & \mathrm{P} & = & \text { Pressure } \\ \mathrm{n}_{\mathrm{i}} & = & \text { Mole number of component } i & \mathrm{~T} & = & \text { Temperature } \\ \mathrm{x}_{\mathrm{i}} & = & \text { Liquid mole faction of component } i & \mathrm{R} & = & \text { Gas Constant } \\ \mathrm{y}_{\mathrm{i}} & = & \text { Vapor mole faction of component } i & \mathrm{~V} & = & \text { Total volume } \\ \mathrm{Z} & = & \text { Compressibility factor } & & \end{array}$


The equation of state also is used to determine other properties via departure functions.

- Enthalpy departure:

$$
\left(\mathrm{H}_{\mathrm{m}}-\mathrm{H}_{\mathrm{m}}^{\mathrm{ig}}\right)=-\int_{\infty}^{\mathrm{V}}\left(\mathrm{P}-\frac{\mathrm{RT}}{\mathrm{V}}\right) \mathrm{dV}-\mathrm{RT} \ln \left(\frac{\mathrm{V}}{\mathrm{V}^{\mathrm{ig}}}\right)+\mathrm{T}\left(\mathrm{S}_{\mathrm{m}}-\mathrm{S}_{\mathrm{m}}^{\mathrm{ig}}\right)+\mathrm{RT}\left(\mathrm{Z}_{\mathrm{m}}-1\right)
$$

- Entropy departure:

$$
\left(S_{\mathrm{m}}-\mathrm{S}_{\mathrm{m}}^{\mathrm{ig}}\right)=-\int_{\infty}^{\mathrm{V}}\left[\left(\frac{\partial \mathrm{P}}{\partial \mathrm{T}}\right)_{\mathrm{V}}-\frac{\mathrm{R}}{\mathrm{V}}\right] \mathrm{dV}+\mathrm{R} \ln \left(\frac{\mathrm{V}}{\mathrm{V}^{\mathrm{ig}}}\right)
$$

- Gibbs Free Energy departure:

$$
\left(G_{m}-G_{m}^{i g}\right)=-\int_{\infty}^{\mathrm{V}}\left(P-\frac{R T}{V}\right) d V-R T \ln \left(\frac{V}{V^{i g}}\right)+R T\left(Z_{m}-1\right)
$$

Notation:

$$
\mathrm{H}=\text { Enthalpy } \quad \mathrm{S}=\text { Entropy } \quad \mathrm{G}=\text { Gibbs Free Energy }
$$

ig (superscript) denotes variable's value for ideal gas

$\mathrm{m}$ (subscript) denotes variable's value for the mixture

\section{1.b. Selection}

The Peng Robinson cubic equation of state with the Boston-Mathias alpha function (PR$\mathrm{BM}$ ) was used in these simulations because it was recommended for gas-processing, refinery, and petrochemical applications (ASPEN PLUS- Reference Manual 2). It was recommend for modeling nonpolar and mildly polar mixtures, including hydrocarbons and light gases like: carbon dioxide, hydrogen sulfide, and hydrogen. Reasonable results can be expected for all temperatures and pressures. The Peng-Robinson equation of state is:

$$
\mathrm{P}=\frac{\mathrm{RT}}{\mathrm{V}_{\mathrm{m}}-\mathrm{b}}-\frac{\mathrm{a}}{\mathrm{V}_{\mathrm{m}}\left(\mathrm{V}_{\mathrm{m}}+\mathrm{b}\right)+\mathrm{b}\left(\mathrm{V}_{\mathrm{m}}-\mathrm{b}\right)}
$$


Variables ' $\mathrm{a}$ ' and ' $\mathrm{b}$ ' account for attractive forces and the space occupied by all species present, $\mathrm{R}$ is the ideal gas constant, $\mathrm{T}$ is temperature and $\mathrm{V}_{\mathrm{m}}$ is the mixture's specific molar volume.

The Boston Mathias extrapolation is used for supercritical components. Boston and Mathias derived an alpha function that is particularly good at modeling decreasing attraction between molecules at high temperatures (ASPEN PLUS- Reference Manual 2).

The above descriptions also apply to the Redlich-Kwong-Soave cubic equation of state with Boston-Mathias alpha function (RKS-BM). The decision to use the PR-BM over RKS-BM was made after comparing literature phase data (Braker) with simulations using both property option sets. Figure 4 shows the fractional deviation of simulated vapor pressures compared to literature values. Both equations of state calculate values in good agreement with actual values, and the Peng-Robinson equation of state gives the best results.

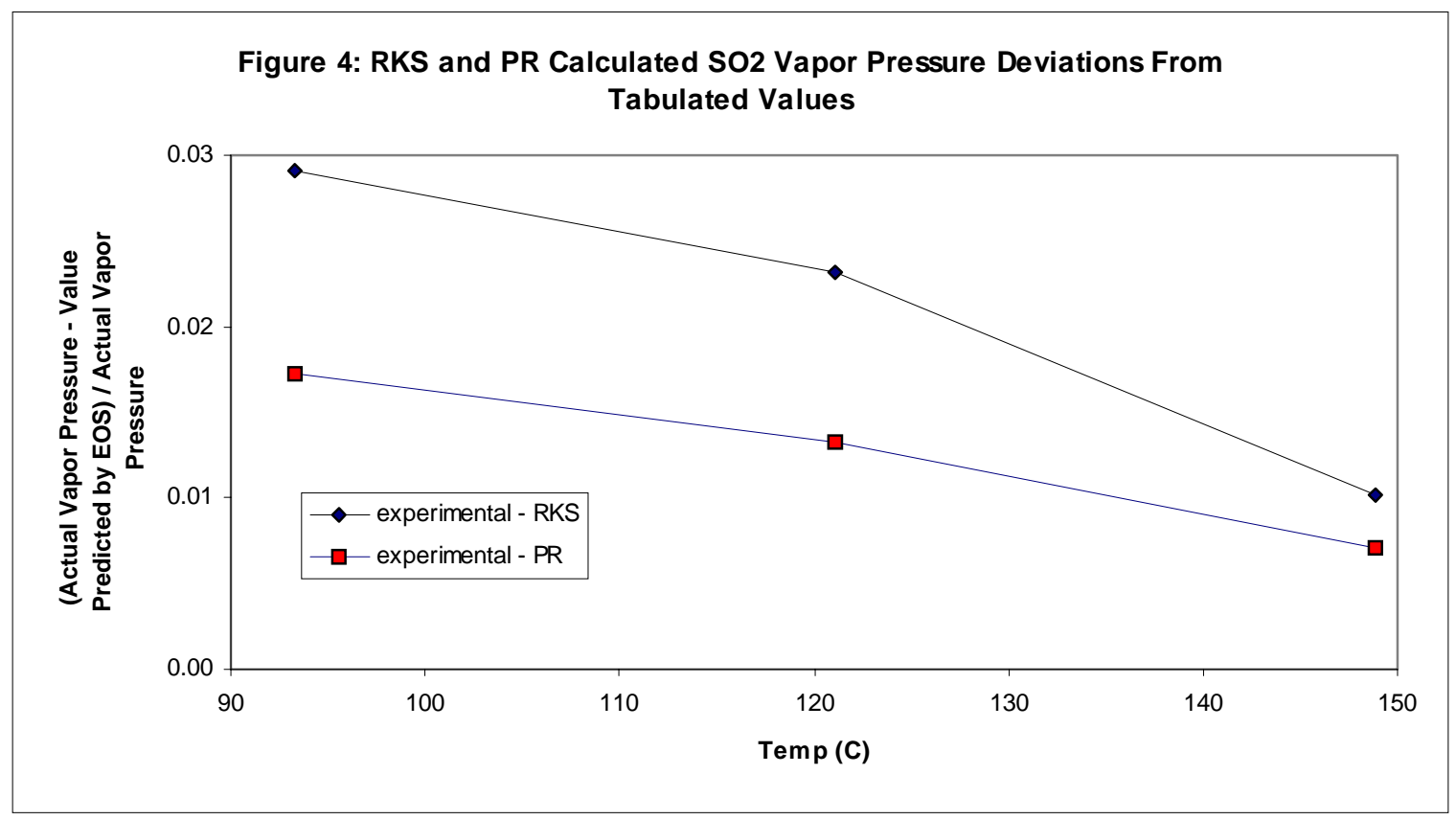




\section{Elemental Sulfur}

Accurately predicting elemental sulfur properties requires knowing which allotropes of sulfur will be formed. For the conditions occurring in the HGD process $S_{8}, S_{6}$, and $S_{2}$ are the predominant allotropes (Barnett; Cotton). Temperature is the dominant variable affecting the equilibrium sulfur distribution. The ASPEN simulations concurred with literature distributions, predicting $S_{2}$ predominance at high temperatures (reactor temperatures), and a shift towards $S_{8}$ and $S_{6}$ at lower temperatures (condenser temperatures). Accurate sulfur distributions are important for the integrity of phase equilibrium predictions. In addition, correctly simulating sulfur equilibrium increases the accuracy of energy balances.

It is worth noting some unusual properties of liquid elemental sulfur. Recovered sulfur should not be raised to temperatures above $159^{\circ} \mathrm{C}$, as above that temperature the liquid sulfur becomes increasingly viscous (Cotton). Sulfur melts around $114^{\circ} \mathrm{C}$; it does not have a sharp melting point due to the presence of various allotropes (Barnett). 


\section{EQUIPMENT}

\section{DSRP- Based Process Equipment}

For the purposes of this process simulation and economic evaluation, the DSRP - based HGD process was defined to have a desulfurization and regeneration transport reactor network as shown in Figure 5. Sulfur is removed from coal gas (Reaction 1) in the desulfurization reactor and sorbent regeneration (Reaction 2) takes place in the regeneration reactor. There is also a DSRP Reactor in which the elemental sulfur is formed via Reactions 3 and 4. Other major pieces of equipment in the DSRP include compressors, condensers, and heat exchangers.

$$
\begin{aligned}
& \mathrm{ZnO}+\mathrm{H}_{2} \mathrm{~S}->\mathrm{ZnS}+\mathrm{H}_{2} \mathrm{O} \\
& \mathrm{ZnS}+3 / 2 \mathrm{O}_{2} \rightarrow \mathrm{ZnO}+\mathrm{SO}_{2} \\
& \mathrm{H}_{2}+1 / 2 \mathrm{SO}_{2} \rightarrow \mathrm{H}_{2} \mathrm{O}+1 / 4 \mathrm{~S}_{2} \\
& \mathrm{CO}+1 / 2 \mathrm{SO}_{2} \rightarrow \mathrm{CO}_{2}+1 / 4 \mathrm{~S}_{2}
\end{aligned}
$$

In addition to Reactions 3 and 4, intermediate and side reactions occur in the DSRP Reactor. They are discussed later in the report.

\section{1.a. Desulfurization and Regeneration Transport Reactors - DSRP}

The DSRP - based HGD process is assumed to use transport reactors for the desulfurization and regeneration reactions. The Sierra Pacific hot-gas desulfurization system (Cambell) has been the basis for the reactor system design (Figure 5). Cyclones separate the sorbent from the exiting gas streams. Sorbent settles from the cyclones into standpipes. The sorbent has a relatively high residence time in the standpipes. Standpipe residence times are several minutes while reactor residence times are only several seconds long. Standpipe heat exchangers remove heat from the reactor system. During startup, sending steam through the standpipe heat exchanger could heat the sorbent partially up to reactor temperatures. 
The regeneration reaction releases a substantial amount of heat. Feeding a stoichiometric amount of sorbent in the ASPEN simulation to an adiabatic regeneration reactor results in predicted temperatures surpassing $1,000^{\circ} \mathrm{C}$ (DSRP base case). RTI guidelines stated that HGD sorbents would experience substantial sintering at temperatures above $815^{\circ} \mathrm{C}$. The strategy adopted to control reactor temperature is recycling excess sorbent. The additional sorbent increases the total heat capacity of the reactive streams. The additional sorbent will not result in additional reactions and the increased heat capacity will decrease the adiabatic temperature rise. The adiabatic temperature rise can be expressed by the following relationship:

$$
\Delta \mathrm{T}_{\text {adiabatic }} \approx \frac{\Delta \mathrm{H}_{\mathrm{rxn}}}{\mathrm{Cp}_{\text {stream }}}
$$

Increased sorbent flow was selected as the preferred strategy over that of using a reactor heat exchanger, since it simplifies reactor design. Furthermore, hot spots are more likely to occur in a reactor containing a heat exchanger. Limiting reactor temperature by reducing reactor feed stream temperatures (without additional sorbent circulation) was also investigated. This approach was discarded because the reactions would be extinguished at feed temperatures low enough to keep the reactor temperature below $815^{\circ} \mathrm{C}$. 
Figure 5: Schematic of DSRP - Based HGD Process Desulfurization and Regeneration Reactors

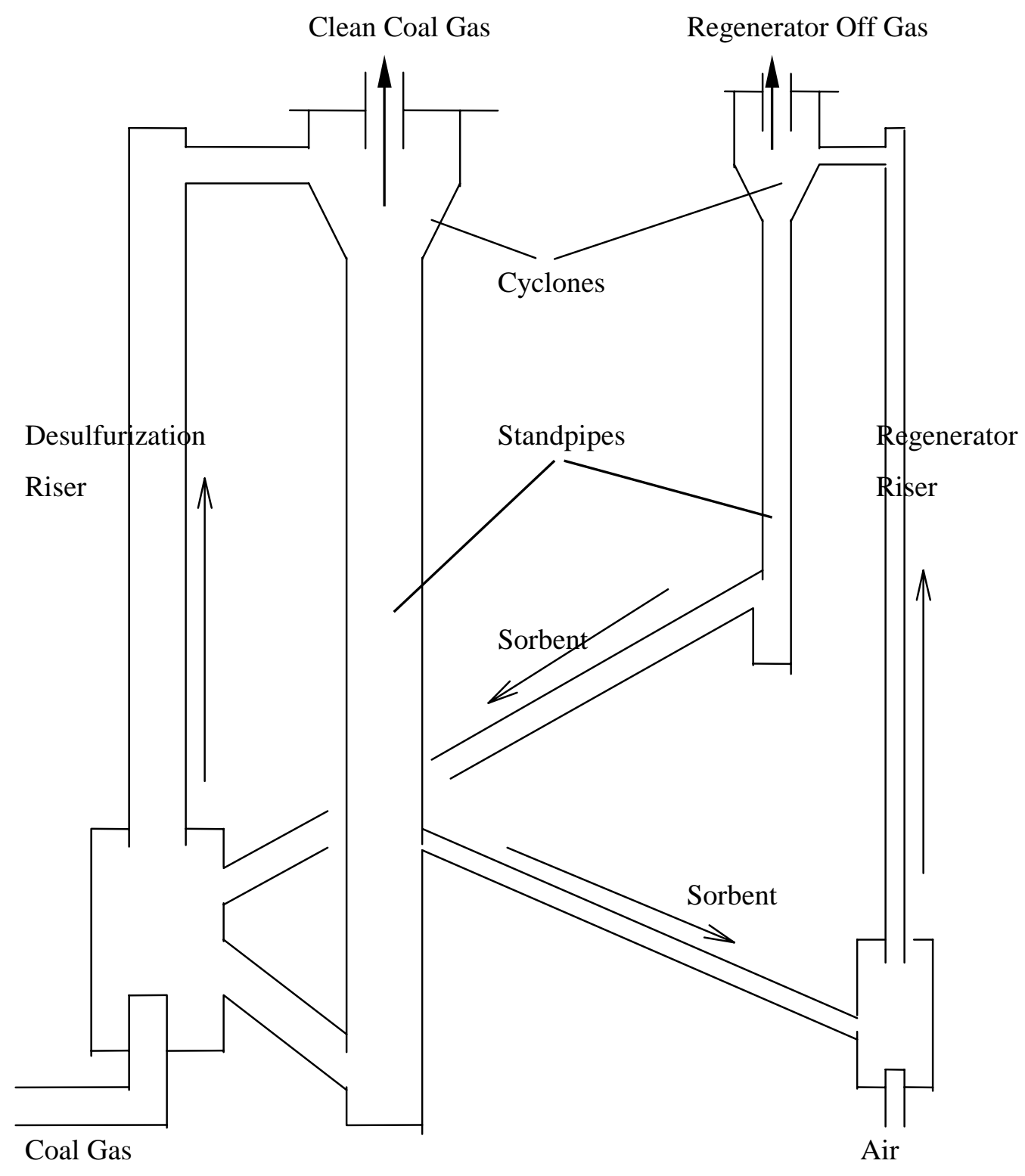


The transport reactors exhibit numerous advantages over fixed-bed, fluid-bed and moving-bed reactors. The transport reactor has lower capital cost, its high flowrate of sorbent controls reactor temperatures, and the high velocities prevent hot spots from occurring on the sorbent (Campbell). The transport reactor's superior temperature control allows undiluted air to be used during regeneration.

The equations used for sizing and costing the DSRP - based process desulfurization and regeneration transport reactor system are described in Appendix G-Calculation of Reactor Size. The actual calculations can be found in Appendix H-Sizing Reactors for the DSRP.

\section{1.b. DSRP Reactor - DSRP}

The DSRP Reactor itself is a fast fluidized bed reactor with its catalyst modeled as $\mathrm{Al}_{2} \mathrm{O}_{3}$. There are several ASPEN blocks used to model what will be only one DSRP Reactor, a dashed box has been drawn around the series of blocks used (Figure 2). The catalyst is circulated through the reactor and an external heat exchanger. Heat is removed by cooling the catalyst while it is outside the reactor. The heat exchanger cools the catalyst to $500^{\circ} \mathrm{C}$ and the catalyst is then reintroduced to the reactor at a rate that is high enough to keep the DSRP Reactor effluent near $600^{\circ} \mathrm{C}$. (Appendix D- Calculation of DSRP Catalyst Cycling Rate)

Figure 2 shows that several blocks were used for the simulation of the DSRP Reactor: DSRPXO2, DSRP, DSRP2, and SN-EQUIL.

In DSRPXO2, any oxygen that enters the DSRP as a contaminant in the ROG consumes coal gas by a conventional combustion reaction. The oxygen combines with $\mathrm{CO}$ forming $\mathrm{CO}_{2}$. It is not necessary to model combustion of $\mathrm{H}_{2}$ since the ratio of $\mathrm{CO}$ to $\mathrm{H}_{2}$ will be set by the Water Gas Shift (WGS) reaction. Also in DSRPXO2 the WGS reaches equilibrium. The WGS reaction is known to reach equilibrium before the reactions of $\mathrm{SO}_{2}$ with $\mathrm{H}_{2}$ or $\mathrm{CO}$ begin (Chen, 
1994). DSRPXO2 uses a Gibbs Free Energy calculation to establish equilibrium for reactions 10 and 11 .

$$
\begin{array}{lll}
\text { DSRPXO2 } & \mathrm{CO}+1 / 2 \mathrm{O}_{2} \rightarrow \mathrm{CO}_{2} & \mathrm{X}_{\mathrm{O} 2}=1 \\
& \mathrm{H}_{2} \mathrm{O}+\mathrm{CO}=\mathrm{CO}_{2}+\mathrm{H}_{2} & \mathrm{~K}_{\mathrm{C}}\left(600^{\circ} \mathrm{C}\right)=2.6
\end{array}
$$

The key DSRP reactions have been modeled in the following blocks.

$$
\begin{array}{lll}
\text { DSRP } & 2 \mathrm{H}_{2}+\mathrm{SO}_{2} \rightarrow 0.5 \mathrm{~S}_{2}+2 \mathrm{H}_{2} \mathrm{O} & \mathrm{X}_{\mathrm{H} 2}=0.99 \\
& 3 \mathrm{CO}+\mathrm{SO}_{2}>\mathrm{COS}+2 \mathrm{CO}_{2} & \mathrm{X}_{\mathrm{CO}}=0.9995 \\
& \mathrm{H}_{2}+0.5 \mathrm{~S}_{2} \rightarrow \mathrm{H}_{2} \mathrm{~S} & \mathrm{X}_{\mathrm{H} 2}=0.01 \\
& & \\
\text { DSRP2 } & \mathrm{SO}_{2}+2 \mathrm{COS} \rightarrow 1.5 \mathrm{~S}_{2}+2 \mathrm{CO}_{2} & \mathrm{X}_{\mathrm{COS}}=0.9999
\end{array}
$$

SN-EQUIL establishes the allotropic distribution of elemental sulfur using a Gibbs Free Energy calculation. Including this block more accurately models the heat generated inside the DSRP Reactor.

$$
\begin{array}{llll}
\text { SN-EQUIL } & 4 \mathrm{~S}_{2} \rightarrow \mathrm{S}_{8} & \mathrm{X}_{\mathrm{S} 2}=0.23 \\
& 3 \mathrm{~S}_{2} \rightarrow \mathrm{S}_{6} & \mathrm{X}_{\mathrm{S} 2}=0.32
\end{array}
$$

1.c. PRESAIR - DSRP

The transport reactor design for the regenerator in the DSRP - base HGD process model allows the use of undiluted air ("neat air") to regenerate the desulfurization sorbent. Introducing air at the required pressure can be accomplished using either an axial-flow or centrifugal compressor. In most applications, including this process simulation, it is preferable to use a centrifugal compressor. Centrifugal compressors have the advantage of a larger operating range (Dimoplom). Centrifugal compressors typically operate below $225^{\circ} \mathrm{C}$ (Brown; Dimoplon) in order to avoid equipment damage. 
The large increase in pressure (ambient to $275+$ psia) in the PRESAIR air compressor generates a considerable temperature rise. Interstage cooling, between the compressor's 6 stages, is necessary to maintain an air temperature below $225^{\circ} \mathrm{C}$ and to prevent mechanical damage to the compressor (Brown; Dimoplon). The temperature increase across the first stage does not require cooling stage 1 effluent and there is no need to cool the effluent of the final stage as well. Therefore, there will be four interstage coolers needed for the six-stage compressor. Pressure drop during interstage cooling can be approximated as $2 \%$ of the pressure entering the cooler or 2 psia, whichever is larger (Brown). For pressuring to 280 psia estimating a 2 psia drop for each cooler is reasonable; these pressure losses are included in the ASPEN PLUS compressor block calculations.

Significant capital will be spent on the purchase of an air compressor. Increasing pressure to $280 \mathrm{psia}$ for an feed of $8,800 \mathrm{ft}^{3} / \mathrm{min}$ (DSRP base case) requires a compressor made of steel as opposed to cast iron (Bloch). Compressors made of low value steel should be both mechanically durable and economical. For simplicity, the cost estimates in this report assume electric drive.

Steam turbines could drive the compressors. Steam turbines are historically the most popular means of driving centrifugal compressors. They have the ability to operate over a wide speed range. Electric motors have experienced increasing favor due to a typically lower operating cost. Buying electricity is more economical than small scale steam generation for a specific piece of equipment (Brown). However, with the desulfurization processes generating steam and with steam available from the power plant, a steam turbine may be the best means of driving the compressors.

\section{Air Compressor Costs}

Compressor costs were determined from a budgetary quotation obtained from IngersollRand. Ingersoll-Rand stated a cost of $\$ 241,000$ for the Centac Model 2CV23M3EEPF. This model Centac is a centrifugal air compressor (drive and motor) capable of raising 2,250 acfm to 
280 psia. Extrapolation was used to determine the cost of compressors needed for the different flow rates. Figures in Peters and Timmerhaus (1991) were used to determine the rate at which compressor costs change with varying flow rates.

The compressor, PRESAIR, is modeled as a six stage compressor. It has been assumed that the interstage coolers lower the air temperature to $115^{\circ} \mathrm{C}$. Calculation of stage efficiency was performed using a procedure outlined in Brown (1986). The polytropic efficiencies calculated range from 0.65 to 0.787 , which are consistent with other values found in literature (Brown; Dimoplon). PRESAIR pressurizes 8,800 acfm (in the DSRP base case); for such a flow ASPEN predicts a 3,280 HP power requirement. Directly scaling up the Centac (2,250 acfm, 800 HP) compressor predicts a 3,130 HP power requirement. The similar horsepower requirements suggest that ASPEN is realistically simulating the air compressor.

\section{1.d. RECYCOMP - DSRP}

The compressor RECYCOMP repressurizes the vapor stream leaving the sulfur condenser (the tailgas of the DSRP reaction) and sends it back to the desulfurization reactor. Recycling this stream eliminates an emissions stream while causing a minor load increase for the reactor network. The pressure increase between the condenser and the desulfurization reactor should be within the capabilities of a single stage centrifugal compressor, and RECYCOMP was modeled as such.

\section{1.e. High Pressure Condenser - DSRP}

The High Pressure Condenser condenses sulfur out of the DSRP Reactor effluent stream. It is high pressure in the sense that it operates near the pressure of the DSRP Reactor. Reducing the temperature to $140^{\circ} \mathrm{C}$ condenses the sulfur. At this temperature, the vast majority of sulfur condenses, and there is no risk of freezing. 
The High Pressure Condenser is simulated using two blocks (Figure 2). The first, COND-I, is an equilibrium block that establishes equilibrium between $S_{2}$ and $S_{8}$. At high temperatures like those in the DSRP reactor, sulfur is predominately in the $\mathrm{S}_{2}$ form (Barnett; Chen; Cotton). At the cooler condensation temperatures, the $S_{8}$ and $S_{6}$ sulfur species predominate. The second block, COND-II, establishes equilibrium between the $\mathrm{S}_{8}$ and $\mathrm{S}_{6}$ sulfur species and phase equilibrium. The $\mathrm{S}_{8}$ and $\mathrm{S}_{6}$ sulfur species are easier to condense. Calculation of the sulfur equilibrium, in addition to more accurately simulating the phase equilibrium, also increases the accuracy of the heat transfer requirements. The low temperature in the condenser makes it unsuitable for the direct production of high pressure steam. The condenser could be used to preheat the feedwater to other steam-generation units (Appendix F).

\section{1.f. VAPORIZR - DSRP}

Reducing the sulfur product stream's pressure to ambient will cause the water present in the stream to vaporize. The vaporizing water can cool the sulfur stream enough to cause freezing. The VAPORIZR accomplishes three tasks: a) it reduces sulfur pressure to ambient; $b$ ) it supplies heat to the sulfur stream so that the temperature will be maintained at $140^{\circ} \mathrm{C}$ and sulfur will remain molten; and, c) it also helps purify the product stream by removing water from the sulfur.

\section{1.g. PD-COOLR - DSRP}

Prior to entering the condenser, the DSRP Reactor effluent ("RXNPRD") is sent through the Product Cooler (PD-COOLR) heat exchanger. Cooling the reactor products in this heat exchanger reduces the condenser heat duty and PD-COOLR operates at temperatures suitable for generating high pressure steam. Sulfur condensation inside the PD-COOLR should be avoided. Condensation would create the undesirable situation of two phase flow and would require removing the sulfur during shutdown so that it will not freeze inside the heat exchanger. Operating the PD-COOLR above the product stream's dew point would prevent sulfur condensation. Dew point calculations were made for the various reactor effluent distributions. 
The allotropic sulfur distribution $\left(\mathrm{S}_{2}, \mathrm{~S}_{6}, \mathrm{~S}_{8}\right)$ changes with temperature, however the speed at which equilibrium is reached is unknown. It is not known how closely sulfur allotrope distribution will approach equilibrium in the cooler. Therefore, calculations were made for the dew point temperatures at both the equilibrium distribution of sulfur allotropes, and at the allotrope distribution that leaves the reactor (Table 6).

For the simulations, the PD-COOLR was defined to cool reaction products to $415^{\circ} \mathrm{C}$. Table 6 shows that at $415^{\circ} \mathrm{C}$ sulfur condensation will not occur if the sulfur allotrope equilibrium is reached instantaneously (Sulfur Equilibrium = yes) and also will not occur if the sulfur allotrope distribution is still at the DSRP Reactor temperature distribution (Sulfur Equilibrium = no).

Table 6: Dew Point Temperatures for DSRP Product Distributions

\begin{tabular}{|c|c|c|c|}
\hline Product distribution & \multicolumn{1}{c}{ Sulfur Equilibrium } & \multicolumn{1}{c|}{ Pressure (psia) } & Temperature $\left({ }^{\circ} \mathrm{C}\right)$ \\
\hline DSRP & yes & 275 & 360 \\
\hline DSRP & no & 275 & 405 \\
\hline DSRP-b & yes & 275 & 357 \\
\hline DSRP-b & no & 275 & 402 \\
\hline DSRP-c & yes & 275 & 362 \\
\hline DSRP-c & no & 275 & 406 \\
\hline
\end{tabular}

1.h. AIR-HX - DSRP

The AIR-HX heat exchanger utilizes the hot regenerator off gas ("ROG") stream to raise the temperature of the high pressure air stream ("P-O2-N2"). Heating the air is required to achieve a sufficiently high temperature to initiate the regeneration reaction. Cooling the ROG reduces the heat removal required to keep the DSRP reactor at $600^{\circ} \mathrm{C}$. The hot (above $800^{\circ} \mathrm{C}$ ) ROG stream contains $\mathrm{SO}_{2}$. The presence of hot $\mathrm{SO}_{2}$ requires that the AIR-HX heat exchanger tubes be constructed from type 310 stainless steel (SS 310). 


\section{AHGP Equipment}

The AHGP consists of a desulfurization transport reactor and a 3-stage bubbling bed regeneration reactor. The reactions that remove sulfur from coal gas (Reactions 5 and 6) proceed in the desulfurization reactor. In the regenerator the sorbent is regenerated with $\mathrm{SO}_{2}$, to generate elemental sulfur (reaction 7), and is subsequently regenerated with $\mathrm{O}_{2}$ to produce $\mathrm{SO}_{2}$ (reactions $8 \& 9$ ). Forming elemental sulfur during regeneration eliminates the need a for third reactor, as the DSRP based process requires. Other major pieces of equipment in the AHGP include compressors, condensers, a demister, and heat exchangers.

\section{2.a. Desulfurization and Regeneration Reactors - AHGP}

There are several differences between the AHGP desulfurization and regenerator reactor designs (Figure 6) and those envisioned for the DSRP -based process (Figure 5). For example, in the AHGP sorbent descends counter-currently against the rising $\mathrm{SO}_{2}$ in the regeneration reactor. Sorbent descending through the regenerator makes it necessary to re-elevate sorbent into a standpipe located upstream of the desulfurization reactor. A heat exchanger in the standpipe enables cooling of the sorbent before it re-enters the desulfurization reactor.

The top stage of the regenerator (HX-STAGE, Figure 3) heats the entering sorbent by direct contact with the exiting $\mathrm{SO}_{2}$ stream. The second stage of the regenerator is modeled with REGEN2 and S-REGEN2. REGEN2 models the following equilibrium reaction:

$$
3 \mathrm{SO}_{2}+4 \mathrm{FeS}=7 / 2 \mathrm{~S}_{2}+2 \mathrm{Fe}_{2} \mathrm{O}_{3}
$$

This equilibrium reaction is modeled with an RSTOICH block, assuming a 0.667 fractional conversion of FeS. An RSTOICH block is used due to the difficulty of balancing $\mathrm{SO}_{2}$ consumption and generation. As discussed earlier in the report (Section II.4), assuming a 0.667 
Figure 6: Schematic of AHGP Desulfurization and Regeneration Reactors

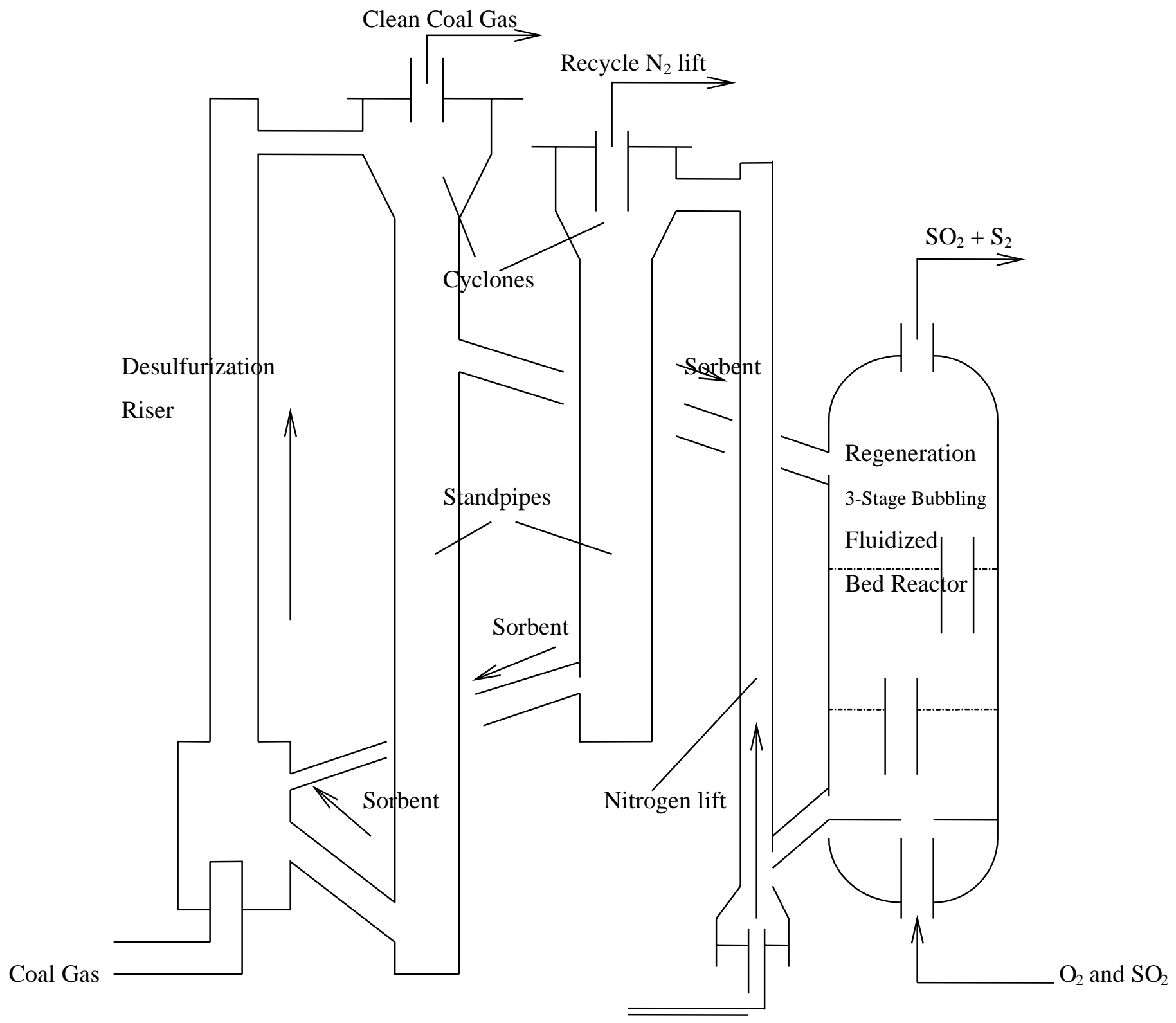


fractional conversion may be an optimistically high assumption. If so, more Fe will need to be circulated to make up for the discrepancy. The S-REGEN2 block establishes the equilibrium distribution of sulfur allotropes.

The bottom stage is modeled with the REGEN1 and S-REGEN1 blocks. Oxygen feed to REGEN1 oxidizes the sorbent. Although there is $\mathrm{SO}_{2}$ present in large quantities in REGEN1, it is assumed not to oxidize any sorbent. Equilibrium conversion for $\mathrm{SO}_{2}$ oxidation is assumed to be reached in the second stage. Any unreacted FeS present in the sorbent coming from the second stage is expected to react very quickly with oxygen present (reactions $17 \& 18$ ). The $\mathrm{ZnS}$ is expected to regenerate less rapidly than the iron compound. Uncondensed sulfur recycling back to REGEN1 will quickly oxidize. These reactions are modeled to occur in the following order:

$$
\begin{aligned}
& \mathrm{S}_{8}+8 \mathrm{O}_{2}-->8 \mathrm{SO}_{2} \\
& \mathrm{~S}_{6}+6 \mathrm{O}_{2-->} 6 \mathrm{SO}_{2} \\
& 2 \mathrm{FeS}+3.5 \mathrm{O}_{2}-->\mathrm{Fe}_{2} \mathrm{O}_{3}+2 \mathrm{SO}_{2} \\
& \mathrm{ZnS}+1.5 \mathrm{O}_{2}->\mathrm{ZnO}+\mathrm{SO}_{2}
\end{aligned}
$$

The bottom stage is simulated to operate with all oxygen being consumed in REGEN1, and a small portion of $\mathrm{ZnS}$ remaining unoxidized.

More than one regeneration reactor maybe used in parallel for the AHGP. Sizing the reactor (Appendix I) revealed that to achieve the desired superficial velocity for removing the larger sulfur quantities requires undesirably large reactor diameters $(25+\mathrm{ft})$. The larger reactor diameters will require thicker reactor walls $(4.5+$ in) to contain the high pressures. Reactors in parallel reduce reactor diameter and the required wall thickness resulting in less steel required. A maximum reactor diameter of 13 feet was the guideline used during sizing. The 3-stage regenerator heights were set at 45 feet. It is expected that $5 \mathrm{ft}$ will be needed for the heat exchanging stage, $10 \mathrm{ft}$ for the middle stage, and $2.5 \mathrm{ft}$ for the bottom stage. The rest of the reactor height will be used for phase separation. 
The equations used for sizing and costing the AHGP desulfurization and regeneration transport reactor system are described in Appendix G-Calculation of Reactor Size. The actual calculations can be found in Appendix I-Sizing Reactors for the AHGP.

\section{2.b. LIFTCOMP - AHGP}

The AHGP desulfurization - regeneration transport reactor system requires a means of elevating the sorbent exiting the regeneration reactor. This will be accomplished using a nitrogen lift (Figure 3 and Figure 6). LIFTCOMP increases the pressure of the nitrogen recycle before it enters the nitrogen lift. A cyclone and filters placed upstream of LIFTCOMP and N2COOLR will prevent sorbent from damaging the compressor.

\section{2.c. $S O 2-C O M P$ - $A H G P$}

SO2-COMP recompresses the $\mathrm{SO}_{2}$ loop. It is advantageous to recompress the $\mathrm{SO}_{2}$ loop after the condenser because the lower gas temperature will increase the compressor efficiency and reduce wear on the compressor. The pressure increase required will be obtainable using a single stage centrifugal compressor.

\section{2.d. $C O N-C O M P$ - $A H G P$}

The CON-COMP compressor is used to reintroduce the $\mathrm{SO}_{2}$ that vaporizes when the sulfur stream is reduced to ambient pressures (LP-COND, Figure 3). The small flow rate means a single stage reciprocating compressor can be used to pressure the $\mathrm{SO}_{2}$ stream. The pulsing flow of $\mathrm{SO}_{2}$ coming from CON-COMP will not have a significant effect on the large $\mathrm{SO}_{2}$ loop. 
The condenser, COND-EQ, cools down the $\mathrm{SO}_{2}$ loop so that sulfur can be condensed out. The stream temperature is reduced to $140^{\circ} \mathrm{C}$, and sulfur distribution is established in COND-EQ. It was initially intended that sulfur equilibrium would be calculated using a REQUIL block; however, this caused convergence problems. Using the RSTOIC block eliminates the convergence problem and does not compromise the validity of the results. The sulfur equilibrium distribution was determined in a separate simulation.

$$
\begin{array}{lll}
4 \mathrm{~S}_{2}->\mathrm{S}_{8} & \mathrm{X}_{\mathrm{S} 2}=0.98 \\
3 \mathrm{~S}_{2-}->\mathrm{S}_{6} & \mathrm{X}_{\mathrm{S} 2}=0.02
\end{array}
$$

The large vapor stream containing a small volume of molten sulfur will make a demister necessary to isolate the small liquid flow.

\section{2.f. DEMISTR - AHGP}

The large gas stream of $\mathrm{SO}_{2}$ will suspend the relatively small flow of condensed sulfur. The demister (DEMISTR) will be necessary for collecting the sulfur. The liquid sulfur accounts for $8 \mathrm{wt} \%$ of the stream ("IN-COND"), but only 0.1 vol\% of the $\mathrm{SO}_{2}$ - sulfur flow.

\section{2.g. $L P-C O N D-A H G P$}

Sulfur leaving the demister needs to be brought to ambient pressure for storage. This can be accomplished in a flash tank (LP-COND, Figure 3). The pressure drop vaporizes much of the $\mathrm{SO}_{2}$ that co-condenses with the sulfur. The temperature drop caused by $\mathrm{SO}_{2}$ vaporization is not enough to freeze the sulfur. Vaporizing off the $\mathrm{SO}_{2}$ decreases the sulfur stream temperature to $127^{\circ} \mathrm{C}$, well above the melting temperature of sulfur $\left(114^{\circ} \mathrm{C}\right)$. The volumetric flow of $\mathrm{SO}_{2}$ vaporized is 47 times larger than the condensed sulfur flow. The tank should contain a demister pad or some other separation device to prevent sulfur from being entrained with the $\mathrm{SO}_{2}$ vaporized. 


\section{2.h. HEATX - AHGP}

The HEATX heat exchanger transfers heat from the warm regenerator effluent $\left(\mathrm{SO}_{2}\right.$ and sulfur) to preheat the cool regenerator feed stream of recycled $\mathrm{SO}_{2}$ and oxygen. Sulfur condensation in the heat exchanger should be avoided. If sulfur condenses, the system would have to handle two phase flow from HEATX to the condenser. Shutdown procedures would also require removing sulfur from the heat exchanger to prevent sulfur from freezing inside. Assuming the sulfur allotrope distribution is at equilibrium when condensation occurs, the $\mathrm{SO}_{2}$ sulfur stream's dew point is $310^{\circ} \mathrm{C}$. Cooling the $\mathrm{SO}_{2}$ - sulfur stream to no lower than $315^{\circ} \mathrm{C}$ should prevent condensation from occurring.

\section{2.i. N2-COOLR - AHGP}

The N2-COOLR cools the nitrogen stream prior to its recompression in LIFTCOMP. Cooling the stream decreases the power required for recompression and reduces the possibility of damaging the compressor. The cool nitrogen stream contributes to reducing the temperature of sorbent feed to the desulfurization reactor. Sorbent entering the compressor would cause damage. Therefore, filters should be installed upstream of the compressor. The filters will also be placed upstream of the heat exchanger (N2-COOLR) to prevent build up of sorbent in the heat exchanger.

\section{2.j. RCYHEATR - AHGP}

The RCYHEATR was incorporated to ensure that the $\mathrm{SO}_{2}$ - oxygen feed to the regenerator would be hot enough to initiate the regeneration reactions. Superheated steam is used to raise the $\mathrm{SO}_{2}$ - oxygen stream temperature, as the separate steam generation process flow sheets show (Appendix F). RCYHEATR works with the HEATX heat exchanger to raise the $\mathrm{SO}_{2}$ - oxygen stream temperature above $400^{\circ} \mathrm{C}$. The RCYHEATR is needed because, HEATX heat transfer is limited to insure no condensation occurs upstream of the condenser. 


\section{PARAMETRIC STUDIES}

Parametric studies were performed to determine how HGD requirements were affected by various coal gas feeds. Inlet $\mathrm{H}_{2} \mathrm{~S}$ concentrations were varied to simulate variation in sulfur content with different types of coal. Therefore, $\mathrm{H}_{2} \mathrm{~S}$ concentrations will vary between plants using different coal sources. The effect of power generation capacity was also simulated. Finally, different oxygen sources (air vs. pure oxygen) were investigated. Flow sheets and stream summaries for variations of both processes can be found in appendix $\mathrm{H}$.

\section{1. $\underline{\mathrm{H}}_{2} \underline{\mathrm{S}}$ Inlet Concentration}

DSRP and AHGP simulations were performed using a base case coal gas feed containing $0.85 \mathrm{~mol} \% \mathrm{H}_{2} \mathrm{~S}$ and a base case power production of 260 megawatts, after sulfur removal. Additional simulations were performed to determine the effect of $\mathrm{H}_{2} \mathrm{~S}$ inlet concentration on the amount of coal gas that had to be produced. Table 7 shows how varying $\mathrm{H}_{2} \mathrm{~S}$ inlet concentration requires increasing the gasification of coal to maintain $260 \mathrm{MW}$ generation.

Table 7: Coal Gas Fed to and Consumed by HGD for Various $\mathrm{H}_{2} \mathrm{~S}$ Concentrations

\begin{tabular}{lllcc} 
Simulation & $\begin{array}{l}\mathrm{H}_{2} \mathrm{~S} \text { inlet } \\
\text { conc. }(\mathrm{mol} \%)\end{array}$ & $\begin{array}{l}\text { Coal Gas } \\
\mathrm{Fed}(\mathrm{lb} / \mathrm{hr})\end{array}$ & $\begin{array}{c}\text { Consumed } \\
\mathrm{H}_{2}(\mathrm{lb} / \mathrm{hr})\end{array}$ & $\begin{array}{c}\text { Consumed } \\
\mathrm{CO}(\mathrm{lb} / \mathrm{hr})\end{array}$ \\
\hline DSRP & 0.85 & 460,000 & 320 & 6,000 \\
DSRP-b & 2.50 & 501,000 & 1,000 & 19,000 \\
DSRP-c & 0.25 & 447,000 & 90 & 1,700 \\
AHGP & 0.85 & 450,000 & 160 & 0 \\
AHGP-b & 2.50 & 468,000 & 470 & 0 \\
AHGP-c & 0.25 & 444,000 & 46 & 0
\end{tabular}

The sulfur concentration has a profound effect on DSRP flow requirements because of the coal gas slipstream used in the DSRP reactor. The coal gas slipstream increases as the amount of sulfur converted in the DSRP reactor increases. 
The small increase in required coal gas for the AHGP can be attributed to the consumption of $\mathrm{H}_{2}$ in the desulfurization reaction:

$$
\mathrm{Fe}_{2} \mathrm{O}_{3}+2 \mathrm{H}_{2} \mathrm{~S}+\mathrm{H}_{2}-->2 \mathrm{FeS}+3 \mathrm{H}_{2} \mathrm{O}
$$

The higher sulfur concentrations also require more sorbent circulation to dissipate the heat evolved during reactions. Increased sulfur concentrations require larger reactors. Increasing sulfur also increases the heat removal requirements.

\section{Power Generation}

Parametric studies were performed to determine the influence of power plant capacity; power generation is $260 \mathrm{MW}$ in the base case. Inlet flows were altered to generate $110 \mathrm{MW}$ and $540 \mathrm{MW}$. The power level adjustments resulted in flow rates and energy transfer that both scale directly with the change in power generation. The effect of the varying coal gas feed rate was similar to the effect of changing $\mathrm{H}_{2} \mathrm{~S}$ feed concentrations. An economic comparison shows that the process costs depend on the total sulfur removal requirements. Variations in the flow rates of the other coal gas components do not have a significant effect on the HGD.

\section{Pure Oxygen vs. Air Oxidation}

Sulfur is removed from the coal gas stream by the reaction of $\mathrm{H}_{2} \mathrm{~S}$ with the active components of the sorbent to form metal sulfides. Regenerating the sorbent allows it to be reused for removing more sulfur. Sorbent regeneration occurs by exposing the sulfurized sorbent to an oxidizing environment. Pure oxygen and air are both capable of performing the oxidation. Implications of using oxygen and air follow.

\section{3.a. $D S R P$}

Pure oxygen is an impractical oxidizing medium for sorbent regeneration. In the DSRP based process, regenerating with pure oxygen would result in such high temperatures that the sorbent would sinter. By comparison, the nitrogen present in air dilutes the oxygen and serves as 
a heat sink for the highly exothermic regeneration reactions. What is not intuitively obvious is that it is more expensive to supply air to the system than to supply oxygen. For DSRP - based process conditions it is more expensive to compress air than to separate oxygen and then compress only the oxygen (Hvizdos).

\section{3.b. $A H G P$}

Air is not a viable oxidizing medium for use in the Advanced Hot Gas Desulfurization Process. The use of air would require separating nitrogen from sulfur dioxide. The AHGP process has a large $\mathrm{SO}_{2}$ stream that circulates through the regeneration reactor and the sulfur condenser. In the AHGP, oxygen enters the $\mathrm{SO}_{2}$ loop as a pure oxygen feed and leaves with the sorbent. Sulfur enters the $\mathrm{SO}_{2}$ loop on the sorbent and leaves as condensed sulfur. Feeding air instead of oxygen would provide a steady flow of nitrogen into the $\mathrm{SO}_{2}$ loop. Maintaining steady state would require removing nitrogen at the rate it is introduced.

The concept of adding a condenser to the $\mathrm{SO}_{2}$ loop was investigated for separating nitrogen from $\mathrm{SO}_{2}$ (Figure 7). ASPEN simulations were performed to determine the condenser conditions necessary for removing nitrogen at the rate it enters the system. The idea was to condense the $\mathrm{SO}_{2}$ in the loop and vent only nitrogen. Table 8 shows that this concept is impractical. When the ratio of $\mathrm{SO}_{2}: \mathrm{N}_{2}$ is large the $\mathrm{SO}_{2}$ is more prone to condense. This can be seen in table 8 where for the same temperature and pressure, uncondensed $\mathrm{SO}_{2}\left(\mathrm{SO}_{2}\right.$ vented) decreases as the mass fraction of $\mathrm{SO}_{2}$ increases. Therefore, the most efficient condenser will have the minimum amount of $\mathrm{N}_{2}$ feed to it. The minimum $\mathrm{N}_{2}$ fed to the condenser will be equal to the rate at which nitrogen enters the system via the air steam. The minimum corresponds to a case where no $\mathrm{N}_{2}$ condenses ( $\mathrm{N}_{2}$ unpurged). Table 8 shows that even with the very low $\mathrm{N}_{2}$ concentration there is an unreasonable amount of $\mathrm{SO}_{2}$ vented. 
Figure 7: Condenser for Removal of Nitrogen

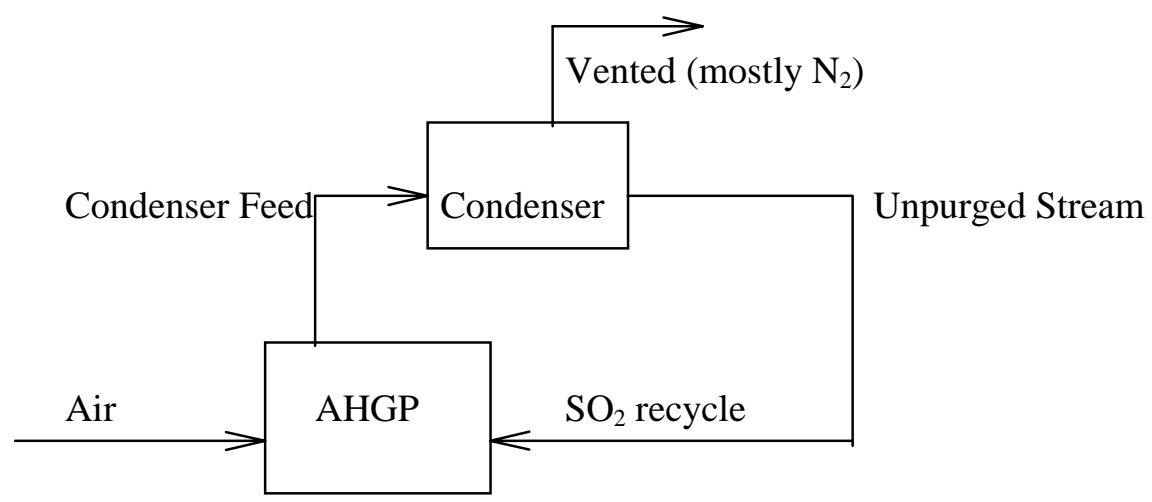

The simulations assumed that the total $\mathrm{SO}_{2}$ loop flow would be $260,000 \mathrm{lbs} / \mathrm{hr}$ and $13,500 \mathrm{lbs} \mathrm{N}_{2} / \mathrm{hr}$ would need to be removed.

Table 8: $\mathrm{N}_{2}$ Removal at Various $\mathrm{N}_{2}$ Concentrations, Condenser Temperatures and Pressures

$\begin{array}{cccccc}\begin{array}{c}\text { Condenser } \\ \text { Fed: } \mathrm{SO}_{2}\end{array} & \begin{array}{c}\text { Condenser } \\ \text { Pressure }\end{array} & \begin{array}{c}\text { Condenser } \\ \text { Temperature }\end{array} & \begin{array}{c}\mathrm{N}_{2} \text { unpurged } \\ (\mathrm{lbs} / \mathrm{hr})\end{array} & \begin{array}{c}\mathrm{SO}_{2} \text { vented } \\ (\mathrm{lbs} / \mathrm{hr})\end{array} & \begin{array}{c}\mathrm{N}_{2} \text { vented } \\ (\mathrm{lbs} / \mathrm{hr})\end{array} \\ \begin{array}{c}\text { (psia) } \\ 0.100\end{array} & \begin{array}{c}\left.{ }^{\circ} \mathrm{C}\right) \\ 0.900\end{array} & 50 & 0 & 26,000 & 234,000 \\ 0.946 & 275 & 50 & 418 & 58,200 & 25,600 \\ 0.946 & 400 & 50 & 511 & 30,800 & 13,500 \\ 0.940 & 275 & -20 & 1,010 & 16,800 & 13,000 \\ & 275 & 716 & 1,540 & 14,900\end{array}$

Furthermore, nitrogen is not needed as a heat sink in the AHGP. The $\mathrm{SO}_{2}$ stream is a sufficient gas phase heat sink to carry away the heat of the regeneration reaction. The economic analysis showed it is actually desirable to feed oxygen instead of air. The cost of compressing air is higher than the cost of separating out oxygen and then compressing only the oxygen. 


\section{ADDITIONAL PROCESS CONSIDERATIONS}

\section{Steam Generation}

The coal gas desulfurization with sulfur production overall process is exothermic. DSRP and AHGP both require heat removal for condensation and to maintain reaction temperatures. The heat removal requirements create the opportunity to generate high pressure steam that could drive plant equipment or be incorporated into the plant's power generation steam cycle.

Steam generation has been modeled as a closed loop. Steam is generated by removing heat from the desulfurization process. The steam is then utilized, by undefined means, condensed, cooled and the condensate is reused. Cooling tower water is used to cool the steamcondensate loop (Figure 8). There are benefits to having a self-contained loop for steam production. First, it makes it easy to maintain steam-condensate purity, which reduces fouling and corrosion. It also allows for higher cool water feed temperatures $\left(\sim 90^{\circ} \mathrm{C}\right)$, which increases steam production.

Figure 8: Schematic for HGD Steam Generation

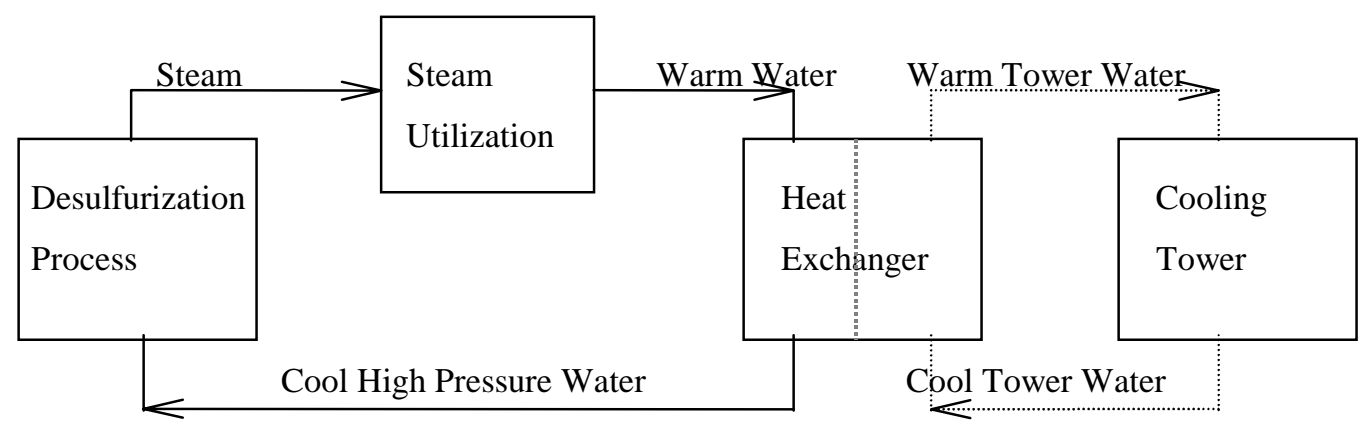

The steam generated from the HGD process was assumed to be at 950 psia and $441{ }^{\circ} \mathrm{C}$ (Appendix F). Since desulfurization would be incorporated into a larger power generating plant, it is not possible to discern the most useful steam conditions without knowledge of the power generation facility. It is likely that steam generated from the HGD would be utilized by existing power plant equipment. Since the end use of the steam generated is unknown a generic dollar 
credit for the steam generated was used for the economic analysis. Peters and Timmerhaus (1991) state that 500 psig steam was worth $\$ 0.0039 / \mathrm{lb}$ in 1990 ; this value was used during the economic assessment. The benefit calculated should be a conservative value since the simulated steam produced is at a higher pressure (950 psia) and the economic calculations use 1996 as a basis. However, another source notes that for $900 \mathrm{psi}$ and $441^{\circ} \mathrm{C}$ steam, $1 \mathrm{kWh}$ power generation can be expected per 22.44 pounds of steam (Noyes). The economic credit from the conversion of steam to power according to this relationship was less than the credit obtained using the Peters and Timmerhaus relationship. Since the Peters and Timmerhaus credit value is conservative and still predicts a larger benefit, the Peters and Timmerhaus value was used.

\section{Material of Construction}

Type 310 stainless steel $(25 \% \mathrm{Cr}-20 \% \mathrm{Ni})$ should be used for the construction of equipment that contacts sulfur species. Type 310 stainless steel (SS 310) will be more durable than type 316 stainless steel (SS 316) (17\% Cr - 8\% Ni - 2\%Mo). Higher chromium content gives SS310 greater oxidation resistance, and the higher nickel concentration gives improved resistance to carburization (EPRI). Cost data for SS310 is not contained in ASPEN so SS316 material cost factors were used.

\section{Sulfur Storage}

Transporting molten sulfur is preferred over solid sulfur. Liquid sulfur is easier to transport and reduces handling losses. It will be necessary to store the molten sulfur before it is shipped out by train. The storage tank should be capable of storing several days worth of recovered sulfur. It should also be equipped with a heat exchanger to keep sulfur molten. The costs of the sulfur storage tanks were calculated using ASPEN assuming SS 310 was used to construct storage for seven days of sulfur production (SS 316 was entered in ASPEN due to lack of data for SS 310). 


\section{Process Operation}

The DSRP should be the easier process to operate. Balancing the $\mathrm{SO}_{2}$ production and consumption in the AHGP appears to be particularly difficult. The difficulty arises from the reaction of $\mathrm{FeS}$ with $\mathrm{SO}_{2}$ to form elemental sulfur. The reaction's equilibrium varies significantly with temperature. If the reactants are too thermodynamically favored, less $\mathrm{SO}_{2}$ will be consumed than expected. However, $\mathrm{SO}_{2}$ production will remain constant (sorbent oxidation being driven to completion by oxygen). Thus, if the reaction:

$$
3 \mathrm{SO}_{2}+4 \mathrm{FeS}<==>7 / 2 \mathrm{~S}_{2}+2 \mathrm{Fe}_{2} \mathrm{O}_{3}
$$

does not reach design conversions, $\mathrm{SO}_{2}$ flow will increase and sulfurized sorbent will be returned to the desulfurization reactor. With $\mathrm{SO}_{2}$ already present in great excess the increased $\mathrm{SO}_{2}$ flow will not significantly shift equilibrium towards the products.

It is recommended that the AHGP be operated at conditions that will cause a net consumption of $\mathrm{SO}_{2}$. Replenishing depleted $\mathrm{SO}_{2}$ levels can easily be accomplished by increasing the oxygen feed. Excess oxygen will convert elemental sulfur into $\mathrm{SO}_{2}$.

Preventing the build up of impurities in the $\mathrm{SO}_{2}$ loop contributes to the complexity of the AHGP. Venting a portion of the loop is undesirable since it contains mostly $\mathrm{SO}_{2}$. Venting would release $\mathrm{SO}_{2}$, emissions the system is designed to eliminate. Operating the AHGP requires determining the rate at which impurities build up in the recycle loop and the appropriate purge stream for the rate of build up. The purge stream should be fed to the desulfurization reactor, reducing the release of $\mathrm{SO}_{2}$. 


\section{ECONOMIC ANALYSIS}

\section{Capital Expenditures}

The AHGP requires more capital investment than the DSRP. Reactors account for over half of the capital investment. The higher cost of AHGP reactors results in an higher overall capital investment necessary for the AHGP (Figure 9). The majority of equipment was costed using ASPEN. Equipment costed by ASPEN has a purchase date set at June, 1996. Equipment contacting sulfur will experience less corrosion when constructed of stainless steel 310 (SS310). Since ASPEN lacks material of construction correction factors for SS310, SS316 values were used. While the majority of equipment was costed using ASPEN, the equipment that comprises the majority of the capital expenditures, such as the reactors, were estimated by other means.

The reactor costs were calculated using a procedure outlined in Peters and Timmerhaus (1991). The reactor costs were determined using the amount of steel required for their construction. The procedure is described in appendix G, and the calculations are contained in appendix $\mathrm{H}$ and appendix I. The reactor cost includes the cost of installation.

Another piece of equipment not costed by ASPEN is the PRESAIR - air compressor used in the DSRP. PRESAIR costs were determined by scaling a price quote for the Ingersoll-Rand Centac air compressor. The Centac Model 2CV23M3EEPF, capable of raising 2,250 acfm to 280 psia, was quoted at $\$ 241,000$. Extrapolation was used in determining the cost of compressors needed for the different flow rates. Figures in Peters and Timmerhaus (1990) were used to determine the rate at which compressor costs change with varying flow rates. 


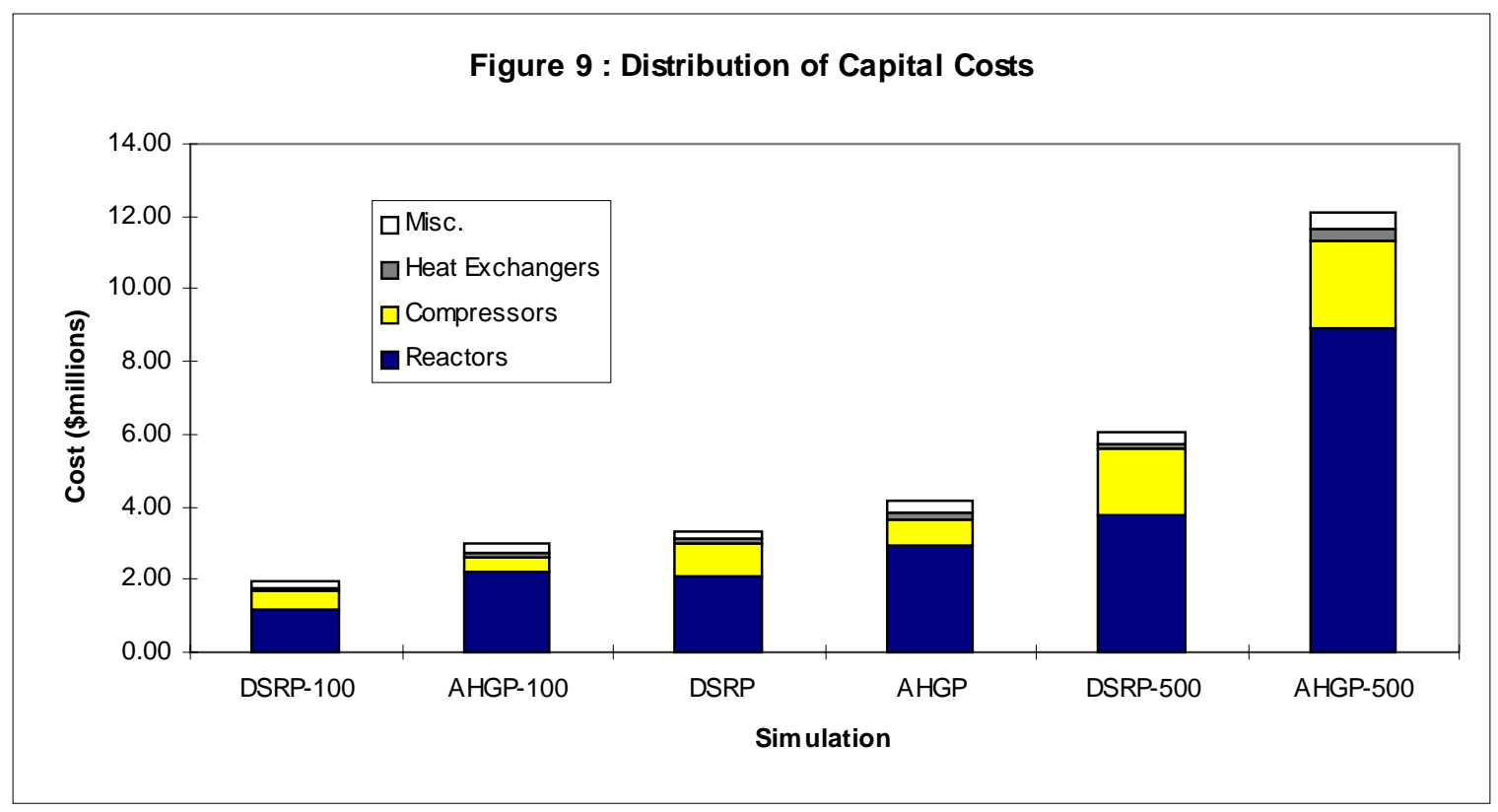

There are additional capital costs not included in this report, two of which, piping costs and sorbent/catalyst costs, will probably be significant. There will be other expenses, like additional office space for employees, which are site dependent. The site dependent expenses should not have an significant effect on the total capital investment calculations. At this stage of investigation the piping and sorbent/catalyst cost are assumed identical for both HGD process. If this assumption is valid than a comparison of the overall capital costs for the AHGP and the DSRP will not be affected by their absence.

\section{Yearly Operating Costs}

The AHGP has a lower yearly operating cost than the DSRP. Figures 10 and 11 show the distribution of the major yearly expenditures for both processes. 

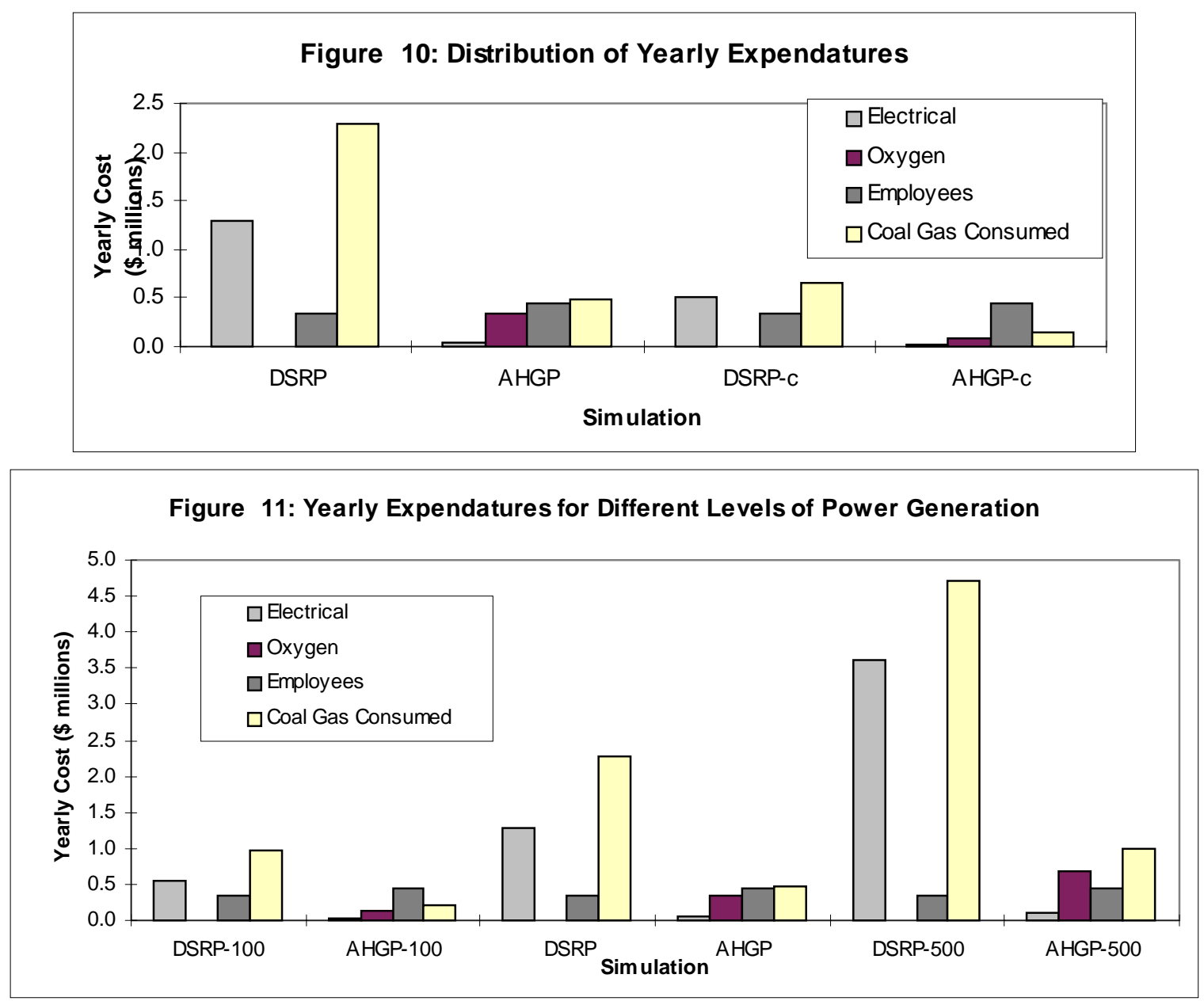

The bases cases (DSRP and AHGP) have coal gas feeds containing $0.85 \mathrm{~mol} \% \mathrm{H}_{2} \mathrm{~S}$ and produce $260 \mathrm{MW}$. Most of the yearly expenditures decline as the amount sulfur in the coal gas is decreased (DSRP-c and AHGP-c have feeds containing $0.25 \mathrm{~mol}_{2} \mathrm{H}_{2} \mathrm{~S}$ ). The exception is the yearly costs of additional employees, which have been assumed to be dependent on the complexity of the HGD process and not its size. As the sulfur concentration decreases both the absolute expenditure difference (DSRP cost - AHGP cost) and the relative expenditure difference ([DSRP cost - AHGP cost] / AHGP cost) decrease. This decrease indicates that the competitive advantage of the AHGP is smaller for cleaning a coal gas stream containing a low $\mathrm{H}_{2} \mathrm{~S}$ concentration. The same trend exists comparing the economics of different levels of power generation: the AHGP's yearly economic advantage over the DSRP declines as the overall power generation is decreased. 

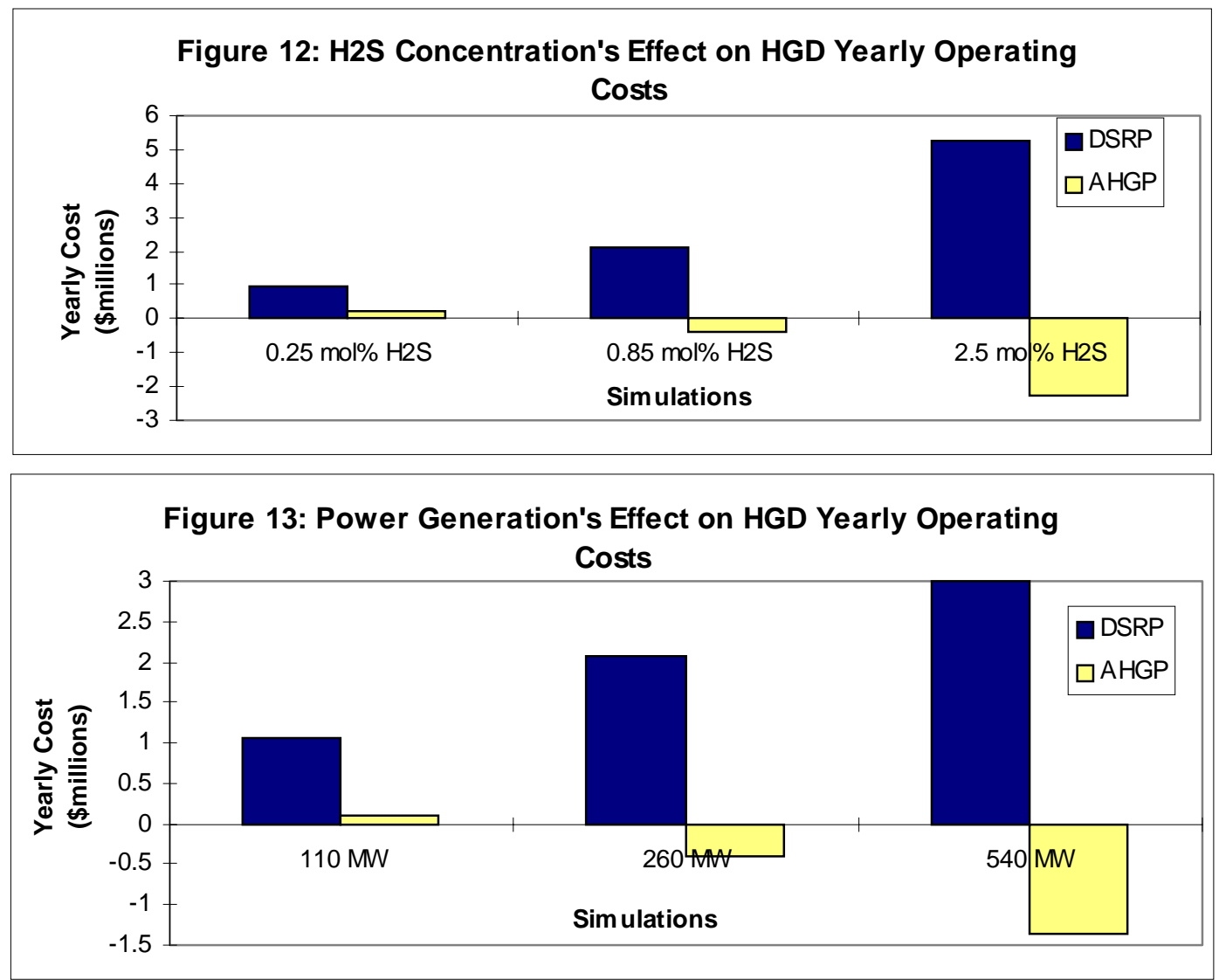

In assessing the yearly cost of maintaining HGD, benefits of the process should also be accounted for. Two sources of credit were observed: the recovery of sulfur and the production of steam. Sulfur credits where consistently larger than steam credits within the same simulation. The sulfur credits remained virtually unchanged between corresponding DSRP and AHGP simulations. Figure 12 and 13 show that for several AHGP conditions the credits are larger than the expenditures. This results in negative yearly operating costs. When larger amounts of sulfur are removed, the yearly expenditures combined with the sulfur and steam credits result in negative yearly costs for the AHGP. In such cases it is more profitable to use the AHGP, then to leave the coal gas stream untreated (if Federal Regulations allowed). The profit that results from the sale of recovered sulfur (Appendix M) allows the AHGP to be more profitable than generating power without desulfurization. 


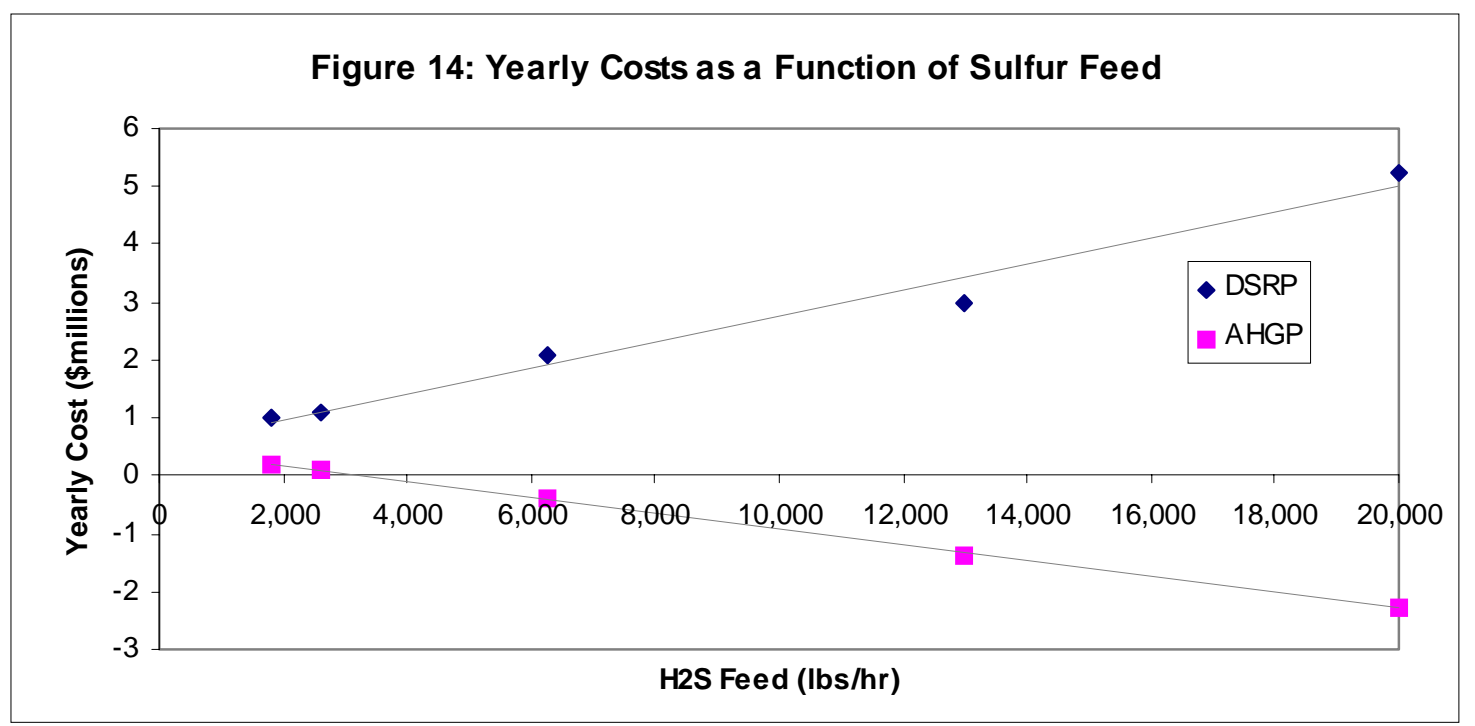

The yearly costs have a linear dependence on the amount of sulfur being processed. This can be seen by comparing all simulations (DSRP, DSRP-b, DSRP-c, DSRP-100, DSRP-500, AHGP, AHGP-b, AHGP-c, AHGP-100, AHGP-500). Figure 14 shows that regardless of how the sulfur feed is varied (changing concentration vs. changing power generation), the yearly costs scale directly with sulfur removed.

\section{2.a. Electrical}

The pumps and compressors have been assumed to account for the majority of the electrical requirements for the HGD processes. The additional power requirements for lighting and instrumentation have been assumed to be $20 \%$ of the compressor and pump requirements for the base case of each HGD. It is assumed that the additional power requirements will not vary significantly with plant size.

The DSRP power requirement is significantly higher than that of the AHGP. The PRESAIR air compressor is the reason for the high DSRP power requirement. The air compressor supplies air to the regenerator for the oxidation of sulfurized sorbent. It is interesting to note that the cost of supplying oxygen by compressing air is more than the cost of separating oxygen and then compressing the pure oxygen. The phenomenon is not unprecedented; it has 
been observed that as the pressure of injection is raised the cost of compressing air increases faster than the cost of separating oxygen and pressuring only oxygen (Hvizdos).

The compressed nitrogen feed to the DSRP - based process regenerator that is included in the air stream will increase the total volumetric flow to the turbine. This would indicate that there should be a power credit associated with the nitrogen's introduction, offsetting some of the compression costs. However, nitrogen will also increase the heat capacity of the stream, lowering the combustion temperature, thus lowering the power production. These competing effects have been assumed to cancel each other out. The design work assumes there is no change in power production attributed to the introduction of nitrogen.

\section{2.b. Cooling Water}

The steam generation/cooling loop is closed; maintaining water purity is not difficult for a self-contained loop. Furthermore, makeup water requirements will be negligible, for the detail level of this report. The is no debit calculated for the HGD steam system water because of the above mentioned reasons.

The steam condensate is assumed to be cooled to $90^{\circ} \mathrm{C}$ by cooling tower water. Tower water is exposed to the atmosphere, which means maintaining water purity will be an issue. There will also be makeup water requirements. Therefore a yearly debit has been calculated for the use of tower water. The tower water flow rates have been calculated in the Complete Steam Generation Scheme simulations (Appendix F). The tower water cools the steam stream that is considered "utilized." Utilized steam is a stream that was steam $\left(441^{\circ} \mathrm{C}, 950 \mathrm{psia}\right)$ but has been reduced to $30 \mathrm{psia}$ and the corresponding bubble point temperature. Tower water cools the utilized steam stream to $90^{\circ} \mathrm{C}$, before its reuse. The cost of the tower water is $\$ 2.6 \times 10^{-5} / \mathrm{lb}$ (Peters). The cost of the tower water is insignificant compared to the other yearly capital expenditures.

The cost of the tower is not an issue as there will already be a tower on site. HGD water sent to it will represent only a minor increase in load. 


\section{2.c. Oxygen}

The cost of supplying oxygen has been assessed as a yearly expenditure with no capital cost. Dr. George Roberts indicated that its reasonable to expect oxygen to cost $\$ 20 /$ ton. The value is reasonable when compared with a dated guideline (Chilton, 1960) stating 99.5\% pure oxygen at $450 \mathrm{psig}$ would sell at $\$ 8$ to $\$ 15 /$ ton. There are no capital costs associated with the supplied oxygen assuming the oxygen will be bought from a gas supplier, in which only a usage charge is assigned. The price has been assumed to be set at $\$ 20 /$ ton, the price will actually be dependent on usage. The unit cost of oxygen decreases as quantity purchased increases.

There are oxygen costs only for the AHGP, since air is used to oxidize the sorbent in the DSRP.

\section{2.d. Additional Employees}

The number of additional employees required to operate the HGD processes have been assumed constant with process size. The additional employees required will depend more upon the complexity of the process than its size. The hiring of two additional engineers and two maintenance personal have been assigned to the DSRP. The AHGP has the hiring of three engineers accounted for. An additional engineer is hired since the AHGP is a more complex process to control because $\mathrm{SO}_{2}$ production and consumption must be balanced. Furthermore, the purity of the $\mathrm{SO}_{2}$ loop must be maintained. Two maintenance personnel are also accounted for in AHGP costs. The unit cost for an engineer is assumed to be $\$ 100,000 /$ year, and maintenance personnel are assumed to cost $\$ 70,000 /$ year. These numbers include the base salary and benefits.

\section{2.e. Consumed Coal Gas}

Coal gas $\left(\mathrm{H}_{2}\right.$ and $\left.\mathrm{CO}\right)$ is consumed in both HGD processes. The consumption reduces the amount power that can be produced. The cost of consumed coal gas is calculated from the $\mathrm{CO}$ and $\mathrm{H}_{2}$ lost during HGD, and calculating the value of the energy that the $\mathrm{CO}$ and $\mathrm{H}_{2}$ could have produced. Calculation of power generation is described in Appendix J.

The DSRP consumes substantially more coal gas then the AHGP; this is the major factor in the lower yearly operating cost of the AHGP. 


\section{2.f. Additional Yearly Expenditures}

Sorbent and catalyst attrition have not been accounted for in this report. The rate at which sorbent and catalyst need to be replaced times their unit cost will represent another yearly expenditure. Assuming the attrition costs for both processes are identical a comparison of the process economics will be unaffected by the absence of attrition costs in this report.

Maintenance charges have not be fully accounted for in this report. While the cost of additional employees to maintain equipment has been included, the cost of the replacement parts and equipment have not. Yearly maintenance costs should increase with years of service as well as with the size of the HGD process.

\section{Economic Summary}

The AHGP has a higher initial startup costs, indicated by its larger capital requirements. However, the AHGP has lower yearly expenditures then the DSRP. The operating cost difference is large enough to offset the initial startup cost difference within a few years.

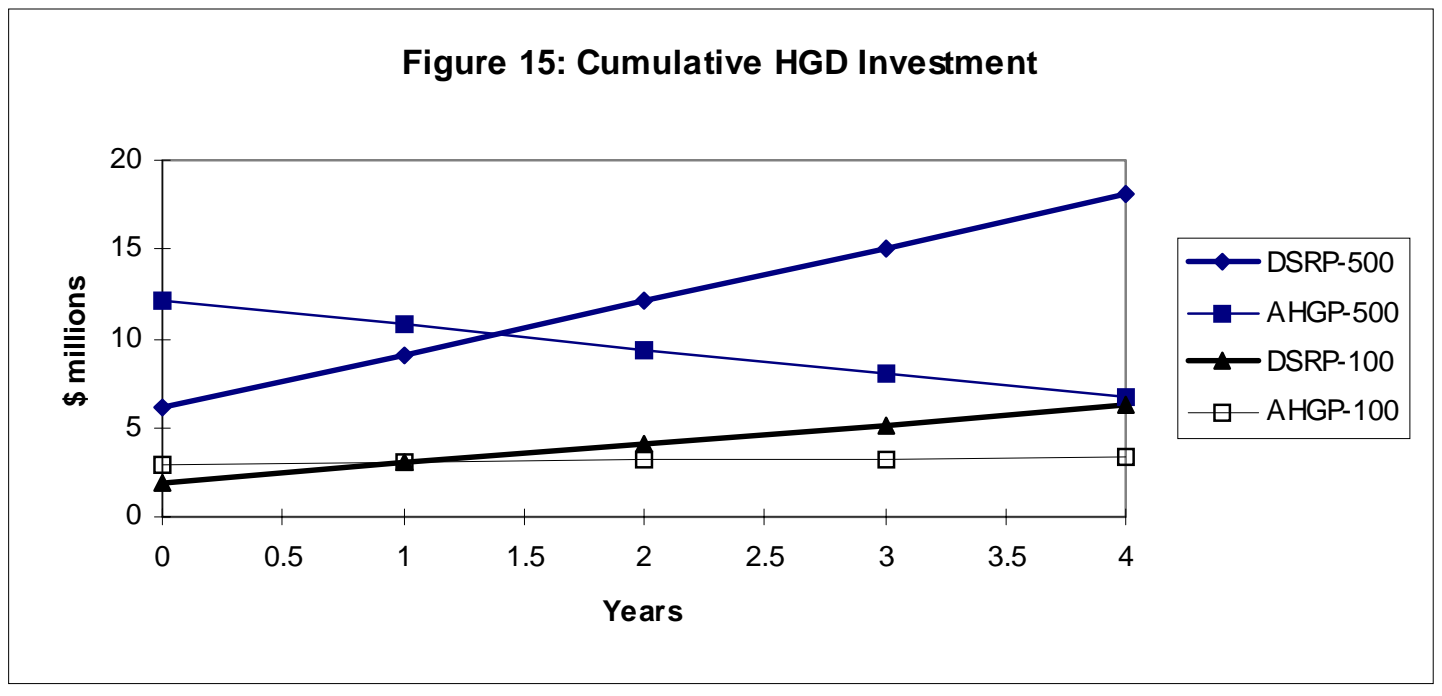

Figure 15 shows that despite an higher initial investment, within two years the AHGP can financially outperform the DSRP. 


\section{SUMMARY}

Mass and energy balances were calculated for the Direct Sulfur Recovery Process based Hot Gas Desulfurization and the Advanced Hot Gas Process. Establishing the balances has helped determine the equipment requirements for both processes. The specifications for the major pieces of equipment have been described in this report.

Simulating the HGD processes revealed the complexity of both processes. The AHGP appears to be the more difficult of the two processes to operate. More employees may be needed to operate the AHGP process than the DSRP -based process.

Capital costs for the AHGP are higher than those for the DSRP. However, yearly operating costs for the AHGP are considerably less than those of the DSRP. After two years of operation the total cost of implementing an AHGP will be less then the cost of a DSRP -based process. It will be more difficult to operate an AHGP but the substantial savings the process delivers makes it the more desirable process to implement. 


\section{REFERENCES}

ASPEN PLUS, Reference Manual - Volume 2 Physical Property Methods and Models, Release 9, Aspen Technology, INC, 1994

Barnett, E. B., Wilson, C. L., Inorganic Chemistry - A Text-book For Advanced Students, 2nd Edition, John Wiley \& Sons Inc., New York, 1957

Bird, R.B., Stewart, W.E., Lightfoot, E.N., Transport Phenomena, John Wiley \& Sons, New York, 1960

Bloch, H. P., A Practical Guide to Compressor Technology, McGraw-Hill, New York 1996

Braker, W., Mossman, A. L., Matheson Gas Data Book, 5th Edition, Matheson Gas Products, Milwaukee, 1971

Brown, R. N., Compressors - Selection \& Sizing, Gulf Publishing Company, Houston 1986

Campbell, W. M., and Henningsen, G. B., "Hot Gas Desulfurization Using Transport Reactors" Proceedings of the Twelfth Annual International Pittsburgh Coal Conference,

Pittsburgh, 1995

Caruanan, C. M., "Processes Aim to Improve Sulfur Recovery From Gases," Chemical Engineering Progress, February 1996, pp. 11-17

Chen, D. H., Kinetically Modified Equilibrium Calculation and Thermodynamic Analysis for the DSRP Hot Gas Sulfur Recovery Process, Final Report to Research Triangle Institute, March 10, 1994 report 1994

Chilton, C. H., Cost Engineering In the Process Industries, McGraw-Hill Company, New York, 1960, pg. 302-303

Cootner, P. H., Lof, G. O., Water Demand for Steam Electric Generation, John Hopkins Press, Baltimore, 1965

Cotton, F. S., Wilkinson, G., Advanced Inorganic Chemistry - A Comprehensive Text, 2nd Edition, Interscience Publishers, New York 1966

Cusumano, J. A., Dalla Betta, and R. A., Levy R. B., Catalysis in Coal Conversion, Academic Press, Inc. New York 1978

Dimoplon, W., "What Process Engineers Need to Know About Compressors," Hydrocarbon Processing May 1978, pp. 221-227 
EPRI CS-4035, “Continuous Testing of the Resox Process,” Project 1257-2, Final Report, May 1985

Gangwal, S. K., Hot-Gas Desulphurisation Sorbent Development for IGCC Systems, "Desulphurisation 2 Technologies and Strategies for Reducing Sulphur Emissions" Institution of Chemical Engineers, New York 1991

Hvizdos, L. J., Howard, J. V., Roberts, G. W., "Enhanced Oil Recovery Through Oxygen Enriched In-Situ Combustion: Test Results From the Forest Hill Field in Texas" Journal of Petroleum Technology June 1983, pp. 1061-1070

Jaffee, R. I., "Advances in Materials for Fossil Power Plants," Advances in Material Technology for Fossil Power Plant - Proceedings of an International Conference on Advances in Material Technology for Fossil Power Plants, ASM International, Chicago, 1987

Kern, D. Q., Process Heat Transfer, McGraw-Hill Book Company, New York, 1950

Noyes, R. Cogeneration of Steam and Electric Power, Noyes Data Corporation Park Ridge, Park Ridge, NJ, 1978

Perry, R.H., Green, D.W., Maloney, J.O., Perry's Chemical Engineers' Handbook, 6th Edition, McGraw Hill Inc., New York, 1984

Peters, M. S., Timmerhaus, K. D., Plant Design and Economics for Chemical Engineers, 4th Edition, McGraw Hill Inc. New York, 1991

Portzer, J. W., Research Triangle Institute internal memo, November 26, 1996

Ulrich, G. D., A Guide to Chemical Engineering Process Design And Economics, John Wiley \& Sons, Inc. New York 1984

U.S. Geological Survey, Minerals Information, http://minerals.er.usgs.gov/minerals/pubs/commodity/sulfur/stat/

Welty, J.R., Wicks, C.E., Wilson, R.E., Fundamentals of Momentum, Heat, and Mass Transfer, 3rd Edition, John Wiley \& Sons, New York, 1984 


\section{Appendix A \\ Calculation of the $\mathrm{SO}_{2}$ Circulation Rate for AHGP}

$\mathrm{SO}_{2}$ circulation rates are set to create the desired flow conditions in the regenerating reactor. First the sorbent flow rate through the regenerator must be determined. $\mathrm{Al}_{2} \mathrm{O}_{3}$ must pass through the reactor in large quantities to keep the adiabatic temperature raise small. The sorbent flow is used to determine the reactor's cross sectional area. The $\mathrm{SO}_{2}$ circulation rate necessary to provide a $2.5 \mathrm{~cm} / \mathrm{s}$ upwards velocity is then calculated. Calculation results follow:

\section{SO2 Regenerator Sizing - Commercial Embodiment}
AGHP
(SO2 Regen)
Case $\mathrm{E}-2$
AHGP-b
(SO2 Regen)
Case E-2

AHGP-C
Givens:

Sorbent circulation rate, $\mathrm{lb} / \mathrm{hr}$

Sorbent bulk density, lb/ft3

Req'd rxtr residence time, $\mathrm{hr}$

Regen Gas $v_{\text {super }}, \mathrm{cm} / \mathrm{sec}$

Desired H/D

\section{Adjusted values:}

Assumed Bed Depth, $\mathrm{ft}$

$\mathrm{SO} 2$ needed $\mathrm{ft} 3 / \mathrm{hr}$

Calculated values:

Hold-up volume, $\mathrm{ft} 3$

Diameter, $\mathrm{ft}$

$\mathrm{X}$-section area, $\mathrm{ft} 2$

Calculated H/D

RG Vol. flow rate, acf/sec

$\mathrm{RG}$ flow rate, $\mathrm{lb} / \mathrm{hr}$

Ratio of RG flow/sorbent, lb/lb

Calculated Bed Depth, $\mathrm{ft}$
496000

62.4

1

2.5

2

10

238,462

79,813

2660

18

266

0.54

21.8

86366

0.52

Operating conditions/Gas Density Calc'ns:

Pressure, psig

Pressure, psia

MW of gas

Bed Temp., C

Bed Temp., R

$\mathrm{R}$, gas constant,

Gas density, lb/ft3
275

289.7

64

600

1571.67

10.73

1.1
275

289.7

64

600

1571.67

10.73

1.1
48000

62.4

1

2.5

2

10

23,077

769

9.9

77

1.01

6.3

24972

0.52

275

289.7

64

600

1571.67

10.73

1.1 


\section{Appendix B \\ Heat Transfer Coefficients}

The following approximate overall heat transfer coefficients were found in the literature. The values were in used estimating the heat exchangers' overall heat transfer coefficients.

\begin{tabular}{lll} 
Hot Fluid & $\begin{array}{l}\text { Coolers } \\
\text { Cold Fluid }\end{array}$ & Overall $\mathrm{U}_{\mathrm{D}}, \mathrm{BTU} / \mathrm{hr} \mathrm{ft}^{2} \mathrm{~F}^{\circ}$ \\
\hline Water & Water & $250-500$ \\
Gases & Water & $2-50$ \\
& Heaters & \\
& Cold Fluid & Overall $\mathrm{U}_{\mathrm{D}}, \mathrm{BTU} / \mathrm{hr} \mathrm{ft}^{2} \mathrm{~F}^{\circ}$ \\
Hot Fluid & Water & $200-700$ \\
Steam & Gases & $5-50$ \\
Steam & &
\end{tabular}

Values above found in Kern (1950).

\begin{tabular}{lc} 
Fluid combination & $\mathrm{U}, \mathrm{BTU} / \mathrm{hr} \mathrm{ft}^{2}{ }^{\circ} \mathrm{F}$ \\
\hline Water to compressed air & $10-30-275$ \\
Water to water & $100-600$ \\
Steam to aqueous solutions & $5-50$ \\
Steam to gases &
\end{tabular}

Values above found in Welty, Wicks, and Wilson (1984). 


\section{Appendix C \\ Determination of Catalyst Velocity in DSRP Reactor}

In order to determine whether the catalyst in the DSRP Reactor (a fast fluid-bed reactor) will be transported to the top of the reactor by the gas feed, the following calculation was performed. A terminal velocity calculation was performed on a catalyst particle. This calculation will approximate the catalyst's velocity relative to the gas phase. The gas velocity through the DSRP will be $3 \mathrm{ft} / \mathrm{s}(0.9 \mathrm{~m} / \mathrm{s})$. The catalyst's relative velocity needs to be less than the gas velocity in order for the catalyst to be elevated.

Terminal velocity is determined from a force balance on the particle.

$$
\begin{gathered}
\mathrm{m} \frac{\mathrm{dv}}{\mathrm{dt}}=\mathrm{F}_{\mathrm{g}}-\mathrm{F}_{\mathrm{d}}-\mathrm{F}_{\mathrm{b}} \\
\mathrm{m} \frac{\mathrm{dv}}{\mathrm{dt}}=\mathrm{mg}-\frac{\mathrm{C}_{\mathrm{D}}{ }^{2} \rho\left(\pi \mathrm{D}_{\mathrm{p}}^{2} / 4\right)}{2}-\frac{\mathrm{m} \rho \mathrm{g}}{\rho_{\mathrm{p}}}
\end{gathered}
$$

At steady state the left side equals zero and the equations simplify to give the steady state (terminal) velocity:

$$
\mathrm{v}_{\mathrm{ss}}=\sqrt{\frac{4}{3}\left(\frac{\mathrm{D}_{\mathrm{p}} \mathrm{g}}{\mathrm{C}_{\mathrm{D} \rho} \rho}\right)\left(\rho_{\mathrm{p}}-\rho\right)}
$$

The catalyst size is 160 micron.

$$
\mathrm{D}_{\mathrm{p}}=1.6 \times 10^{-4} \mathrm{~m} \quad \rho_{\mathrm{p}}=1.2 \mathrm{~g} / \mathrm{cm}^{3} \quad \mathrm{~g}=9.8 \mathrm{~m} / \mathrm{s}^{2}
$$

Bulk samples of the catalyst have a density $\left(\rho_{\text {bulk }}\right)$ of $0.9 \mathrm{~g} / \mathrm{cm}^{3}$. The bulk catalyst is assumed to have a packing fraction of 0.74 , the highest packing fraction possible for spheres. Assuming the packing fraction enables calculation of the individual catalyst density $\left(\rho_{p}\right)$.

$$
\rho_{\mathrm{p}}=\rho_{\text {bulk }} /(\text { packing fraction }) \quad \rho_{\mathrm{p}}=1.2 \mathrm{~g} / \mathrm{cm}^{3}=\left(0.9 \mathrm{~g} / \mathrm{cm}^{3}\right) /(0.74)
$$

The gas density is taken as a weighted average of the feeds ROG-COOL and SLIPSTRM.

$$
\rho=0.50 \mathrm{lb} / \mathrm{ft}^{3} \times(1,000 \mathrm{gr}) /(2.205 \mathrm{lb}) \times\left(1 \mathrm{ft}^{3}\right) /(30.48 \mathrm{~cm})^{3}=0.008 \mathrm{~g} / \mathrm{cm}^{3}=8 \mathrm{~kg} / \mathrm{m}^{3}
$$


Inserting the values gives:

$$
\mathrm{v}_{\mathrm{Ss}}=\sqrt{\frac{0.3136 \frac{\mathrm{m}^{2}}{\mathrm{~s}^{2}}}{\mathrm{C}_{\mathrm{D}}}}
$$

The drag coefficient $\mathrm{C}_{\mathrm{D}}$ is correlated with the Reynolds number $\left(\mathrm{N}_{\mathrm{Re}}\right)$ of the gas phase. After determining the Reynolds number $C_{D}$ can be determined from charts in Bird (1960).

$$
\mathrm{N}_{\mathrm{Re}}=\mathrm{D}_{\mathrm{p}} \mathrm{V}_{\mathrm{ss}} \rho / \mu
$$

The steady state velocity is determined iteratively. That leaves $\mu$, viscosity of the gas, the only other unknown.

For viscosity calculations, the gas will been assumed to have the properties of nitrogen $\left(\mathrm{N}_{2}\right.$ represents over $50 \mathrm{wt} \%$ of reactor gas).

Reactor conditions $\mathrm{T}=600^{\circ} \mathrm{C}$ and $\mathrm{P}=275$ psia.

The Reichenberg correlation was used for the determination of the high pressure viscosity (Perry's 3-279). The correlation typically has errors of less than 10 percent.

\section{Equations}

$$
\begin{aligned}
& \left(\mu-\mu^{0}\right) /\left(\mu^{\mathrm{o}} P\right)=\mathrm{AP}_{\mathrm{r}}^{1.5} /\left[\mathrm{B} \mathrm{P}_{\mathrm{r}}+\left(1+\mathrm{C} \mathrm{P}_{\mathrm{r}}^{\mathrm{D}}\right)^{-1}\right] \\
& \mathrm{A}=1.9824 \times 10^{-3} \mathrm{~T}_{\mathrm{r}}^{-1} \exp \left(5.2683 \mathrm{~T}_{\mathrm{r}}^{-0.5767}\right) \\
& \mathrm{B}=\mathrm{A}\left(1.6552 \mathrm{~T}_{\mathrm{r}}-1.2760\right) \\
& \mathrm{C}=0.1319 \mathrm{~T}_{\mathrm{r}}^{-1} \exp \left(3.7035 \mathrm{~T}_{\mathrm{r}}^{-79.8678}\right) \\
& \mathrm{D}=2.9496 \mathrm{~T}_{\mathrm{r}}^{-1} \exp \left(2.9190 \mathrm{~T}_{\mathrm{r}}^{-16.6169}\right) \\
& \mathrm{T}_{\mathrm{r}}=\mathrm{T} / \mathrm{T}_{\mathrm{c}}=873 \mathrm{~K} / 126.2 \mathrm{~K}=6.91 \quad \mathrm{P}_{\mathrm{r}}=\mathrm{P} / \mathrm{P}_{\mathrm{c}}=275 \mathrm{psia} / 492 \mathrm{psia}=0.559 \\
& \mu^{\mathrm{o}}=\mu(1 \mathrm{~atm}, 873 \mathrm{~K})=3.8 \times 10^{8} \text { Poise } \\
& \text { And for nonpolar molecules: } P=1 \\
& \text { Calculated Values } \\
& \mathrm{A}=0.001615 \quad \mathrm{~B}=0.0164 \quad \mathrm{C}=0.01909 \quad \mathrm{D}=0.4269 \\
& \left(\mu-\mu^{0}\right) /\left(\mu^{0}\right)=6.7498 \times 10^{-4} / 0.9945=6.787 \times 10^{-4} \\
& \mu=3.8 \times 10^{-4}+\left(3.8 \times 10^{-4}\right)\left(6.787 \times 10^{-4}\right) \text { Poise }
\end{aligned}
$$




$$
\mu=3.8 \times 10^{-4} \text { Poise }=3.8 \times 10^{-5} \mathrm{~Pa} \mathrm{~s}=3.8 \times 10^{-5} \mathrm{~kg} /(\mathrm{m} \mathrm{s})
$$

The Reynolds number is can now be expressed:

$$
\begin{gathered}
\mathrm{N}_{\mathrm{Re}}=\left(1.6 \times 10^{-4} \mathrm{~m}\right)\left(\mathrm{v}_{\mathrm{ss}}\right)\left(8 \mathrm{~kg} / \mathrm{m}^{3}\right) /\left[3.8 \times 10^{-5} \mathrm{~kg} /(\mathrm{m} \mathrm{s})\right] \\
\mathrm{N}_{\mathrm{Re}}=\left(\mathrm{v}_{\mathrm{ss}}\right) 33.68 \mathrm{~s} / \mathrm{m}
\end{gathered}
$$

And our velocity equation is: $v_{\mathrm{ss}}=\sqrt{\frac{0.3136 \frac{\mathrm{m}^{2}}{\mathrm{~s}^{2}}}{\mathrm{C}_{\mathrm{D}}}}$

First Iteration, take $\mathrm{v}_{\mathrm{ss}}=0.9 \mathrm{~m} / \mathrm{s}$ then $\mathrm{N}_{\mathrm{Re}}=30$ (above equation)

For the above Reynolds number $\mathrm{C}_{\mathrm{D}}=2.4$ (Fig. 6.3-1 in Bird)

Velocity equation gives $\mathrm{v}_{\mathrm{ss}}=0.36 \mathrm{~m} / \mathrm{s}$

The calculations are repeated.

Second iteration:

$$
\begin{aligned}
& \mathrm{v}_{\mathrm{ss}}=0.36 \mathrm{~m} / \mathrm{s} \\
& \mathrm{C}_{\mathrm{D}}=4.2
\end{aligned}
$$$$
\mathrm{N}_{\mathrm{Re}}=12
$$$$
\mathrm{v}_{\mathrm{ss}}=0.27 \mathrm{~m} / \mathrm{s}
$$

Third iteration:

$$
\begin{array}{ll}
\mathrm{v}_{\mathrm{ss}}=0.27 \mathrm{~m} / \mathrm{s} & \mathrm{N}_{\mathrm{Re}}=9.09 \\
\mathrm{C}_{\mathrm{D}}=4.9 & \mathrm{v}_{\mathrm{ss}}=0.252 \mathrm{~m} / \mathrm{s}
\end{array}
$$

Fourth iteration:

$$
\begin{array}{ll}
\quad \mathrm{v}_{\mathrm{ss}} 0.252 \mathrm{~m} / \mathrm{s} & \multicolumn{1}{c}{\mathrm{N}_{\mathrm{Re}}=8.49} \\
\mathrm{C}_{\mathrm{D}}=5.13 & \mathrm{~V}_{\mathrm{ss}}=0.247 \mathrm{~m} / \mathrm{s} \\
& \mathrm{N}_{\mathrm{Re}}=8.33 \\
\mathrm{~V}_{\mathrm{ss}} 0.247 \mathrm{~m} / \mathrm{s} & \mathrm{v}_{\mathrm{ss}}=0.246 \mathrm{~m} / \mathrm{s} \\
\mathrm{C}_{\mathrm{D}}=5.19 &
\end{array}
$$

Fifth iteration:

The velocity of falling catalyst is $0.25 \mathrm{~m} / \mathrm{s}$. Thus in a gas stream flowing up at $0.9 \mathrm{~m} / \mathrm{s}$ the catalyst will rise at $0.65 \mathrm{~m} / \mathrm{s}(2.1 \mathrm{ft} / \mathrm{s})$.

CONCLUSION:The gas stream will be capable of elevating the catalyst.

Sorbent in the risers will be elevated at approximately the same velocity ( $20 \mathrm{ft} / \mathrm{s})$ as the gas lifting it. 


\section{Appendix D \\ Calculation of DSRP Catalyst Cycling Rate}

The rate at with catalyst is fed to the DSRP was determined by the heat removal requirements of the DSRP reactor. Heat is removed from the reactor by cooling the catalyst effluent and reintroducing that catalyst. Exiting catalyst temperature is set at $600^{\circ} \mathrm{C}$ and the catalyst is cooled to $500^{\circ} \mathrm{C}$.

\section{Catalyst Properties}

The DSRP reactor catalyst is a porous aluminum oxide catalyst modeled as $\mathrm{Al}_{2} \mathrm{O}_{3}$. Catalyst density at ambient conditions is $56.18 \mathrm{lb} / \mathrm{ft}^{3}$. This density includes the void space filled by air. ASPEN was utilized to determine the void space in the settled catalyst, assuming nitrogen fills the voids in the solid catalyst. At ambient conditions $1 \mathrm{lb}$ of $\mathrm{Al}_{2} \mathrm{O}_{3}$ and $0.00095 \mathrm{lb}$ of $\mathrm{N}_{2}$ have a combined density of $55.6 \mathrm{lb} / \mathrm{ft}^{3}$.

The similar densities allow us to assume that there is roughly $0.00095 \mathrm{lb}$ of nitrogen present for every $1 \mathrm{lb}$ of solid $\mathrm{Al}_{2} \mathrm{O}_{3}$ (at ambient conditions). That quantity of nitrogen occupies $0.0132 \mathrm{ft}^{3}$ (at ambient conditions). This represents the catalyst void volume and is expected to remain constant.

$\mathrm{V}_{\text {void }}=0.0132 \mathrm{ft}^{3} / 1 \mathrm{lb} \mathrm{Al}_{2} \mathrm{O}_{3}$

The density of the gas in the reactor was taken as the average of nitrogen's density at $600^{\circ} \mathrm{C}(275$ psia) and $500^{\circ} \mathrm{C}(275 \mathrm{psia})$.

$$
\rho_{\text {gas }}=0.483 \mathrm{lb} / \mathrm{ft}^{3}
$$

Therefore the mass of gas (in the settled catalyst) per pound $\mathrm{Al}_{2} \mathrm{O}_{3}$ can be calculated.

$$
\mathrm{M}_{\text {gas }}=0.483 \mathrm{lb} / \mathrm{ft}^{3} \times 0.0132 \mathrm{ft}^{3}=0.0064 \mathrm{lbs}
$$

The heat transfer requirements for cooling $\mathrm{Al}_{2} \mathrm{O}_{3}$ were than simulated (including cooling nitrogen contained in the catalyst voids).

$$
\mathrm{Q}\left(600^{\circ} \mathrm{C}->500^{\circ} \mathrm{C}\right)=-51.239 \mathrm{BTU} / \mathrm{lb} \mathrm{Al}_{2} \mathrm{O}_{3}
$$


Calculation of necessary catalyst circulation rate:

$$
\text { (circulation rate }\{\mathrm{lb} / \mathrm{hr}\})=\left(\mathrm{Q}_{\mathrm{DSRP}}\right) /\left(-51.239 \mathrm{BTU} / \mathrm{lb} \mathrm{Al} \mathrm{O}_{3}\right)
$$

DSRP (circulation rate $\{\mathrm{lb} / \mathrm{hr}\})=(-15,340,000 \mathrm{BTU} / \mathrm{hr}) /\left(-51.239 \mathrm{BTU} / \mathrm{lb} \mathrm{Al}_{2} \mathrm{O}_{3}\right)$ $=300,000 \mathrm{lb} \mathrm{Al}_{2} \mathrm{O}_{3} / \mathrm{hr}$

DSRP-b (circulation rate $\{\mathrm{lb} / \mathrm{hr}\})=(-51,320,000 \mathrm{BTU} / \mathrm{hr}) /\left(-51.239 \mathrm{BTU} / \mathrm{lb} \mathrm{Al}_{2} \mathrm{O}_{3}\right)$ $=1,000,000 \mathrm{lb} \mathrm{Al}_{2} \mathrm{O}_{3} / \mathrm{hr}$

DSRP-c (circulation rate $\{\mathrm{lb} / \mathrm{hr}\})=(-4,029,000 \mathrm{BTU} / \mathrm{hr}) /\left(-51.239 \mathrm{BTU} / \mathrm{lb} \mathrm{Al}_{2} \mathrm{O}_{3}\right)$ $=79,000 \mathrm{lb} \mathrm{Al}_{2} \mathrm{O}_{3} / \mathrm{hr}$

DSRP-100 (circulation rate $\{\mathrm{lb} / \mathrm{hr}\})=(-6,459,000 \mathrm{BTU} / \mathrm{hr}) /\left(-51.239 \mathrm{BTU} / \mathrm{lb} \mathrm{Al}_{2} \mathrm{O}_{3}\right)$ $=130,000 \mathrm{lb} \mathrm{Al}_{2} \mathrm{O}_{3} / \mathrm{hr}$

DSRP-500 (circulation rate $\{\mathrm{lb} / \mathrm{hr}\})=(-31,370,000 \mathrm{BTU} / \mathrm{hr}) /\left(-51.239 \mathrm{BTU} / \mathrm{lb} \mathrm{Al}_{2} \mathrm{O}_{3}\right)$ $=610,000 \mathrm{Ib} \mathrm{Al}_{2} \mathrm{O}_{3} / \mathrm{hr}$ 


\section{Appendix E \\ Process Flowsheets and Stream Summaries}

Direct Sulfur Recovery Process Simulations

$\begin{array}{lll}\text { DSRP (base case) } & 0.85 \text { mole } \% \mathrm{H}_{2} \mathrm{~S} & 260 \mathrm{MW} \text { generated } \\ \text { DSRP-b } & 2.50 \text { mole } \% \mathrm{H}_{2} \mathrm{~S} & 260 \mathrm{MW} \text { generated } \\ \text { DSRP-c } & 0.25 \text { mole } \% \mathrm{H}_{2} \mathrm{~S} & 260 \mathrm{MW} \text { generated } \\ \text { DSRP-100* } & 0.85 \text { mole } \% \mathrm{H}_{2} \mathrm{~S} & 110 \mathrm{MW} \text { generated } \\ \text { DSRP-500 } & 0.85 \text { mole } \% \mathrm{H}_{2} \mathrm{~S} & 540 \mathrm{MW} \text { generated }\end{array}$

Advanced Hot Gas Process Simulations

$\begin{array}{lll}\text { AHGP (base case) } & 0.85 \text { mole } \% \mathrm{H}_{2} \mathrm{~S} & 260 \mathrm{MW} \text { generated } \\ \text { AHGP-b } & 2.50 \text { mole } \% \mathrm{H}_{2} \mathrm{~S} & 260 \mathrm{MW} \text { generated } \\ \text { AHGP-c } & 0.25 \text { mole } \% \mathrm{H}_{2} \mathrm{~S} & 260 \mathrm{MW} \text { generated } \\ \text { AHGP-100* } & 0.85 \text { mole } \% \mathrm{H}_{2} \mathrm{~S} & 110 \mathrm{MW} \text { generated } \\ \text { AHGP-500* } & 0.85 \text { mole } \% \mathrm{H}_{2} \mathrm{~S} & 540 \mathrm{MW} \text { generated }\end{array}$

*DSRP-100, AHGP-100, and AHGP-500 were not simulated. The flowrates and heat duties will scale directly from the base cases (DSRP and AHGP). DSRP-100 and AHGP-100 values equal DSRP and AHGP values scaled by 0.4211. AHGP-500 values equal AHGP values scaled by 2.1055 . 


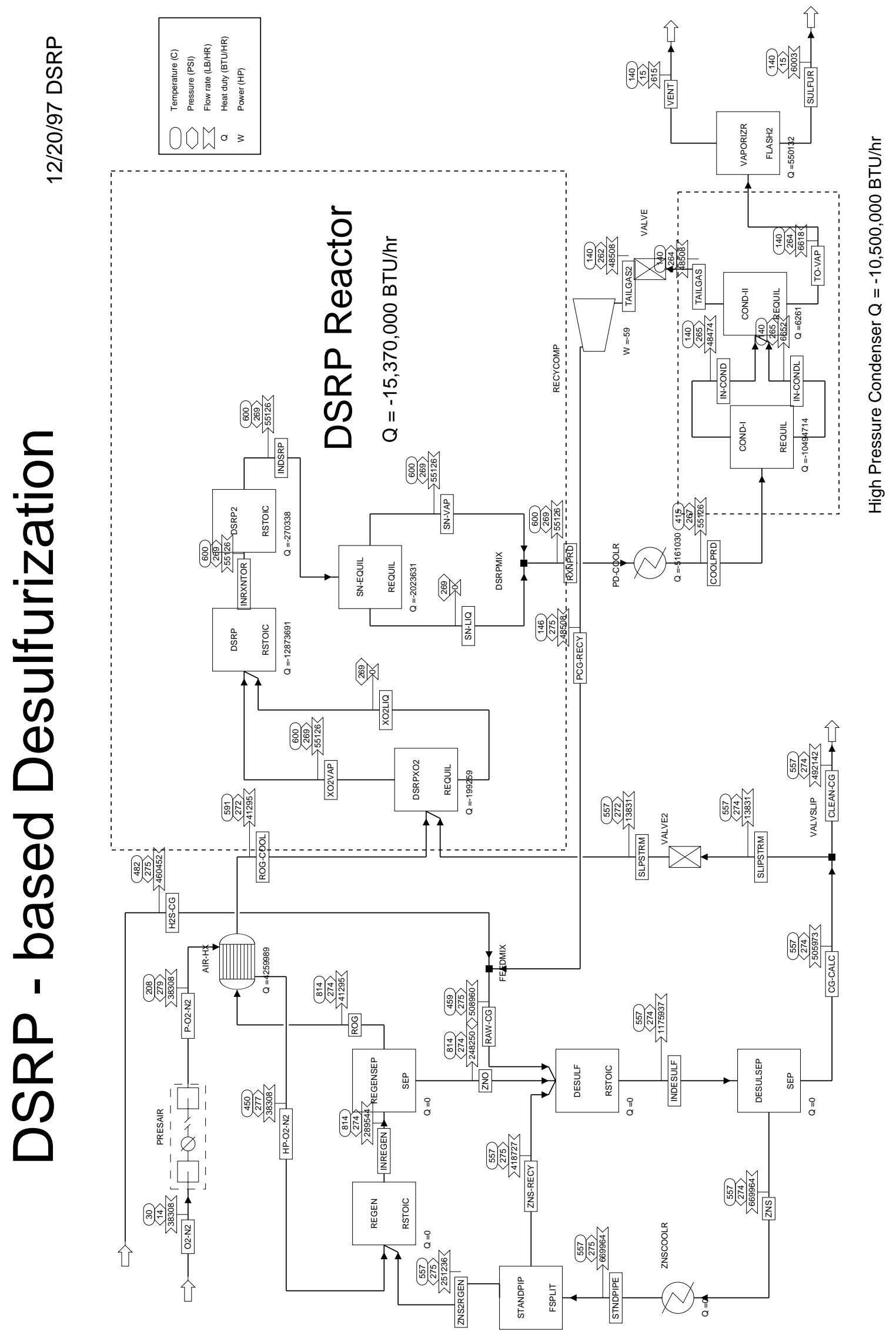


DSRP 12/20/97 pg1

\begin{tabular}{|c|c|c|c|c|c|c|c|c|c|c|c|c|c|c|c|}
\hline Temperature & {$[\mathrm{C}]$} & \begin{tabular}{|r|}
557.2 \\
\end{tabular} & \begin{tabular}{|r|}
557.2 \\
\end{tabular} & 415 & \begin{tabular}{|r|}
482.2 \\
\end{tabular} & 450 & 140 & 140 & \begin{tabular}{|r|}
557.2 \\
\end{tabular} & 600 & \begin{tabular}{|r|}
814.4 \\
\end{tabular} & 600 & 30 & Temperature & {$[\mathrm{C}]$} \\
\hline Pressure & [PSI] & 274.4 & 274.4 & 266.6 & 275 & 276.9 & 264.6 & 264.6 & 274.4 & 268.6 & 273.6 & 268.6 & 13.7 & Pressure & [PSI] \\
\hline Mass VFrac & & 1 & 1 & 1 & 1 & 1 & 1 & 0 & $\begin{array}{l}0.43 \\
\end{array}$ & 1 & 0.143 & 1 & & Mass VFrac & \\
\hline Mass SFrac & & 0 & 0 & 0 & 0 & 0 & 0 & 0 & 0.57 & 0 & 0.857 & & & \begin{tabular}{|l|} 
Mass SFrac \\
\end{tabular} & \\
\hline${ }^{* * *}$ ALL PHAS & $E S^{* \star *}$ & & & & & & & & & & & & & ${ }^{* * *}$ ALL PHAS & $E S^{* * *}$ \\
\hline \begin{tabular}{|l|} 
Mass Flow \\
\end{tabular} & {$[\mathrm{LB} / \mathrm{HR}]$} & 505972.781 & 492141.531 & 55125.902 & 460451.688 & 38308.016 & $\begin{array}{l}48474.25 \\
\end{array}$ & 6651.654 & $1.18 \mathrm{E}+06$ & 55125.902 & 289544.469 & 55126.063 & 38308.016 & Mass Flow & {$[\mathrm{LB} / \mathrm{HR}]$} \\
\hline Volume Flow & [CUFT/HR] & $1.37 \mathrm{E}+06$ & $1.33 \mathrm{E}+06$ & 87129.523 & $1.15 \mathrm{E}+06$ & 67432.328 & 49166.316 & 48.953 & $1.37 \mathrm{E}+06$ & 112094.914 & \begin{tabular}{rl|}
96496.891 \\
\end{tabular} & 111308.695 & 567372.75 & Volume Flow & [CUFT/HR] \\
\hline Enthalpy & [BTU/HR] & $-1.15 \mathrm{E}+09$ & $-1.11 E+09$ & $-6.57 \mathrm{E}+07$ & $-1.09 E+09$ & $7.31 \mathrm{E}+06$ & $-7.15 \mathrm{E}+07$ & $-4.68 \mathrm{E}+06$ & $-4.84 \mathrm{E}+09$ & $-5.85 \mathrm{E}+07$ & $-1.38 \mathrm{E}+09$ & $-5.82 \mathrm{E}+07$ & 79241.141 & Enthalpy & {$[\mathrm{BTU} / \mathrm{HR}]$} \\
\hline \begin{tabular}{|l|} 
Density \\
\end{tabular} & [LB/CUFT] & 0.37 & $\begin{array}{l}0.37 \\
\end{array}$ & 0.633 & $\begin{array}{l}0.399 \\
\end{array}$ & $\begin{array}{l}0.568 \\
\end{array}$ & 0.986 & 135.877 & 0.857 & 0.492 & 3.001 & $\begin{array}{l}0.495 \\
\end{array}$ & $\begin{array}{l}0.068 \\
\end{array}$ & \begin{tabular}{|l|} 
Density \\
\end{tabular} & [LB/CUFT] \\
\hline \begin{tabular}{|l} 
Mass Flow \\
\end{tabular} & {$[\mathrm{LB} / \mathrm{HR}]$} & & & & & & & & & & & & & \begin{tabular}{|l|} 
Mass Flow \\
\end{tabular} & {$[\mathrm{LB} / \mathrm{HR}]$} \\
\hline \begin{tabular}{|l}
$\mathrm{O} 2 \mathrm{~S}$ \\
\end{tabular} & & 63.71 & 61.968 & 63.879 & & & 63.7 & 0.18 & 63.71 & 63.879 & 11909.276 & $\begin{array}{l}1787.733 \\
\end{array}$ & & O2S & \\
\hline $\mathrm{H} 2 \mathrm{~S}$ & & 6.82 & 6.634 & 72.073 & 6270.481 & & 71.958 & 0.116 & 6.82 & $\begin{array}{l}72.072 \\
\end{array}$ & & $\begin{array}{l}72.072 \\
\end{array}$ & & $\mathrm{H} 2 \mathrm{~S}$ & \\
\hline $\mathrm{H} 2 \mathrm{O}$ & & $\begin{array}{l}78082.43 \\
\end{array}$ & 75947.969 & 4963.325 & 70525.25 & & 4175.116 & 788.209 & 78082.43 & 4963.325 & & 4963.325 & & $\mathrm{H} 2 \mathrm{O}$ & \\
\hline S2 & & \begin{tabular}{|l|}
$<0.001$ \\
\end{tabular} & $<0.001$ & 2631.176 & & & $<0.001$ & 0.212 & $<0.001$ & 5861.615 & & \begin{tabular}{|l|}
3273.283 \\
\end{tabular} & & S2 & \\
\hline 56 & & \begin{tabular}{|r|}
0.39 \\
\end{tabular} & 0.38 & 1891.255 & & & 0.965 & 1890.29 & $\begin{array}{r}0.39 \\
\end{array}$ & 0.011 & & 0.011 & & S6 & \\
\hline 58 & & 2.764 & 2.688 & 1339.271 & & & 2.025 & 3968.209 & 2.764 & 0.076 & & 0.076 & & 58 & \\
\hline $\mathrm{CO}$ & & 218164.266 & 212200.516 & 2.262 & 218162 & & $\begin{array}{r}2.262 \\
\end{array}$ & $\mid<0.001$ & 218164.266 & $\begin{array}{r}2.262 \\
\end{array}$ & & 2.262 & & $\mathrm{CO}$ & \\
\hline $\mathrm{CO} 2$ & & 130332.672 & 126769.898 & 12929.425 & 117407.195 & & 12925.243 & \begin{tabular}{|l|l|}
3.181 \\
\end{tabular} & 130332.672 & 12929.425 & & 10560.996 & & $\mathrm{CO} 2$ & \\
\hline $\mathrm{H} 2$ & & \begin{tabular}{|c|}
11766.221 \\
\end{tabular} & 11444.579 & $\begin{array}{l}0.85 \\
\end{array}$ & 11765.37 & & 0.85 & $5<0.001$ & \begin{tabular}{|c|}
11766.221 \\
\end{tabular} & $\begin{array}{l}0.85 \\
\end{array}$ & & 0.85 & & $\mathrm{H} 2$ & \\
\hline $\mathrm{O} 2$ & & & & & & $\begin{array}{l}8922.588 \\
\end{array}$ & & & & & & & \begin{tabular}{|l|l|}
8922.588 \\
\end{tabular} & $\mathrm{O} 2$ & \\
\hline N2 & & 67553.203 & 65706.57 & 31232.063 & 36321.383 & 29385.428 & 31231.807 & 0.256 & 67553.203 & 31232.063 & 29385.428 & 31232.063 & 29385.428 & N2 & \\
\hline $\cos$ & & 0.323 & $\begin{array}{l}0.314 \\
\end{array}$ & 0.323 & & & $\begin{array}{l}0.323 \\
\end{array}$ & $3<0.001$ & $\begin{array}{l}0.323 \\
\end{array}$ & 0.323 & & 3233.392 & & $\cos$ & \\
\hline $\mathrm{ZNO}$ & & & & & & & & & & & 15129.819 & & & $\mathrm{ZNO}$ & \\
\hline ZNS & & & & & & & & & 144457.359 & & 36055 & & & ZNS & \\
\hline AL2O3 & & & & & & & & & 525506.5 & & 197064.938 & & & AL2O3 & \\
\hline
\end{tabular}


DSRP 12/20/97 pg.2

\begin{tabular}{|c|c|c|c|c|c|c|c|c|c|c|c|c|c|c|c|}
\hline \begin{tabular}{|l|} 
Display ALLS \\
Units: \\
Format: SOLI \\
\end{tabular} & $\begin{array}{l}\text { TREAMS } \\
\text { From } \\
\text { DS To } \\
\text { Phas }\end{array}$ & \begin{tabular}{|l|} 
P-O2-N2 \\
PRESAIR \\
AIR-HX \\
VAPOR \\
\end{tabular} & \begin{tabular}{|l|} 
PCG-RECY \\
RECYCOMP \\
FEEDMIX \\
VAPOR \\
\end{tabular} & \begin{tabular}{|l|} 
RAW-CG \\
FEEDMIX \\
DESULF \\
VAPOR \\
\end{tabular} & \begin{tabular}{|l|} 
ROG \\
REGENSEP \\
AIR-HX \\
VAPOR \\
\end{tabular} & $\begin{array}{l}\text { ROG-COOL } \\
\text { AIR-HX } \\
\text { DSRPXO2 } \\
\text { VAPOR }\end{array}$ & \begin{tabular}{|l|} 
RXNPRD \\
DSRPMIX \\
PD-COOLR \\
VAPOR \\
\end{tabular} & \begin{tabular}{|l|} 
SLIPSTRM \\
VALVSLIP \\
VALVE2 \\
VAPOR
\end{tabular} & \begin{tabular}{|l|} 
SLPSTRM \\
VALVE2 \\
DSRPXO2 \\
VAPOR \\
\end{tabular} & $\begin{array}{l}\text { SN-LIQ } \\
\text { SN-EQUIL } \\
\text { DSRPMIX } \\
\text { MISSING }\end{array}$ & \begin{tabular}{|l|} 
SN-VAP \\
SN-EQUIL \\
DSRPMIX \\
VAPOR
\end{tabular} & \begin{tabular}{|l|} 
STNDPIPE \\
ZNSCOOLR \\
STANDPIP \\
MISSING
\end{tabular} & \begin{tabular}{|l} 
SULFUR \\
VAPORIZR \\
LIQUID
\end{tabular} & $\begin{array}{l}\text { Display ALLS } \\
\text { Units: } \\
\text { Format: SOLI } \\
\end{array}$ & $\begin{array}{l}\text { TREAMS } \\
\text { From } \\
\text { DS To } \\
\text { Phas }\end{array}$ \\
\hline & & \begin{tabular}{|r|}
207.6 \\
\end{tabular} & \begin{tabular}{|r|}
146.5 \\
\end{tabular} & \begin{tabular}{|r|}
458.8 \\
\end{tabular} & $\begin{array}{r}814.4 \\
\end{array}$ & & \begin{tabular}{|r|}
600 \\
\end{tabular} & \begin{tabular}{|r|}
557.2 \\
\end{tabular} & $\begin{array}{r}557.2 \\
\end{array}$ & & $\begin{array}{r}600 \\
\end{array}$ & & & & \\
\hline Pressure & {$[\mathrm{PSI}]$} & 278.9 & 275 & 275 & 273.6 & 271.6 & 268.6 & 274.4 & 271.6 & & 268.6 & 275 & 14.7 & Pressure & [PSI] \\
\hline Mass VFrac & & 1 & & 1 & 1 & 1 & 1 & 1 & 1 & & 1 & 0 & & Mass VFrac & \\
\hline Mass SFrac & & 0 & 0 & 0 & 0 & 0 & 0 & 0 & 0 & & 0 & 4 & & Mass SFrac & \\
\hline$\overline{\star \star *}^{\star \star *}$ ALL PHAS & $E S^{* \star *}$ & & & & & & & & & & & & & 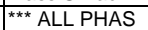 & $E S^{* \star *}$ \\
\hline Mass Flow & {$[\mathrm{LB} / \mathrm{HR}]$} & 38308.016 & 48507.805 & 508959.5 & 41294.703 & 41294.703 & 55125.902 & 13831.278 & 13831.278 & 0 & 55125.902 & 669963.875 & 6002.956 & Mass Flow & {$[\mathrm{LB} / \mathrm{HR}]$} \\
\hline Volume Flow & [CUFT/HR] & 44510.953 & 48127.191 & $1.20 \mathrm{E}+06$ & 95300.984 & 76325.195 & 109933.391 & 37429.125 & 37813.297 & & 109933.273 & 3189.083 & 33.124 & Volume Flow & [CUFT/HR] \\
\hline Enthalpy & {$[\mathrm{BTU} / \mathrm{HR}]$} & $3.05 \mathrm{E}+06$ & $-7.15 \mathrm{E}+07$ & $-1.16 \mathrm{E}+09$ & $-9.58 \mathrm{E}+06$ & $-1.38 \mathrm{E}+07$ & $-6.05 \mathrm{E}+07$ & $-3.13 E+07$ & -31319000 & $0.00 \mathrm{E}+00$ & $-6.05 \mathrm{E}+07$ & $-3.69 E+09$ & $-4.57 \mathrm{E}+05$ & Enthalpy & {$[\mathrm{BTU} / \mathrm{HR}]$} \\
\hline Density & [LB/CUFT] & 0.861 & 1.008 & $\begin{array}{l}0.423 \\
\end{array}$ & 0.433 & 0.541 & 0.501 & 0.37 & 0.366 & & 0.501 & 210.08 & 181.225 & & [LB/CUFT] \\
\hline Mass Flow & {$[\mathrm{LB} / \mathrm{HR}]$} & & & & & & & & & & & & & Mass Flow & {$[\mathrm{LB} / \mathrm{HR}]$} \\
\hline $\mathrm{O} 2 \mathrm{~S}$ & & & 63.71 & 63.71 & 11909.276 & 11909.276 & 63.879 & 1.742 & 1.742 & & 63.879 & & 0.001 & $\mathrm{O} 2 \mathrm{~S}$ & \\
\hline $\mathrm{H} 2 \mathrm{~S}$ & & & 71.964 & 6342.445 & & & 72.073 & 0.186 & 0.186 & & $\begin{array}{l}72.072 \\
\end{array}$ & & $<0.001$ & $\mathrm{H} 2 \mathrm{~S}$ & \\
\hline $\mathrm{H} 2 \mathrm{O}$ & & & 4208.244 & 74733.492 & & & 4963.325 & 2134.462 & 2134.462 & & 4963.325 & & $\begin{array}{r}146.193 \\
\end{array}$ & $\mathrm{H} 2 \mathrm{O}$ & \\
\hline S2 & & & $<0.001$ & $<0.001$ & & & 2631.176 & trace & trace & & 2631.176 & & 0.212 & 52 & \\
\hline 56 & & & 0.39 & 0.39 & & & 1891.255 & 0.011 & 0.011 & & 1891.255 & & 724.696 & 56 & \\
\hline 58 & & & 2.764 & 2.764 & & & 1339.271 & 0.076 & 0.076 & & 1339.271 & & 5131.851 & S8 & \\
\hline $\mathrm{CO}$ & & & 2.262 & 218164.266 & & & 2.262 & 5963.741 & 5963.741 & & 2.262 & & trace & $\mathrm{CO}$ & \\
\hline $\mathrm{CO} 2$ & & & 12925.476 & 130332.672 & & & 12929.425 & 3562.775 & 3562.775 & & 12929.425 & & 0.002 & $\mathrm{CO} 2$ & \\
\hline $\mathrm{H} 2$ & & & 0.85 & \begin{tabular}{|l|l|}
11766.221 \\
\end{tabular} & & & 0.85 & 321.642 & 321.642 & & 0.85 & & trace & $\mathrm{H} 2$ & \\
\hline$\overline{\mathrm{O} 2}$ & & 8922.588 & & & & & & & & & & & & $\mathrm{O} 2$ & \\
\hline N2 & & 29385.428 & 31231.822 & 67553.203 & 29385.428 & 29385.428 & 31232.063 & 1846.635 & 1846.635 & & 31232.063 & & trace & N2 & \\
\hline $\cos$ & & & 0.323 & 0.323 & & & 0.323 & 0.009 & 0.009 & & 0.323 & & trace & $\cos$ & \\
\hline ZNO & & & & & & & & & & & & & & ZNO & \\
\hline ZNS & & & & & & & & & & & & 144457.359 & & ZNS & \\
\hline AL2O3 & & & & & & & & & & & & 525506.5 & & AL2O3 & \\
\hline
\end{tabular}


DSRP 12/20/97 pg.3

\begin{tabular}{|c|c|c|c|c|c|c|c|c|c|c|c|c|c|}
\hline $\begin{array}{l}\text { Display ALLS } \\
\text { Units: } \\
\text { Format: SOLI } \\
\\
\text { Temperature }\end{array}$ & $\begin{array}{l}\text { TREAMS } \\
\text { From } \\
\text { DS To } \\
\text { Phas } \\
\text { [C] }\end{array}$ & $\begin{array}{|ll|}\text { TAILGAS } & \\
\text { COND-II } & \\
\text { VALVE } & \\
\text { VAPOR } & \\
& \end{array}$ & \begin{tabular}{|l|} 
TAILGAS2 \\
VALVE \\
RECYCOMP \\
VAPOR \\
\multicolumn{1}{c|}{139.9} \\
\end{tabular} & \begin{tabular}{|l|} 
TO-VAP \\
COND-II \\
VAPORIZR \\
LIQUID \\
\end{tabular} & \begin{tabular}{|l|} 
VENT \\
VAPORIZR \\
VAPOR \\
\end{tabular} & $\begin{array}{l}\text { XO2LIQ } \\
\text { DSRPXO2 } \\
\text { DSRP } \\
\text { MISSING }\end{array}$ & \begin{tabular}{|l|l} 
XO2VAP \\
DSRPXO2 \\
DSRP \\
VAPOR \\
\end{tabular} & \begin{tabular}{|l|} 
ZNO \\
REGENSEP \\
DESULF \\
MISSING \\
$\quad 814.4$ \\
\end{tabular} & \begin{tabular}{|l|} 
ZNS \\
DESULSEP \\
ZNSCOOLR \\
MISSING \\
557.2 \\
\end{tabular} & \begin{tabular}{|l|} 
ZNS-RECY \\
STANDPIP \\
DESULF \\
MISSING \\
\multicolumn{2}{|c|}{557.2} \\
\end{tabular} & \begin{tabular}{|l|} 
ZNS2RGEN \\
STANDPIP \\
REGEN \\
MISSING \\
\multicolumn{1}{|c|}{557.2} \\
\end{tabular} & $\begin{array}{l}\text { Display ALLS } \\
\text { Units: } \\
\text { Format: SOLI } \\
\text { Temperature }\end{array}$ & $\begin{array}{l}\text { TREAMS } \\
\text { From } \\
\text { DS To } \\
\text { Phas } \\
\text { [C] }\end{array}$ \\
\hline$\frac{\text { Iemperature }}{\text { Pressure }}$ & {$[\mathrm{C}]$} & $\begin{array}{r}140 \\
264.4 \\
\end{array}$ & $\begin{array}{r}139.9 \\
262 \\
\end{array}$ & \begin{tabular}{|r|}
140 \\
264.4 \\
\end{tabular} & \begin{tabular}{|r|}
140 \\
14.7 \\
\end{tabular} & & $\begin{array}{r}6000 \\
268.6 \\
\end{array}$ & \begin{tabular}{|r|}
273.6 \\
\end{tabular} & $\begin{array}{r}55 / .2 \\
274.4 \\
\end{array}$ & $\begin{array}{r}55 / .2 \\
275 \\
\end{array}$ & \begin{tabular}{|r|}
$55 / 2$ \\
275 \\
\end{tabular} & $\begin{array}{l}\text { Iemperature } \\
\text { Pressure }\end{array}$ & $\frac{[\mathrm{C}]}{[\mathrm{PSI}]}$ \\
\hline Mass VFrac & & 1 & 1 & 0 & 1 & & 1 & 0 & 0 & 0 & 0 & Mass VFrac & \\
\hline Mass SFrac & & 0 & 0 & 0 & 0 & & 0 & 1 & 1 & 1 & 1 & Mass SFrac & \\
\hline$\overline{\star \star *}^{\star \star *}$ ALL PHAS & $E S^{\star \star *}$ & & & & & & & & & & & ${ }^{* \star *}$ ALL PHAS & $E S^{\star \star \star}$ \\
\hline Mass Flow & [LB/HR] & 48507.805 & 48507.805 & 6618.099 & 615.143 & 0 & 55126.27 & 248249.766 & 669963.875 & 418727.406 & 251236.453 & Mass Flow & [LB/HR] \\
\hline Volume Flow & [CUFT/HR] & 49255.441 & 49703.582 & 46.323 & 18288.283 & & 118222.719 & 1195.906 & 3189.083 & 1993.177 & 1195.906 & Volume Flow & [CUFT/HR] \\
\hline Enthalpy & [BTU/HR] & $-7.17 \mathrm{E}+07$ & $-7.17 \mathrm{E}+07$ & -4482800 & $-3.48 \mathrm{E}+06$ & $0.00 \mathrm{E}+00$ & $-4.54 \mathrm{E}+07$ & $-1.37 E+09$ & $-3.69 E+09$ & -2307300000 & $-1.38 E+09$ & Enthalpy & {$[\mathrm{BTU} / \mathrm{HR}]$} \\
\hline Density & [LB/CUFT] & 0.985 & 0.976 & 142.868 & 0.034 & & 0.466 & 207.583 & $\begin{array}{r}210.08 \\
\end{array}$ & \begin{tabular}{|l|}
210.08 \\
\end{tabular} & $\begin{array}{r}210.08 \\
\end{array}$ & Density & [LB/CUFT] \\
\hline Mass Flow & {$[\mathrm{LB} / \mathrm{HR}]$} & & & & & & & & & & & Mass Flow & {$[\mathrm{LB} / \mathrm{HR}]$} \\
\hline $\mathrm{O} 2 \mathrm{~S}$ & & 63.71 & 63.71 & 0.17 & 0.169 & & \begin{tabular}{|l|l|}
11911.018 \\
\end{tabular} & & & & & $\mathrm{O} 2 \mathrm{~S}$ & \\
\hline $\mathrm{H} 2 \mathrm{~S}$ & & 71.964 & 71.964 & 0.109 & 0.109 & & 0.186 & & & & & $\mathrm{H} 2 \mathrm{~S}$ & \\
\hline $\mathrm{H} 2 \mathrm{O}$ & & 4208.244 & 4208.244 & 755.081 & 608.888 & & 1209.115 & & & & & $\mathrm{H} 2 \mathrm{O}$ & \\
\hline S2 & & $<0.001$ & $<0.001$ & 0.212 & $<0.001$ & & trace & & & & & $\mathrm{S2}$ & \\
\hline 56 & & 0.39 & 0.39 & 724.917 & \begin{tabular}{|l|}
0.221 \\
\end{tabular} & & 0.011 & & & & & S6 & \\
\hline 58 & & 2.764 & 2.764 & 5133.418 & \begin{tabular}{|r|}
1.567 \\
\end{tabular} & & $\begin{array}{l}0.076 \\
\end{array}$ & & & & & S8 & \\
\hline $\mathrm{CO}$ & & 2.262 & 2.262 & $<0.001$ & $<0.001$ & & 4524.921 & & & & & $\mathrm{CO}$ & \\
\hline $\mathrm{CO} 2$ & & 12925.476 & 12925.476 & 3.95 & 3.948 & & 5823.677 & & & & & $\mathrm{CO} 2$ & \\
\hline $\mathrm{H} 2$ & & 0.85 & 0.85 & $<0.001$ & $<0.001$ & & 425.192 & & & & & $\mathrm{H} 2$ & \\
\hline $\mathrm{O} 2$ & & & & & & & & & & & & $\mathrm{O} 2$ & \\
\hline N2 & & 31231.822 & 31231.822 & 0.241 & \begin{tabular}{|l|}
0.241 \\
\end{tabular} & & 31232.063 & & & & & N2 & \\
\hline $\cos$ & & 0.323 & 0.323 & $<0.001$ & $<0.001$ & & 0.009 & & & & & $\cos$ & \\
\hline ZNO & & & & & & & & 15129.819 & & & & ZNO & \\
\hline
\end{tabular}




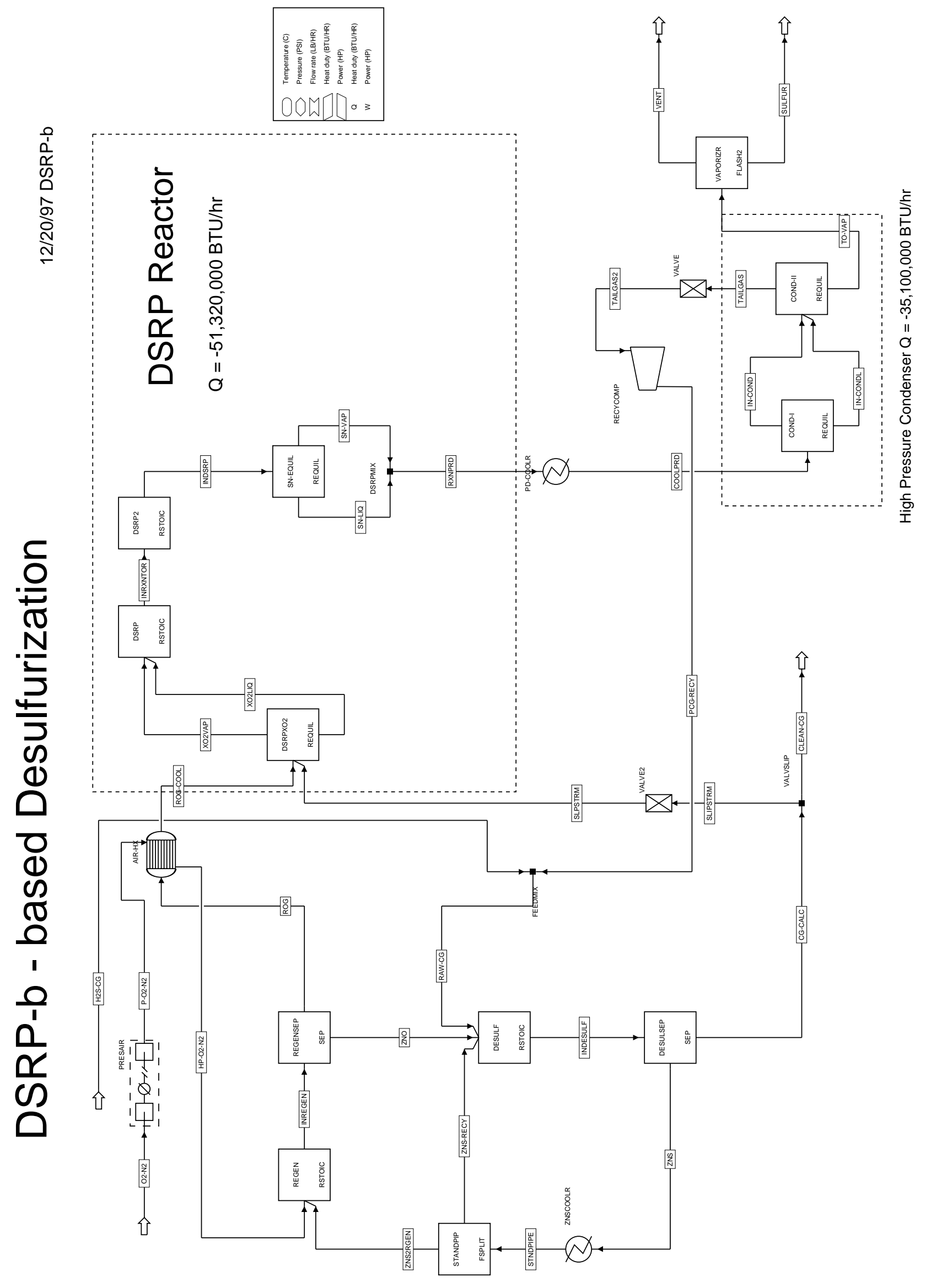


DSRP-b 12/20/97 pg1

\begin{tabular}{|c|c|c|c|c|c|c|c|c|c|c|c|c|c|c|c|}
\hline $\begin{array}{l}\text { Display ALLS } \\
\text { Units: } \\
\text { Format: SOLI }\end{array}$ & $\begin{array}{l}\text { TREAMS } \\
\text { From } \\
\text { DS To } \\
\text { Phas }\end{array}$ & \begin{tabular}{|l|} 
CG-CALC \\
DESULSEP \\
VALVSLIP \\
VAPOR \\
\end{tabular} & \begin{tabular}{|l} 
CLEAN-CG \\
VALVSLIP \\
VAPOR
\end{tabular} & $\begin{array}{l}\text { COOLPRD } \\
\text { PD-COOLR } \\
\text { COND-I } \\
\text { VAPOR }\end{array}$ & \begin{tabular}{|l|} 
H2S-CG \\
FEEDMIX \\
VAPOR
\end{tabular} & $\begin{array}{l}\text { HP-O2-N2 } \\
\text { AIR-HX } \\
\text { REGEN } \\
\text { VAPOR }\end{array}$ & \begin{tabular}{|l|} 
IN-COND \\
COND-I \\
COND-II \\
VAPOR
\end{tabular} & \begin{tabular}{|l|} 
IN-CONDL \\
COND-I \\
COND-II \\
LIQUID
\end{tabular} & \begin{tabular}{|l||} 
INDESULF \\
DESULF \\
DESULSEP \\
VAPOR \\
\end{tabular} & \begin{tabular}{|l|} 
INDSRP \\
DSRP2 \\
SN-EQUIL \\
VAPOR
\end{tabular} & \begin{tabular}{|l|} 
INREGEN \\
REGEN \\
REGENSEP \\
VAPOR
\end{tabular} & \begin{tabular}{|l|} 
INRXNTOR \\
DSRP \\
DSRP2 \\
VAPOR
\end{tabular} & $\begin{array}{l}\text { O2-N2 } \\
\text { PRESAIR } \\
\text { VAPOR }\end{array}$ & $\begin{array}{l}\text { Display ALLS } \\
\text { Units: } \\
\text { Format: SOLI } \\
\end{array}$ & $\begin{array}{l}\text { TREAMS } \\
\text { From } \\
\text { DS To } \\
\text { Phas } \\
C l\end{array}$ \\
\hline $\begin{array}{l}\text { Temperature } \\
\text { Pressure }\end{array}$ & {$\left[\begin{array}{l}\text { [C] } \\
\text { [PSI] }\end{array}\right.$} & $\begin{array}{l}44.5 \\
273.6 \\
\end{array}$ & $\begin{array}{l}6473.5 \\
273.6\end{array}$ & $\begin{array}{r}4115 \\
265.6\end{array}$ & $\begin{array}{r}428.2 \\
275 \\
\end{array}$ & $\begin{array}{r}450 \\
277.4\end{array}$ & $\begin{array}{r}140 \\
263.6\end{array}$ & $\begin{array}{r}140 \\
263.6 \\
\end{array}$ & $\begin{array}{l}047.5 \\
273.6 \\
\end{array}$ & $\begin{array}{r}007.6 \\
\end{array}$ & \begin{tabular}{|r|} 
\\
272.6
\end{tabular} & $\begin{array}{r}000 \\
267.6\end{array}$ & 13.7 & Pressure & {$[\mathrm{PSI}]$} \\
\hline Mass VFrac & & & 1 & 1 & 1 & 1 & 1 & 0 & 0.197 & 1 & 0.099 & 1 & & Mass VFrac & \\
\hline Mass SFrac & & 0 & 0 & 0 & 0 & 0 & 0 & 0 & 0.803 & 0 & 0.901 & 0 & & Mass SFrac & \\
\hline *t* ALL PHAS & $E S^{\star \star \star}$ & & & & & & & & & & & & & *** ALL PHAS & $E S^{\star \star \star}$ \\
\hline Mass Flow & [LB/HR] & 655189.75 & 601554.75 & 184610.219 & 501234.031 & 121500 & 163323.219 & 21287.002 & 3324180 & 184607.219 & 1322550 & \begin{tabular}{l|l}
184607.719 \\
\end{tabular} & 121500 & Mass Flow & {$[\mathrm{LB} / \mathrm{HR}]$} \\
\hline Volume Flow & [CUFT/HR] & 1887870 & 1733330 & 294846.875 & 1244460 & 213489.484 & $\begin{array}{l}166528.75 \\
\end{array}$ & 159.053 & 1900580 & $\begin{array}{l}378670.75 \\
\end{array}$ & 307882.375 & 376264.813 & 1799510 & Volume Flow & [CUFT/HR] \\
\hline Enthalpy & {$[\mathrm{BTU} / \mathrm{HR}]$} & $-1.36 \mathrm{E}+09$ & $-1.24 \mathrm{E}+09$ & $-2.24 \mathrm{E}+08$ & $-1.16 \mathrm{E}+09$ & $2.32 \mathrm{E}+07$ & $-2.43 E+08$ & $-1.61 \mathrm{E}+07$ & $-1.60 E+10$ & $-2.00 \mathrm{E}+08$ & $-6.55 E+09$ & $-1.99 \mathrm{E}+08$ & $2.51 \mathrm{E}+05$ & Enthalpy & {$[\mathrm{BTU} / \mathrm{HR}]$} \\
\hline Density & [LB/CUFT] & 0.347 & 0.347 & 0.626 & 0.403 & 0.569 & 0.981 & 133.836 & 1.749 & 0.488 & 4.296 & 0.491 & 0.068 & Density & [LB/CUFT] \\
\hline Mass Flow & {$[\mathrm{LB} / \mathrm{HR}]$} & & & & & & & & & & & & & Mass Flow & {$[\mathrm{LB} / \mathrm{HR}]$} \\
\hline O2S & & 194.606 & 178.675 & 195.105 & & & 194.579 & 0.526 & 194.606 & 195.105 & 37772.176 & 5444.741 & & $\mathrm{O} 2 \mathrm{~S}$ & \\
\hline H2S & & $\begin{array}{r}14.000 \\
62.453 \\
\end{array}$ & 57.341 & $\begin{array}{r}240.340 \\
240.342\end{array}$ & 19916.91 & & \begin{tabular}{|l|}
239.971 \\
239.9
\end{tabular} & $\begin{array}{l}0.520 \\
0.371\end{array}$ & $\frac{14.000}{62.453}$ & $\frac{19.103}{240.342}$ & & $\begin{array}{r}444 . .141 \\
240.342 \\
\end{array}$ & & H2S & \\
\hline $\mathrm{H} 2 \mathrm{O}$ & & 99935.453 & \begin{tabular}{|l}
91754.563 \\
\end{tabular} & 17155.324 & 74738.914 & & \begin{tabular}{|l|}
14470.859 \\
\end{tabular} & 2684.464 & \begin{tabular}{|l|}
99935.453 \\
\end{tabular} & 17155.324 & & 17155.324 & & $\mathrm{H} 2 \mathrm{O}$ & \\
\hline S2 & & $<0.001$ & $<0.001$ & 8658.119 & & & $<0.001$ & $\begin{array}{r}004.4095 \\
0.695\end{array}$ & $<0.001$ & 18593.258 & & 10711.036 & & S2 & \\
\hline 56 & & 1.28 & 1.175 & 5885.709 & & & 3.086 & 5882.623 & 1.28 & 0.105 & & 0.105 & & S6 & \\
\hline S8 & & 8.967 & 8.233 & 4053.262 & & & 6.665 & \begin{tabular}{|l|}
12704.021 \\
\end{tabular} & 8.967 & 0.734 & & 0.734 & & S8 & \\
\hline $\mathrm{CO}$ & & 231203.391 & 212276.672 & 6.89 & 231196.5 & & 6.89 & $<0.001$ & 231203.391 & 6.89 & & 6.89 & & $\mathrm{CO}$ & \\
\hline $\mathrm{CO} 2$ & & 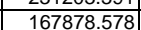 & 154135.734 & $\begin{array}{r}0.03469 .434 \\
434\end{array}$ & 124421.914 & & \begin{tabular}{r|}
0.953455 .953 \\
43
\end{tabular} & 13.482 & $\frac{167878.578}{1678}$ & $\begin{array}{r}43469.434 \\
\end{array}$ & & 36256.879 & & $\mathrm{CO} 2$ & \\
\hline $\mathrm{H} 2$ & & $\begin{array}{l}12471.098 \\
\end{array}$ & 11450.191 & $\begin{array}{r}2.783 \\
\end{array}$ & 12468.315 & & $\begin{array}{r}2.783 \\
\end{array}$ & $<0.001$ & $\begin{array}{l}12471.098 \\
\end{array}$ & 2.783 & & 2.783 & & $\mathrm{H} 2$ & \\
\hline $\mathrm{O} 2$ & & & & & & 28299.416 & & & & & & & 28299.416 & $\mathrm{O} 2$ & \\
\hline N2 & & 143432.969 & 131691.281 & 104942.266 & 38491.473 & 93200.586 & 104941.445 & 0.818 & 143432.969 & 104942.266 & 93200.586 & 104942.266 & 93200.586 & & \\
\hline $\cos$ & & 0.984 & 0.904 & 0.985 & & & 0.984 & $<0.001$ & 0.984 & 0.985 & & 9846.616 & & $\cos$ & \\
\hline $\begin{array}{l}\mathrm{ZNO} \\
\end{array}$ & & & & & & & & & & & 47986.641 & & & ZNO & \\
\hline ZNS & & & & & & & & & 576614.875 & & 202017.281 & & & ZNS & \\
\hline AL2O3 & & & & & & & & & 2092380 & & 941570.188 & & & $\mathrm{AL} 2 \mathrm{O} 3$ & \\
\hline
\end{tabular}


DSRP-b 12/20/97 pg.2

\begin{tabular}{|c|c|c|c|c|c|c|c|c|c|c|c|c|c|c|c|}
\hline $\begin{array}{l}\text { Display ALLS } \\
\text { Units: } \\
\text { Format: SOLI } \\
\\
\text { Temperature }\end{array}$ & $\begin{array}{l}\text { TREAMS } \\
\text { From } \\
\text { DS To } \\
\text { Phas } \\
\text { [C] }\end{array}$ & $\mid$\begin{tabular}{|l|} 
P-O2-N2 \\
PRESAIR \\
AIR-HX \\
VAPOR \\
$\quad 207.7$
\end{tabular} & \begin{tabular}{l} 
PCG-RECY \\
RECYCOMP \\
FEEDMIX \\
VAPOR \\
\multicolumn{1}{l}{147.5}
\end{tabular} & \begin{tabular}{|l|} 
RAW-CG \\
FEEDMIX \\
DESULF \\
VAPOR \\
$\quad 418.7$
\end{tabular} & \begin{tabular}{|l} 
ROG \\
REGENSEP \\
AIR-HX \\
VAPOR \\
\\
\end{tabular} & \begin{tabular}{l} 
ROG-COOL \\
AIR-HX \\
DSRPXO2 \\
VAPOR \\
\multicolumn{1}{|c}{586.3}
\end{tabular} & \begin{tabular}{|l|} 
RXNPRD \\
DSRPMIX \\
PD-COOLR \\
VAPOR \\
\end{tabular} & \begin{tabular}{|l|} 
SLIPSTRM \\
VALVSLIP \\
VALVE2 \\
VAPOR \\
$\quad 647.5$
\end{tabular} & $\begin{array}{l}\text { SLPSTRM } \\
\text { VALVE2 } \\
\text { DSRPXO2 } \\
\text { VAPOR } \\
\quad 647.5\end{array}$ & $\begin{array}{l}\text { SN-LIQ } \\
\text { SN-EQUIL } \\
\text { DSRPMIX } \\
\text { MISSING }\end{array}$ & \begin{tabular}{|l} 
SN-VAP \\
SN-EQUIL \\
DSRPMIX \\
VAPOR \\
\end{tabular} & \begin{tabular}{|l|} 
STNDPIPE \\
ZNSCOOLR \\
STANDPIP \\
MISSING \\
$\quad 640$
\end{tabular} & $\mid \begin{array}{ll}\text { SULFUR } & \\
\text { VAPORIZR } \\
\text { LIQUID } \\
& \\
& 140\end{array}$ & $\begin{array}{l}\text { Display ALLS } \\
\text { Units: } \\
\text { Format: SOLI } \\
\\
\text { Temperature }\end{array}$ & $\begin{array}{l}\text { TREAMS } \\
\text { From } \\
\text { DS To } \\
\text { Phas } \\
\text { [C] }\end{array}$ \\
\hline Pressure & [PSI] & 201.4 & $\begin{array}{r}14 / .5 \\
275 \\
\end{array}$ & $\frac{418.1}{275}$ & $\begin{array}{r}810 \\
272.6\end{array}$ & $\frac{580.3}{270.6}$ & 267.6 & $\frac{64 / .5}{273.6}$ & $\frac{64 / .5}{270.6}$ & & 2600 & $\begin{array}{l}640 \\
275 \\
\end{array}$ & \begin{tabular}{|r|}
140 \\
14.7
\end{tabular} & \begin{tabular}{|l} 
Temperature \\
Pressure
\end{tabular} & $\frac{[\mathrm{C}]}{[\mathrm{PSI}}$ \\
\hline Mass VFrac & & 1 & 1 & 1 & & 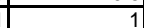 & 1 & 1 & 1 & & 1 & 0 & & Mass VFrac & \\
\hline Mass SFrac & & 0 & 0 & 0 & 0 & 0 & 0 & 0 & 0 & & 0 & 1 & & Mass SFrac & \\
\hline *** ALL PHAS & $E S^{* * *}$ & & & & & & & & & & & & & ${ }^{* * *}$ ALL PHAS & $E S^{* * *}$ \\
\hline Mass Flow & {$[\mathrm{LB} / \mathrm{HR}]$} & 121500 & 163428.5 & 664662.5 & 130972.758 & 130972.758 & 184610.219 & 53635.004 & 53635.004 & 0 & 184610.219 & 2668990 & 19044.756 & Mass Flow & {$[\mathrm{LB} / \mathrm{HR}]$} \\
\hline Volume Flow & [CUFT/HR] & 140938.547 & 162790.359 & 1410320 & 302165.188 & 241725.797 & 372001.438 & 154544.391 & 156250.734 & & 372001.031 & 12704.87 & 105.13 & Volume Flow & [CUFT/HR] \\
\hline Enthalpy & {$[\mathrm{BTU} / \mathrm{HR}]$} & 9691570 & $-2.43 \mathrm{E}+08$ & $-1.40 \mathrm{E}+09$ & $-3.07 \mathrm{E}+07$ & $-4.42 \mathrm{E}+07$ & $-2.06 \mathrm{E}+08$ & $-1.11 \mathrm{E}+08$ & $-1.11 \mathrm{E}+08$ & 0 & $-2.06 \mathrm{E}+08$ & $-1.46 \mathrm{E}+10$ & $-1.45 \mathrm{E}+06$ & Enthalpy & {$[\mathrm{BTU} / \mathrm{HR}]$} \\
\hline \begin{tabular}{|l|l} 
Density \\
\end{tabular} & [LB/CUFT] & 0.862 & $\begin{array}{r}1.004 \\
\end{array}$ & 0.471 & 0.433 & $\frac{0.542}{0.42}$ & $\begin{array}{r}0.006 \\
\end{array}$ & 0.347 & 0.343 & & $\begin{array}{r}0.496 \\
\end{array}$ & 21.40.076 & 181.154 & \begin{tabular}{|l} 
Density \\
\end{tabular} & [LB/CUFT] \\
\hline Mass Flow & {$[\mathrm{LB} / \mathrm{HR}]$} & & & & & & & & & & & & & \begin{tabular}{|l|l|l|l} 
Mass Flow \\
\end{tabular} & {$[\mathrm{LB} / \mathrm{HR}]$} \\
\hline $\mathrm{O} 2 \mathrm{~S}$ & & & 194.606 & 194.606 & 37772.176 & 37772.176 & 195.105 & 15.931 & 15.931 & & 195.105 & & 0.002 & $\mathrm{O} 2 \mathrm{~S}$ & \\
\hline $\mathrm{H} 2 \mathrm{~S}$ & & & 239.99 & 20156.9 & & & 240.342 & 5.113 & 5.113 & & 240.342 & & 0.001 & $\mathrm{H} 2 \mathrm{~S}$ & \\
\hline $\mathrm{H} 2 \mathrm{O}$ & & & \begin{tabular}{|r|}
14574.853 \\
\end{tabular} & \begin{tabular}{|l|}
89313.766 \\
\end{tabular} & & & 17155.324 & \begin{tabular}{|l|}
8180.895 \\
\end{tabular} & 8180.895 & & 17155.324 & & 464.116 & $\mathrm{H} 2 \mathrm{O}$ & \\
\hline S2 & & & $<0.001$ & $<0.001$ & & & 8658.119 & $<0.001$ & $<0.001$ & & 8658.119 & & 0.695 & S2 & \\
\hline S6 & & & 1.28 & 1.28 & & & 5885.709 & 0.105 & 0.105 & & 5885.709 & & 2321.039 & S6 & \\
\hline S8 & & & 8.967 & 8.967 & & & 4053.262 & 0.734 & 0.734 & & 4053.262 & & 16258.897 & 58 & \\
\hline CO & & & 6.89 & 231203.391 & & & 6.89 & 18926.723 & 18926.723 & & 6.89 & & trace & $\begin{array}{ll}\mathrm{CO} \\
\end{array}$ & \\
\hline $\mathrm{CO} 2$ & & & 43456.652 & 167878.578 & & & 43469.434 & 13742.839 & 13742.839 & & 43469.434 & & 0.006 & $\mathrm{CO} 2$ & \\
\hline $\mathrm{H} 2$ & & & 2.783 & 12471.098 & & & 2.783 & 1020.906 & 1020.906 & & 2.783 & & trace & $\mathrm{H} 2$ & \\
\hline $\mathrm{O} 2$ & & 28299.416 & & & & & & & & & & & & $\mathrm{O} 2$ & \\
\hline N2 & & 93200.586 & 104941.492 & 143432.969 & 93200.586 & 93200.586 & 104942.266 & 11741.678 & 11741.678 & & 104942.266 & & $<0.001$ & N2 & \\
\hline $\cos$ & & & 0.984 & 0.984 & & & 0.985 & 0.081 & 0.081 & & 0.985 & & trace & $\cos$ & \\
\hline ZNO & & & & & & & & & & & & & & ZNNO & \\
\hline ZNS & & & & & & & & & & & & 576614.875 & & ZNS & \\
\hline AL2O3 & & & & & & & & & & & & 2092380 & & $\begin{array}{l}\text { AL2O3 } \\
\end{array}$ & \\
\hline
\end{tabular}


DSRP-b 12/20/97 pg.3

\begin{tabular}{|c|c|c|c|c|c|c|c|c|c|c|c|c|c|}
\hline $\begin{array}{l}\text { Display ALLS } \\
\text { Units: } \\
\text { Format: SOLI } \\
\\
\text { Temperature }\end{array}$ & $\begin{array}{l}\text { TREAMS } \\
\text { From } \\
\text { DS To } \\
\text { Phas } \\
\text { [C] }\end{array}$ & $\mid$\begin{tabular}{|l|} 
TAILGAS \\
COND-II \\
VALVE \\
VAPOR \\
\\
\end{tabular} & $\mid$\begin{tabular}{l} 
TAILGAS2 \\
VALVE \\
RECYCOMP \\
VAPOR \\
\multicolumn{1}{|c|}{139.9}
\end{tabular} & $\mid \begin{array}{l}\text { TO-VAP } \\
\text { COND-II } \\
\text { VAPORIZR } \\
\text { LIQUID } \\
\end{array}$ & $\begin{array}{|ll|}\text { VENT } & \\
\text { VAPORIZR } \\
\text { VAPOR } \\
\\
\end{array}$ & \begin{tabular}{|l}
$\mathrm{XO2LIQ}$ \\
DSRPXO2 \\
DSRP \\
MISSING
\end{tabular} & 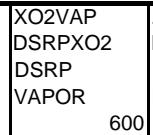 & \begin{tabular}{|l|} 
ZNO \\
REGENSEP \\
DESULF \\
MISSING \\
$\quad$ \\
$\quad 810$
\end{tabular} & \begin{tabular}{|l|} 
ZNS \\
DESULSEP \\
ZNSCOOLR \\
MISSING \\
$\quad 647.5$
\end{tabular} & $\begin{array}{l}\text { ZNS-RECY } \\
\text { STANDPIP } \\
\text { DESULF } \\
\text { MISSING }\end{array}$ & \begin{tabular}{|l|} 
ZNS2RGEN \\
STANDPIP \\
REGEN \\
MISSING \\
\multicolumn{1}{|c|}{640} \\
\end{tabular} & $\begin{array}{l}\text { Display ALLS } \\
\text { Units: } \\
\text { Format: SOLI } \\
\\
\text { Temperature }\end{array}$ & $\begin{array}{l}\text { TREAMS } \\
\text { From } \\
\text { DS To } \\
\text { Phas } \\
\text { [C] }\end{array}$ \\
\hline Pressure & {$[\mathrm{PSI}]$} & 263.6 & \begin{tabular}{|l|}
261 \\
\end{tabular} & $\begin{array}{r}1403.6 \\
\end{array}$ & $\begin{array}{r}140 \\
14.7\end{array}$ & & \begin{tabular}{|r|}
267.6 \\
\end{tabular} & \begin{tabular}{|r|} 
\\
\end{tabular} & 273.6 & 275 & \begin{tabular}{|l|}
5 \\
5
\end{tabular} & \begin{tabular}{|l} 
Pressure \\
\end{tabular} & {$[\mathrm{PSI}]$} \\
\hline Mass VFrac & & 1 & 1 & 0 & 1 & & 1 & 0 & 0 & 0 & 0 & Mass VFrac & \\
\hline Mass SFrac & & 0 & 0 & 0 & 0 & & 0 & 1 & 1 & 1 & 1 & Mass SFrac & \\
\hline$* * \star$ ALL PHAS & $\mathrm{ES}^{* * *}$ & & & & & & & & & & & $* * \star$ ALL PHAS & $\mathrm{ES}^{* \star *}$ \\
\hline Mass Flow & {$[\mathrm{LB} / \mathrm{HR}]$} & 163428.5 & 163428.5 & 21181.719 & 2136.962 & 0 & 184608.375 & 1191570 & 2668990 & 1467950 & 1201050 & Mass Flow & {$[\mathrm{LB} / \mathrm{HR}]$} \\
\hline Volume Flow & [CUFT/HR] & 166691.297 & 168340.75 & 150.956 & 63551.742 & & 398196.594 & 5717.191 & 12704.87 & 6987.678 & 5717.191 & Volume Flow & [CUFT/HR] \\
\hline Enthalpy & [BTU/HR] & $-2.43 \mathrm{E}+08$ & $-2.43 E+08$ & $\begin{array}{l}-1.54 \mathrm{E}+07 \\
\end{array}$ & $-1.21 \mathrm{E}+07$ & 0 & $-1.59 \mathrm{E}+08$ & $-6.52 E+09$ & $-1.46 E+10$ & $-8.03 \mathrm{E}+09$ & $-6.57 \mathrm{E}+09$ & \begin{tabular}{|l|} 
Enthalpy \\
\end{tabular} & {$[\mathrm{BTU} / \mathrm{HR}]$} \\
\hline Density & [LB/CUFT] & $\begin{array}{r}0.98 \mathrm{~T} \\
\end{array}$ & $\begin{array}{r}0.971 \\
\end{array}$ & 140.317 & 0.034 & & 0.464 & \begin{tabular}{|l|}
208.419 \\
\end{tabular} & 210.076 & $\frac{0.0076}{210.076}$ & 210.076 & \begin{tabular}{|l|} 
Density \\
\end{tabular} & [LB/CUFT] \\
\hline Mass Flow & {$[\mathrm{LB} / \mathrm{HR}]$} & & & & & & & & & & & Mass Flow & {$[\mathrm{LB} / \mathrm{HR}]$} \\
\hline $\mathrm{O} 2 \mathrm{~S}$ & & 194.606 & 194.606 & 0.499 & 0.497 & & 37788.105 & & & & & $\mathrm{O} 2 \mathrm{~S}$ & \\
\hline $\mathrm{H} 2 \mathrm{~S}$ & & 239.99 & 239.99 & 0.353 & 0.352 & & 5.113 & & & & & $\mathrm{H} 2 \mathrm{~S}$ & \\
\hline $\mathrm{H} 2 \mathrm{O}$ & & \begin{tabular}{|l|}
14574.853 \\
\end{tabular} & \begin{tabular}{|l|}
14574.853 \\
\end{tabular} & 2580.471 & \begin{tabular}{|l|}
2116.355 \\
\end{tabular} & & \begin{tabular}{|l|}
4870.572 \\
\end{tabular} & & & & & $\mathrm{H} 2 \mathrm{O}$ & \\
\hline S2 & & $\begin{array}{l}<0.001 \\
\end{array}$ & $<0.001$ & 0.695 & $<0.001$ & & $<0.001$ & & & & & S2 & \\
\hline S6 & & 1.28 & 1.28 & 2321.814 & \begin{tabular}{|l|}
0.776 \\
\end{tabular} & & \begin{tabular}{|l|}
0.105 \\
\end{tabular} & & & & & S6 & \\
\hline S8 & & 8.967 & 8.967 & 16264.332 & \begin{tabular}{|l|}
5.434 \\
\end{tabular} & & $\begin{array}{l}0.734 \\
\end{array}$ & & & & & \begin{tabular}{|l|} 
S8 \\
\end{tabular} & \\
\hline $\mathrm{CO}$ & & 6.89 & 6.89 & $<0.001$ & $<0.001$ & & \begin{tabular}{l|l|}
13779.622 \\
\end{tabular} & & & & & $\mathrm{CO}$ & \\
\hline $\mathrm{CO} 2$ & & 43456.652 & 43456.652 & \begin{tabular}{|l|l|}
12.781 \\
\end{tabular} & \begin{tabular}{|r|}
12.774 \\
\end{tabular} & & 21830.447 & & & & & \begin{tabular}{|l|}
$\mathrm{CO} 2$ \\
\end{tabular} & \\
\hline $\mathrm{H} 2$ & & 2.783 & 2.783 & $<0.001$ & $<0.001$ & & 1391.339 & & & & & $\mathrm{H} 2$ & \\
\hline $\mathrm{O} 2$ & & & & & & & & & & & & $\mathrm{O} 2$ & \\
\hline N2 & & 104941.492 & 104941.492 & 0.773 & 0.773 & & 104942.266 & & & & & N2 & \\
\hline $\cos$ & & 0.984 & 0.984 & $<0.001$ & $<0.001$ & & 0.081 & & & & & $\cos$ & \\
\hline ZNO & & & & & & & & 47986.641 & & & & ZNO & \\
\hline ZNS & & & & & & & & 202017.281 & 576614.875 & 317138.188 & 259476.688 & ZNS & \\
\hline AL2O3 & & & & & & & & 941570.188 & 2092380 & 1150810 & 941570.188 & AL2O3 & \\
\hline
\end{tabular}




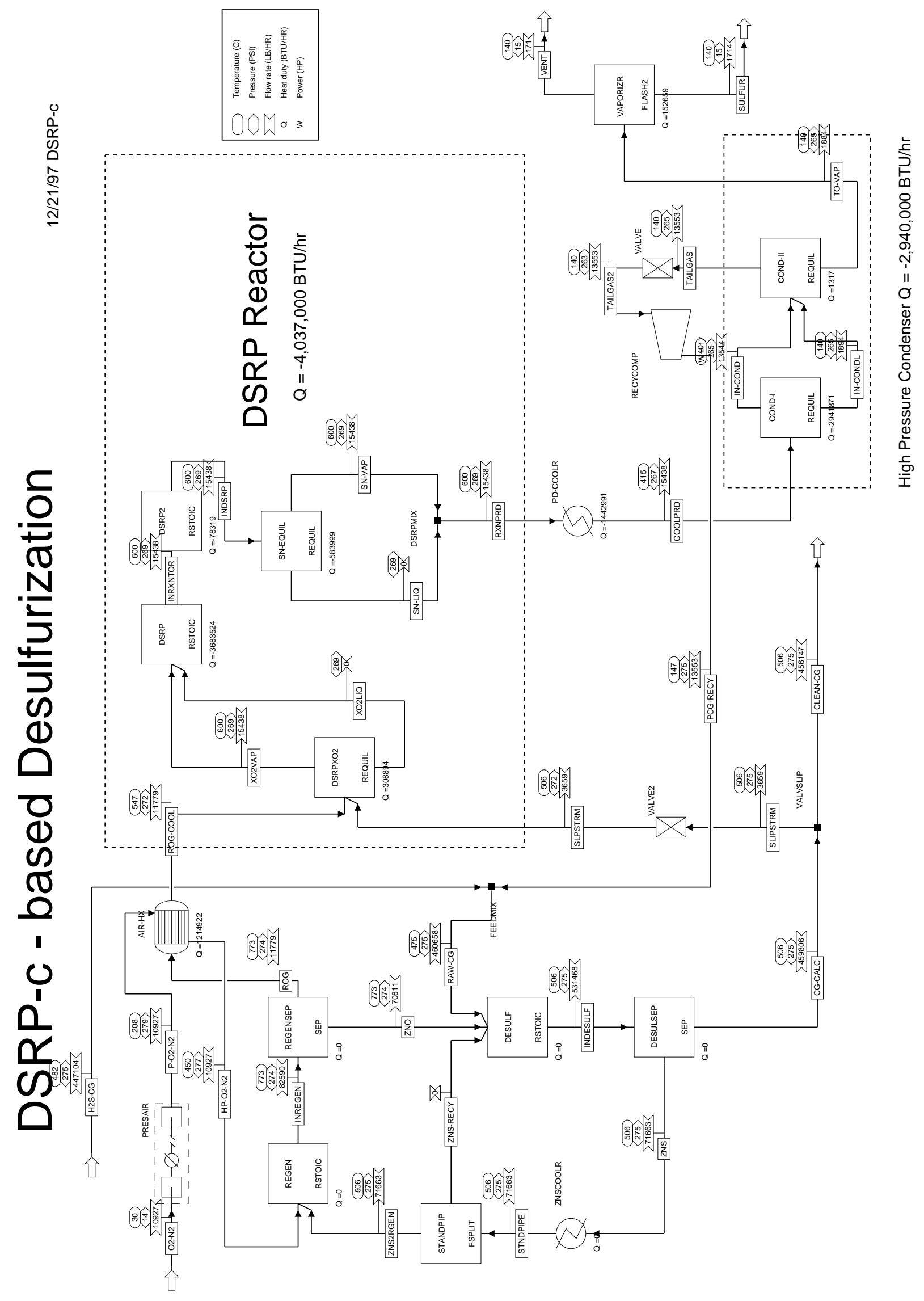


DSRP-c 12/21/97 pg.1

\begin{tabular}{|c|c|c|c|c|c|c|c|c|c|c|c|c|c|c|c|}
\hline $\begin{array}{l}\text { Display ALLS } \\
\text { Units: } \\
\text { Format: SOLI }\end{array}$ & $\begin{array}{l}\text { TREAMS } \\
\text { From } \\
\text { DS To } \\
\text { Phas }\end{array}$ & \begin{tabular}{|l|} 
CG-CALC \\
DESULSEP \\
VALVSLIP \\
VAPOR
\end{tabular} & \begin{tabular}{|l|} 
CLEAN-CG \\
VALVSLIP \\
VAPOR
\end{tabular} & \begin{tabular}{|l|} 
COOLPRD \\
PD-COOLR \\
COND-I \\
VAPOR \\
\end{tabular} & \begin{tabular}{|l|} 
H2S-CG \\
FEEDMIX \\
VAPOR
\end{tabular} & \begin{tabular}{|l|} 
HP-O2-N2 \\
AIR-HX \\
REGEN \\
VAPOR
\end{tabular} & \begin{tabular}{|l||} 
IN-COND \\
COND-I \\
COND-II \\
VAPOR
\end{tabular} & \begin{tabular}{|l|} 
IN-CONDL \\
COND-I \\
COND-II \\
LIQUID
\end{tabular} & \begin{tabular}{|l||} 
INDESUULF \\
DESULF \\
DESULSEP \\
VAPOR
\end{tabular} & \begin{tabular}{|l|} 
INDSRP \\
DSRP2 \\
SN-EQUIL \\
VAPOR
\end{tabular} & $\begin{array}{l}\text { INREGEN } \\
\text { REGEN } \\
\text { REGENSEP } \\
\text { VAPOR }\end{array}$ & \begin{tabular}{|l|} 
INRXNTOR \\
DSRP \\
DSRP2 \\
VAPOR \\
\end{tabular} & \begin{tabular}{|l|} 
O2-N2 \\
PRESAIR \\
VAPOR
\end{tabular} & \begin{tabular}{|l|} 
Display ALLS \\
Units: \\
Format: SOLI
\end{tabular} & $\begin{array}{l}\text { TREAMS } \\
\text { From } \\
\text { DS To } \\
\text { Phas }\end{array}$ \\
\hline Temperature & & & & & & & \begin{tabular}{|r|}
140 \\
\end{tabular} & \begin{tabular}{|r|}
140 \\
\end{tabular} & & $\begin{array}{l}600 \\
\end{array}$ & 772.6 & 600 & 30 & Temperature & \\
\hline Pressure & [PSI] & 274.9 & 274.9 & 267.1 & 275 & 277.3 & 265.1 & 265.1 & 274.9 & 269.1 & 274.1 & 269.1 & 13.7 & Pressure & {$[\mathrm{PSI}]$} \\
\hline Mass VFrac & & & & & & & & 0 & 0.865 & 1 & 0.143 & & & Mass VFrac & \\
\hline \begin{tabular}{|l|} 
Mass SFrac \\
\end{tabular} & & & 0 & 0 & 0 & 0 & 0 & 0 & 0.135 & 0 & 0.857 & & & Mass SFrac & \\
\hline ***A ALL PHAS & $E S^{* * *}$ & & & & & & & & & & & & & *** ALL PHAS & $E S^{* * *}$ \\
\hline Mass Flow & {$[\mathrm{LB} / \mathrm{HR}]$} & 459805.594 & 456146.75 & 15437.757 & 447104.125 & 10927 & 13544.205 & 1893.551 & 531468.188 & 15437.757 & 82589.578 & 15437.803 & $\begin{array}{r}10927 \\
\end{array}$ & Mass Flow & {$[\mathrm{LB} / \mathrm{HR}]$} \\
\hline Volume Flow & [CUFT/HR] & 1187320 & $\begin{array}{r}1177870 \\
1177\end{array}$ & 24296.518 & 1125490 & 19206.873 & 13705.025 & 13.869 & 1187660 & 31278.654 & 26436.727 & 31051.443 & $\begin{array}{l}161837.719 \\
\end{array}$ & Volume Flow & [CUFT/HR] \\
\hline Enthalpy & [BTU/HR] & $-1.08 \mathrm{E}+09$ & $-1.08 E+09$ & $-1.83 \mathrm{E}+07$ & $-1.07 E+09$ & $2.09 \mathrm{E}+06$ & $-1.99 E+07$ & $-1.30 \mathrm{E}+06$ & $-1.48 E+09$ & $-1.63 E+07$ & $-3.94 \mathrm{E}+08$ & $\begin{array}{l}-1.62 E+07 \\
\end{array}$ & $2.26 \mathrm{E}+04$ & & [BTU/HR] \\
\hline & [LB/CUFT] & 0.387 & 0.387 & 0.635 & 0.397 & 0.569 & 0.988 & 136.533 & 0.447 & 0.494 & 3.124 & 0.497 & 0.068 & & [LB/CUFT] \\
\hline Mass Flow & [LB/HR] & & & & & & & & & & & & & Mass Flow & {$[\mathrm{LB} / \mathrm{HR}]$} \\
\hline O2S & & 15.704 & & 15.747 & & & 15.702 & 0.045 & 15.704 & 15.747 & 3397.009 & 515.087 & & O2S & \\
\hline $\mathrm{H} 2 \mathrm{~S}$ & & 14.867 & 14.749 & 20.399 & 1801.676 & & 20.366 & 0.033 & 14.867 & 20.399 & & 20.399 & & $\mathrm{H} 2 \mathrm{~S}$ & \\
\hline $\mathrm{H} 2 \mathrm{O}$ & & 71265.617 & 70698.523 & 1374.565 & 69146.555 & & $\begin{array}{l}1154.749 \\
\end{array}$ & 219.816 & 71265.617 & 1374.565 & & 1374.565 & & $\mathrm{H} 2 \mathrm{O}$ & \\
\hline S2 & & $<0.001$ & $<0.001$ & \begin{tabular}{|l|l|}
741.13 \\
\end{tabular} & & & $<0.001$ & 0.06 & $<0.001$ & 1673.231 & & 923.483 & & S2 & \\
\hline 56 & & 0.11 & 0.109 & 543.432 & & & 0.274 & 543.158 & 0.11 & 0.001 & & 0.001 & & 56 & \\
\hline 58 & & & $\begin{array}{l}0.774 \\
\end{array}$ & 388.677 & & & 0.57 & 1129.177 & 0.78 & 0.006 & & 0.006 & & 58 & \\
\hline $\mathrm{CO}$ & & 213897.828 & 212195.766 & 0.655 & 213897.172 & & $\begin{array}{r}0.655 \\
\end{array}$ & trace & 213897.828 & $\begin{array}{l}0.655 \\
\end{array}$ & & $\begin{array}{l}0.655 \\
\end{array}$ & & CO & \\
\hline $\mathrm{CO} 2$ & & 118728.914 & 117784.148 & 3618.024 & 115112.016 & & 3616.834 & 1.189 & 118728.914 & 3618.024 & & 2931.973 & & $\mathrm{CO} 2$ & \\
\hline $\mathrm{H} 2$ & & 11535.61 & $\begin{array}{l}11443.817 \\
\end{array}$ & $\begin{array}{l}0.24 \\
\end{array}$ & 11535.37 & & 0.24 & trace & 11535.61 & 0.24 & & $\begin{array}{l}0.24 \\
\end{array}$ & & $\mathrm{H} 2$ & \\
\hline $\mathrm{O2}$ & & & & & & 2545.084 & & & & & & & 2545.084 & $\mathrm{O} 2$ & \\
\hline N2 & & 44346.063 & 43993.184 & 8734.794 & 35611.336 & 8381.916 & 8734.721 & 0.073 & 44346.063 & 8734.794 & 8381.916 & 8734.794 & 8381.916 & N2 & \\
\hline COS & & 0.094 & 0.093 & $\begin{array}{l}0.094 \\
\end{array}$ & & & $\begin{array}{l}0.094 \\
\end{array}$ & $<0.001$ & 0.094 & $\begin{array}{l}0.094 \\
\end{array}$ & & 936.6 & & $\mathrm{CO}$ & \\
\hline $\mathrm{ZNO}$ & & & & & & & & & & & 4315.638 & & & $\mathrm{ZNO}$ & \\
\hline ZNS & & & & & & & & & 15452.001 & & 10284.438 & & & ZNS & \\
\hline AL2O3 & & & & & & & & & 56210.578 & & 56210.578 & & & AL2O3 & \\
\hline
\end{tabular}


DSRP-c 12/21/97 pg.2

\begin{tabular}{|c|c|c|c|c|c|c|c|c|c|c|c|c|c|c|c|}
\hline $\begin{array}{l}\text { Display ALLS } \\
\text { Units: } \\
\text { Format: SOLI }\end{array}$ & $\begin{array}{l}\text { TREAMS } \\
\text { From } \\
\text { DS To } \\
\text { Phas }\end{array}$ & \begin{tabular}{|l|} 
P-O2-N2 \\
PRESAIR \\
AIR-HX \\
VAPOR
\end{tabular} & $\begin{array}{l}\text { PCG-RECY } \\
\text { RECYCOMP } \\
\text { FEEDMIX } \\
\text { VAPOR }\end{array}$ & \begin{tabular}{|l|} 
RAW-CG \\
FEEDMIX \\
DESULF \\
VAPOR
\end{tabular} & \begin{tabular}{|l|} 
ROG \\
REGENSEP \\
AIR-HX \\
VAPOR
\end{tabular} & \begin{tabular}{|l|} 
ROG-COOL \\
AIR-HX \\
DSRPXO2 \\
VAPOR
\end{tabular} & \begin{tabular}{|l|} 
RXNPRD \\
DSRPMIX \\
PD-COOLR \\
VAPOR
\end{tabular} & \begin{tabular}{|l|} 
SLIPSTRM \\
VALVSLIP \\
VALVE2 \\
VAPOR \\
\end{tabular} & \begin{tabular}{|l|} 
SLPSTRM \\
VALVE2 \\
DSRPXO2 \\
VAPOR
\end{tabular} & \begin{tabular}{|l} 
SN-LIQ \\
SN-EQUIL \\
DSRPMIX \\
MISSING
\end{tabular} & \begin{tabular}{|l|} 
SN-VAP \\
SN-EQUIL \\
DSRPMIX \\
VAPOR
\end{tabular} & \begin{tabular}{|l|} 
STNDPIPE \\
ZNSCOOLR \\
STANDPIP \\
MISSING
\end{tabular} & \begin{tabular}{|l|} 
SULFUR \\
VAPORIZR \\
LIQUID
\end{tabular} & $\begin{array}{l}\text { Display ALLS } \\
\text { Units: } \\
\text { Format: SOLI }\end{array}$ & $\begin{array}{l}\text { TREAMS } \\
\text { From } \\
\text { DS To } \\
\text { Phas }\end{array}$ \\
\hline Temperature & [C] & 207.7 & 146.8 & 475.2 & 772.6 & 547.5 & 600 & 506.4 & 506.4 & & 600 & 506.4 & 140 & Temperature & \\
\hline Pressure & [PSI] & 279.3 & 275 & 275 & 274.1 & 272.1 & 269.1 & 274.9 & 272.1 & & 269.1 & 275 & 14.7 & Pressure & [PSI] \\
\hline Mass VFrac & & 1 & 1 & 1 & 1 & 1 & 1 & 1 & 1 & & 1 & 0 & & Mass VFrac & \\
\hline Mass SFrac & & 0 & 0 & 0 & 0 & 0 & 0 & 0 & 0 & & 0 & 1 & & Mass SFrac & \\
\hline$* * \star$ ALL PHAS & $\mathrm{ES}^{* * *}$ & & & & & & & & & & & & & *** ALL PHAS & $E S^{* * *}$ \\
\hline Mass Flow & {$[\mathrm{LB} / \mathrm{HR}]$} & $\begin{array}{l}0927 \\
\end{array}$ & 13553.382 & 460657.5 & 11778.925 & 11778.925 & 15437.757 & 3658.844 & 3658.844 & & $\begin{array}{l}15437.757 \\
\end{array}$ & 71662.578 & 1713.577 & Mass Flow & {$[\mathrm{LB} / \mathrm{HR}]$} \\
\hline Volume Flow & [CUFT/HR] & 12679.411 & 13452.904 & 1139190 & 26095.605 & 20645.352 & 30656.066 & 9447.959 & 9544.736 & & 30656.035 & 341.12 & 9.454 & Volume Flow & [CUFT/HR] \\
\hline Enthalpy & [BTU/HR] & 871552.063 & $-1.99 \mathrm{E}+07$ & $-1.09 \mathrm{E}+09$ & $-2.96 \mathrm{E}+06$ & $-4.18 \mathrm{E}+06$ & $-1.68 \mathrm{E}+07$ & $-8.63 \mathrm{E}+06$ & $-8.63 E+06$ & & $-1.68 \mathrm{E}+07$ & $-3.97 \mathrm{E}+08$ & $-1.30 \mathrm{E}+05$ & Enthalpy & {$[\mathrm{BTU} / \mathrm{HR}]$} \\
\hline Density & [LB/CUFT] & 0.862 & 1.007 & 0.404 & 0.451 & 0.571 & 0.504 & $\begin{array}{r}0.0067 \\
0.387\end{array}$ & $\begin{array}{r}0.0383 \\
\end{array}$ & & 0.504 & 210.08 & 181.246 & Density & [LB/CUFT] \\
\hline Mass Flow & {$[\mathrm{LB} / \mathrm{HR}]$} & & & & & & & & & & & & & \begin{tabular}{|l|l|} 
Mass Flow \\
\end{tabular} & {$[\mathrm{LB} / \mathrm{HR}]$} \\
\hline $\mathrm{O} 2 \mathrm{~S}$ & & & 15.704 & 15.704 & 3397.009 & 3397.009 & 15.747 & 0.125 & 0.125 & & 15.747 & & $<0.001$ & $\mathrm{O} 2 \mathrm{~S}$ & \\
\hline $\mathrm{H} 2 \mathrm{~S}$ & & & 20.368 & \begin{tabular}{|l|}
1822.044 \\
\end{tabular} & & & 20.399 & 0.118 & 0.118 & & 20.399 & & $<0.001$ & $\mathrm{H} 2 \mathrm{~S}$ & \\
\hline $\mathrm{H} 2 \mathrm{O}$ & & & 1163.806 & 70310.359 & & & 1374.565 & 567.087 & 567.087 & & 1374.565 & & \begin{tabular}{|l|}
41.723 \\
\end{tabular} & $\mathrm{H} 2 \mathrm{O}$ & \\
\hline S2 & & & $<0.001$ & $<0.001$ & & & $\begin{array}{l}741.13 \\
\end{array}$ & trace & trace & & $\begin{array}{l}741.13 \\
\end{array}$ & & 0.06 & S2 & \\
\hline S6 & & & 0.11 & \begin{tabular}{|l|} 
\\
\end{tabular} & & & 543.432 & 0.001 & 0.001 & & 543.432 & & 206.281 & S6 & \\
\hline S8 & & & 0.78 & $\begin{array}{l}0.78 \\
\end{array}$ & & & 388.677 & 0.006 & 0.006 & & 388.677 & & 1465.512 & 58 & \\
\hline CO & & & 0.655 & 213897.828 & & & 0.655 & 1702.064 & 1702.064 & & 0.655 & & & CO & \\
\hline $\mathrm{CO} 2$ & & & 3616.9 & 118728.914 & & & \begin{tabular}{|l|}
3618.024 \\
\end{tabular} & 944.77 & 944.77 & & 3618.024 & & 0.001 & \begin{tabular}{|l|}
$\mathrm{CO} 2$ \\
\end{tabular} & \\
\hline $\mathrm{H} 2$ & & & 0.24 & 11535.61 & & & 0.24 & 91.793 & 91.793 & & 0.24 & & trace & $\mathrm{H} 2$ & \\
\hline $\mathrm{O} 2$ & & 2545.084 & & & & & & & & & & & & O2 & \\
\hline N2 & & 8381.916 & 8734.726 & 44346.063 & 8381.916 & 8381.916 & 8734.794 & 352.878 & 352.878 & & 8734.794 & & trace & N2 & \\
\hline $\cos$ & & & 0.094 & 0.094 & & & 0.094 & 0.001 & 0.001 & & 0.094 & & trace & $\cos$ & \\
\hline ZNO & & & & & & & & & & & & & & \begin{tabular}{|l|} 
ZNOO \\
\end{tabular} & \\
\hline ZNS & & & & & & & & & & & & 15452.001 & & ZNS & \\
\hline AL2O3 & & & & & & & & & & & & 56210.578 & & \begin{tabular}{|l} 
AL2O3 \\
\end{tabular} & \\
\hline
\end{tabular}


DSRP-c 12/21/97 pg.3

\begin{tabular}{|c|c|c|c|c|c|c|c|c|c|c|c|c|c|}
\hline $\begin{array}{l}\text { Display ALLS } \\
\text { Units: } \\
\text { Format: SOLI } \\
\\
\text { Temperature }\end{array}$ & $\begin{array}{l}\text { TREAMS } \\
\text { From } \\
\text { DS To } \\
\text { Phas } \\
{[C]} \\
\end{array}$ & \begin{tabular}{|l|} 
TAILGAS \\
COND-II \\
VALVE \\
VAPOR \\
\end{tabular} & \begin{tabular}{|l} 
TAILGAS2 \\
VALVE \\
RECYCOMP \\
VAPOR \\
$\quad 139.9$ \\
\end{tabular} & \begin{tabular}{|l|} 
TO-VAP \\
COND-II \\
VAPORIZR \\
LIQUID \\
\\
\end{tabular} & \begin{tabular}{|l} 
VENT \\
VAPORIZR \\
VAPOR \\
\end{tabular} & \begin{tabular}{|l} 
XO2LIQ \\
DSRPXO2 \\
DSRP \\
MISSING \\
\end{tabular} & \begin{tabular}{|l|} 
XO2VAP \\
DSRPXO2 \\
DSRP \\
VAPOR \\
\end{tabular} & \begin{tabular}{|l} 
ZNO \\
REGENSEP \\
DESULF \\
MISSING \\
$\quad 772.6$ \\
\end{tabular} & \begin{tabular}{|l} 
ZNS \\
DESULSEP \\
ZNSCOOLR \\
MISSING \\
$\quad 506.4$ \\
\end{tabular} & $\begin{array}{l}\text { ZNS-RECY } \\
\text { STANDPIP } \\
\text { DESULF } \\
\text { MISSING }\end{array}$ & \begin{tabular}{|c|} 
ZNS2RGEN \\
STANDPIP \\
REGEN \\
MISSING \\
506.4 \\
\end{tabular} & $\begin{array}{l}\text { Display ALLS } \\
\text { Units: } \\
\text { Format: SOLI } \\
\text { Temperature }\end{array}$ & $\begin{array}{l}\text { TREAMS } \\
\text { From } \\
\text { DS To } \\
\text { Phas } \\
\text { [C] } \\
\end{array}$ \\
\hline Pressure & {$[\mathrm{PSI}]$} & $\begin{array}{r}140.1 \\
\end{array}$ & 262.5 & \begin{tabular}{|r|}
265.1 \\
\end{tabular} & $\begin{array}{r}140 \\
14.7\end{array}$ & & \begin{tabular}{|r|}
269.1 \\
\end{tabular} & 274.1 & 274.9 & & \begin{tabular}{|r|} 
\\
\end{tabular} & \begin{tabular}{|l} 
Pressure \\
\end{tabular} & {$[\mathrm{PSI}]$} \\
\hline Mass VFrac & & 1 & 1 & 0 & 1 & & 1 & 0 & 0 & & 0 & Mass VFrac & \\
\hline Mass SFrac & & 0 & 0 & 0 & 0 & & 0 & 1 & 1 & & 1 & Mass SFrac & \\
\hline$* * \star$ ALL PHAS & $\mathrm{ES}^{* * *}$ & & & & & & & & & & & ${ }^{* * *}$ ALL PHAS & $\mathrm{ES}^{* * *}$ \\
\hline Mass Flow & {$[\mathrm{LB} / \mathrm{HR}]$} & 13553.382 & 13553.382 & 1884.374 & 170.798 & 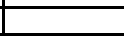 & \begin{tabular}{l|l}
15437.86 \\
\end{tabular} & 70810.656 & 71662.578 & 3 & 71662.578 & Mass Flow & {$[\mathrm{LB} / \mathrm{HR}]$} \\
\hline Volume Flow & [CUFT/HR] & 13719.107 & 13854.065 & 13.12 & 5077.429 & & 33024.156 & 341.12 & 341.12 & & 341.12 & Volume Flow & [CUFT/HR] \\
\hline Enthalpy & {$[\mathrm{BTU} / \mathrm{HR}]$} & $-2.00 \mathrm{E}+07$ & $-2.00 \mathrm{E}+07$ & $-1.25 \mathrm{E}+06$ & $-9.65 \mathrm{E}+05$ & & $\begin{array}{l}-1.25 \mathrm{E}+07 \\
\end{array}$ & $-3.91 \mathrm{E}+08$ & $-3.97 \mathrm{E}+08$ & $0.00 \mathrm{E}+00$ & $-3.97 \mathrm{E}+08$ & \begin{tabular}{|l|} 
Enthalpy \\
\end{tabular} & {$[\mathrm{BTU} / \mathrm{HR}]$} \\
\hline Density & [LB/CUFT] & 0.988 & 0.978 & 143.629 & $\begin{array}{r}.0034 \\
\end{array}$ & & 0.467 & 207.583 & 210.08 & & 210.08 & \begin{tabular}{|l|} 
Density \\
\end{tabular} & [LB/CUFT] \\
\hline Mass Flow & {$[\mathrm{LB} / \mathrm{HR}]$} & & & & & & & & & & & Mass Flow & {$[\mathrm{LB} / \mathrm{HR}]$} \\
\hline $\mathrm{O} 2 \mathrm{~S}$ & & 15.704 & 15.704 & 0.043 & 0.042 & & 3397.134 & & & & & O2S & \\
\hline $\mathrm{H} 2 \mathrm{~S}$ & & 20.368 & 20.368 & 0.031 & 0.031 & & 0.118 & & & & & $\mathrm{H} 2 \mathrm{~S}$ & \\
\hline $\mathrm{H} 2 \mathrm{O}$ & & \begin{tabular}{|r|}
1163.806 \\
\end{tabular} & 1163.806 & 210.759 & \begin{tabular}{|l|}
169.036 \\
\end{tabular} & & 315.4 & & & & & $\mathrm{H} 2 \mathrm{O}$ & \\
\hline S2 & & $\begin{array}{l}<0.001 \\
\end{array}$ & $<0.001$ & 0.06 & $<0.001$ & & trace & & & & & S2 & \\
\hline S6 & & $\begin{array}{l}0.11 \\
\end{array}$ & 0.11 & 206.342 & 0.061 & & 0.001 & & & & & S6 & \\
\hline S8 & & 0.78 & 0.78 & \begin{tabular}{|l|l|}
1465.947 \\
\end{tabular} & 0.435 & & 0.006 & & & & & \begin{tabular}{|l|}
58 \\
\end{tabular} & \\
\hline $\mathrm{CO}$ & & 0.655 & 0.655 & trace & trace & & 1310.713 & & & & & \begin{tabular}{|l|}
$\mathrm{CO}$ \\
\end{tabular} & \\
\hline $\mathrm{CO} 2$ & & 3616.9 & 3616.9 & 1.124 & 1.123 & & 1559.735 & & & & & \begin{tabular}{|l|}
$\mathrm{CO} 2$ \\
\end{tabular} & \\
\hline $\mathrm{H} 2$ & & 0.24 & 0.24 & trace & trace & & 119.958 & & & & & $\mathrm{H} 2$ & \\
\hline $\mathrm{O} 2$ & & & & & & & & & & & & O2 & \\
\hline N2 & & 8734.726 & 8734.726 & 0.069 & 0.069 & & 8734.794 & & & & & N2 & \\
\hline $\cos$ & & 0.094 & 0.094 & $<0.001$ & $<0.001$ & & 0.001 & & & & & $\cos$ & \\
\hline ZNO & & & & & & & & 4315.638 & & & & \begin{tabular}{|l|}
$\mathrm{ZNO}$ \\
\end{tabular} & \\
\hline ZNS & & & & & & & & 10284.438 & 15452.001 & & 15452.001 & ZNS & \\
\hline AL2O3 & & & & & & & & 56210.578 & 56210.578 & & 56210.578 & \begin{tabular}{|l|l|}
$\mathrm{AL} 2 \mathrm{O} 3$ \\
\end{tabular} & \\
\hline
\end{tabular}




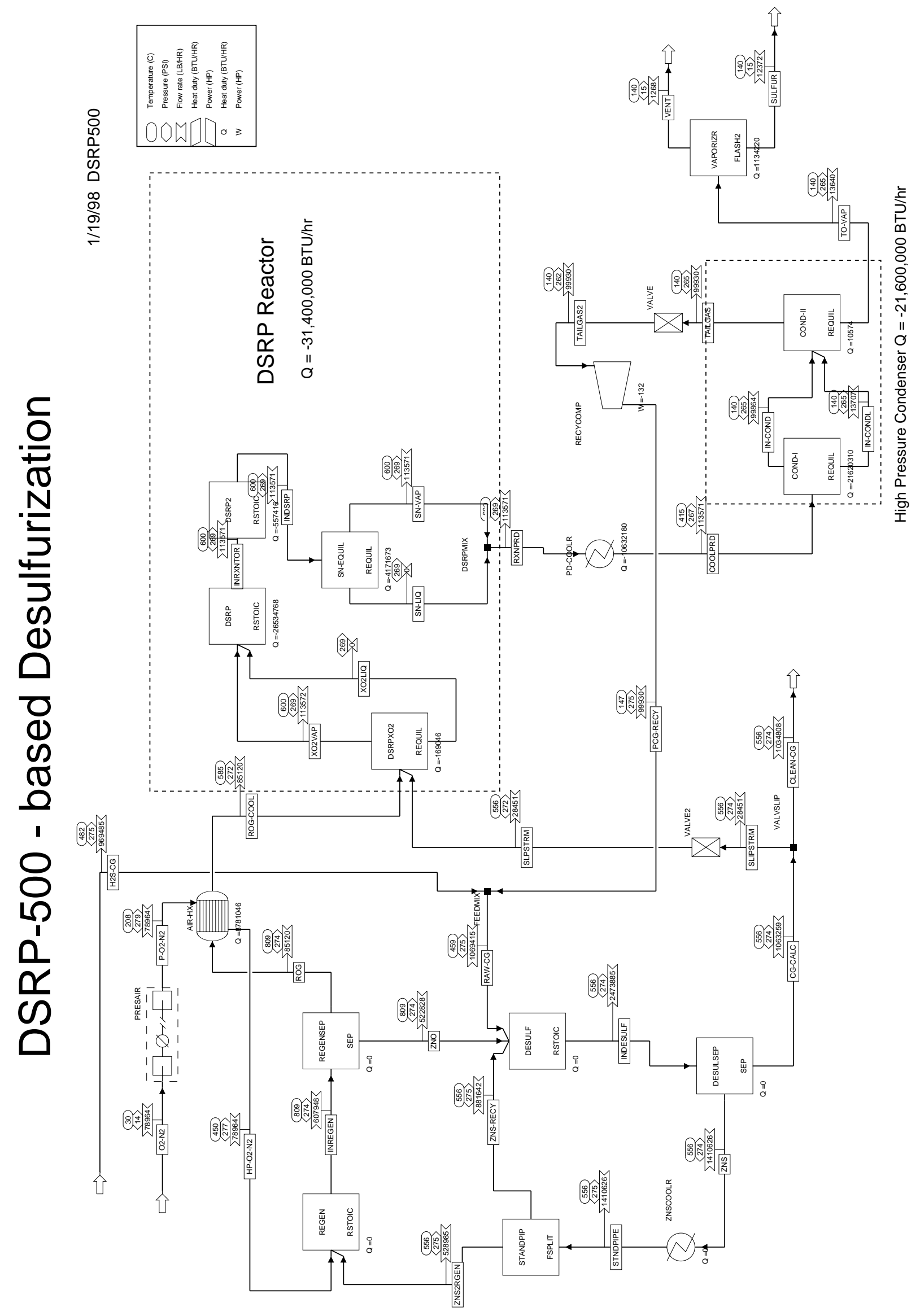




\section{DSRP-500 1/19/98 pg.1}

\begin{tabular}{|c|c|c|c|c|c|c|c|c|c|c|c|c|c|c|c|}
\hline $\begin{array}{l}\text { Display ALLS } \\
\text { Units: } \\
\text { Format: SOLI }\end{array}$ & $\begin{array}{l}\text { TREAMS } \\
\text { From } \\
\text { DS To } \\
\text { Phas }\end{array}$ & \begin{tabular}{|l|} 
CG-CALC \\
DESULSEP \\
VALVSLIP \\
VAPOR \\
\end{tabular} & $\begin{array}{l}\text { CLEAN-CG } \\
\text { VALVSLIP } \\
\text { VAPOR }\end{array}$ & \begin{tabular}{|l|} 
COOLPRD \\
PD-COOLR \\
CONDD-I \\
VAPOR \\
\end{tabular} & \begin{tabular}{|l|} 
H2S-CG \\
FEEDMIX \\
VAPOR
\end{tabular} & \begin{tabular}{|l|} 
HP-O2-N2 \\
AlR-HX \\
REGEN \\
VAPOR
\end{tabular} & \begin{tabular}{|l|} 
IN-COND \\
COND-II \\
COND-II \\
VAPOR
\end{tabular} & \begin{tabular}{|l|} 
IN-CONDL \\
COND-I \\
CONDIII \\
LIQUID \\
\end{tabular} & \begin{tabular}{|l|} 
INDESULF \\
DESULF \\
DESULSEP \\
VAPOR
\end{tabular} & \begin{tabular}{|l|} 
INDSRPP \\
DSRP2 \\
SN-EQUIL \\
VAPOR \\
\end{tabular} & \begin{tabular}{|l|} 
INREGEN \\
REGEN \\
REGENSEP \\
VAPOR
\end{tabular} & \begin{tabular}{|l|} 
INRXNTOR \\
DSRP \\
DSRP2 \\
VAPOR \\
\end{tabular} & \begin{tabular}{|l} 
O2-N2 \\
PRESAIR \\
VAPOR
\end{tabular} & \begin{tabular}{|l} 
Display ALLS \\
Units: \\
Format: SOLI
\end{tabular} & $\begin{array}{l}\text { TREAMS } \\
\text { From } \\
\text { DS To } \\
\text { Phas }\end{array}$ \\
\hline $\begin{array}{l}\text { Temperature } \\
\text { Pressure }\end{array}$ & $\frac{[\mathrm{C}]}{[\mathrm{PSI}]}$ & \begin{tabular}{|l|}
556.1 \\
274.4
\end{tabular} & \begin{tabular}{|l}
556.1 \\
274.4
\end{tabular} & \begin{tabular}{|r}
415 \\
266.6
\end{tabular} & \begin{tabular}{|r|}
482.2 \\
275 \\
\end{tabular} & $\begin{array}{r}450 \\
276.9\end{array}$ & $\begin{array}{r}140 \\
264.6\end{array}$ & \begin{tabular}{|r|}
140 \\
264.6
\end{tabular} & \begin{tabular}{|r|}
556.1 \\
274.4
\end{tabular} & \begin{tabular}{|r|}
600 \\
268.6 \\
\end{tabular} & \begin{tabular}{|r|}
808.9 \\
273.6
\end{tabular} & $\begin{array}{r}600 \\
268.6\end{array}$ & \begin{tabular}{|r}
30 \\
13.7
\end{tabular} & Temperature & $\frac{[\mathrm{C}]}{[\mathrm{PSI}]}$ \\
\hline Mass VFrac & & 1 & & 1 & 1 & 1 & 1 & $\frac{204.0}{0}$ & 0.43 & $\frac{200.09}{1}$ & 0.14 & $\frac{260.0}{1}$ & 13.1 & \begin{tabular}{|l} 
Pressure \\
Mass VFrac
\end{tabular} & [PSI] \\
\hline Mass SFrac & & 0 & 0 & 0 & 0 & 0 & 0 & 0 & 0.57 & 0 & 0.86 & & & Mass SFrac & \\
\hline${ }^{* \star \star}$ ALL PHAS & $E S^{* \star *}$ & & & & & & & & & & & & & ${ }^{* \star \star}$ ALL PHAS & $E S^{\star \star \star}$ \\
\hline Mass Flow & {$[\mathrm{LB} / \mathrm{HR}]$} & 1063260 & 1034810 & 113570.906 & 969485 & 78963.703 & 99863.633 & 13707.267 & $2.47 \mathrm{E}+06$ & 113570.898 & 607948.188 & 113571.234 & 78963.703 & Mass Flow & [LB/HR] \\
\hline Volume Flow & [CUFT/HR] & $2.87 \mathrm{E}+06$ & $2.80 \mathrm{E}+06$ & 179490.672 & $2.43 E+06$ & 138997.172 & 101285.656 & 100.854 & $2.88 \mathrm{E}+06$ & 230923.609 & 197974.375 & 229302.5 & 1169520 & Volume Flow & [CUFT/HR] \\
\hline Enthalpy & {$[\mathrm{BTU} / \mathrm{HR}]$} & $-2.41 E+09$ & $-2.35 \mathrm{E}+09$ & $-1.35 \mathrm{E}+08$ & $\begin{array}{r}-2.30 \mathrm{E}+09 \\
\end{array}$ & $1.51 \mathrm{E}+07$ & $-1.47 \mathrm{E}+08$ & $-9.63 E+06$ & $-1.02 \mathrm{E}+10$ & $-1.20 \mathrm{E}+08$ & $-2.90 \mathrm{E}+09$ & $-1.20 \mathrm{E}+08$ & 163338.5 & Enthalpy & {$[\mathrm{BTU} / \mathrm{HR}]$} \\
\hline Density & [LB/CUFT] & 0.37 & 0.37 & $\begin{array}{l}0.633 \\
\end{array}$ & 0.399 & 0.568 & 0.986 & 135.912 & 0.859 & $\begin{array}{l}0.492 \\
\end{array}$ & 3.071 & 0.495 & 0.068 & & [LB/CUFT] \\
\hline Mass Flow & [LB/HR] & & & & & & & & & & & & & Mass Flow & {$[\mathrm{LB} / \mathrm{HR}]$} \\
\hline $\mathrm{O} 2 \mathrm{~S}$ & & 134.563 & 130.963 & 134.922 & & & $\begin{array}{ll}134.543 \\
\end{array}$ & 0.379 & 134.563 & 134.922 & 24548.4 & 3689.37 & & O2S & \\
\hline $\mathrm{H} 2 \mathrm{~S}$ & & 298.899 & 290.901 & 156.105 & 13202.553 & & 155.855 & 0.25 & 298.899 & 156.105 & & 156.105 & & $\mathrm{H} 2 \mathrm{~S}$ & \\
\hline $\mathrm{H} 2 \mathrm{O}$ & & 164058.219 & 159668.297 & 10220.242 & \begin{tabular}{|l|l|}
148491.516 \\
\end{tabular} & & 8597.656 & 1622.586 & 164058.219 & 10220.242 & & 10220.242 & & $\mathrm{H} 2 \mathrm{O}$ & \\
\hline S2 & & $<0.001$ & $<0.001$ & 5421.442 & & & $<0.001$ & 0.438 & $<0.001$ & 12080.898 & & 6743.967 & & $\mathrm{S2}$ & \\
\hline 56 & & 0.803 & 0.782 & 3898.438 & & & 1.989 & 3896.449 & \begin{tabular}{|l|}
0.803 \\
\end{tabular} & 0.021 & & 0.021 & & 56 & \\
\hline 58 & & 5.689 & 5.537 & 2761.193 & & & 4.175 & \begin{tabular}{|l|}
8178.022 \\
\end{tabular} & 5.689 & 0.152 & & 0.152 & & S8 & \\
\hline $\mathrm{CO}$ & & 459346.656 & 447055.344 & 4.665 & 459341.969 & & 4.665 & $<0.001$ & 459346.656 & 4.665 & & 4.665 & & $\mathrm{cO}$ & \\
\hline $\mathrm{CO} 2$ & & 273825.563 & 266498.469 & 26631.824 & 247201.875 & & 26623.211 & 8.614 & 273825.563 & 26631.824 & & 21748.314 & & $\mathrm{CO} 2$ & \\
\hline $\mathrm{H} 2$ & & 24773.842 & 24110.938 & 1.752 & 24772.09 & & 1.752 & 0.001 & 24773.842 & 1.752 & & 1.752 & & $\mathrm{H} 2$ & \\
\hline $\mathrm{O} 2$ & & & & & & 18391.988 & & & & & & & 18391.988 & $\mathrm{O} 2$ & \\
\hline N2 & & 140814.141 & 137046.203 & 64339.652 & 76474.984 & 60571.711 & 64339.125 & 0.528 & 140814.141 & 64339.652 & 60571.711 & 64339.652 & 60571.711 & & \\
\hline $\cos$ & & 0.666 & 0.649 & $\begin{array}{l}0.667 \\
\end{array}$ & & & 0.666 & $<0.001$ & 0.666 & 0.667 & & 6666.993 & & $\cos$ & \\
\hline $\mathrm{ZNO}$ & & & & & & & & & & & 31186.855 & & & ZNO & \\
\hline ZNS & & & & & & & & & 304172 & & \begin{tabular}{|l|}
76721.18 \\
\end{tabular} & & & ZNS & \\
\hline AL2O3 & & & & & & & & & 1106450 & & 414920.063 & & & AL2O3 & \\
\hline
\end{tabular}


DSRP-500 1/19/98 pg.2

\begin{tabular}{|c|c|c|c|c|c|c|c|c|c|c|c|c|c|c|c|}
\hline $\begin{array}{l}\text { Display ALLS } \\
\text { Units: } \\
\text { Format: SOLI }\end{array}$ & $\begin{array}{l}\text { TREAMS } \\
\text { From } \\
\text { DS To } \\
\text { Phas }\end{array}$ & \begin{tabular}{|l} 
P-O2-N2 \\
PRESAIR \\
AIR-HX \\
VAPOR
\end{tabular} & $\begin{array}{l}\text { PCG-RECY } \\
\text { RECYCOMP } \\
\text { FEEDMIX } \\
\text { VAPOR }\end{array}$ & \begin{tabular}{|l|} 
RAW-CG \\
FEEDMIX \\
DESULF \\
VAPOR
\end{tabular} & \begin{tabular}{|l|} 
ROG \\
REGENSEP \\
AlR-HX \\
VAPOR
\end{tabular} & \begin{tabular}{|l|} 
ROG-COOL \\
AIR-HX \\
DSRPXO2 \\
VAPOR
\end{tabular} & \begin{tabular}{|l|} 
RXNPRD \\
DSRPMIX \\
PD-COOLR \\
VAPOR
\end{tabular} & \begin{tabular}{|l|} 
SLIPSTRM \\
VALVSLIP \\
VALVE2 \\
VAPOR
\end{tabular} & \begin{tabular}{|l|} 
SLPSTRM \\
VALVE2 \\
DSRPXO2 \\
VAPOR \\
\end{tabular} & \begin{tabular}{|l} 
SN-LIQ \\
SN-EQUIL \\
DSRPMIX \\
MISSING
\end{tabular} & \begin{tabular}{|l|} 
SN-VAP \\
SN-EQUIL \\
DSRPMIX \\
VAPOR
\end{tabular} & \begin{tabular}{|l|} 
STNDPIPE \\
ZNSCOOLR \\
STANDPIP \\
MISSING
\end{tabular} & \begin{tabular}{|l|} 
SULFUR \\
VAPORIZR \\
LIQUID
\end{tabular} & $\begin{array}{l}\text { Display ALLS } \\
\text { Units: } \\
\text { Format: SOLI }\end{array}$ & $\begin{array}{l}\text { TREAMS } \\
\text { From } \\
\text { DS To } \\
\text { Phas }\end{array}$ \\
\hline Temperature & [C] & 207.6 & 147.1 & 459.3 & \begin{tabular}{|ll} 
& 808.9 \\
\end{tabular} & 585.1 & 600 & 556.1 & 556.1 & & 600 & 556.1 & 140 & Temperature & \\
\hline Pressure & [PSI] & 278.9 & 275 & 275 & 273.6 & 271.6 & 268.6 & 274.4 & 271.6 & & 268.6 & 275 & 14.7 & Pressure & [PSI] \\
\hline Mass VFrac & & 1 & 1 & 1 & 1 & 1 & 1 & 1 & 1 & & 1 & 0 & & Mass VFrac & \\
\hline Mass SFrac & & 0 & 0 & 0 & 0 & 0 & 0 & 0 & 0 & & 0 & 1 & & Mass SFrac & \\
\hline$* * \star$ ALL PHAS & $\mathrm{ES}^{* * *}$ & & & & & & & & & & & & & *** ALL PHAS & $E S^{* * *}$ \\
\hline Mass Flow & {$[\mathrm{LB} / \mathrm{HR}]$} & 78963.703 & 99930.422 & 1069420 & \begin{tabular}{|l|}
85120.109 \\
\end{tabular} & 85120.109 & 113570.906 & 28450.951 & 28450.951 & 0 & 113570.906 & 1410630 & 12372.203 & Mass Flow & {$[\mathrm{LB} / \mathrm{HR}]$} \\
\hline Volume Flow & [CUFT/HR] & 91749.711 & 99302.75 & $2.53 \mathrm{E}+06$ & 195456.375 & 156297.594 & 226467.672 & 76921.539 & 77711.063 & & 226467.438 & 6714.697 & 68.27 & Volume Flow & [CUFT/HR] \\
\hline Enthalpy & [BTU/HR] & $6.30 \mathrm{E}+06$ & $-1.47 \mathrm{E}+08$ & $-2.44 \mathrm{E}+09$ & $-2.00 \mathrm{E}+07$ & $-2.88 \mathrm{E}+07$ & $-1.25 \mathrm{E}+08$ & $-6.45 \mathrm{E}+07$ & -64473000 & $0.00 \mathrm{E}+00$ & $-1.25 \mathrm{E}+08$ & $-7.77 \mathrm{E}+09$ & $-9.42 \mathrm{E}+05$ & Enthalpy & {$[\mathrm{BTU} / \mathrm{HR}]$} \\
\hline Density & [LB/CUFT] & 0.861 & 1.006 & $\frac{0.422}{0.442}$ & $\begin{array}{r}0.435 \\
\end{array}$ & $\begin{array}{r}0.545 \\
\end{array}$ & 0.501 & $\begin{array}{r}0.40 \mathrm{~L} \\
0.37\end{array}$ & 0.366 & & 0.501 & 210.08 & $\begin{array}{l}.4225 \\
181.225\end{array}$ & Density & [LB/CUFT] \\
\hline Mass Flow & {$[\mathrm{LB} / \mathrm{HR}]$} & & & & & & & & & & & & & \begin{tabular}{|l|l|} 
Mass Flow \\
\end{tabular} & {$[\mathrm{LB} / \mathrm{HR}]$} \\
\hline $\mathrm{O} 2 \mathrm{~S}$ & & & 134.563 & 134.563 & 24548.4 & 24548.4 & 134.922 & 3.601 & 3.601 & & 134.922 & & 0.002 & O2S & \\
\hline $\mathrm{H} 2 \mathrm{~S}$ & & & 155.868 & 13358.421 & & & 156.105 & 7.998 & 7.998 & & 156.105 & & 0.001 & $\mathrm{H} 2 \mathrm{~S}$ & \\
\hline $\mathrm{H} 2 \mathrm{O}$ & & & 8663.586 & 157155.109 & & & 10220.242 & 4389.911 & 4389.911 & & 10220.242 & & 301.303 & $\mathrm{H} 2 \mathrm{O}$ & \\
\hline S2 & & & $<0.001$ & $<0.001$ & & & 5421.442 & trace & trace & & $\begin{array}{l}5421.442 \\
\end{array}$ & & $\begin{array}{l}0.437 \\
\end{array}$ & S2 & \\
\hline S6 & & & \begin{tabular}{|c}
0.803 \\
\end{tabular} & 0.803 & & & 3898.438 & 0.021 & 0.021 & & 3898.438 & & 1493.655 & 56 & \\
\hline S8 & & & 5.689 & $\begin{array}{r}0.0089 \\
5.689\end{array}$ & & & 2761.193 & 0.152 & $\begin{array}{l}0.152 \\
0.152\end{array}$ & & 2761.193 & & 10576.002 & 58 & \\
\hline CO & & & 4.665 & 459346.656 & & & 4.665 & 12291.313 & 12291.313 & & 4.665 & & trace & CO & \\
\hline $\mathrm{CO} 2$ & & & 26623.678 & 273825.563 & & & 26631.824 & 7327.093 & 7327.093 & & 26631.824 & & 0.005 & $\mathrm{CO} 2$ & \\
\hline $\mathrm{H} 2$ & & & 1.752 & 24773.842 & & & 1.752 & 662.905 & 662.905 & & 1.752 & & trace & $\mathrm{H} 2$ & \\
\hline $\mathrm{O} 2$ & & 18391.988 & & & & & & & & & & & & O2 & \\
\hline N2 & & 60571.711 & 64339.152 & 140814.141 & 60571.711 & 60571.711 & 64339.652 & 3767.94 & 3767.94 & & 64339.652 & & trace & N2 & \\
\hline $\cos$ & & & 0.666 & 0.666 & & & 0.667 & 0.018 & 0.018 & & 0.667 & & trace & $\cos$ & \\
\hline ZNO & & & & & & & & & & & & & & \begin{tabular}{|l|} 
ZNO \\
\end{tabular} & \\
\hline ZNS & & & & & & & & & & & & 304172 & & ZNS & \\
\hline AL2O3 & & & & & & & & & & & & 1106450 & & AL2O3 & \\
\hline
\end{tabular}


DSRP-500 1/19/98 pg.3

\begin{tabular}{|c|c|c|c|c|c|c|c|c|c|c|c|c|c|c|c|}
\hline \begin{tabular}{|l|} 
Display ALLS \\
Units: \\
Format: SOLI \\
\end{tabular} & $\begin{array}{l}\text { TREAMS } \\
\text { From } \\
\text { DS To } \\
\text { Phas }\end{array}$ & \begin{tabular}{|l|} 
P-O2-N2 \\
PRESAIR \\
AIR-HX \\
VAPOR \\
\end{tabular} & \begin{tabular}{|l|} 
PCG-RECY \\
RECYCOMP \\
FEEDMIX \\
VAPOR
\end{tabular} & \begin{tabular}{|l|} 
RAW-CG \\
FEEDMIX \\
DESULF \\
VAPOR \\
\end{tabular} & \begin{tabular}{|l|} 
ROG \\
REGENSEP \\
AIR-HX \\
VAPOR \\
\end{tabular} & $\begin{array}{l}\text { ROG-COOL } \\
\text { AIR-HX } \\
\text { DSRPXO2 } \\
\text { VAPOR }\end{array}$ & \begin{tabular}{|l|} 
RXNPRD \\
DSRPMIX \\
PD-COOLR \\
VAPOR \\
\end{tabular} & \begin{tabular}{|l|} 
SLIPSTRM \\
VALVSLIP \\
VALVE2 \\
VAPOR
\end{tabular} & \begin{tabular}{|l|} 
SLPSTRM \\
VALVE2 \\
DSRPXO2 \\
VAPOR \\
\end{tabular} & $\begin{array}{l}\text { SN-LIQ } \\
\text { SN-EQUIL } \\
\text { DSRPMIX } \\
\text { MISSING }\end{array}$ & \begin{tabular}{|l|} 
SN-VAP \\
SN-EQUIL \\
DSRPMIX \\
VAPOR
\end{tabular} & \begin{tabular}{|l|} 
STNDPIPE \\
ZNSCOOLR \\
STANDPIP \\
MISSING
\end{tabular} & $\begin{array}{l}\text { SULFUR } \\
\text { VAPORIZR } \\
\text { LIQUID }\end{array}$ & $\begin{array}{l}\text { Display ALLS } \\
\text { Units: } \\
\text { Format: SOLI } \\
\end{array}$ & $\begin{array}{l}\text { TREAMS } \\
\text { From } \\
\text { DS To } \\
\text { Phas }\end{array}$ \\
\hline $\begin{array}{l}\text { Temperature } \\
\text { Pressure }\end{array}$ & $\frac{[\mathrm{C}]}{[\mathrm{PSI}]}$ & \begin{tabular}{|r|}
207.6 \\
278.9
\end{tabular} & \begin{tabular}{|r}
147.1 \\
275
\end{tabular} & \begin{tabular}{|r|}
459.3 \\
275 \\
\end{tabular} & \begin{tabular}{|r|}
808.9 \\
273.6
\end{tabular} & $\begin{array}{r}585.1 \\
271.6\end{array}$ & \begin{tabular}{|r}
600 \\
268.6 \\
\end{tabular} & \begin{tabular}{|l|}
556.1 \\
274.4
\end{tabular} & \begin{tabular}{r|}
556.1 \\
271.6 \\
\end{tabular} & & \begin{tabular}{|r|}
600 \\
268.6
\end{tabular} & & \begin{tabular}{|r}
140 \\
14.7
\end{tabular} & \begin{tabular}{|l} 
Temperature \\
Pressure
\end{tabular} & $\frac{[\mathrm{C}]}{[\mathrm{PSI}]}$ \\
\hline Mass VFrac & & 1 & & 1 & 1 & 1 & 1 & 1 & $\frac{271.6}{1}$ & & $\begin{array}{r}200.0 \\
1\end{array}$ & 0 & $\frac{14.1}{0}$ & \begin{tabular}{|l} 
Pressure \\
Mass VFrac
\end{tabular} & [PSI] \\
\hline Mass SFrac & & 0 & 0 & 0 & 0 & 0 & 0 & 0 & 0 & & 0 & & & Mass SFrac & \\
\hline$\overline{\star \star *}^{\star \star *}$ ALL PHAS & $E S^{* * *}$ & & & & & & & & & & & & & ${ }^{* \star \star}$ ALL PHAS & $E S^{* \star *}$ \\
\hline Mass Flow & {$[\mathrm{LB} / \mathrm{HR}]$} & 78963.703 & 99930.422 & 1069420 & 85120.109 & 85120.109 & 113570.906 & 28450.951 & 28450.951 & 0 & 113570.906 & 1410630 & 12372.203 & Mass Flow & {$[\mathrm{LB} / \mathrm{HR}]$} \\
\hline Volume Flow & [CUFT/HR] & 91749.711 & 99302.75 & $2.53 \mathrm{E}+06$ & 195456.375 & 156297.594 & 226467.672 & 76921.539 & 77711.063 & & 226467.438 & 6714.697 & 68.27 & Volume Flow & [CUFT/HR] \\
\hline Enthalpy & {$[\mathrm{BTU} / \mathrm{HR}]$} & $6.30 \mathrm{E}+06$ & $-1.47 \mathrm{E}+08$ & $\begin{array}{l}-2.44 E+09 \\
\end{array}$ & $-2.00 \mathrm{E}+07$ & $-2.88 \mathrm{E}+07$ & $-1.25 \mathrm{E}+08$ & $-6.45 E+07$ & -64473000 & $0.00 \mathrm{E}+00$ & $-1.25 \mathrm{E}+08$ & $-7.77 E+09$ & $-9.42 \mathrm{E}+05$ & Enthalpy & {$[\mathrm{BTU} / \mathrm{HR}]$} \\
\hline Density & [LB/CUFT] & 0.861 & 1.006 & 0.422 & 0.435 & 0.545 & 0.501 & 0.37 & 0.366 & & 0.501 & 210.08 & 181.225 & Density & [LB/CUFT] \\
\hline Mass Flow & [LB/HR] & & & & & & & & & & & & & Mass Flow & {$[\mathrm{LB} / \mathrm{HR}]$} \\
\hline $\mathrm{O} 2 \mathrm{~S}$ & & & 134.563 & 134.563 & 24548.4 & 24548.4 & 134.922 & 3.601 & 3.601 & & 134.922 & & 0.002 & $\mathrm{O} 2 \mathrm{~S}$ & \\
\hline $\mathrm{H} 2 \mathrm{~S}$ & & & 155.868 & 13358.421 & & & 156.105 & 7.998 & 7.998 & & \begin{tabular}{|l|}
156.105 \\
\end{tabular} & & 0.001 & $\mathrm{H} 2 \mathrm{~S}$ & \\
\hline $\mathrm{H} 2 \mathrm{O}$ & & & 8663.586 & $\begin{array}{r}157155.109 \\
\end{array}$ & & & 10220.242 & 4389.911 & 4389.911 & & 10220.242 & & 301.303 & $\mathrm{H} 2 \mathrm{O}$ & \\
\hline S2 & & & $<0.001$ & $<0.001$ & & & 5421.442 & trace & trace & & 5421.442 & & 0.437 & 52 & \\
\hline 56 & & & 0.803 & 0.803 & & & 3898.438 & 0.021 & 0.021 & & 3898.438 & & 1493.655 & 56 & \\
\hline S8 & & & 5.689 & 5.689 & & & 2761.193 & 0.152 & 0.152 & & 2761.193 & & 10576.802 & 58 & \\
\hline $\mathrm{CO}$ & & & 4.665 & 459346.656 & & & 4.665 & 12291.313 & 12291.313 & & 4.665 & & trace & $\mathrm{CO}$ & \\
\hline $\mathrm{CO} 2$ & & & 26623.678 & 273825.563 & & & 26631.824 & 7327.093 & 7327.093 & & 26631.824 & & 0.005 & $\mathrm{CO} 2$ & \\
\hline $\mathrm{H} 2$ & & & 1.752 & 24773.842 & & & 1.752 & 662.905 & 662.905 & & 1.752 & & trace & $\mathrm{H} 2$ & \\
\hline$\overline{\mathrm{O} 2}$ & & \begin{tabular}{|c|}
18391.988 \\
\end{tabular} & & & & & & & & & & & & $\mathrm{O} 2$ & \\
\hline N2 & & 60571.711 & 64339.152 & 140814.141 & 60571.711 & 60571.711 & 64339.652 & 3767.94 & 3767.94 & & 64339.652 & & trace & N2 & \\
\hline $\cos$ & & & 0.666 & 0.666 & & & 0.667 & 0.018 & 0.018 & & 0.667 & & trace & $\cos$ & \\
\hline $\mathrm{ZNO}$ & & & & & & & & & & & & & & ZNO & \\
\hline ZNS & & & & & & & & & & & & 304172 & & ZNS & \\
\hline AL2O3 & & & & & & & & & & & & 1106450 & & AL2O3 & \\
\hline
\end{tabular}




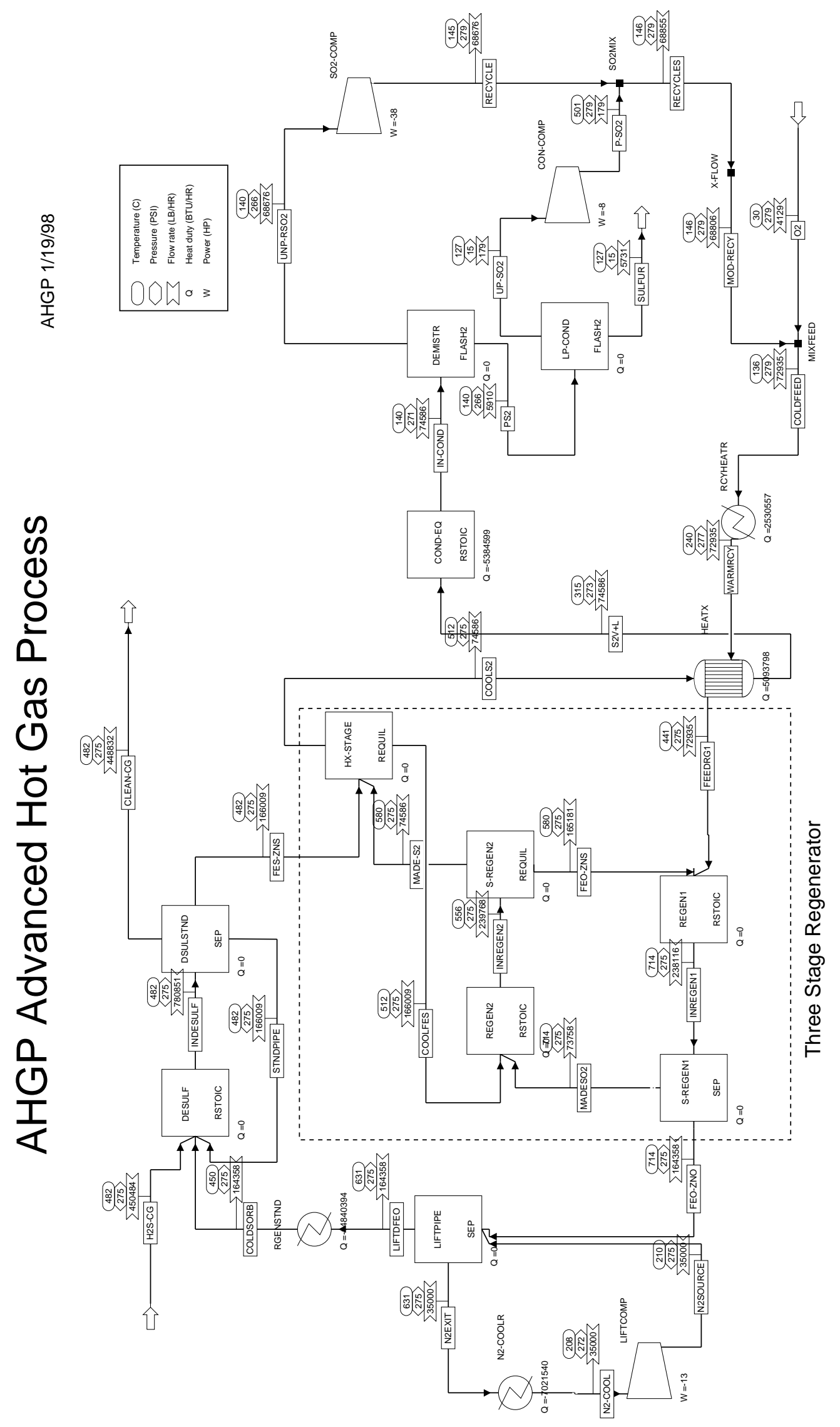




\section{AHGP 1/19/98 pg1}

\begin{tabular}{|c|c|c|c|c|c|c|c|c|c|c|c|c|c|c|}
\hline $\begin{array}{l}\text { Display ALLS } \\
\text { Units: } \\
\text { Format: SOLI }\end{array}$ & $\begin{array}{l}\text { TREAMS } \\
\text { From } \\
\text { DS To } \\
\text { Phas } \\
\text { [C] }\end{array}$ & \begin{tabular}{|l|} 
CLEAN-CG \\
DSULSTND \\
VAPOR \\
482.4
\end{tabular} & \begin{tabular}{l} 
COLDFEED \\
MIXFEED \\
RCYHEATR \\
MIXED \\
\multicolumn{1}{l}{136.5}
\end{tabular} & \begin{tabular}{|l} 
COLDSORB \\
RGENSTND \\
DESULF \\
MISSING
\end{tabular} & \begin{tabular}{|l} 
COOLFES \\
HX-STAGE \\
REGEN2 \\
MISSING \\
\multicolumn{1}{c}{512.3}
\end{tabular} & \begin{tabular}{|l|} 
COOLS2 \\
HX-STAGE \\
HEATX \\
VAPOR \\
\end{tabular} & \begin{tabular}{|l} 
FEEDRG1 \\
HEATX \\
REGEN1 \\
VAPOR \\
\multicolumn{1}{l}{440.6}
\end{tabular} & \begin{tabular}{l} 
FEO-ZNO \\
S-REGEN1 \\
LIFTPIPE \\
MISSING \\
\multicolumn{1}{c}{713.9}
\end{tabular} & \begin{tabular}{|l|} 
FEO-ZNS \\
S-REGEN2 \\
REGEN1 \\
MISSING
\end{tabular} & \begin{tabular}{|l|} 
FES-ZNS \\
DSULSTND \\
HX-STAGE \\
MISSING \\
\end{tabular} & $\begin{array}{l}\text { H2S-CG } \\
\text { DESULF } \\
\text { VAPOR }\end{array}$ & $\begin{array}{l}\text { IN-COND } \\
\text { COND-EQ } \\
\text { DEMISTR } \\
\text { MIXED }\end{array}$ & $\begin{array}{l}\text { Display ALLS } \\
\text { Units: } \\
\text { Format: SOLI }\end{array}$ & $\begin{array}{l}\text { TREAMS } \\
\text { From } \\
\text { DS To } \\
\text { Phas }\end{array}$ \\
\hline Temperature & {$[\mathrm{C}]$} & 482.4 & 136.5 & 5 & 512.3 & 512.3 & 440.6 & 713.9 & \begin{tabular}{|l|}
580.4 \\
\end{tabular} & 482.4 & 482.2 & 2 & Temperature & \\
\hline Pressure & [PSI] & 274.7 & 279.2 & 275 & 274.7 & 274.7 & 275.2 & 274.7 & 274.7 & 274.7 & 275 & 270.7 & Pressure & [PSI] \\
\hline Mass VFrac & & & & 0 & & 1 & 1 & 0 & 0 & 0 & 1 & 0.921 & Mass VFrac & \\
\hline Mass SFrac & & $<0.001$ & 0 & 1 & 1 & 0 & 0 & 1 & 1 & 1 & 0 & & Mass SFrac & \\
\hline$* * \star A L L ~ P H A S$ & $E S^{* * *}$ & & & & & & & & & & & & $* * *$ ALL PHAS & $E S^{* * *}$ \\
\hline Mass Flow & {$[\mathrm{LB} / \mathrm{HR}]$} & 448832.344 & 72935.094 & 164357.922 & 166009.453 & 74586.227 & 72935.094 & 164357.922 & 165181.094 & 166009.453 & 450483.875 & 74586.227 & Mass Flow & {$[\mathrm{LB} / \mathrm{HR}]$} \\
\hline Volume Flow & {$[\mathrm{CUFT} / \mathrm{HR}]$} & $1.13 \mathrm{E}+06$ & 30858.555 & 756.208 & 793.141 & 60581.492 & 59761.762 & 756.208 & 768.468 & 793.141 & $1.13 \mathrm{E}+06$ & $2.82 \mathrm{E}+04$ & Volume Flow & [CUFT/HR] \\
\hline Enthalpy & {$[\mathrm{BTU} / \mathrm{HR}]$} & $-1.09 \mathrm{E}+09$ & $-1.35 \mathrm{E}+08$ & $-1.06 \mathrm{E}+09$ & $-1.03 \mathrm{E}+09$ & $-1.25 \mathrm{E}+08$ & $-1.28 \mathrm{E}+08$ & $-1.04 \mathrm{E}+09$ & $-1.04 \mathrm{E}+09$ & $-1.04 \mathrm{E}+09$ & $-1.07 \mathrm{E}+09$ & $-1.35 \mathrm{E}+08$ & Enthalpy & [BTU/HR] \\
\hline Density & [LB/CUFT] & 0.397 & 2.364 & 217.345 & 209.306 & 1.231 & 1.22 & 217.345 & 214.949 & 209.306 & 0.399 & 2.645 & Density & [LB/CUFT] \\
\hline \begin{tabular}{|l|} 
Mass Flow \\
\end{tabular} & {$[\mathrm{LB} / \mathrm{HR}]$} & & & & & & & & & & & & Mass Flow & {$[\mathrm{LB} / \mathrm{HR}]$} \\
\hline $\mathrm{O} 2 \mathrm{~S}$ & & & 68800 & & & 68860.266 & 68800 & & & & & 68860.266 & $\mathrm{O} 2 \mathrm{~S}$ & \\
\hline $\mathrm{H} 2 \mathrm{~S}$ & & 23.01 & & & & & & & & & 6134.738 & & $\mathrm{H} 2 \mathrm{~S}$ & \\
\hline $\mathrm{H} 2 \mathrm{O}$ & & 73613.648 & & & & & & & & & 68998.523 & & $\mathrm{H} 2 \mathrm{O}$ & \\
\hline S2 & & & & & & $\begin{array}{l}519.707 \\
\end{array}$ & & & & & & & S2 & \\
\hline 56 & & & 2.397 & & & 2171.238 & 2.397 & & & & & 2181.632 & 56 & \\
\hline 58 & & & 3.894 & & & 3035.012 & 3.894 & & & & & 3544.325 & 58 & \\
\hline CO & & 213439.25 & & & & & & & & & 213439.25 & & CO & \\
\hline $\mathrm{CO} 2$ & & 114865.578 & & & & & & & & & 114865.578 & & $\mathrm{CO} 2$ & \\
\hline $\mathrm{H} 2$ & & 11355.747 & & & & & & & & & 11510.675 & & $\mathrm{H} 2$ & \\
\hline $\mathrm{O} 2$ & & & 4128.805 & & & & 4128.805 & & & & & & $\mathrm{O} 2$ & \\
\hline N2 & & 35535.098 & & & & & & & & & 35535.098 & & N2 & \\
\hline $\cos$ & & & & & & & & & & & & & $\cos$ & \\
\hline ZNO & & & & 2084.988 & & & & 2084.988 & & & & & ZNO & \\
\hline ZNS & & & & & 2496.573 & & & & 2496.573 & 2496.573 & & & ZNS & \\
\hline FE2O3 & & & & 12272.938 & & & & 12272.938 & 8199.015 & & & & FE2O3 & \\
\hline FEO & & & & & & & & & & & & & \begin{tabular}{|l|l|} 
FEO \\
\end{tabular} & \\
\hline FES & & 0.001 & & & 13512.88 & & & & 4485.513 & 13512.88 & & & FES & \\
\hline AL2O3 & & & & 150000 & 150000 & & & 150000 & 150000 & 150000 & & & AL2O3 & \\
\hline
\end{tabular}


AHGP 1/19/98 pg2

\begin{tabular}{|c|c|c|c|c|c|c|c|c|c|c|c|c|}
\hline 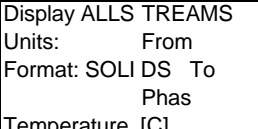 & $\mid$\begin{tabular}{|l|} 
INDESULF \\
DESULF \\
DSULSTND \\
VAPOR \\
\end{tabular} & $\begin{array}{l}\text { INREGEN1 } \\
\text { REGEN1 } \\
\text { S-REGEN1 } \\
\text { VAPOR }\end{array}$ & \begin{tabular}{|l|} 
INREGEN2 \\
REGEN2 \\
S-REGEN2 \\
VAPOR \\
\end{tabular} & \begin{tabular}{|l|} 
LIFTDFEO \\
LIFTPIPE \\
RGENSTND \\
MISSING
\end{tabular} & \begin{tabular}{|l|} 
MADE-S2 \\
S-REGEN2 \\
HX-STAGE \\
VAPOR \\
\end{tabular} & \begin{tabular}{|l|} 
MADESO2 \\
S-REGEN1 \\
REGEN2 \\
VAPOR \\
\end{tabular} & $\begin{array}{l}\text { MOD-RECY } \\
\text { X-FLOW } \\
\text { MIXFEED } \\
\text { VAPOR } \\
\end{array}$ & \begin{tabular}{|l|} 
N2-COOL \\
N2-COOLR \\
LIFTCOMP \\
VAPOR
\end{tabular} & \begin{tabular}{|l|} 
N2EXIT \\
LIFTPIPE \\
N2-COOLR \\
VAPOR
\end{tabular} & $\begin{array}{l}\text { N2SOURCE } \\
\text { LIFTCOMP } \\
\text { LIFTPIPE } \\
\text { VAPOR } \\
\end{array}$ & \begin{tabular}{|l|} 
O2 \\
MIXFEED \\
VAPOR
\end{tabular} & \begin{tabular}{|lc} 
Display ALLS TREAMS \\
Units: & From \\
Format: SOLI DS To & \multicolumn{2}{c}{ Phas } \\
\end{tabular} \\
\hline \begin{tabular}{|ll} 
Pressure & {$[\mathrm{PSI}]$} \\
\end{tabular} & $\begin{array}{l}274.7 \\
\end{array}$ & 274.7 & \begin{tabular}{|l|}
274.7 \\
\end{tabular} & \begin{tabular}{|r|}
274.7 \\
\end{tabular} & \begin{tabular}{|l|}
274.7 \\
\end{tabular} & 274.7 & \begin{tabular}{|l|}
279.2 \\
\end{tabular} & 272 & 274.7 & \begin{tabular}{|r|}
275 \\
\end{tabular} & 279.2 & Pressure [PSI] \\
\hline Mass VFrac & 0.575 & 0.31 & 0.311 & 0 & 1 & 1 & 1 & 1 & 1 & 1 & & Mass VFrac \\
\hline Mass SFrac & 0.425 & 0.69 & 0.689 & 1 & 0 & 0 & 0 & 0 & 0 & 0 & & Mass SFrac \\
\hline$* * *$ ALL PHASES ${ }^{* * *}$ & & & & & & & & & & & & $* * \star *$ ALL PHASES ${ }^{* * *}$ \\
\hline Mass Flow [LB/HR] & 780850.875 & 238116.203 & 239767.375 & 164357.922 & 74586.227 & 73758.273 & 68806.289 & 35000 & 35000 & 35000 & 4128.805 & Mass Flow [LB/HR] \\
\hline Volume Flow [CUFT/HR] & 1132710 & $8.08 \mathrm{E}+04$ & 68028.672 & 756.208 & 66784.258 & 80083.75 & 27821.109 & 43008.844 & 79902.289 & 42726.648 & 2669.199 & Volume Flow [CUFT/HR] \\
\hline Enthalpy $\quad[\mathrm{BTU} / \mathrm{HR}]$ & $-3.16 \mathrm{E}+09$ & $-1.17 \mathrm{E}+09$ & $-1.16 \mathrm{E}+09$ & $-1.05 \mathrm{E}+09$ & $-1.22 \mathrm{E}+08$ & $-1.30 \mathrm{E}+08$ & $-1.35 \mathrm{E}+08$ & 2866710 & $9.89 \mathrm{E}+06$ & 2899740 & \begin{tabular}{ll|}
-1712.78 \\
\end{tabular} & $\begin{array}{ll}\text { Enthalpy } & {[\mathrm{BTU} / \mathrm{HR}]} \\
\end{array}$ \\
\hline$[\mathrm{LB} / \mathrm{CUFT}]$ & 0.689 & 2.946 & 3.525 & 217.345 & 1.117 & 0.921 & 2.473 & (0.814 & 0.438 & $\begin{array}{r}0.819 \\
\end{array}$ & 1.547 & [LB/CUFT] \\
\hline Mass Flow & & & & & & & & & & & & \begin{tabular}{|l|} 
Mass Flow \\
\end{tabular} \\
\hline $\mathrm{O} 2 \mathrm{~S}$ & & 73722.469 & 68860.266 & & 68860.266 & 73722.469 & 68800 & & & & & O2S \\
\hline $\mathrm{H} 2 \mathrm{~S}$ & 23.01 & & & & & & & & & & & $\mathrm{H} 2 \mathrm{~S}$ \\
\hline $\mathrm{H} 2 \mathrm{O}$ & 73613.648 & & & & & & & & & & & $\mathrm{H} 2 \mathrm{O}$ \\
\hline S2 & & & 5726 & & 1563.893 & & & & & & & S2 \\
\hline 56 & & & & & 2146.613 & & 2.397 & & & & & S6 \\
\hline S8 & & & & & 2015.451 & & 3.894 & & & & & S8 \\
\hline $\mathrm{CO}$ & 213439.25 & & & & & & & & & & & $\mathrm{CO}$ \\
\hline $\mathrm{CO} 2$ & 114865.578 & & & & & & & & & & & $\mathrm{CO} 2$ \\
\hline $\mathrm{H} 2$ & 11355.747 & & & & & & & & & & & $\mathrm{H} 2$ \\
\hline $\mathrm{O} 2$ & & 35.801 & & & & 35.801 & & & & & 4128.805 & $\mathrm{O} 2$ \\
\hline N2 & 35535.098 & & & & & & & 35000 & 35000 & 35000 & & N2 \\
\hline $\cos$ & & & & & & & & & & & & cos \\
\hline ZNO & & 2084.988 & & 2084.988 & & & & & & & & ZNO \\
\hline ZNS & 4993.106 & & 2496.573 & & & & & & & & & ZNS \\
\hline $\mathrm{FE} 2 \mathrm{O} 3$ & & 12272.938 & 8199.016 & 12272.938 & & & & & & & & FE2O3 \\
\hline FEO & & & & & & & & & & & & FEO \\
\hline FES & 27025.441 & & 4485.513 & & & & & & & & & FES \\
\hline AL2O3 & 300000 & 150000 & 150000 & 150000 & & & & & & & & AL2O3 \\
\hline
\end{tabular}


AHGP 1/19/98 pg3

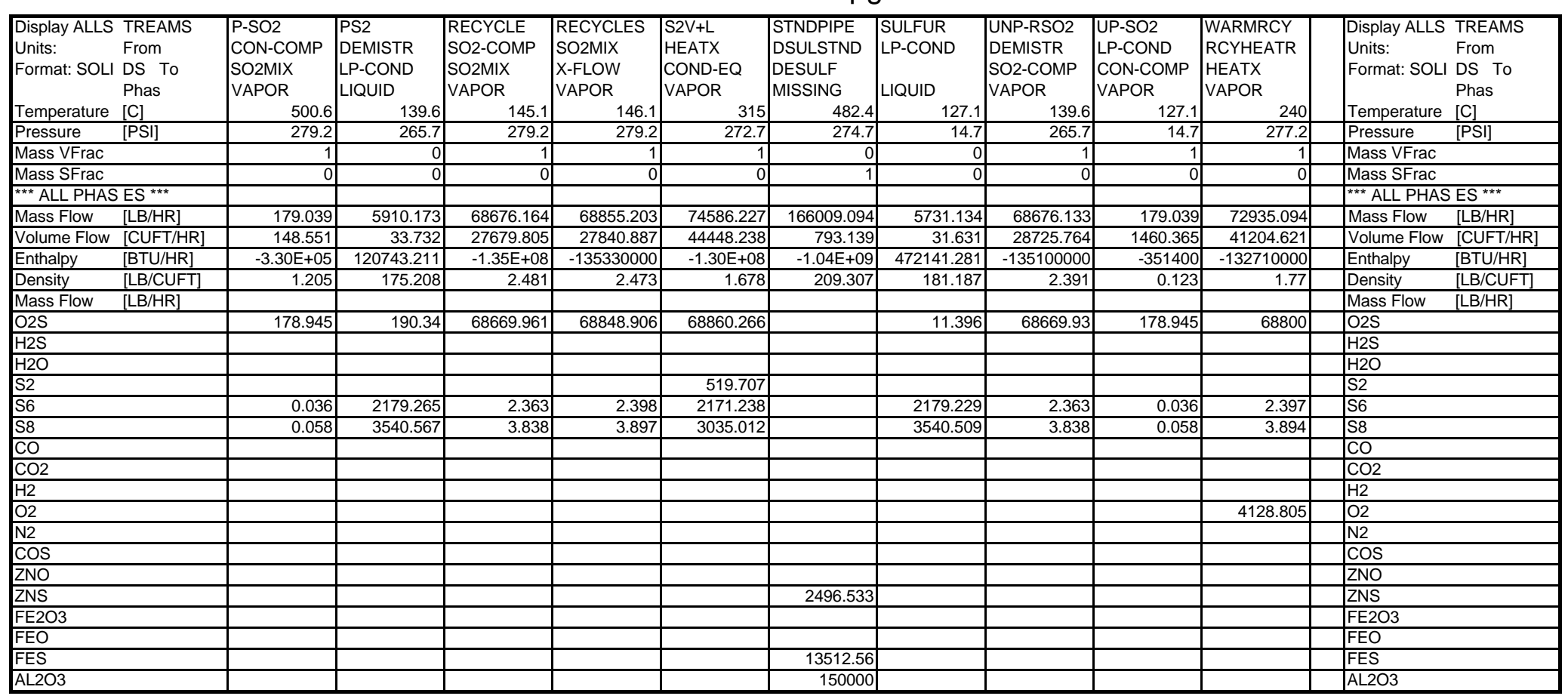




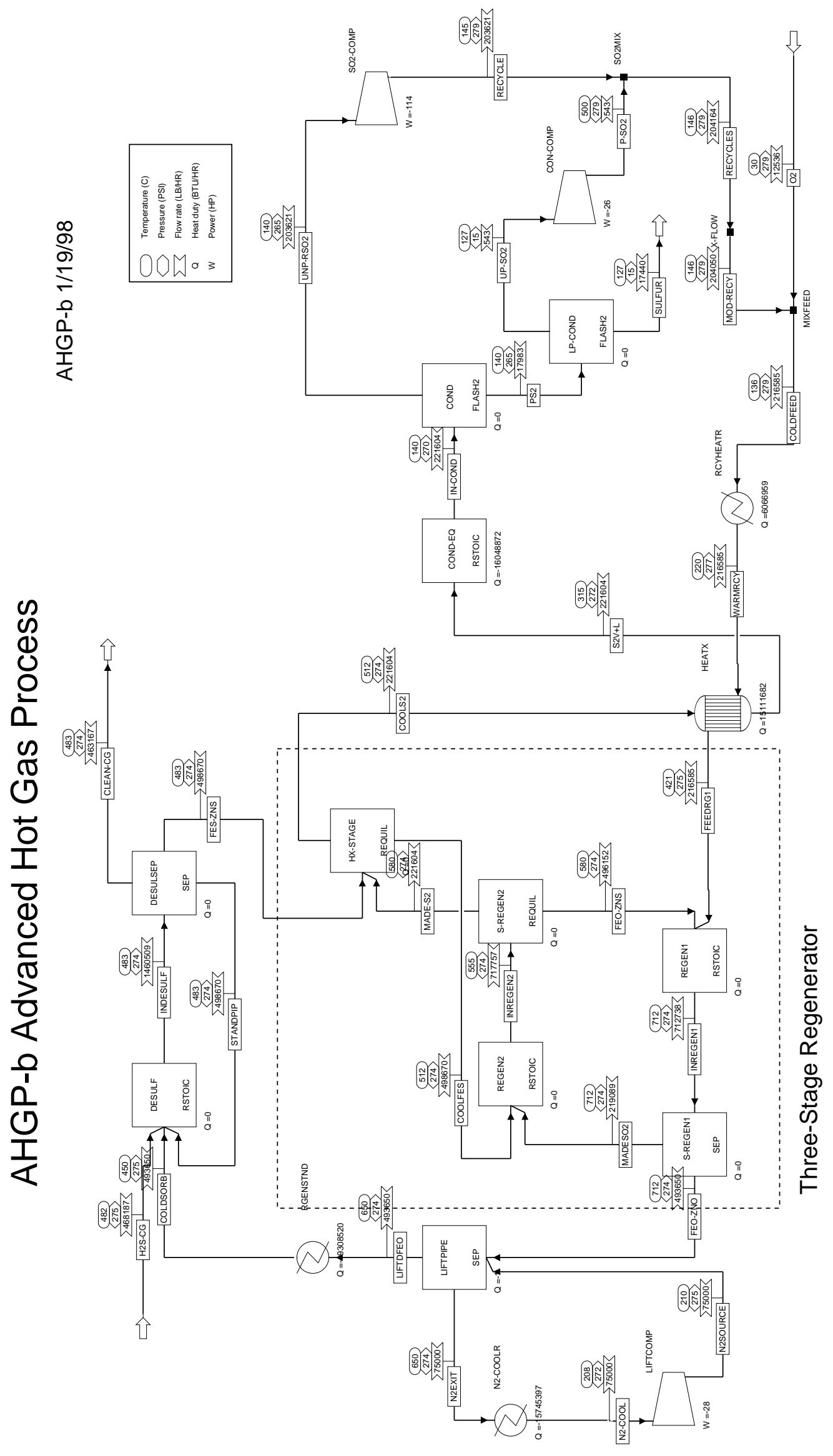




\section{AHGP-b 1/19/98 pg1}

\begin{tabular}{|c|c|c|c|c|c|c|c|c|c|c|c|c|c|c|}
\hline $\begin{array}{l}\text { Display ALLS T } \\
\text { Units: } \\
\text { Format: SOLI D }\end{array}$ & $\begin{array}{l}\text { TREAMS } \\
\text { From } \\
\text { IDS To } \\
\text { Phas }\end{array}$ & \begin{tabular}{|l|} 
CLEAN-CG \\
DESULSEP \\
VAPOR
\end{tabular} & $\begin{array}{l}\text { COLDFEED } \\
\text { MIXFEED } \\
\text { RCYHEATR } \\
\text { MIXED }\end{array}$ & \begin{tabular}{|l|} 
COLDSORB \\
RGENSTND \\
DESULF \\
MISSING
\end{tabular} & \begin{tabular}{|l|} 
COOLFES \\
HX-STAGE \\
REGEN2 \\
MISSING
\end{tabular} & \begin{tabular}{|l|} 
COOLS2 \\
HX-STAGE \\
HEATX \\
VAPOR
\end{tabular} & \begin{tabular}{|l|} 
FEEDRG1 \\
HEATX \\
REGEN1 \\
VAPOR
\end{tabular} & \begin{tabular}{|l|} 
FEO-ZNO \\
S-REGEN1 \\
LIFTPIPE \\
MISSING
\end{tabular} & \begin{tabular}{|l|} 
FEO-ZNS \\
S-REGEN2 \\
REGEN1 \\
MISSING
\end{tabular} & \begin{tabular}{|l|} 
FES-ZNS \\
DESULSEP \\
HX-STAGE \\
MISSING
\end{tabular} & \begin{tabular}{|l|} 
H2S-CG \\
DESULF \\
VAPOR
\end{tabular} & $\begin{array}{l}\text { IN-COND } \\
\text { COND-EQ } \\
\text { COND } \\
\text { MIXED }\end{array}$ & $\begin{array}{l}\text { Display ALLS } \\
\text { Units: } \\
\text { Format: SOLI }\end{array}$ & $\begin{array}{l}\text { TREAMS } \\
\text { From } \\
\text { DS To } \\
\text { Phas }\end{array}$ \\
\hline Temperature & {$[\mathrm{C}]$} & 482.7 & 136.3 & 450 & 512.1 & 512.1 & 421.5 & 711.6 & 579.5 & 482.7 & 482.2 & 140 & Temperature & {$[\mathrm{C}]$} \\
\hline Pressure & [PSI] & 274.1 & 278.6 & 275 & 274.1 & 274.1 & 274.6 & 274.1 & 274.1 & 274.1 & 275 & 270.1 & Pressure & [PSI] \\
\hline Mass SFrac & & 0 & 0 & 1 & 1 & 0 & 0 & 1 & 1 & 1 & 0 & 0 & Mass SFrac & \\
\hline *** ALL PHASE & $\mathrm{ES}^{\star \star \star}$ & & & & & & & & & & & & *** ALL PHAS & $E S^{* * *}$ \\
\hline Mass Flow & {$[\mathrm{LB} / \mathrm{HR}]$} & 463167.313 & 216585.75 & 493649.531 & 498669.813 & 221603.984 & 216585.75 & 493649.531 & 496152.125 & 498669.813 & 468187.563 & 221603.984 & Mass Flow & {$[\mathrm{LB} / \mathrm{HR}]$} \\
\hline Volume Flow [ & [CUFT/HR] & $1.17 \mathrm{E}+06$ & 91955.008 & \begin{tabular}{r|}
2270.583 \\
\end{tabular} & 2382.878 & 180074.938 & 173024.047 & 2270.583 & 2307.888 & $\begin{array}{r}2382.878 \\
\end{array}$ & $1.16 \mathrm{E}+06$ & $8.38 \mathrm{E}+04$ & Volume Flow & [CUFT/HR] \\
\hline Enthalpy & [BTU/HR] & $-1.16 \mathrm{E}+09$ & $-4.01 \mathrm{E}+08$ & $-3.18 \mathrm{E}+09$ & $-3.10 \mathrm{E}+09$ & $-3.69 \mathrm{E}+08$ & $-3.80 \mathrm{E}+08$ & $-3.12 \mathrm{E}+09$ & $-3.13 \mathrm{E}+09$ & $-3.11 \mathrm{E}+09$ & $-1.08 \mathrm{E}+09$ & $-4.00 \mathrm{E}+08$ & Enthalpy & [BTU/HR] \\
\hline \begin{tabular}{|l|} 
Density \\
\end{tabular} & [LB/CUFT] & $\begin{array}{l}0.397 \\
\end{array}$ & 2.355 & \begin{tabular}{|l|}
217.411 \\
\end{tabular} & 209.272 & $\begin{array}{l}1.231 \\
\end{array}$ & $\begin{array}{r}1.252 \\
\end{array}$ & \begin{tabular}{|l|}
217.411 \\
\end{tabular} & 214.981 & 209.272 & $\begin{array}{l}0.403 \\
\end{array}$ & $\begin{array}{r}2.643 \\
\end{array}$ & \begin{tabular}{|l|} 
Density \\
\end{tabular} & [LB/CUFT] \\
\hline Mass Flow & {$[\mathrm{LB} / \mathrm{HR}]$} & & & & & & & & & & & & \begin{tabular}{|l|} 
Mass Flow \\
\end{tabular} & {$[\mathrm{LB} / \mathrm{HR}]$} \\
\hline O2S & & & 204031.219 & & & 204180.078 & 204031.219 & & & & & 204180.078 & $\mathrm{O} 2 \mathrm{~S}$ & \\
\hline $\mathrm{H} 2 \mathrm{~S}$ & & 23.471 & & & & & & & & & 18603.785 & & $\mathrm{H} 2 \mathrm{~S}$ & \\
\hline $\mathrm{H} 2 \mathrm{O}$ & & 83842.484 & & & & & & & & & 69811.359 & & $\mathrm{H} 2 \mathrm{O}$ & \\
\hline S2 & & & & & & 1549.572 & & & & & & & S2 & \\
\hline 56 & & & 7.099 & & & 6588.625 & 7.099 & & & & & 6619.617 & 56 & \\
\hline S8 & & & 11.587 & & & 9285.715 & 11.587 & & & & & 10804.296 & S8 & \\
\hline $\mathrm{CO}$ & & 215953.672 & & & & & & & & & 215953.672 & & $\mathrm{CO}$ & \\
\hline $\mathrm{CO} 2$ & & 116218.758 & & & & & & & & & 116218.758 & & \begin{tabular}{|l|}
$\mathrm{CO} 2$ \\
\end{tabular} & \\
\hline $\mathrm{H} 2$ & & 11175.208 & & & & & & & & & 11646.276 & & $\mathrm{H} 2$ & \\
\hline $\mathrm{O} 2$ & & & 12535.85 & & & & 12535.85 & & & & & & $\mathrm{O} 2$ & \\
\hline N2 & & 35953.723 & & & & & & & & & 35953.723 & & N2 & \\
\hline ZNS & & & & & 7583 & & & & 7583 & 7583 & & & ZNS & \\
\hline $\mathrm{FE2O3}$ & & & & 37316.672 & & & & 37316.672 & 24919.895 & & & & FE2O3 & \\
\hline FEO & & & & & & & & & & & & & FEO & \\
\hline FES & & & & & 41086.797 & & & & 13649.23 & 41086.797 & & & \begin{tabular}{|l|l|} 
FES \\
\end{tabular} & \\
\hline AL2O3 & & & & 450000 & 450000 & & & 450000 & 450000 & 450000 & & & AL2O3 & \\
\hline
\end{tabular}




\section{AHGP-b 1/19/98 pg2}

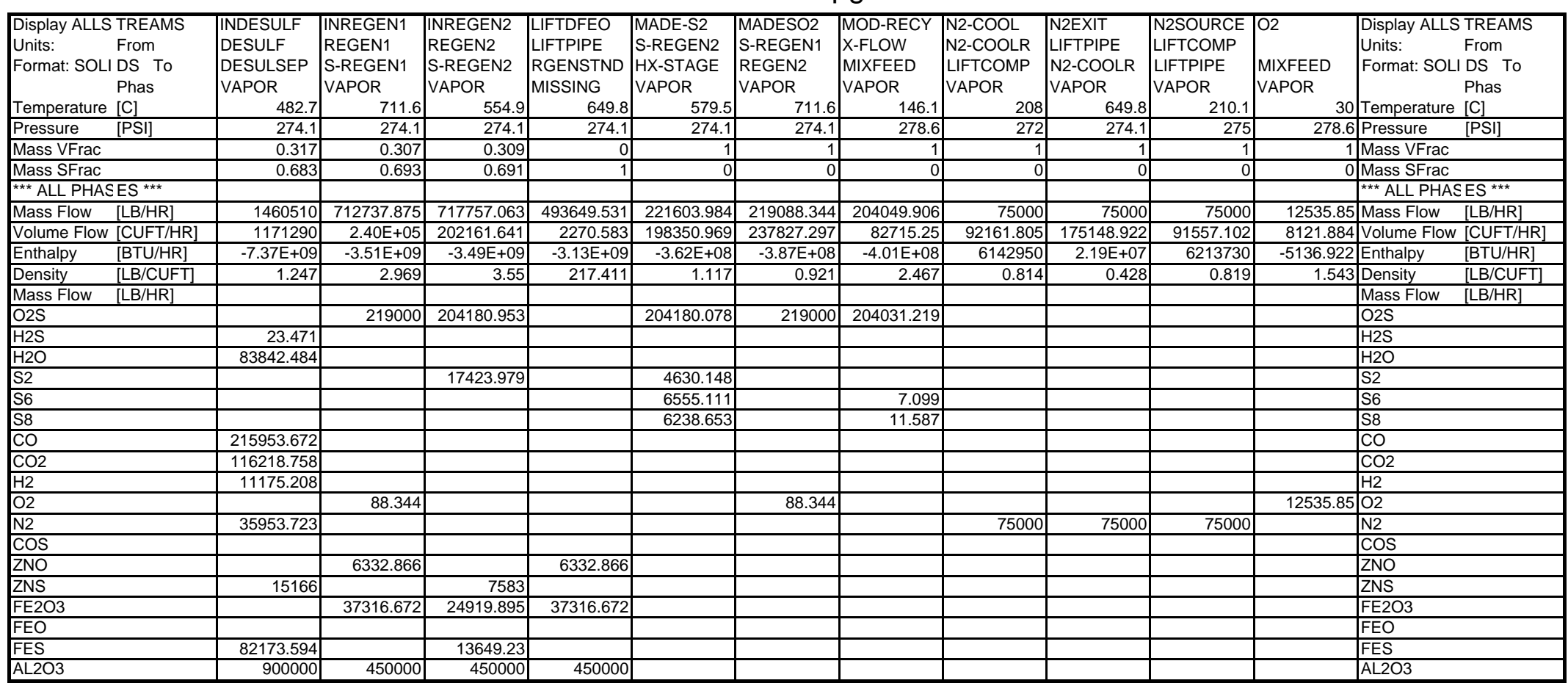


AHGP-b 1/19/98 pg3

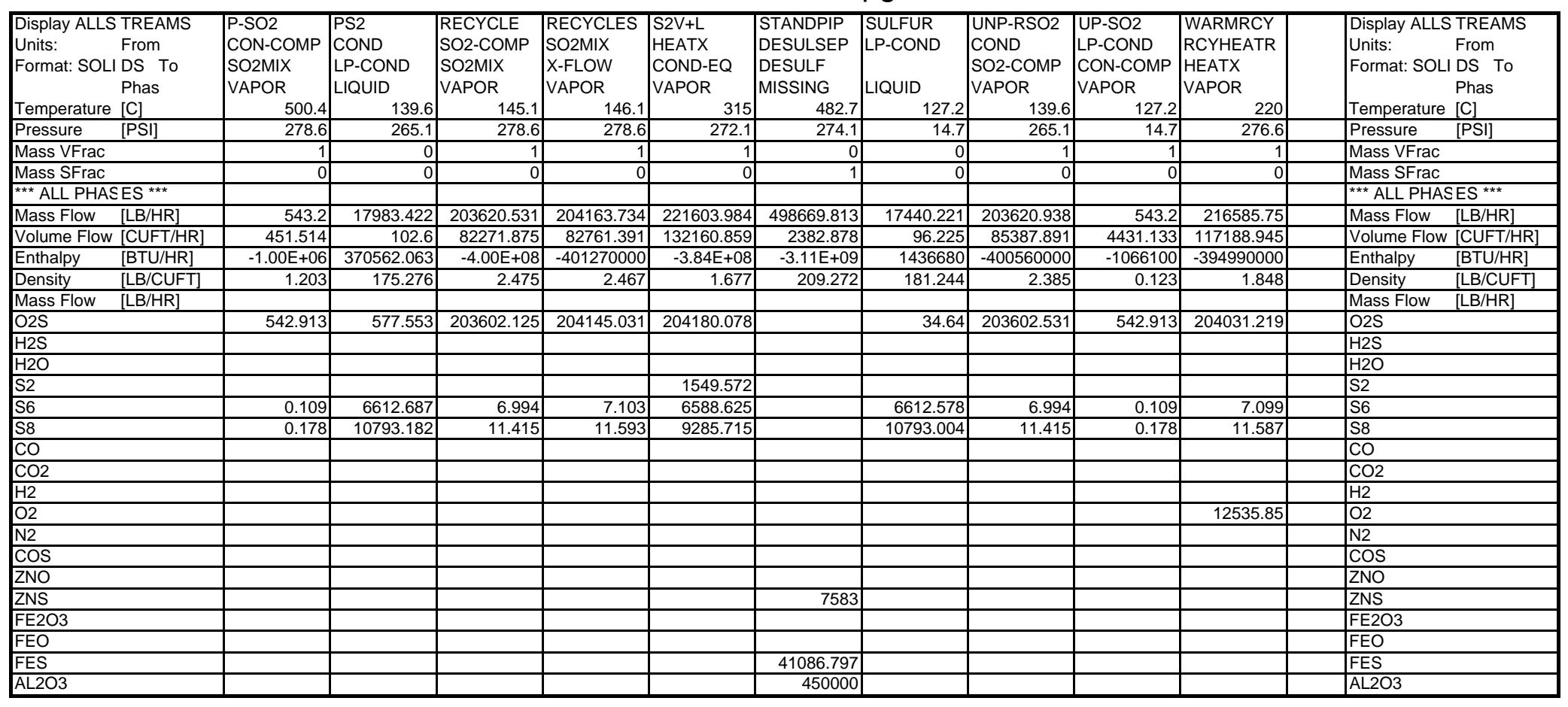




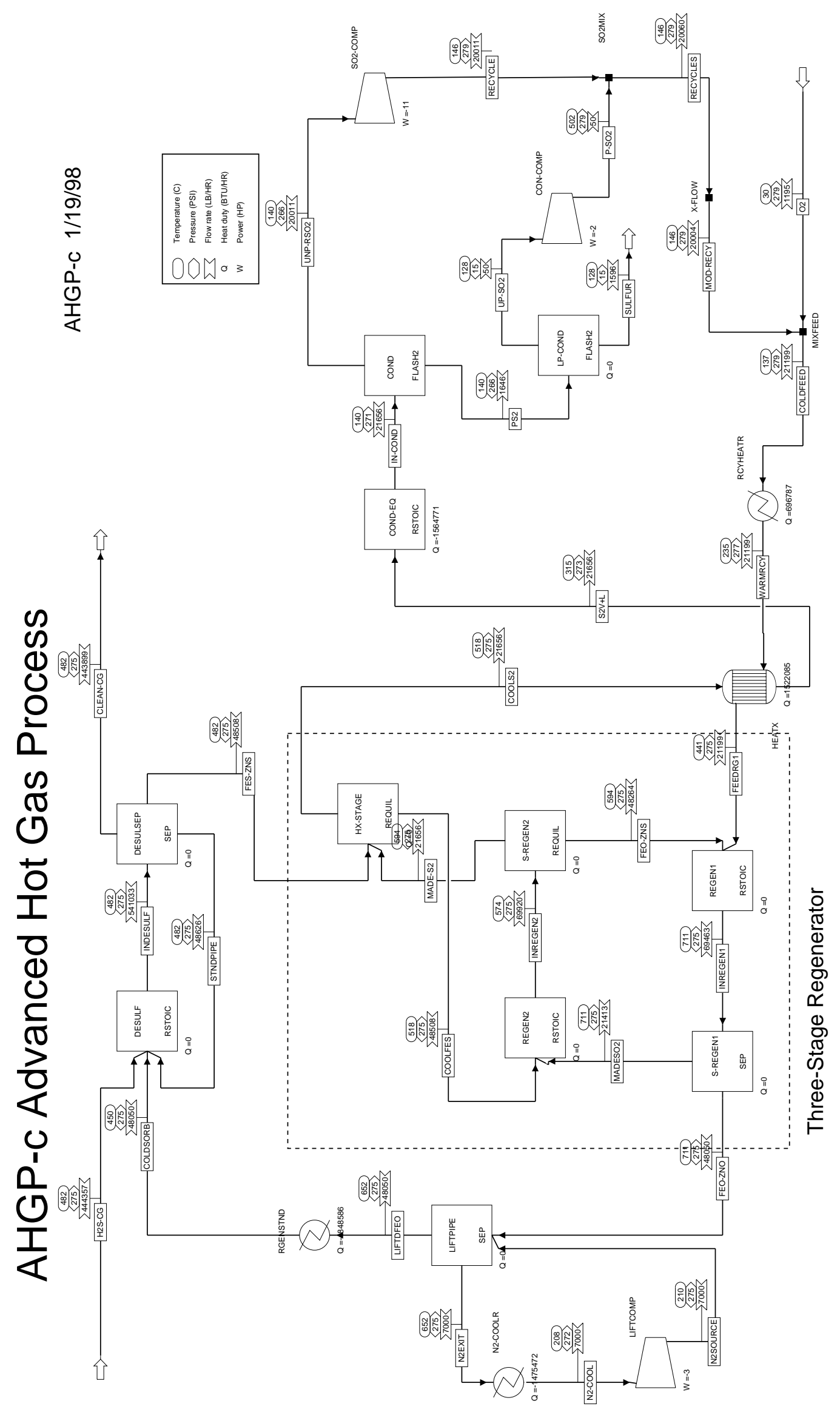


AHGP-c 1/19/98 pg1

\begin{tabular}{|c|c|c|c|c|c|c|c|c|c|c|c|c|c|c|}
\hline $\begin{array}{l}\text { Display ALLS } \\
\text { Units: } \\
\text { Format: SOLI }\end{array}$ & $\begin{array}{l}\text { TREAMS } \\
\text { From } \\
\text { I DS To } \\
\text { Phas }\end{array}$ & \begin{tabular}{|l|} 
CLEAN-CG \\
DESULSEP \\
VAPOR
\end{tabular} & \begin{tabular}{|l|} 
COLDFEED \\
MIXFEED \\
RCYHEATR \\
MIXED
\end{tabular} & \begin{tabular}{|l|} 
COLDSORB \\
RGENSTND \\
DESULF \\
MISSING \\
\end{tabular} & \begin{tabular}{|l|} 
COOLFES \\
HX-STAGE \\
REGEN2 \\
MISSING \\
\end{tabular} & \begin{tabular}{|l|} 
COOLS2 \\
HX-STAGE \\
HEATX \\
VAPOR \\
\end{tabular} & \begin{tabular}{|l|} 
FEEDRG1 \\
HEATX \\
REGEN1 \\
VAPOR
\end{tabular} & \begin{tabular}{|l|} 
FEO-ZNO \\
S-REGEN1 \\
LIFTPIPE \\
MISSING
\end{tabular} & \begin{tabular}{|l|} 
FEO-ZNS \\
S-REGEN2 \\
REGEN1 \\
MISSING
\end{tabular} & \begin{tabular}{|l|} 
FES-ZNS \\
DESULSEP \\
HX-STAGE \\
MISSING
\end{tabular} & \begin{tabular}{|l|} 
H2S-CG \\
DESULF \\
VAPOR
\end{tabular} & $\begin{array}{l}\text { IN-COND } \\
\text { COND-EQ } \\
\text { DEMISTR } \\
\text { MIXED }\end{array}$ & $\begin{array}{l}\text { Display ALLS } \\
\text { Units: } \\
\text { Format: SOLI }\end{array}$ & $\begin{array}{l}\text { TREAMS } \\
\text { From } \\
\text { DS To } \\
\text { Phas }\end{array}$ \\
\hline Temperature & & 482.1 & 136.9 & 450 & 517.8 & 517.8 & 441.4 & 711 & 594.5 & 482.1 & 482.2 & 140 & Temperature & \\
\hline Pressure & [PSI] & 274.9 & 279.4 & 275 & 274.9 & 274.9 & 275.4 & 275.4 & 275.4 & 274.9 & 275 & 270.9 & Pressure & {$[\mathrm{PSI}]$} \\
\hline Mass VFrac & & & 1 & 0 & 0 & 1 & 1 & 0 & 0 & 0 & 1 & 0.924 & Mass VFrac & \\
\hline Mass SFrac & & 0 & 0 & 1 & 1 & 0 & 0 & 1 & 1 & 1 & 0 & 0 & Mass SFrac & \\
\hline${ }^{* \star \star}$ ALL PHAS & $E S^{* * *}$ & & & & & & & & & & & & ***A ALL PHAS & $\mathrm{ES}^{* * *}$ \\
\hline Mass Flow & {$[\mathrm{LB} / \mathrm{HR}]$} & 443898.906 & 21199.451 & 48050.277 & 48507.699 & 21656.5 & 21199.451 & 48050.277 & 48263.68 & 48507.699 & 444356.313 & 21656.5 & Mass Flow & {$[\mathrm{LB} / \mathrm{HR}]$} \\
\hline Volume Flow & {$[\mathrm{CUFT} / \mathrm{HR}$} & $1.12 \mathrm{E}+06$ & 8971.891 & \begin{tabular}{r|}
221.013 \\
\end{tabular} & $\begin{array}{r}231.696 \\
\end{array}$ & 17760.699 & 17373.199 & $\begin{array}{r}221.013 \\
\end{array}$ & 224.428 & 231.696 & $1.12 \mathrm{E}+06$ & $8.21 \mathrm{E}+03$ & Volume Flow & [CUFT/HR] \\
\hline Enthalpy & {$[\mathrm{BTU} / \mathrm{HR}]$} & $-1.07 E+09$ & $-3.93 E+07$ & $-3.11 E+08$ & $-3.03 E+08$ & $-3.62 E+07$ & $-3.71 \mathrm{E}+07$ & $-3.05 \mathrm{E}+08$ & $-3.05 \mathrm{E}+08$ & $-3.04 \mathrm{E}+08$ & $-1.06 \mathrm{E}+09$ & $-3.93 \mathrm{E}+07$ & Enthalpy & {$[\mathrm{BTU} / \mathrm{HR}]$} \\
\hline Density & [LB/CUFT] & 0.397 & 2.363 & 217.409 & 209.359 & 1.219 & 1.22 & 217.409 & 215.052 & 209.359 & 0.397 & 2.638 & Density & [LB/CUFT] \\
\hline \begin{tabular}{|l|} 
Mass Flow \\
\end{tabular} & {$[\mathrm{LB} / \mathrm{HR}]$} & & & & & & & & & & & & \begin{tabular}{|l|} 
Mass Flow \\
\end{tabular} & {$[\mathrm{LB} / \mathrm{HR}]$} \\
\hline $\mathrm{O} 2 \mathrm{~S}$ & & & 20002.434 & & & 20061.83 & 20002.434 & & & & & 20061.83 & $\mathrm{O} 2 \mathrm{~S}$ & \\
\hline $\mathrm{H} 2 \mathrm{~S}$ & & 65.815 & & & & & & & & & 1790.604 & & $\mathrm{H} 2 \mathrm{~S}$ & \\
\hline $\mathrm{H} 2 \mathrm{O}$ & & 70033.773 & & & & & & & & & 68721.594 & & $\mathrm{H} 2 \mathrm{O}$ & \\
\hline S2 & & & & & & 164.784 & & & & & & & S2 & \\
\hline 56 & & & 0.719 & & & 612.014 & 0.719 & & & & & 615.31 & 56 & \\
\hline S8 & & & $\begin{array}{l}.1 .144 \\
\end{array}$ & & & $\begin{array}{l}817.872 \\
\end{array}$ & $\begin{array}{l}0.174 \\
1.144 \\
\end{array}$ & & & & & 979.36 & \begin{tabular}{|l|}
$S 8$ \\
58
\end{tabular} & \\
\hline $\mathrm{CO}$ & & 212582.609 & & & & & & & & & 212582.609 & & $\mathrm{co}$ & \\
\hline $\mathrm{CO} 2$ & & 114404.563 & & & & & & & & & 114404.563 & & $\mathrm{CO} 2$ & \\
\hline $\mathrm{H} 2$ & & \begin{tabular}{|c|}
11419.664 \\
\end{tabular} & & & & & & & & & 11464.477 & & \begin{tabular}{|l|l|}
$\mathrm{H} 2$ \\
\end{tabular} & \\
\hline $\mathrm{O} 2$ & & & 1195.155 & & & & 1195.155 & & & & & & $\mathrm{O} 2$ & \\
\hline N2 & & \begin{tabular}{|l|}
35392.48 \\
\end{tabular} & & & & & & & & & 35392.48 & & N2 & \\
\hline $\cos$ & & & & & & & & & & & & & $\cos$ & \\
\hline ZNO & & & & 500.379 & & & & 500.379 & & & & & ZNO & \\
\hline ZNS & & & & & 599.156 & & & & 599.156 & 599.156 & & & ZNS & \\
\hline $\mathrm{FE} 2 \mathrm{O} 3$ & & & & 3549.896 & & & & 3549.896 & 2415.33 & & & & FE2O3 & \\
\hline FEO & & & & & & & & & & & & & FEO & \\
\hline FES & & & & & 3908.545 & & & & 1249.193 & 3908.545 & & & \begin{tabular}{|l|l|} 
FES \\
\end{tabular} & \\
\hline AL2O3 & & & & 44000 & 44000 & & & 44000 & 44000 & 44000 & & & AL2O3 & \\
\hline
\end{tabular}


AHGP-c 1/19/98 pg2

\begin{tabular}{|c|c|c|c|c|c|c|c|c|c|c|c|c|c|c|}
\hline $\begin{array}{l}\text { Display ALLS } \\
\text { Units: } \\
\text { Format: SOLI }\end{array}$ & $\begin{array}{l}\text { TREAMS } \\
\text { From } \\
\text { DS To } \\
\text { Phas }\end{array}$ & \begin{tabular}{|l|} 
INDESULF \\
DESULF \\
DESULSEP \\
VAPOR
\end{tabular} & \begin{tabular}{|l|} 
INREGEN1 \\
REGEN1 \\
S-REGEN1 \\
VAPOR
\end{tabular} & \begin{tabular}{|l|} 
INREGEN2 \\
REGEN2 \\
S-REGEN2 \\
VAPOR
\end{tabular} & \begin{tabular}{|l|} 
LIFTDFEO \\
LIFTPIPE \\
RGENSTND \\
MISSING \\
\end{tabular} & \begin{tabular}{|l|} 
MADE-S2 \\
S-REGEN2 \\
HX-STAGE \\
VAPOR
\end{tabular} & \begin{tabular}{|l|} 
MADESO2 \\
S-REGEN1 \\
REGEN2 \\
VAPOR
\end{tabular} & \begin{tabular}{|l} 
MOD-RECY \\
X-FLOW \\
MIXFEED \\
VAPOR \\
\end{tabular} & $\begin{array}{l}\text { N2-COOL } \\
\text { N2-COOLR } \\
\text { LIFTCOMP } \\
\text { VAPOR }\end{array}$ & \begin{tabular}{|l|} 
N2EXIT \\
LIFTPIPE \\
N2-COOLR \\
VAPOR \\
\end{tabular} & $\begin{array}{l}\text { N2SOURCE } \\
\text { LIFTCOMP } \\
\text { LIFTPIPE } \\
\text { VAPOR }\end{array}$ & $\begin{array}{l}\text { O2 } \\
\text { MIXFEED } \\
\text { VAPOR }\end{array}$ & $\begin{array}{l}\text { Display ALLS } \\
\text { Units: } \\
\text { Format: SOLI } \\
\end{array}$ & $\begin{array}{l}\text { TREAMS } \\
\text { From } \\
\text { DS To } \\
\text { Phas }\end{array}$ \\
\hline Temperature & & & \begin{tabular}{|r|}
711 \\
\end{tabular} & \begin{tabular}{|r|}
573.5 \\
\end{tabular} & \begin{tabular}{|r|}
651.5 \\
\end{tabular} & $\begin{array}{l}594.5 \\
\end{array}$ & 711 & \begin{tabular}{|r|}
146.5 \\
\end{tabular} & 208 & $\begin{array}{r}651.5 \\
\end{array}$ & $\begin{array}{r}210.1 \\
\end{array}$ & & $\begin{array}{l}0 \text { Temperature } \\
\end{array}$ & \\
\hline Pressure & {$[\mathrm{PSI}]$} & 274.9 & 275.4 & 275.4 & 275 & 275.4 & \begin{tabular}{|l|}
275.4 \\
\end{tabular} & 279.4 & 272 & 275 & 275 & 279.4 & 4 Pressure & {$[\mathrm{PSI}]$} \\
\hline Mass VFrac & & 0.82 & 0.308 & 0.31 & 0 & 1 & & 1 & 1 & 1 & 1 & & 1 Mass VFrac & \\
\hline Mass SFrac & & 0.18 & 0.692 & 0.69 & 1 & 0 & 0 & 0 & 0 & 0 & 0 & & Mass SFrac & \\
\hline${ }^{* \star \star}$ ALL PHAS & $E S^{* \star \star}$ & 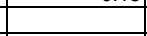 & 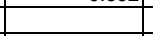 & 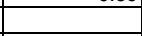 & & 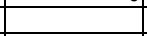 & & & & & & & ${ }^{* \star \star}$ ALL PHAS & $\mathrm{ES}^{* \star *}$ \\
\hline Mass Flow & {$[\mathrm{LB} / \mathrm{HR}]$} & 541032.563 & 69463.133 & 69920.453 & 48050.277 & 21656.5 & 21412.854 & 20004.297 & 7000 & 7000 & 7000 & 1195.155 & 5 Mass Flow & {$[\mathrm{LB} / \mathrm{HR}]$} \\
\hline Volume Flow & [CUFT/HR] & 1119290 & $2.34 \mathrm{E}+04$ & 20135.34 & 221.013 & 19779.051 & 23221.412 & 8092.941 & 8601.769 & 16324.121 & 8545.33 & 772.086 & \begin{tabular}{|l|l}
6 Volume Flow \\
\end{tabular} & [CUFT/HR] \\
\hline Enthalpy & [BTU/HR] & $-1.68 \mathrm{E}+09$ & $-3.42 E+08$ & $-3.41 E+08$ & $-3.06 \mathrm{E}+08$ & $-3.54 \mathrm{E}+07$ & $-3.76 \mathrm{E}+07$ & $-3.93 \mathrm{E}+07$ & 573341.625 & $2.05 \mathrm{E}+06$ & $\begin{array}{l}579948.125 \\
\end{array}$ & -497.809 & Enthalpy & [BTU/HR] \\
\hline Density & [LB/CUFT] & $\begin{array}{l}0.483 \\
\end{array}$ & 2.963 & 3.473 & 217.409 & 1.095 & 0.922 & $\begin{array}{r}2.472 \\
\end{array}$ & 0.814 & 0.429 & 0.819 & 1.548 & $\begin{array}{l}\text { Density } \\
\end{array}$ & [LB/CUFT] \\
\hline Mass Flow & [LB/HR] & & & & & & & & & & & & Mass Flow & {$[\mathrm{LB} / \mathrm{HR}]$} \\
\hline O2S & & & 21310.348 & 20062.115 & & 20061.83 & 21310.348 & 20002.434 & & & & & O2S & \\
\hline $\mathrm{H} 2 \mathrm{~S}$ & & 65.815 & & & & & & & & & & & $\mathrm{H} 2 \mathrm{~S}$ & \\
\hline $\mathrm{H} 2 \mathrm{O}$ & & 70033.773 & & & & & & & & & & & $\mathrm{H} 2 \mathrm{O}$ & \\
\hline S2 & & & & 1594.662 & & 542.278 & & & & & & & S2 & \\
\hline 56 & & & & & & 569.93 & & 0.719 & & & & & 56 & \\
\hline 58 & & & & & & 482.462 & & 1.144 & & & & & S8 & \\
\hline $\mathrm{CO}$ & & 212582.609 & & & & & & & & & & & $\mathrm{CO}$ & \\
\hline $\mathrm{CO} 2$ & & 114404.563 & & & & & & & & & & & $\mathrm{CO} 2$ & \\
\hline $\mathrm{H} 2$ & & 11419.664 & & & & & & & & & & & $\mathrm{H} 2$ & \\
\hline 02 & & & 102.507 & & & & 102.507 & & & & & 1195.155 & & \\
\hline N2 & & 35392.48 & & & & & & & 7000 & 7000 & 7000 & & N2 & \\
\hline $\cos$ & & & & & & & & & & & & & $\cos$ & \\
\hline $\mathrm{ZNO}$ & & & 500.379 & & 500.379 & & & & & & & & ZNO & \\
\hline ZNS & & 1316.587 & & 599.156 & & & & & & & & & ZNS & \\
\hline $\mathrm{FE} 2 \mathrm{O} 3$ & & & 3549.896 & 2415.33 & 3549.896 & & & & & & & & $\mathrm{FE} 2 \mathrm{O} 3$ & \\
\hline FEO & & & & & & & & & & & & & $\mathrm{FEO}$ & \\
\hline FES & & 7817.09 & & 1249.193 & & & & & & & & & FES & \\
\hline AL2O3 & & 88000 & 44000 & 44000 & 44000 & & & & & & & & AL2O3 & \\
\hline
\end{tabular}


AHGP-c 1/19/98 pg3

\begin{tabular}{|c|c|c|c|c|c|c|c|c|c|c|c|c|c|}
\hline \begin{tabular}{|l} 
Display ALLS \\
Units: \\
Format: SOLI \\
Temperature \\
\end{tabular} & $\begin{array}{l}\text { TREAMS } \\
\text { From } \\
\text { DS To } \\
\text { Phas } \\
\text { [C] } \\
\end{array}$ & \begin{tabular}{|l} 
P-SO2 \\
CON-COMP \\
SO2MIX \\
VAPOR \\
$\quad 501.6$ \\
\end{tabular} & \begin{tabular}{|l|} 
PS2 \\
DEMISTR \\
LP-COND \\
LIQUID \\
\\
\end{tabular} & \begin{tabular}{|l|l|} 
RECYCLE & SO2-COMPP \\
SO2MIX \\
VAPOR \\
\multicolumn{1}{|c|}{145.5} \\
\end{tabular} & \begin{tabular}{|l|} 
RECYCLES \\
SO2MIX \\
X-FLOW \\
VAPOR \\
$\quad 146.5$ \\
\end{tabular} & \begin{tabular}{|l} 
S2V+L \\
HEATX \\
COND-EQ \\
VAPOR \\
$\quad$ \\
\end{tabular} & \begin{tabular}{|l|} 
STNDPIPE \\
DESULSEP \\
DESULF \\
MISSING \\
$\quad 482.1$
\end{tabular} & \begin{tabular}{|l|}
$\begin{array}{l}\text { SULFUR } \\
\text { LP-COND } \\
\text { LIQUID } \\
\\
127.7\end{array}$ \\
\end{tabular} & \begin{tabular}{|l} 
UNP-RSO2 \\
DEMISTR \\
SO2-COMP \\
VAPOR \\
$\quad 140$ \\
\end{tabular} & \begin{tabular}{|l|l} 
UP-SO2 \\
LP-COND \\
CON-COMP \\
VAPOR \\
\multicolumn{1}{|c|}{127.7} \\
\end{tabular} & \begin{tabular}{|l|} 
WARMRCY \\
RCYHEATR \\
HEATX \\
HEAPOR \\
VAPOR \\
\end{tabular} & $\begin{array}{l}\text { Display ALLS } \\
\text { Units: } \\
\text { Format: SOLI } \\
\text { Temperature } \\
\end{array}$ & $\begin{array}{l}\text { TREAMS } \\
\text { From } \\
\text { DS To } \\
\text { Phas } \\
\text { [C] } \\
\end{array}$ \\
\hline \begin{tabular}{|l} 
Pressure \\
\end{tabular} & {$[\mathrm{PSI}]$} & 279.4 & 265.9 & $\begin{array}{r}279.4 \\
\end{array}$ & 279.4 & $4 \quad 272.9$ & 274.9 & $\begin{array}{ll}14.7 \\
\end{array}$ & 265.9 & \begin{tabular}{l|l}
9 & 14.7 \\
\end{tabular} & $\begin{array}{ll}7 & 277.4 \\
\end{array}$ & Pressure & {$[\mathrm{PSI}]$} \\
\hline Mass VFrac & & 1 & 0 & 1 & 1 & 1 & 0 & 0 & 1 & 1 & 1 & Mass VFrac & \\
\hline Mass SFrac & & 0 & 0 & 0 & 0 & 0 & 1 & 0 & 0 & 0 & 0 & Mass SFrac & \\
\hline${ }^{* \star \star}$ ALL PHAS & $E S^{* \star *}$ & & & & & & & & & & & ${ }^{* \star *}$ ALL PHAS & $E S^{* \star *}$ \\
\hline Mass Flow & [LB/HR] & 49.58 & 1645.675 & 20010.68 & 20060.26 & 21656.5 & 48625.977 & 1596.094 & 20010.973 & 49.58 & 21199.451 & Mass Flow & {$[\mathrm{LB} / \mathrm{HR}]$} \\
\hline Volume Flow & [CUFT/HR] & 41.161 & 9.405 & 8070.953 & 8115.582 & 12934.794 & 232.279 & 8.823 & 8375.842 & 404.953 & 11828.04 & Volume Flow & [CUFT/HR] \\
\hline Enthalpy & {$[\mathrm{BTU} / \mathrm{HR}]$} & $-9.14 \mathrm{E}+04$ & 34663.465 & $-3.93 \mathrm{E}+07$ & -39425000 & $-3.78 \mathrm{E}+07$ & $-3.04 \mathrm{E}+08$ & $\begin{array}{l}131964.156 \\
\end{array}$ & -39363000 & -97300.727 & -38619000 & Enthalpy & {$[\mathrm{BTU} / \mathrm{HR}]$} \\
\hline \begin{tabular}{|l|l} 
Density \\
\end{tabular} & [LB/CUFT] & 1.205 & 174.979 & 2.479 & $\begin{array}{r}2.472 \\
\end{array}$ & 1.674 & 209.343 & 180.904 & 2.389 & 0.122 & $\begin{array}{r}1.792 \\
\end{array}$ & Density & [LB/CUFT] \\
\hline Mass Flow & {$[\mathrm{LB} / \mathrm{HR}]$} & & & & & & & & & & & Mass Flow & {$[\mathrm{LB} / \mathrm{HR}]$} \\
\hline O2S & & 49.553 & 52.704 & 20008.838 & 20058.391 & 20061.83 & & 3.15 & 20009.131 & 49.553 & 20002.434 & O2S & \\
\hline $\mathrm{H} 2 \mathrm{~S}$ & & & & & & & & & & & & $\mathrm{H} 2 \mathrm{~S}$ & \\
\hline $\mathrm{H} 2 \mathrm{O}$ & & & & & & & & & & & & $\mathrm{H} 2 \mathrm{O}$ & \\
\hline S2 & & & & & & 164.784 & & & & & & S2 & \\
\hline 56 & & 0.01 & 614.651 & 0.711 & 0.721 & 612.014 & & 614.641 & 0.711 & 0.01 & 0.719 & 56 & \\
\hline 58 & & 0.016 & 978.32 & 1.131 & 1.148 & 817.872 & & 978.303 & 1.131 & 0.016 & 1.144 & 58 & \\
\hline $\mathrm{CO}$ & & & & & & & & & & & & $\mathrm{CO}$ & \\
\hline $\mathrm{CO} 2$ & & & & & & & & & & & & $\mathrm{CO} 2$ & \\
\hline $\mathrm{H} 2$ & & & & & & & & & & & & $\mathrm{H} 2$ & \\
\hline $\mathrm{O} 2$ & & & & & & & & & & & 1195.155 & $\mathrm{O} 2$ & \\
\hline N2 & & & & & & & & & & & & N2 & \\
\hline $\cos$ & & & & & & & & & & & & $\cos$ & \\
\hline ZNO & & & & & & & & & & & & ZNO & \\
\hline ZNS & & & & & & & 717.431 & & & & & ZNS & \\
\hline $\mathrm{FE} 2 \mathrm{O} 3$ & & & & & & & & & & & & FE2O3 & \\
\hline FEO & & & & & & & & & & & & FEO & \\
\hline FES & & & & & & & 3908.545 & & & & & FES & \\
\hline AL2O3 & & & & & & & 44000 & & & & & AL2O3 & \\
\hline
\end{tabular}




\section{Appendix F \\ Steam Generation Process Flowsheets}

The following flowsheets represent possible design schemes for producing high pressure steam. Desulfurization units that require heat removal are utilized for producing the steam. The steam generated will result in an economic credit for the process. The steam generation simulations will help determine the equipment necessary for cooling the desulfurization process. 


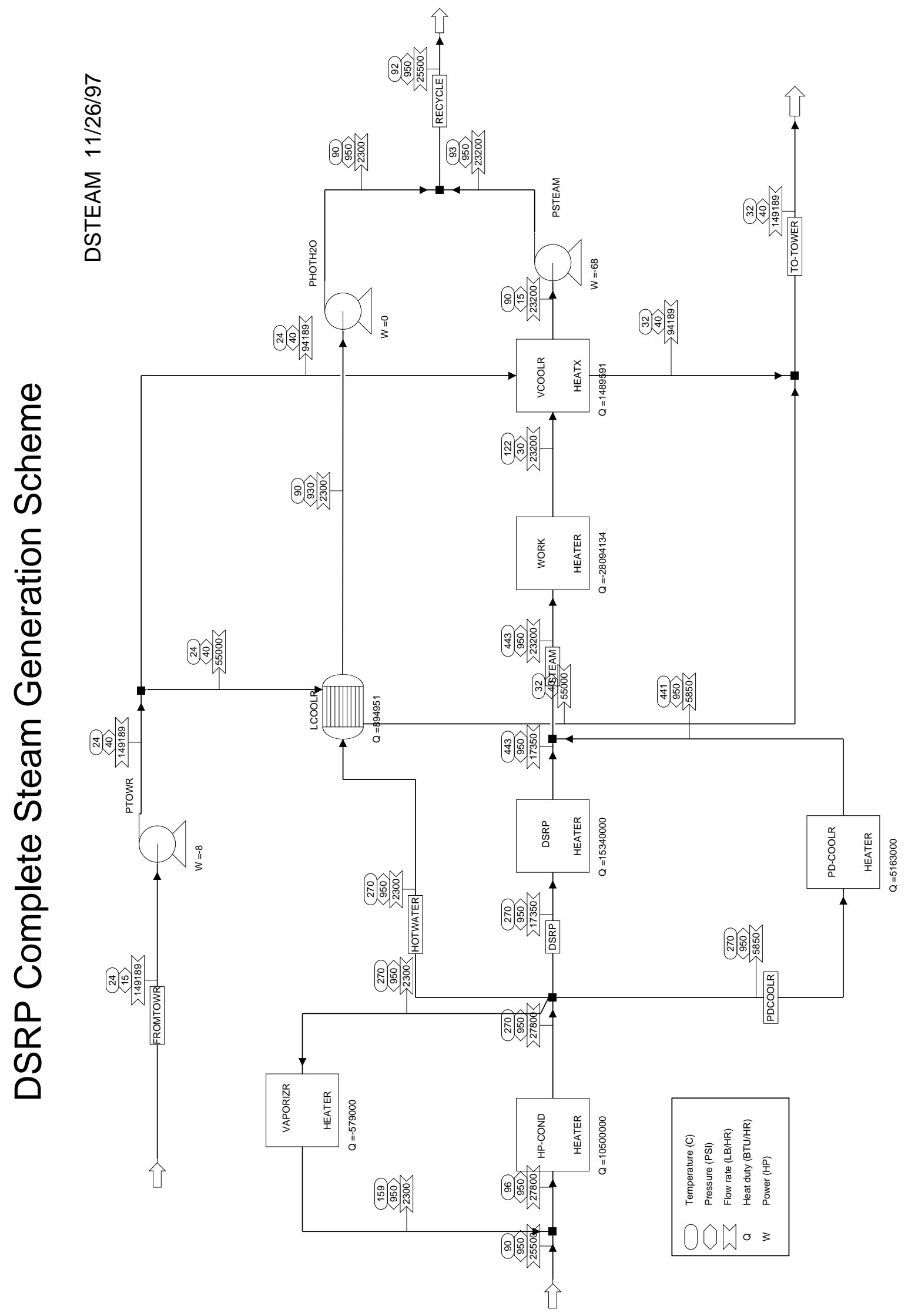




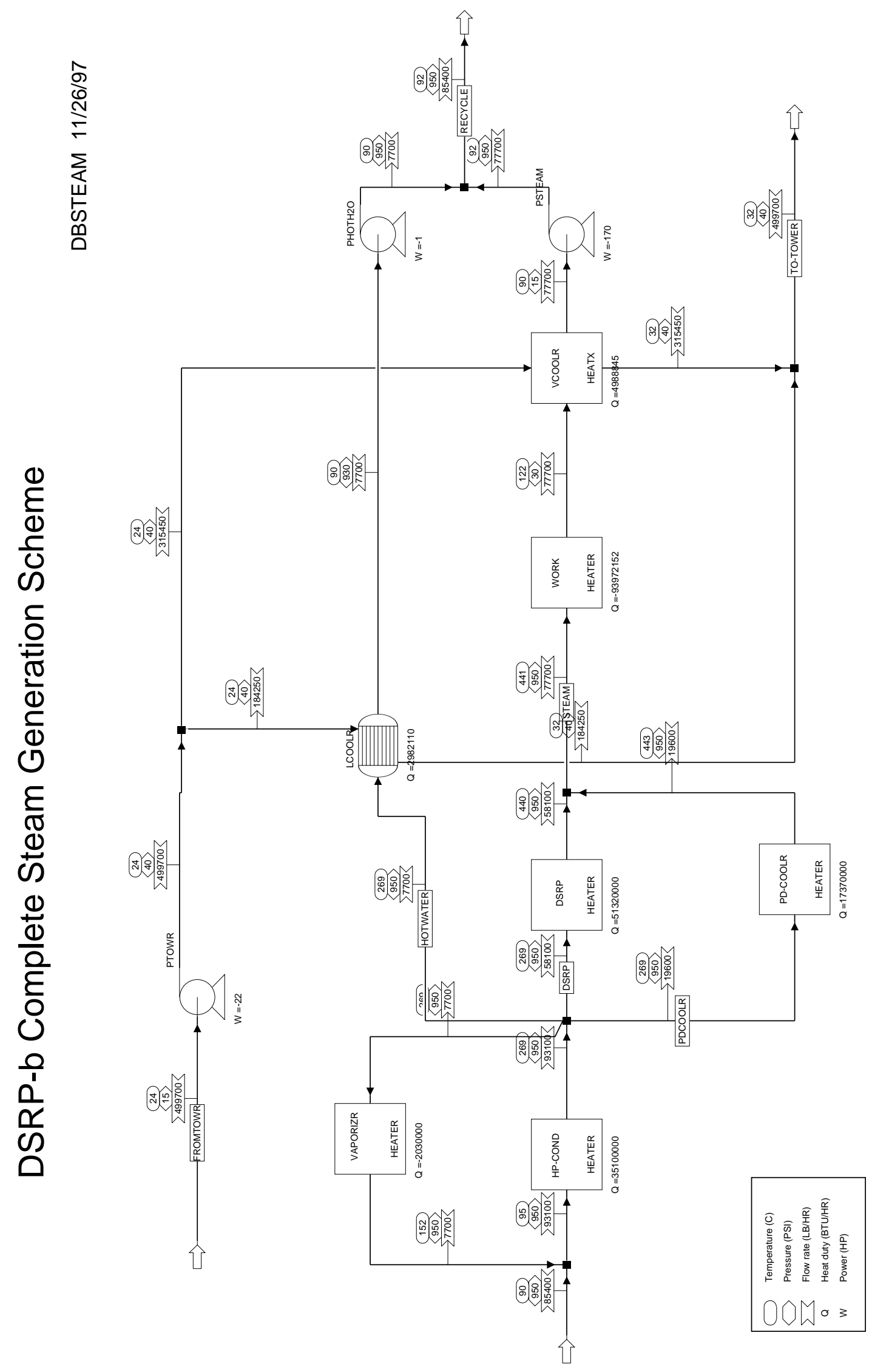




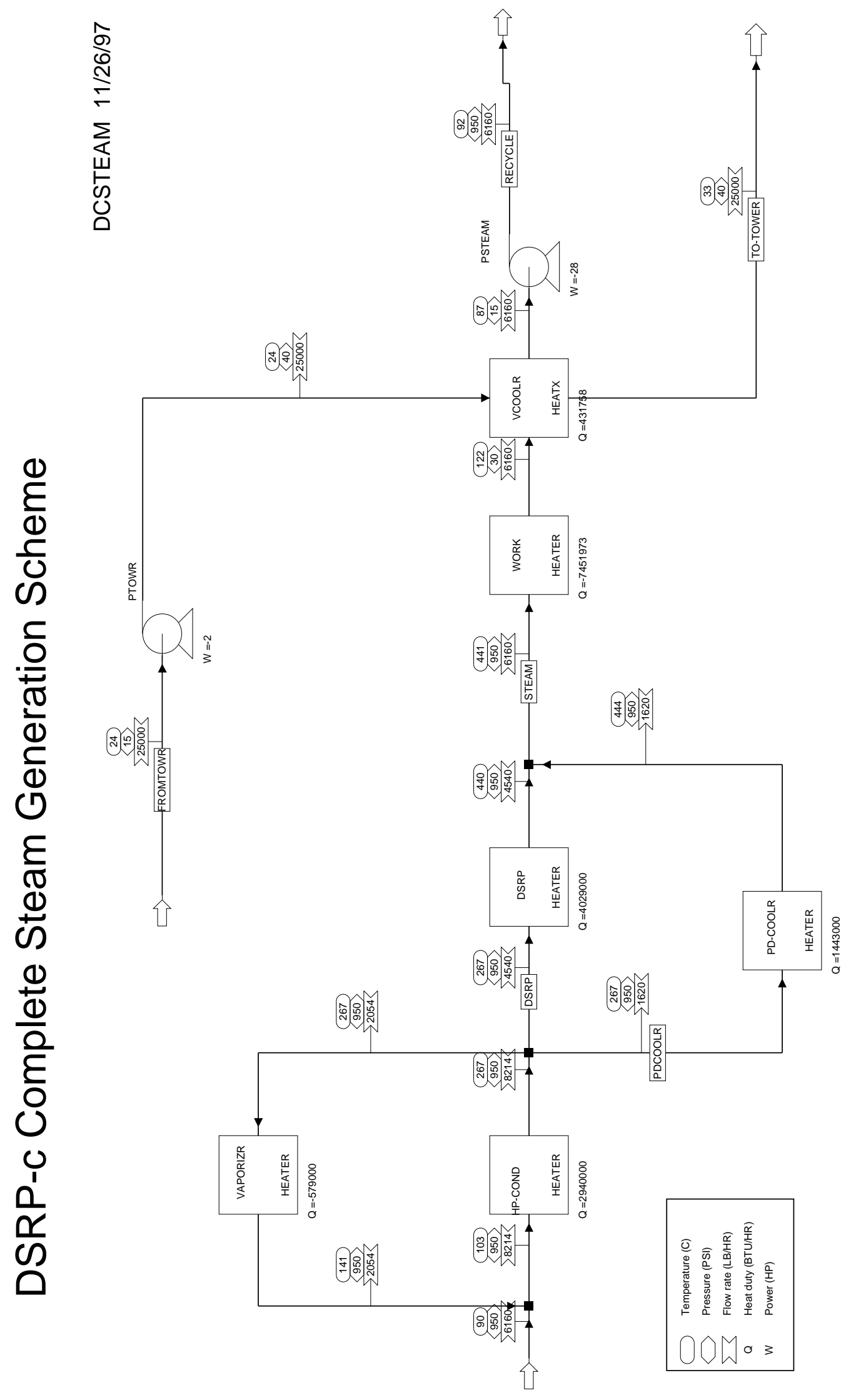




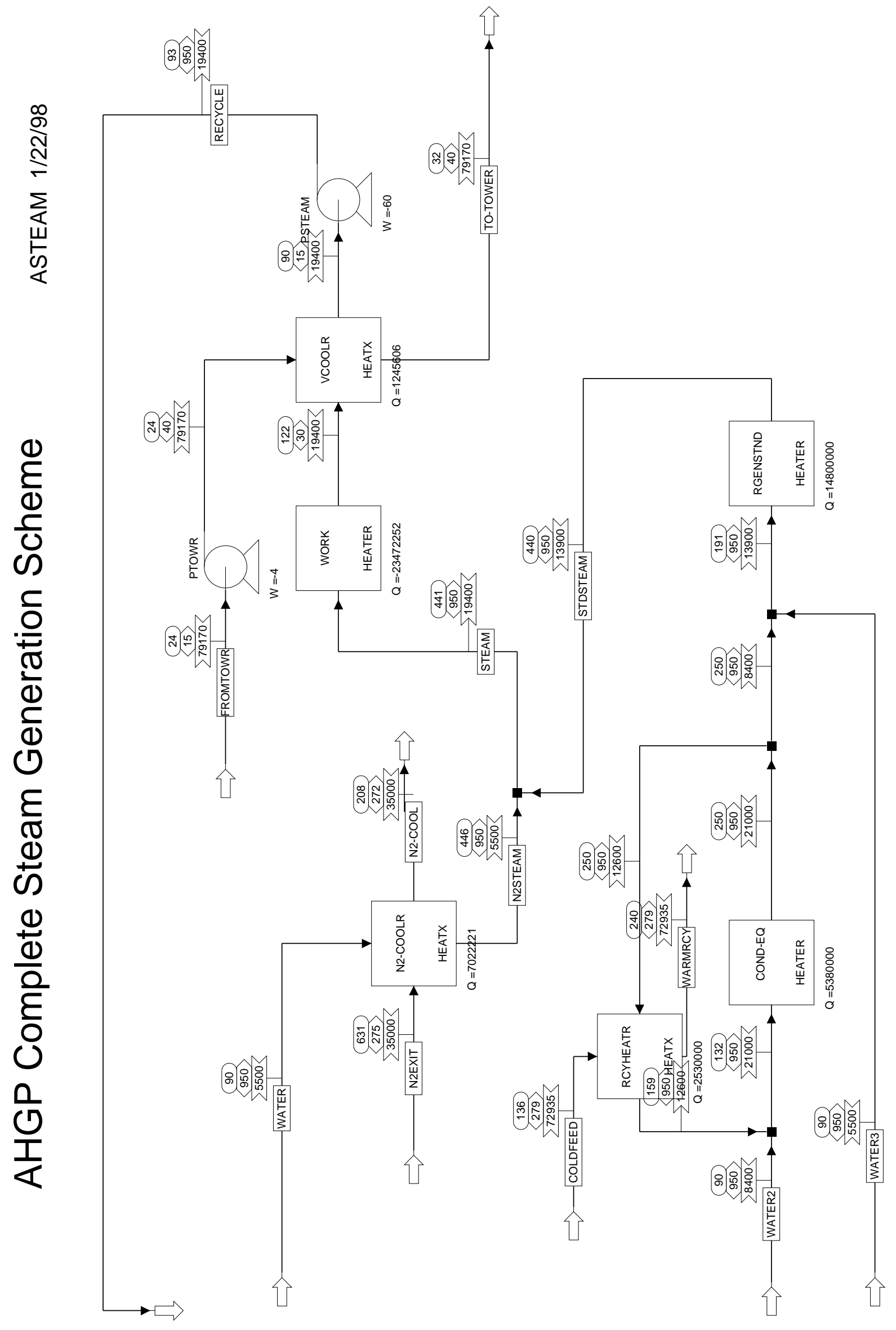




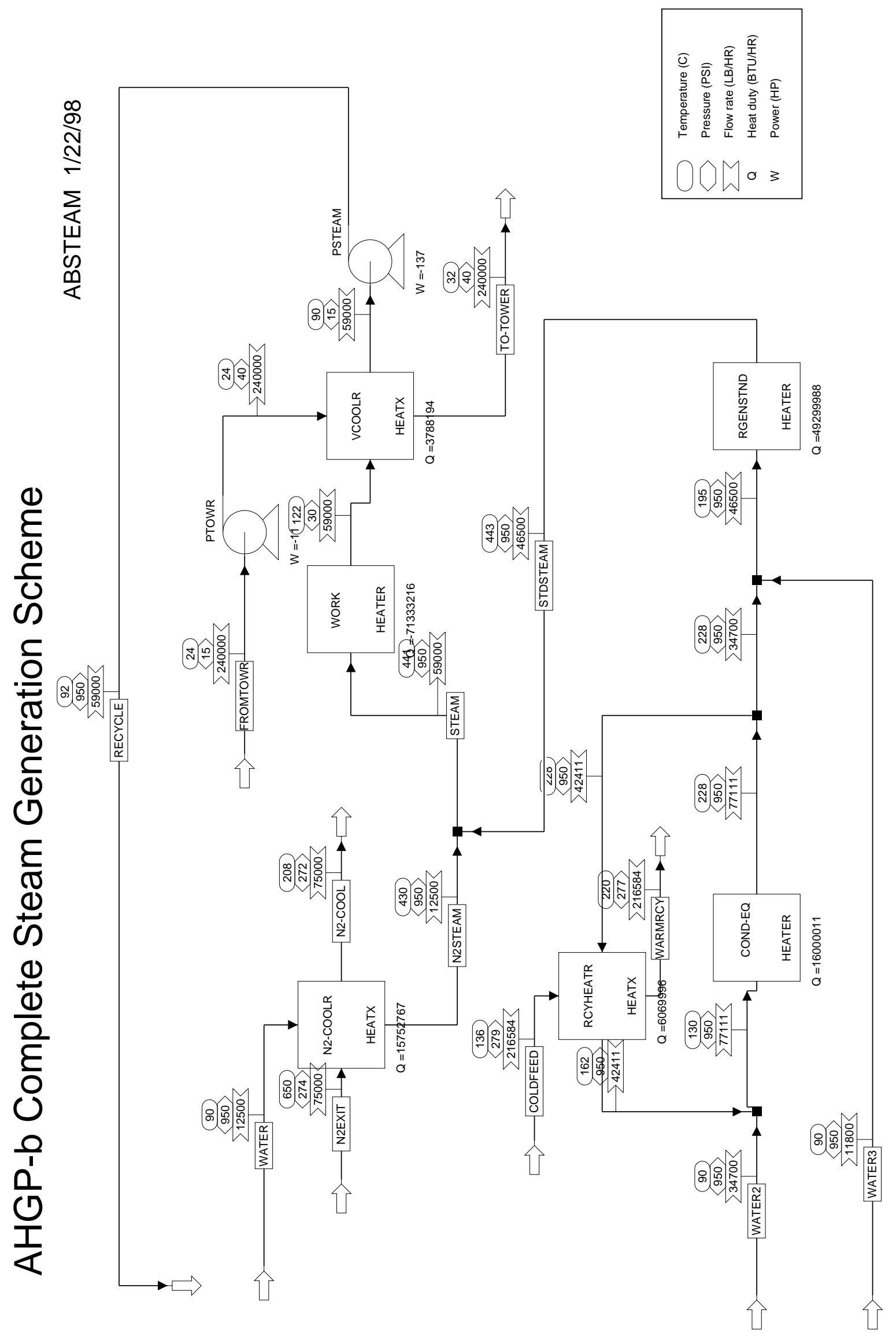




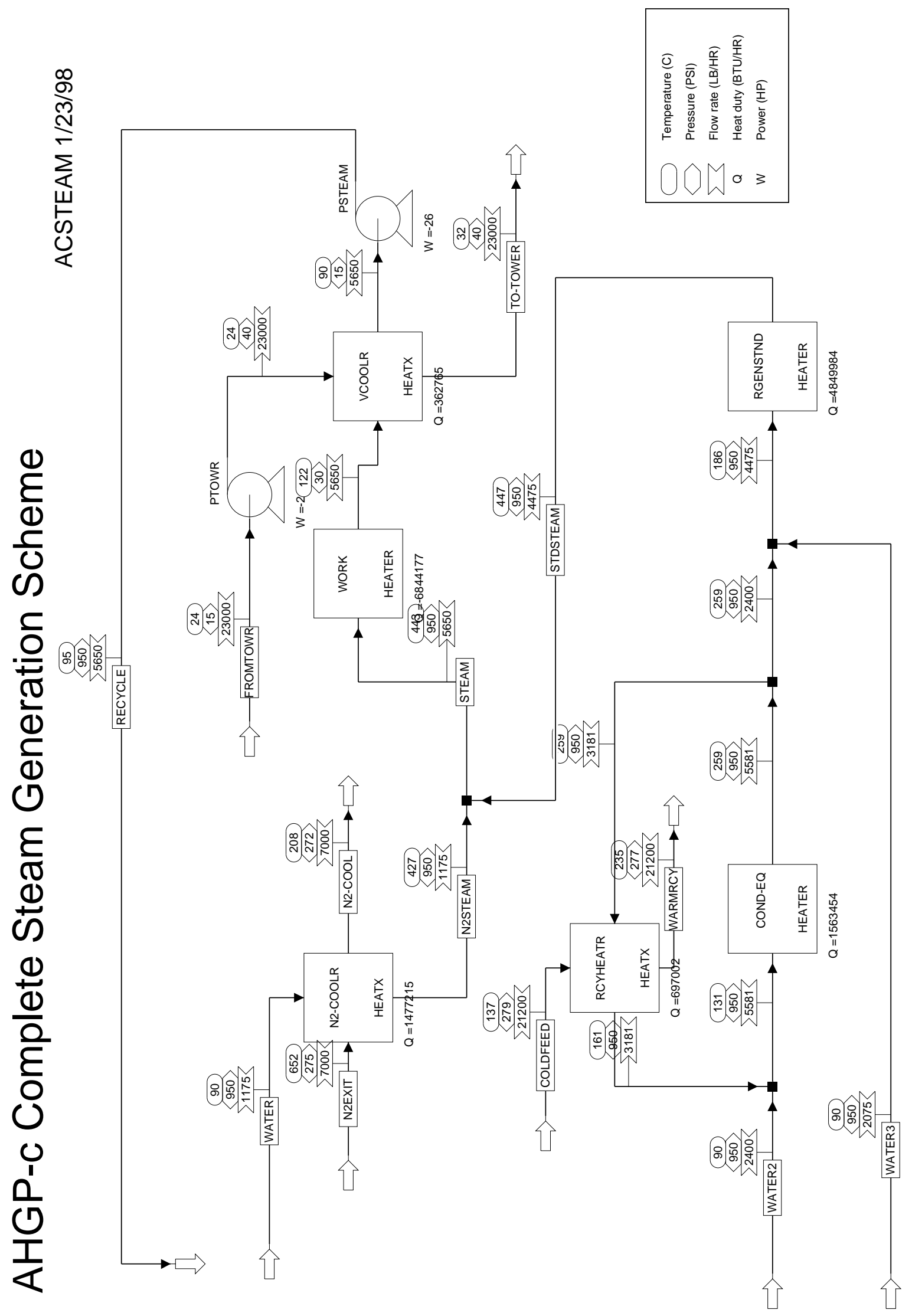


Appendix G

\section{Calculation of Reactor Size}

The reactor's diameter is determined from the average volumetric flow rate and the linear velocity.

$$
\begin{aligned}
& \mathrm{v}=20 \mathrm{ft} / \mathrm{sec}=72,000 \mathrm{ft} / \mathrm{hr} \\
& \mathrm{V}=[(\text { gas volume entering })+(\text { gas volume leaving })] / 2+(\text { sorbent mass flow })\left(60 \mathrm{lb} / \mathrm{ft}^{3}\right)^{-1} \\
& \text { Area }=\mathrm{V} / \mathrm{v}=\left(\text { Volumetric flow rate } \mathrm{ft}^{3} / \mathrm{hr}\right) / 72,000 \mathrm{ft} / \mathrm{hr} \quad\left\{\mathrm{ft}^{2}\right\}
\end{aligned}
$$

Calculating the area allows for the calculation of the reactor inside diameter.

$$
\begin{aligned}
& \text { Area }=\pi(\text { I.D. })^{2} /\left(4 \times 144 \mathrm{in}^{2} / \mathrm{ft}^{2}\right) \\
& \text { I.D. }=[(\text { Area })(4 \times 144) / \pi]^{0.5} \quad\{\text { in }\}
\end{aligned}
$$

The reactor cost will be based on the material of construction costs. The reactor wall thickness and height are necessary for such a calculation. The reactor system cost will be calculated to include installation costs.

The reactor will be cylindrical. The wall and heads will be assumed to have the same thickness. The following equation was used for determining wall thickness (Peters \& Timmerhaus, 1991).

Thickness $=\mathrm{P}(\mathrm{I} . \mathrm{D}) /.[2$ (Max. allowable working stress psia) $($ Efficiency of joints $)-0.6 \mathrm{P}]+\mathrm{C}_{\mathrm{c}}$

$$
\mathrm{P}=\text { pressure }\{\text { psia }\} \quad \mathrm{C}_{\mathrm{c}}=\text { corrosion losses }\{\text { in }\}
$$

$$
\text { Thickness }=275(\text { I.D. }) /[2(12,000)(0.85)-0.6(275)]+0.125
$$

Taking steel density to be $489 \mathrm{lb} / \mathrm{ft}^{3}$, the reactor weight is calculated with the equations below.

$$
\begin{array}{ll}
\text { Weight of shell }=\pi \text { (I.D./12) } \text { (height) }(\text { Thickness/12)(489) } & \{\text { lbs }\} \\
\text { Weight of heads }=2 \pi[12 \text { I.D./ } 2]^{2} \text { (Thickness) }\left(489 / 12^{3}\right)(2) & \{l b s\} \\
\text { Total weight }=1.15 \text { (weight of shell + weight of heads) } & \{l b s\}
\end{array}
$$

The total weight is increased $15 \%$ to account of nozzles, manholes, ect.

The cost of carbon steel can be calculated by the equation below. 


$$
(\text { Cost per } \mathrm{lb})=80(\text { total weight })^{-0.34}
$$

The equation above in applicable for $800 \mathrm{lb}$ to $100,000 \mathrm{lb}$ vessels (Peters and Timmerhaus 1991). Estimates for weights over 100,000 lbs could not be found. Therefore, in such cases the unit cost for carbon steel was taken as an average of the above equation calculated for 100,000 lb and the above equation calculated for the total weight. The unit cost is expected to continue to decrease at larger quantities but the decrease should become less pronounced.

Unit cost of carbon steel (weight > 100,000 lbs)

$$
(\text { Cost per lb })=80\left[(\text { total weight })^{-0.34}+(100,000)^{-0.34}\right] / 2
$$

The cost of installation will be twice of the cost of the reactor if it were constructed of carbon steel.

$($ Cost of installation $)=2($ Cost per lb) $($ total weight $)$

The total cost of the reactor system includes installation and material costs. Material cost is multiplied by 3.5 to account for using stainless steel 310 instead of carbon steel.

$($ Total cost for reactor $)=($ Cost of installation $)+3.5($ Cost per $l b)($ total weight $)$ 


\section{Appendix H \\ Sizing Reactors for the DSRP}

Copies of the reactor system sizing calculations follow. They include estimates of the reactor system costs. The equations describe in Appendix $G$ - Calculation of Reactor Size where used in the spreadsheet. 
DSRP reactor

\title{
DSRP Reactor Cost
}

DSRP

DSRP Reactor

$\mathrm{v}$ (ft/sec) gas =

$\mathrm{V}(\mathrm{cfh})=$

space time -gas

$\mathrm{v}(\mathrm{ft} / \mathrm{sec}) \mathrm{cat}=$

Area $=$

I.D.

thickness=

shell wt. $=$

heads wt. $=$

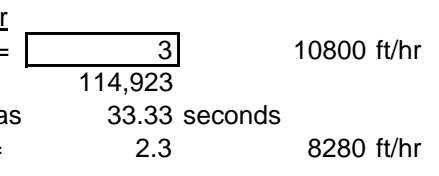

$10.782 \mathrm{ft}^{\wedge} 2$

45.391 in

0.742 in

$35,930 \mathrm{lbs}$

$1,359 \mathrm{lbs}$

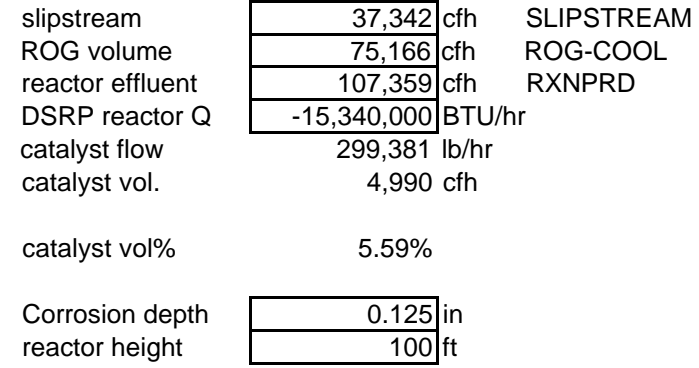

total wt.

42,882 lbs (includes additional 15\% for nozzles, manholes, etc.)

DSRP Standpipe

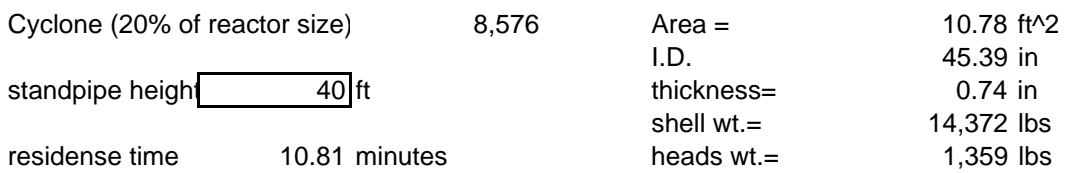

total wt.

26,667 lbs (includes additional $15 \%$ on standpipe weight + Cyclone weight)

Heat Exchanger

Heat Exchanger Area ( $\left.\mathrm{ft}^{\wedge} 2\right)$

1063

heat exchanger pipe thickness

0.25 in

volume of stee

22

total weight

$10,829 \mathrm{lbs}$

total wt.

80,379 Ibs

weight for DSRP reactor system

$\underline{\text { COST }}$

C.S. unit price for quantiy needed

$\begin{array}{ll}1.719 \$ / \mathrm{lb} & 1990 \$ \\ 1.837 \$ / \mathrm{lb} & 1996 \$\end{array}$

\author{
$>100,000 \mathrm{lb}$ calc \\ 1.6577359551 .719 \\ $<100,000 \mathrm{lb}$ calc
}

Cost of installation

$\$ 295,320$

Total reactor cost

$\$ \mathbf{8 1 2 , 1 2 9}$ includes cost of installation 
reactors DSRP-b

DSRP

Desulf and Regen transport reactor price calculation

Regenerator Reactor

$\mathrm{v}(\mathrm{ft} / \mathrm{sec})=\quad 20$

$\mathrm{V}(\mathrm{cfh})=277,458$

Area $=\quad 3.854 \mathrm{ft}^{\wedge} 2$

I.D. 27.137 in

thickness $=\quad 0.494$

shell wt. $=\quad 14,298 \mathrm{lbs}$

$72000 \mathrm{ft} / \mathrm{hr}$

air volume

ROG volume

regen sorbent flow

regen sorbent vol.

\begin{tabular}{|r|ll}
\hline 215,340 & cfh & HP-O2-N2 \\
\hline 299,541 & cfh & ROG \\
\cline { 1 - 2 } $1,201,050$ & $\mathrm{lb} / \mathrm{hr}$ & ZNS2RGEN \\
\hline 20,018 & $\mathrm{cfh}$ &
\end{tabular}

sorbent vol\%

$7.21 \%$

heads wt. $\quad 323 \mathrm{lbs}$

Corrosion depth $\quad 0.125$ in

reactor height

$100 \mathrm{ft}$

total wt.

16,814 lbs (includes additional 15\% for nozzles, manholes, etc.)

$\underline{\text { Regenerator Standpipe }}$

total wt.

$16,814 \mathrm{lbs}$

size vs. regen size

1

Desulfurization Reactor

$\begin{array}{lr}\mathrm{v}(\mathrm{ft} / \mathrm{sec})= & 20 \\ \mathrm{~V}(\mathrm{cfh})= & 1,687,918\end{array}$

$72000 \mathrm{ft} / \mathrm{hr}$

Area $=\quad 23.443 \mathrm{ft}^{\wedge} 2$

I.D. $\quad 66.933$ in

thickness $=\quad 1.035$

shell wt. $=\quad 73,889 \mathrm{lbs}$

heads wt. $=4,121 \mathrm{lbs}$

coal gas in volume $1,409,220 \mathrm{cfh}$ RAW-CG

\begin{tabular}{l|r|} 
cg out volume & $1,877,650 \mathrm{cfh} \quad \mathrm{CG}-\mathrm{CALC}$
\end{tabular}

regen sorbent flow $2,669,000 \mathrm{lb} / \mathrm{hr}$ ZNS

regen sorbent vol. $\quad 44,483 \mathrm{cfh}$

sorbent vol\% $\quad 2.64 \%$

Corrosion depth $\quad 0.125$ in

reactor height

$100 \mathrm{ft}$

total wt.

89,711 lbs (includes additional 15\% for nozzles, manholes, etc.)

Desulfurization Standpipe

total wt.

$89,711 \mathrm{lbs}$

size vs. desulf size 1

total wt. $213,051 \mathrm{lbs} \quad$ weight for desulfurization and regeneration transport reactors

$\underline{\text { COST }}$

C.S. unit price for quantiy needed

$1.415 \$ / \mathrm{lb}$

$1990 \$$

$1.512 \$ / l b \quad 1996 \$$

$>100,000 \mathrm{lb}$ calc

1.41523351 .234

$<100,000 \mathrm{lb}$ calc

Cost of installation

$\$ 644,349$

Total reactor cost

$\$ 1,771,959$ includes cost of installation 


\section{DSRP-b reactor}

DSRP

DSRP Reactor

$\mathrm{v}(\mathrm{ft} / \mathrm{sec})$ gas $=$

$\mathrm{V}(\mathrm{cfh})=$

space time -gas

$\mathrm{v}(\mathrm{ft} / \mathrm{sec}) \mathrm{cat}=$

Area $=$

I.D.

thickness $=$

shell wt.=

heads wt. $=$

\section{DSRP-b Reactor Cost}

\begin{tabular}{|c|c|c|c|c|}
\hline & \multirow[b]{2}{*}{$10800 \mathrm{ft} / \mathrm{hr}$} & \multirow{3}{*}{$\begin{array}{l}\text { slipstream } \\
\text { ROG volume } \\
\text { reactor effluent }\end{array}$} & $153708 \mathrm{ch}$ & SUIPSTREAM \\
\hline 3 & & & 237,184 cfh & ROG-COOL \\
\hline 393,089 & & & 361,900 cfh & RXNPRD \\
\hline 33.33 seconds & & DSRP reactor $Q$ & $-51,320,000$ BTU/hr & \\
\hline 2.3 & $8280 \mathrm{ft} / \mathrm{hr}$ & $\begin{array}{l}\text { catalyst flow } \\
\text { catalyst vol. }\end{array}$ & $\begin{array}{c}1,001,581 \mathrm{lb} / \mathrm{hr} \\
16,693 \mathrm{cfh}\end{array}$ & \\
\hline $36.868 \mathrm{ft}^{\wedge} 2$ & & & & \\
\hline $\begin{array}{r}83.936 \text { in } \\
1.266 \text { in }\end{array}$ & & catalyst vol\% & $5.47 \%$ & \\
\hline 113,355 lbs & & Corrosion depth & 0.125 in & \\
\hline 7,929 lbs & & reactor height & $100 \mathrm{ft}$ & \\
\hline
\end{tabular}

total wt.

139,477 lbs (includes additional 15\% for nozzles, manholes, etc.)

DSRP Standpipe

\begin{tabular}{lllr} 
Cyclone (20\% of reactor size) & 27,895 & Area $=$ & $36.87 \mathrm{ft}^{\wedge} 2$ \\
& & I.D. & $83.94 \mathrm{in}$ \\
standpipe heighh & thickness $=$ & $1.27 \mathrm{in}$ \\
& & shell wt. & $45,342 \mathrm{lbs}$ \\
residense time & \multirow{2}{*}{11.05 minutes } & heads wt. $=$ & $7,929 \mathrm{lbs}$
\end{tabular}

total wt.

89,157 Ibs (includes additional $15 \%$ on standpipe weight + Cyclone weight)

Heat Exchanger

Heat Exchanger Area ( $\left.\mathrm{ft}^{\wedge} 2\right)$

3556

heat exchanger pipe thickness 0.25 in

volume of steel

74

total weight

36,229 lbs

total wt.

264,863 lbs

weight for DSRP reactor system

$\underline{\mathrm{COST}}$

C.S. unit price for quantiy needed

$1.371 \$ / \mathrm{lb} \quad 1990 \$$

1.465 \$/lb $\quad 1996 \$$
$>100,000 \mathrm{lb}$ calc 1.3712081081 .146
$<100,000 \mathrm{lb}$ calc

Cost of installation

$\$ 776,129$

Total reactor cost

$\$ 2,134,355$ includes cost of installation 
reactors DSRP-C

DSRP

Desulf and Regen transport reactor price calculation

Regenerator Reactor

$\mathrm{v}(\mathrm{ft} / \mathrm{sec})=20$

$\mathrm{V}(\mathrm{cfh})=\quad 23,882$

Area $=\quad 0.332 \mathrm{ft}^{\wedge} 2$

I.D. $\quad 7.962$ in

thickness $=\quad 0.233$

shell wt. $=\quad 1,981 \mathrm{lbs}$

$72000 \mathrm{ft} / \mathrm{hr}$

air volume

ROG volume

regen sorbent flow

19,366 cfh

HP-O2-N2

regen sorbent vol.

heads wt. $=$

$13 \mathrm{lbs}$

sorbent vol\%

$71,663 \mathrm{lb} / \mathrm{hr}$ ZNS2RGEN

total wt.

2,293 lbs (includes additional 15\% for nozzles, manholes, etc.)

$\underline{\text { Regenerator Standpipe }}$

total wt.

2,293 lbs

Corrosion depth

reactor height

$1,194 \mathrm{cfh}$

$100 \mathrm{ft}$

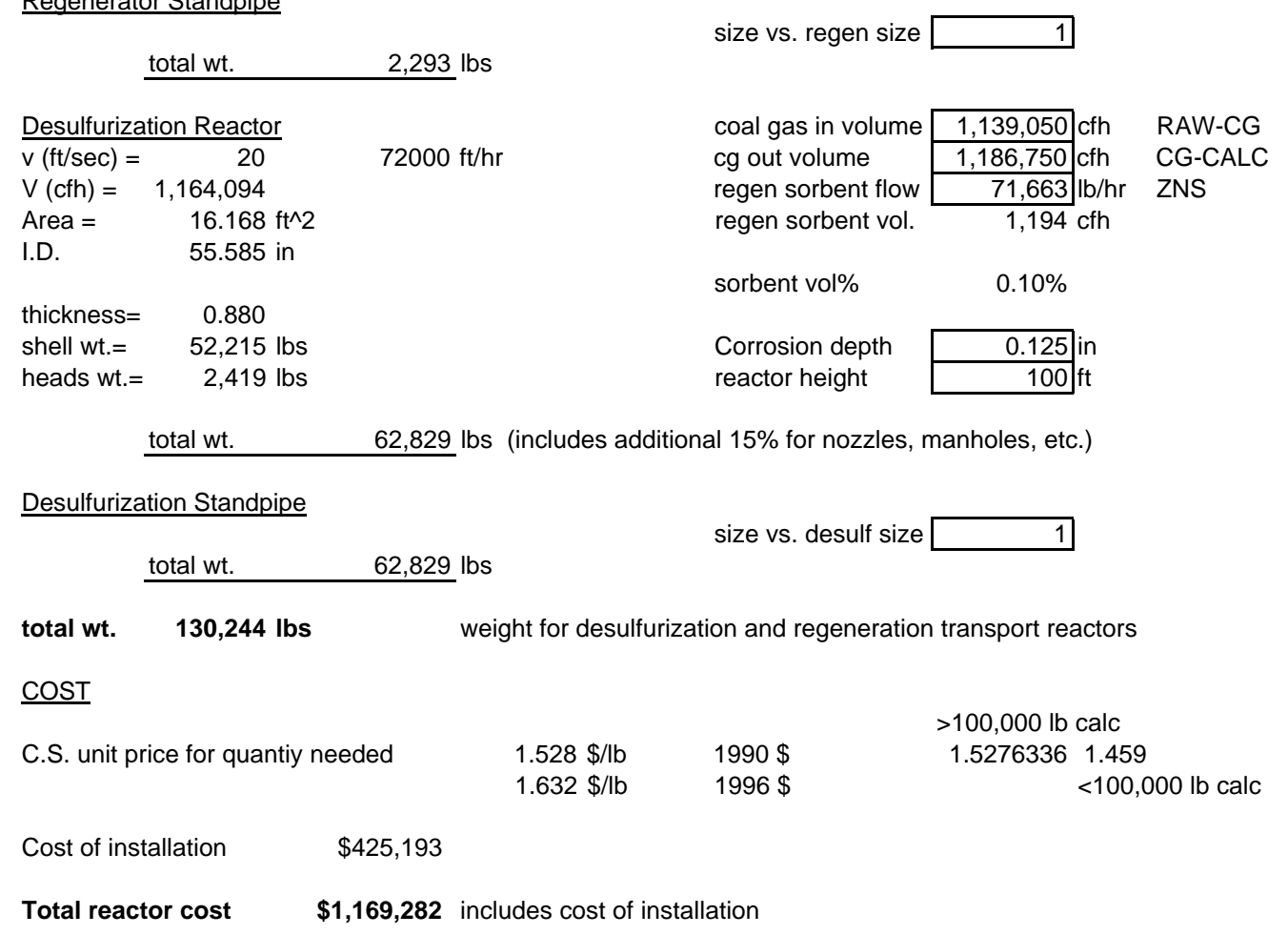




\section{DSRP-c reactor}

\section{DSRP-c Reactor Cost}

DSRP

DSRP Reactor

$\mathrm{v}(\mathrm{ft} / \mathrm{sec})$ gas $=$

$\mathrm{V}(\mathrm{cfh})=$

space time -gas

$\mathrm{v}(\mathrm{ft} / \mathrm{sec}) \mathrm{cat}=$

Area $=$

I.D.

thickness $=$

shell wt.=

heads wt. $=$

\begin{tabular}{|cr}
\hline 3 & $10800 \mathrm{ft} / \mathrm{hr}$ \\
31,212 & \\
33.33 seconds & \\
2.3 & $8280 \mathrm{ft} / \mathrm{hr}$ \\
& \\
$2.93 \mathrm{ft}^{\wedge} 2$ & \\
$23.650 \mathrm{in}$ & \\
0.446 & in \\
$11,265 \mathrm{lbs}$ & \\
$222 \mathrm{lbs}$ &
\end{tabular}

\begin{tabular}{|c|c|c|}
\hline \multirow{4}{*}{$\begin{array}{l}\text { slipstream } \\
\text { ROG volume } \\
\text { reactor effluent } \\
\text { DSRP reactor Q } \\
\text { catalyst flow } \\
\text { catalyst vol. }\end{array}$} & 9,443 cfh & \multirow{4}{*}{$\begin{array}{l}\text { SLIPSTREAM } \\
\text { ROG-COOL } \\
\text { RXNPRD }\end{array}$} \\
\hline & $20,364 \mathrm{cfh}$ & \\
\hline & 29,995 cfh & \\
\hline & $\begin{array}{c}-4,029,000 \mathrm{BTU} / \mathrm{h} \\
78,632 \mathrm{lb} / \mathrm{hr} \\
1,311 \mathrm{cfh}\end{array}$ & \\
\hline catalyst vol\% & $5.41 \%$ & \\
\hline $\begin{array}{l}\text { Corrosion depth } \\
\text { reactor height }\end{array}$ & $\begin{array}{rl}0.125 & \text { in } \\
100 & \mathrm{ft} \\
\end{array}$ & \\
\hline
\end{tabular}

total wt.

13,210 lbs (includes additional 15\% for nozzles, manholes, etc.)

DSRP Standpipe

\begin{tabular}{lllr} 
Cyclone $(20 \%$ of reactor size $)$ & \multirow{2}{*}{2,642} & Area $=$ & $2.93 \mathrm{ft}^{\wedge} 2$ \\
& & I.D. & $23.65 \mathrm{in}$ \\
standpipe height & thickness $=$ & $0.45 \mathrm{in}$ \\
& & shell wt. $=$ & $4,506 \mathrm{lbs}$ \\
residense time & \multirow{2}{*}{11.17 minutes } & heads wt. $=$ & $222 \mathrm{lbs}$
\end{tabular}

total wt.

8,079 lbs (includes additional $15 \%$ on standpipe weight + Cyclone weight)

Heat Exchanger

Heat Exchanger Area ( $\left(\mathrm{ft}^{\wedge} 2\right)$

279

heat exchanger pipe thickness 0.25 in

volume of steel

6

total weight

$2,844 \mathrm{lbs}$

total wt.

24,133 Ibs

weight for DSRP reactor system

$\underline{\mathrm{COST}}$

C.S. unit price for quantiy needed

$2.588 \$ / \mathrm{lb} \quad 1990 \$$

$2.766 \$ / \mathrm{lb} \quad 1996 \$$

$>100,000 \mathrm{lb}$ calc

2.0922185392 .588

$<100,000 \mathrm{lb}$ calc

Cost of installation

$\$ 133,482$

Total reactor cost

$\$ 367,075$ includes cost of installation 
reactors DSRP -100

\section{Desulf and Regen transport reactor price calculation}

DSRP

Regenerator Reactor

$\mathrm{v}(\mathrm{ft} / \mathrm{sec})=20$

$\mathrm{V}(\mathrm{cfh})=\quad 36,020$

$72000 \mathrm{ft} / \mathrm{hr}$

air volume

ROG volume

28,592 cfh HP-O2-N2

Area $=\quad 0.500 \mathrm{ft}^{\wedge} 2$

I.D. $\quad 9.778$ in

thickness $=\quad 0.258$

shell wt. $=2,690 \mathrm{lbs}$

regen sorbent flow

39,921 cfh ROG

regen sorbent vol.

$1,763 \mathrm{cfh}$

ZNS2RGEN

sorbent vol\%

$4.90 \%$

heads wt. $=$

22 lbs

Corrosion depth

reactor height

\subsection{5 in}

$100 \mathrm{ft}$

total wt.

3,119 lbs (includes additional 15\% for nozzles, manholes, etc.)

$\underline{\text { Regenerator Standpipe }}$

total wt.

3,119 lbs

size vs. regen size 1

Desulfurization Reactor

$\mathrm{v}(\mathrm{ft} / \mathrm{sec})=20$

$\mathrm{V}(\mathrm{cfh})=\quad 545,644$

Area $=\quad 7.58 \mathrm{ft}^{\wedge} 2$

I.D. $\quad 38.06$ in

thickness $=\quad 0.642$

shell wt. $=\quad 26,075 \mathrm{lbs}$

heads wt. $=\quad 827 \mathrm{lbs}$

$72000 \mathrm{ft} / \mathrm{hr}$

coal gas in volume

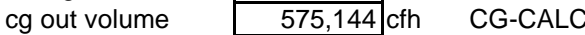

regen sorbent flow $281,971 \mathrm{lb} / \mathrm{hr}$ ZNS

regen sorbent vol. $\quad 4,700 \mathrm{cfh}$

sorbent vol\% $\quad 0.86 \%$

Corrosion depth $\quad 0.125$ in

reactor height

$100 \mathrm{ft}$

total wt.

30,938 lbs (includes additional 15\% for nozzles, manholes, etc.)

Desulfurization Standpipe

total wt.

$30,938 \mathrm{lbs}$

size vs. desulf size 1

total wt. $\quad 68,113$ Ibs weight for desulfurization and regeneration transport reactors

$\underline{\text { COST }}$

C.S. unit price for quantiy needed

$1.819 \$ / \mathrm{lb}$

$1990 \$$

$1.943 \$ / \mathrm{lb}$

$1996 \$$

$>100,000 \mathrm{lb}$ calc

$1.7075181 \quad 1.819$

$<100,000 \mathrm{lb}$ calc

Cost of installation

$\$ 264,748$

Total reactor cost

$\$ 728,057$ includes cost of installation 


\section{DSRP-100 reactor}

DSRP

DSRP-100 Reactor Cost

DSRP Reactor

$\mathrm{v}(\mathrm{ft} / \mathrm{sec}) \mathrm{gas}=$

$\mathrm{V}(\mathrm{cfh})=$

space time -gas

$\mathrm{v}(\mathrm{ft} / \mathrm{sec})$ cat $=$

Area $=$

I.D.

thickness=

shell wt.=

heads wt. $=$

\begin{tabular}{|cc}
\hline 3 & $10800 \mathrm{ft} / \mathrm{hr}$ \\
\hline 48,391 & \\
33.33 seconds & \\
2.3 & $8280 \mathrm{ft} / \mathrm{hr}$
\end{tabular}

$4.540 \mathrm{ft}^{\wedge} 2$

29.454 in

0.525 in

$16,508 \mathrm{lbs}$

405 lbs

\begin{tabular}{|c|c|c|}
\hline \multirow{6}{*}{$\begin{array}{l}\text { slipstream } \\
\text { ROG volume } \\
\text { reactor effluent } \\
\text { DSRP reactor Q } \\
\text { catalyst flow } \\
\text { catalyst vol. }\end{array}$} & 15,723 cfh & SLIPSTREAM \\
\hline & 31,647 cfh & ROG-COOL \\
\hline & 45,210 cfh & RXNPRD \\
\hline & \multirow{3}{*}{\multicolumn{2}{|c|}{$\begin{array}{c}-6,459,000 \mathrm{BTU} / \mathrm{hr} \\
126,056 \mathrm{lb} / \mathrm{hr} \\
2,101 \mathrm{cfh}\end{array}$}} \\
\hline & & \\
\hline & & \\
\hline catalyst vol\% & \multicolumn{2}{|l|}{$5.59 \%$} \\
\hline \multirow{2}{*}{$\begin{array}{l}\text { Corrosion depth } \\
\text { reactor height }\end{array}$} & \multicolumn{2}{|l|}{0.125 in } \\
\hline & $100 \mathrm{ft}$ & \\
\hline
\end{tabular}

total wt.

19,451 lbs (includes additional 15\% for nozzles, manholes, etc.)

DSRP Standpipe

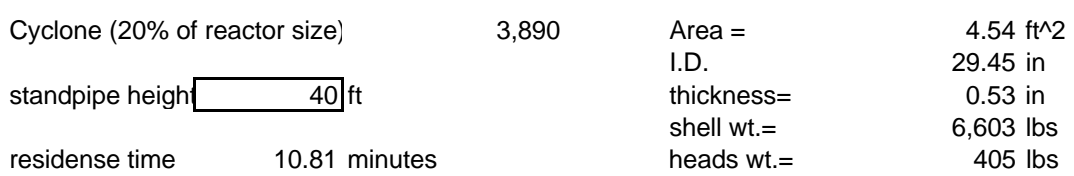

total wt.

11,950 lbs (includes additional 15\% on standpipe weight + Cyclone weight)

Heat Exchanger

Heat Exchanger Area (ft^2)

448

heat exchanger pipe thickness 0.25 in

volume of steel

9

total weight

$4,560 \mathrm{lbs}$

total wt.

35,960 lbs

weight for DSRP reactor system

$\underline{\mathrm{COST}}$

C.S. unit price for quantiy needed

$2.260 \$ / \mathrm{lb} \quad 1990 \$$

2.415 \$/lb $1996 \$$

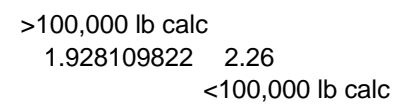

Cost of installation

$\$ 173,677$

Total reactor cost

$\$ 477,612$ includes cost of installation 
reactors DSRP -500

DSRP

\section{Desulf and Regen transport reactor price calculation}

Regenerator Reactor

$\mathrm{v}(\mathrm{ft} / \mathrm{sec})=20$

$\mathrm{V}(\mathrm{cfh})=\quad 176,007$

$72000 \mathrm{ft} / \mathrm{hr}$

air volume

ROG volume

139,951 cfh HP-O2-N2

regen sorbent flow

194,430 cfh ROG

Area $=\quad 2.445 \mathrm{ft}^{\wedge} 2$

I.D. 21.614 in

regen sorbent vol.

$528,985 \mathrm{lb} / \mathrm{hr}$ ZNS2RGEN

sorbent vol\%

$5.01 \%$

thickness $=\quad 0.419$

shell wt. $=\quad 9,656 \mathrm{lbs}$

Corrosion depth 0.125 in

heads wt. $=174 \mathrm{lbs}$

reactor height

$100 \mathrm{ft}$

total wt.

11,305 lbs (includes additional 15\% for nozzles, manholes, etc.)

$\underline{\text { Regenerator Standpipe }}$

total wt.

$11,305 \mathrm{lbs}$

size vs. regen size 1

Desulfurization Reactor

$\mathrm{v}(\mathrm{ft} / \mathrm{sec})=\quad 20$

$\mathrm{V}(\mathrm{cfh})=2,722,971$

Area $=\quad 37.82 \mathrm{ft}^{\wedge} 2$

I.D. $\quad 85.01$ in

thickness $=1.280348$

shell wt. $=116,135 \mathrm{lbs}$

heads wt. $=\quad 8,227 \mathrm{lbs}$

$72000 \mathrm{ft} / \mathrm{hr}$

coal gas in volume

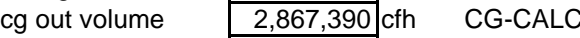

RAW-CG

regen sorbent vol. $23,511 \mathrm{cfh}$

ZNS

sorbent vol\% $\quad 0.86 \%$

Corrosion depth $\quad 0.125$ in

reactor height

$100 \mathrm{ft}$

total wt.

143,017 lbs (includes additional 15\% for nozzles, manholes, etc.)

Desulfurization Standpipe

total wt.

$143,017 \mathrm{lbs}$

size vs. desulf size 1

total wt. $\quad 308,644 \mathrm{lbs} \quad$ weight for desulfurization and regeneration transport reactors

$\underline{\text { COST }}$

C.S. unit price for quantiy needed

$1.342 \$ / \mathrm{lb}$

$1990 \$$

$1.434 \$ / l b \quad 1996 \$$

$>100,000 \mathrm{lb}$ calc

1.34216171 .088

$<100,000 \mathrm{lb}$ calc

Cost of installation

$\$ 885,263$

Total reactor cost

$\$ \mathbf{2 , 4 3 4 , 4 7 4}$ includes cost of installation 


\section{DSRP-500 reactor}

DSRP

DSRP Reactor

$\mathrm{v}(\mathrm{ft} / \mathrm{sec}) \mathrm{gas}=$

$\mathrm{V}(\mathrm{cfh})=$

space time -gas

$\mathrm{v}(\mathrm{ft} / \mathrm{sec}) \mathrm{cat}=$

Area $=$

I.D.

thickness $=$

shell wt.=

heads wt. $=$

\section{DSRP-500 Reactor Cost}

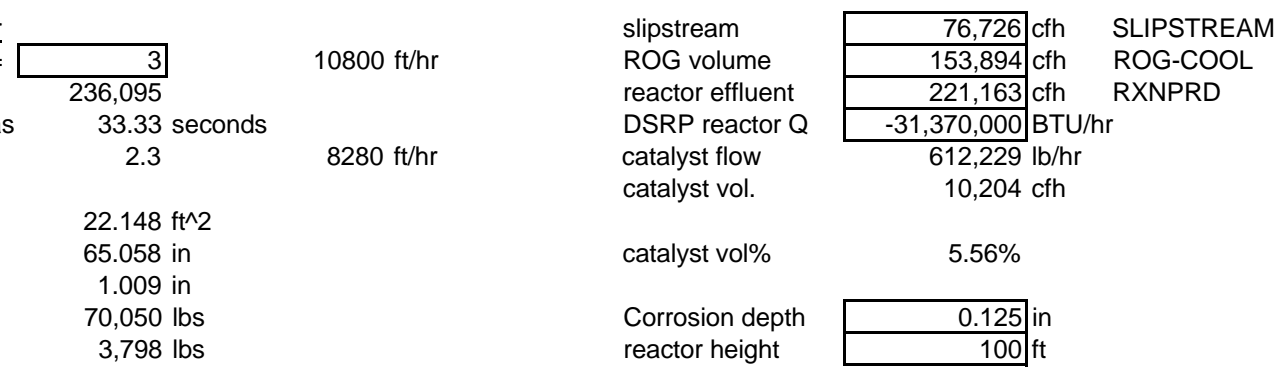

total wt.

84,925 lbs (includes additional $15 \%$ for nozzles, manholes, etc.)

DSRP Standpipe

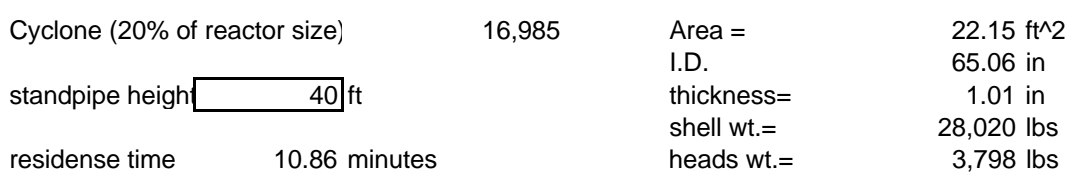

total wt.

53,575 lbs (includes additional 15\% on standpipe weight + Cyclone weight)

Heat Exchanger

Heat Exchanger Area ( $\left.\mathrm{ft}^{\wedge} 2\right)$

2174

heat exchanger pipe thickness

0.25 in

volume of steel

45

total weight

22,146 lbs

total wt.

160,646 lbs

weight for DSRP reactor system

$\underline{\operatorname{COST}}$

C.S. unit price for quantiy needed

$1.477 \$ / \mathrm{lb}$

1990 \$

$1.579 \$ / \mathrm{lb}$

1996 \$

$>100,000 \mathrm{lb}$ calc

$1.477409568 \quad 1.359$

$<100,000 \mathrm{lb}$ calc

Cost of installation

$\$ 507,200$

Total reactor cost

$\$ 1,394,800$ includes cost of installation 


\section{Appendix I \\ Sizing Reactors for the AHGP}

Copies of the reactor system sizing calculations follow. They include estimates of the reactor system costs. The equations describe in Appendix $G$ - Calculation of Reactor Size where used in the spreadsheet. 
reactors AHGP

Desulf and Regen transport reactor price calculation

AHGP

$\underline{\mathrm{N} 2 \text { lift }}$

$\overline{\mathrm{v}(\mathrm{ft} / \mathrm{sec})}=$

$\mathrm{V}(\mathrm{cfh})=$

Area $=$
I.D.

thickness=

shell wt. =

heads wt.=

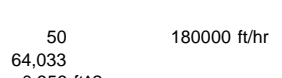

64,033

$0.356 \mathrm{ft}^{\wedge} 2$
$8.245 \mathrm{in}$

0.237

$2,085 \mathrm{lbs}$
$14 \mathrm{lbs}$

total wt.

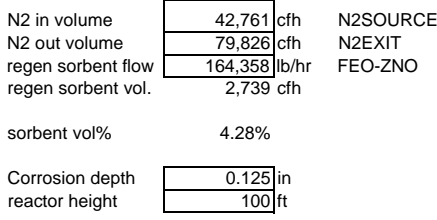

$\frac{\text { key }}{\text { caculated or constant values }}$ inputed variables

$\underline{\text { Regenerator Standpipe }}$

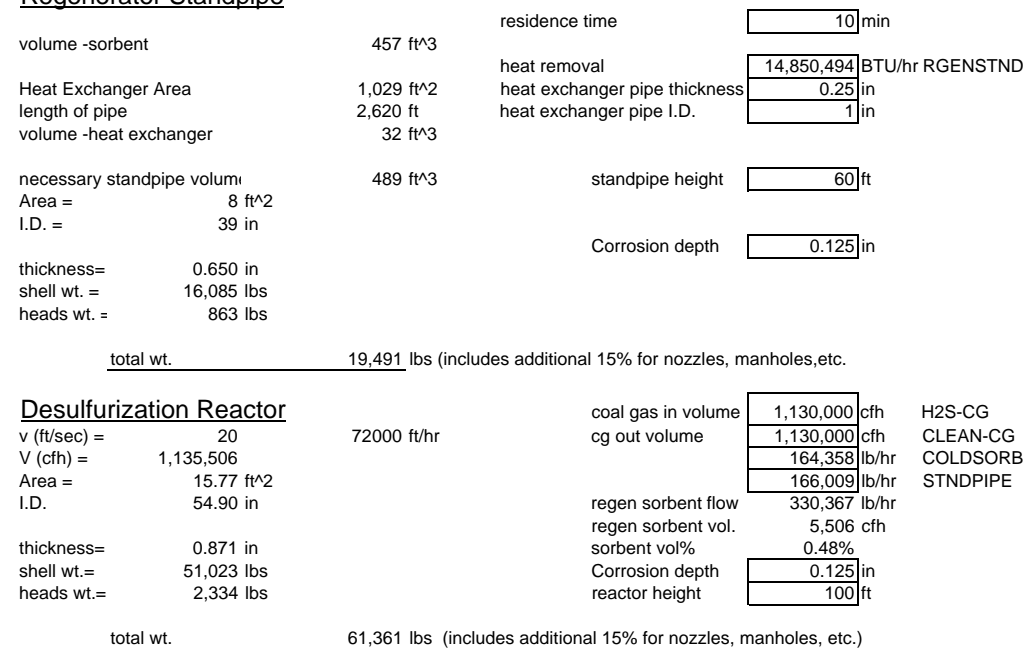

Desulfurization Standpipe

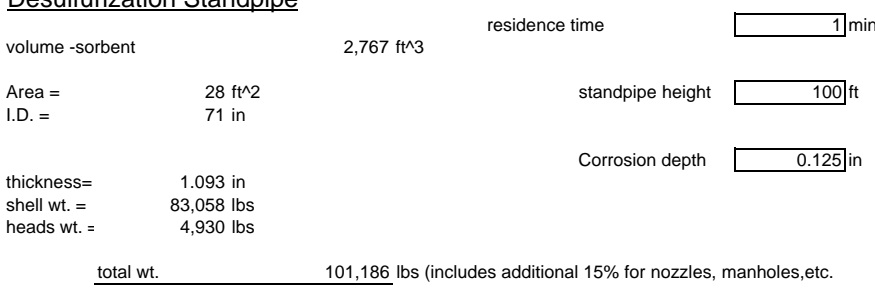

\section{Three Stage Regenerator}

\begin{tabular}{|c|c|c|c|}
\hline & \multirow{2}{*}{$\begin{array}{l}\text { number of reactors } \\
\text { standpipe height }\end{array}$} & \multirow{2}{*}{$\begin{aligned} 2 \\
45 \\
\mathrm{ft}\end{aligned}$} \\
\hline $\begin{array}{l}\text { I.D. }= \\
I D=\end{array}$ & $13.01 \mathrm{ft}$ & & \\
\hline $\begin{array}{l}1.0 .= \\
\text { thickness= }\end{array}$ & $100 \mathrm{~min}$ & & \\
\hline shell wt. = & $168,516 \mathrm{lbs}$ & Corrosion depth & 0.125 in \\
\hline heads wt. = & $48,735 \mathrm{lbs}$ & & \\
\hline & & al $20 \%$ for cyclones, & s, manholes, etc. \\
\hline
\end{tabular}

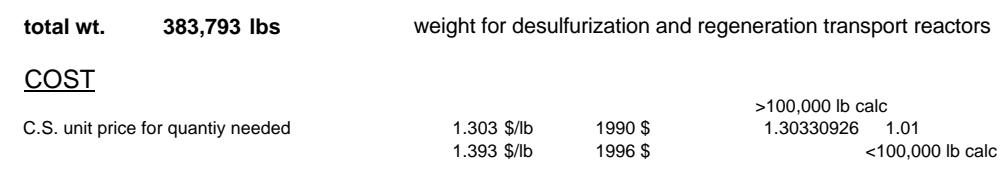

Cost of installation $\$ 1,068,941$

Total reactor cost $\$ 2,939,588$ includes cost of installation

SO2 Regenerator Sizing - Commercial Embodiment

\begin{tabular}{|c|c|c|c|c|c|}
\hline \multirow[b]{2}{*}{ Givens: } & \multirow[t]{2}{*}{$\begin{array}{l}\text { Revised } \\
\text { (SO2 Regen) } \\
\text { Case E-2 }\end{array}$} & \multicolumn{2}{|l|}{ Calculated values: } & \multicolumn{2}{|c|}{ Operating conditions/Gas Density Calc'ns: } \\
\hline & & $\begin{array}{l}\text { Hold-up volume, ft3 } \\
\text { Diameter, } \mathrm{ft}\end{array}$ & $\begin{array}{l}2660.41667 \\
18.4047564\end{array}$ & $\begin{array}{l}\text { Pressure, psig } \\
\text { Pressure, psia }\end{array}$ & $\begin{array}{r}275 \\
289.7\end{array}$ \\
\hline Sorbent circulation rate, $\mathrm{lb} / \mathrm{h}$ & 166010 & $\mathrm{X}$-section area, $\mathrm{ft} 2$ & 266.041667 & MW of gas & \\
\hline Sorbent bulk density, Ib/ft3 & 62.4 & Calculated H/D & 0.54333781 & Bed Temp., C & \\
\hline Req'd rxtr residence time, $\mathrm{hl}_{\mathrm{l}}$ & 1 & RG Vol. flow rate, act/sec & 21.8210028 & Bed Temp., $\mathrm{R}$ & 1571.6 \\
\hline Regen Gas $v_{\text {super }}, \mathrm{cm} / \mathrm{sec}$ & 2.5 & $\mathrm{RG}$ flow rate, $\mathrm{lb} / \mathrm{hr}$ & 86366.3549 & $\mathrm{R}$, gas constant, & 10.7 \\
\hline Desired H/D & 2 & $\begin{array}{l}\text { Ratio of RG flow/sorbent, lb/lb } \\
\text { Calculated Bed Depth, } \mathrm{ft}\end{array}$ & 0.52024791 & Gas density, $\mathrm{lb} / \mathrm{ft} 3$ & 1.0994 \\
\hline Adjusted values: & & & & & \\
\hline Assumed Bed Depth, ft & 10 & & & & \\
\hline $\mathrm{SO} 2$ needed ft $3 / \mathrm{hr}$ & 79812.5 & & & & \\
\hline
\end{tabular}


AHGP-b

Desulf and Regen transport reactor price calculation

\begin{tabular}{|c|c|c|c|c|c|}
\hline \multicolumn{6}{|c|}{ 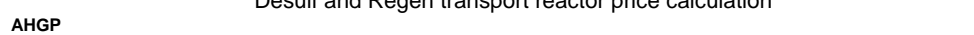 } \\
\hline N2 lift & & & N2 in volume & $91,631 \mathrm{cfh}$ & N2SOURCE \\
\hline $\mathrm{v( \textrm {ft } / \mathrm { sec } )}=$ & 50 & $180000 \mathrm{ft} / \mathrm{hr}$ & $\mathrm{N} 2$ out volume & $175,069 \mathrm{cfh}$ & N2EXIT \\
\hline$V(c f h)=$ & 141,578 & & regen sorbent flow & $493,650 \mathrm{lb} / \mathrm{hr}$ & FEO-ZNO \\
\hline Area $=$ & $0.787 \mathrm{ft}^{\wedge} 2$ & & regen sorbent vol. & $8,228 \mathrm{cfh}$ & \\
\hline I.D. & 12.260 in & & & & \\
\hline & & & sorbent vol\% & $5.81 \%$ & \\
\hline thickness= & 0.292 & & & & \\
\hline shell wt.= & 3,815 lbs & & Corrosion depth & 0.125 in & \\
\hline heads wt.= & $39 \mathrm{lbs}$ & & reactor height & $100 \mathrm{ft}$ & \\
\hline
\end{tabular}

$\frac{\text { key }}{\text { caculated or constant values }}$ inputed variables

\section{$\underline{\text { Regenerator Standpipe }}$}
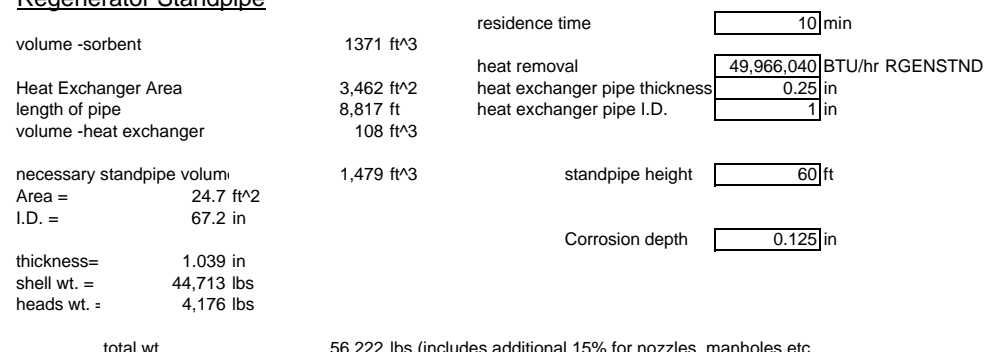

total wt.

56,222 lbs (includes additional 15\% for nozzles, manholes,etc.

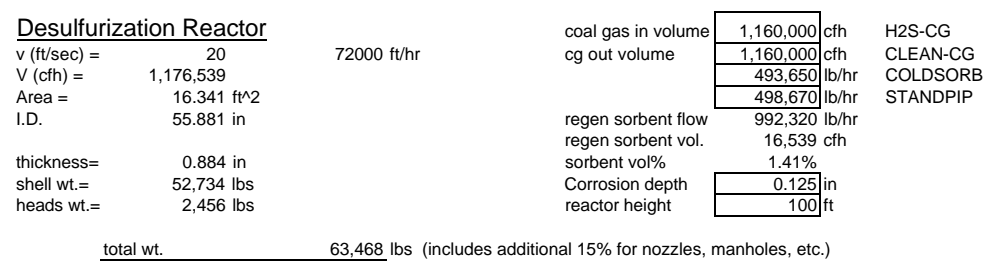

\section{Desulfurization Standpipe}

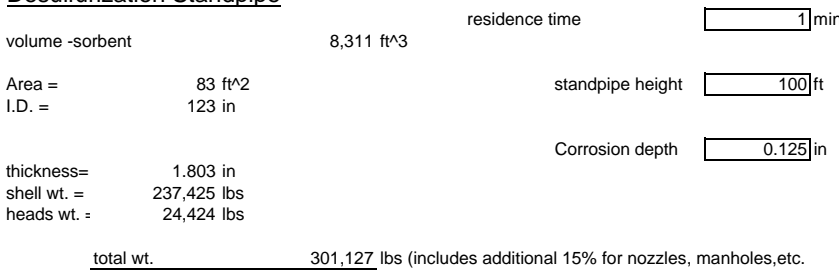

Three Stage Regenerators

\begin{tabular}{|c|c|c|c|}
\hline I.D. = & $12.99 \mathrm{ft}$ & $\begin{array}{l}\text { number of reactors } \\
\text { standpipe height }\end{array}$ & $\begin{array}{r}6 \\
45 \\
\mathrm{ft}\end{array}$ \\
\hline $\begin{array}{l}\text { l.D. }= \\
\text { thickness= }\end{array}$ & $\begin{array}{r}156 \text { in } \\
2.243 \text { in }\end{array}$ & & \\
\hline shell wt. = & $167,848 \mathrm{lbs}$ & Corrosion depth & $0.125 \mathrm{in}$ \\
\hline heads wt. = & $48,443 \mathrm{lbs}$ & & \\
\hline
\end{tabular}

total wt. $\quad 1,919,076 \mathrm{lbs} \quad$ weight for desulfurization and regeneration transport reactors

\section{$\underline{\mathrm{COST}}$}

C.S. unit price for quantiy needed

Cost of installation

Total reactor cost

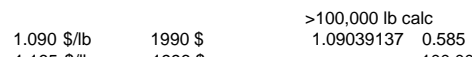

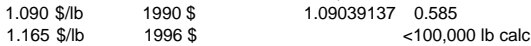

SO2 Regenerator Sizing - Commercial Embodiment

AHGP-b

Givens:

(SO2 Regen)

Sorbent circulation rate, $\mathrm{lb} / \mathrm{t}$ Sorbent bulk density, lb/tt3

Req'd rxtr residence time, $h$

Regen Gas $\mathrm{v}_{\text {super }}, \mathrm{cm} / \mathrm{sec}$

Desired $H / D$

496000

Calculated values:

Hold-up volume,

$\mathrm{X}$-section area, $\mathrm{ft} 2$

Calculated H/D 258042.961

Ratio of RG flow/sorbent, lb/b 0.52024791 Calculated Bed Depth, $\mathrm{ft}$

Operating conditions/Gas Density Calc'ns: Pressure, psig
Pressure, psia $\mathrm{MW}$ of gas Bed Temp., Bed Temp., R

$R$, gas constant,

Gas density, lb/tt3

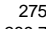

289.7
64

djusted values:

Assumed Bed Depth,

10
238461.5385 
Desulf and Regen transport reactor price calculation

\begin{tabular}{|c|c|c|c|c|c|c|}
\hline \multicolumn{7}{|c|}{ 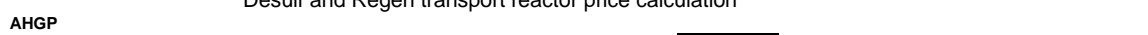 } \\
\hline N2 lift & & & $\mathrm{N} 2$ in volume & & & \\
\hline$\overline{v(f t / s e c)}=$ & 50 & $180000 \mathrm{ft} / \mathrm{hr}$ & N2 out volume & $\begin{aligned} 0,004 \\
16,326 \\
c f h\end{aligned}$ & N2EXIT & \\
\hline$V(\mathrm{cfh})=$ & 13,240 & & regen sorbent flow & $48,050 \mathrm{lb} / \mathrm{hr}$ & FEO-ZNO & \\
\hline Area $=$ & $0.074 \mathrm{ft}^{\wedge} 2$ & & regen sorbent vol. & $801 \mathrm{chh}$ & & \\
\hline I.D. & 3.749 in & & & & & key \\
\hline & & & sorbent vol\% & $6.05 \%$ & & caculated or constant values \\
\hline thickness= & 0.176 & & & & & inputed variables \\
\hline $\begin{array}{l}\text { shell wt. }= \\
\text { heads wt. }=\end{array}$ & $\begin{array}{r}704 \mathrm{lbs} \\
2 \mathrm{lbs}\end{array}$ & & $\begin{array}{l}\text { Corrosion depth } \\
\text { reactor height }\end{array}$ & $\frac{0.125}{100} \mathrm{in}$ & & \\
\hline
\end{tabular}

total wt. $\quad 812$ lbs (includes additional $15 \%$ for nozzles, manholes, etc.)

\section{$\underline{\text { Regenerator Standpipe }}$}

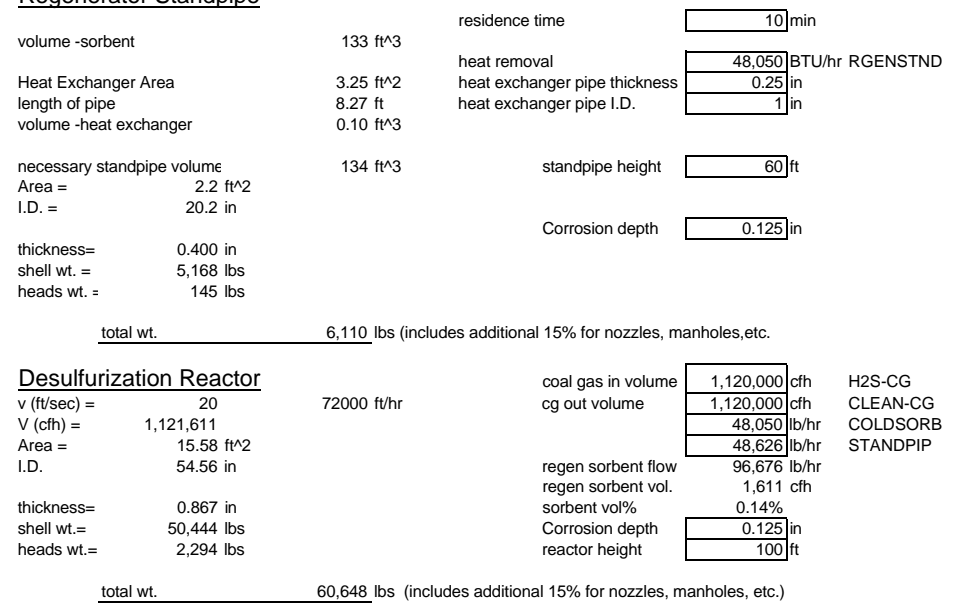

Desulfurization Standpipe

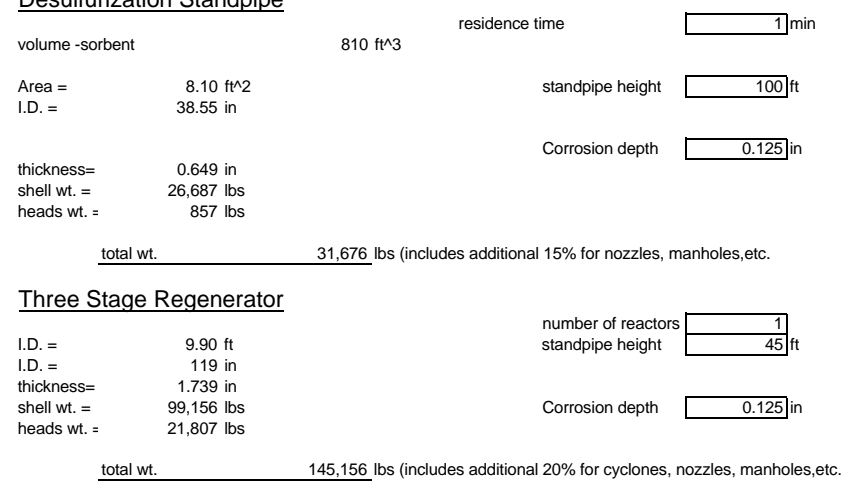

\begin{tabular}{|c|c|c|c|c|c|c|}
\hline \multirow{2}{*}{$\begin{array}{l}\text { total wt. } \\
\text { COST }\end{array}$} & & \multicolumn{5}{|c|}{ weight for desulfurization and regeneration transport reactors } \\
\hline & \\
\hline \multicolumn{2}{|c|}{ C.S. unit price for quantiy needed } & \multicolumn{5}{|c|}{$\begin{array}{l}>100,000 \mathrm{lb} \text { calc } \\
\begin{aligned} 1.44706713 \quad & 1.298 \\
& <100,000 \mathrm{lb} \text { calc }\end{aligned}\end{array}$} \\
\hline Cost of installation & \multicolumn{6}{|l|}{$\$ 568,244$} \\
\hline Total reactor cost & \multicolumn{6}{|c|}{$\$ 1,562,672$ includes cost of installation } \\
\hline \multicolumn{7}{|c|}{ SO2 Regenerator Sizing - Commercial Embodiment } \\
\hline & \multirow{3}{*}{$\begin{array}{l}\text { Regen) } \\
\text { Case E-2 }\end{array}$} & \multirow{2}{*}{\multicolumn{2}{|c|}{$\begin{array}{l}\text { Calculated values: } \\
\text { Hold-up volume, ft3 }\end{array}$}} & & \multicolumn{2}{|c|}{ Operating conditions/Gas Density Calc'ns: } \\
\hline \multirow[t]{2}{*}{ Givens: } & & & & 769.23 & Pressure, psig & 275 \\
\hline & & Diam & & 9.90 & Pressure, psia & 289.7 \\
\hline Sorbent circulation rate, lb/h & 48000 & $X-\sec$ & $n$ area, ft2 & 76.92 & MW of gas & 64 \\
\hline Sorbent bulk density, lb/tt3 & 62.4 & Calcu & ed H/D & 1.01 & Bed Temp., C & 600 \\
\hline Req'd rxtr residence time, hr & 1 & RG V & flow rate, acf/sec & 6.31 & Bed Temp., R & 1571.67 \\
\hline Regen Gas v vuper, $\mathrm{cm} / \mathrm{sec}$ & 2.5 & $\mathrm{RG}$ flc & rate, $\mathrm{lb} / \mathrm{hr}$ & 24971.90 & $\mathrm{R}$, gas constant, & 10.73 \\
\hline Desired H/D & 2 & $\begin{array}{l}\text { Ratio } \\
\text { Calcu }\end{array}$ & $\begin{array}{l}\text { RG flow/sorbent, Ib/lb } \\
\text { ed Bed Depth, ft }\end{array}$ & 0.52 & Gas density, lb/tt3 & 1.10 \\
\hline Adjusted values: & & & & & & \\
\hline Assumed Bed Depth, ft & 10 & & & & & \\
\hline
\end{tabular}


AHGP-100

Desulf and Regen transport reactor price calculation ( 0.4211 the size of the AHGP case)

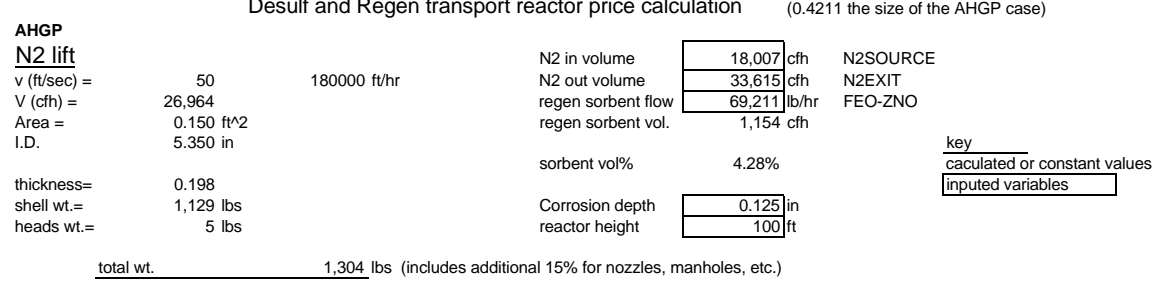

\section{Regenerator Standpipe}

\begin{tabular}{|c|c|c|c|c|c|}
\hline \multicolumn{4}{|r|}{ residence time } & \multirow{2}{*}{\multicolumn{2}{|c|}{\begin{tabular}{|r}
$10 \mathrm{~min}$ \\
\end{tabular}}} \\
\hline \multirow{2}{*}{\multicolumn{2}{|c|}{ volume -sorbent }} & $192 \mathrm{ft} \wedge 3$ & residence time & & \\
\hline & & 80 & heat removal & $6,253,543$ BTU/ & ir RGENSTND \\
\hline \multicolumn{2}{|c|}{ Heat Exchanger Area } & $433 \mathrm{ft}^{\wedge} 2$ & heat exchanger pipe thickness & 0.25 in & \\
\hline \multicolumn{2}{|c|}{$\begin{array}{l}\text { length of pipe } \\
\text { volume -heat exchanger }\end{array}$} & $\begin{array}{l}1,103 \mathrm{ft} \\
14 \mathrm{ft}^{\wedge} 3\end{array}$ & heat exchanger pipe I.D. & 1 in & \\
\hline \multicolumn{2}{|c|}{ necessary standpipe volum $\epsilon$} & $206 \mathrm{ft}^{\wedge} 3$ & standpipe height & $60 \mathrm{ft}$ & \\
\hline \multirow{2}{*}{$\begin{array}{l}\text { Area }= \\
\text { I.D. }=\end{array}$} & $3.43 \mathrm{ft}^{\wedge} 2$ & & & & \\
\hline & 25.08 in & & Corrosion depth & 0.125 in & \\
\hline \multirow{3}{*}{$\begin{array}{l}\text { thickness= } \\
\text { shell wt. = } \\
\text { heads wt. = }\end{array}$} & 0.466 in & & & & \\
\hline & $7,478 \mathrm{lbs}$ & & & & \\
\hline & $260 \mathrm{lbs}$ & & & & \\
\hline \multicolumn{2}{|c|}{ total wt. } & \multicolumn{4}{|c|}{8,899 Ibs (includes additional $15 \%$ for nozzles, manholes, etc. } \\
\hline \multicolumn{2}{|c|}{ Desulfurization Reactor } & & coal gas in volume & $475,843 \mathrm{cfh}$ & H2S-CG \\
\hline$v(\mathrm{ft} / \mathrm{sec})=$ & 20 & $72000 \mathrm{ft} / \mathrm{hr}$ & cg out volume & $475,843 \mathrm{cfh}$ & CLEAN-CG \\
\hline$V(\mathrm{cfh})=$ & 478,162 & & & $69,211 \mathrm{lb} / \mathrm{hr}$ & COLDSORB \\
\hline Area $=$ & $6.64 \mathrm{ft}^{\wedge} 2$ & & & $69,906 \mathrm{lb} / \mathrm{hr}$ & STNDPIPE \\
\hline I.D. & 35.62 in & & $\begin{array}{l}\text { regen sorbent flow } \\
\text { regen sorbent vol. }\end{array}$ & $\begin{array}{c}139,118 \mathrm{lb} / \mathrm{hr} \\
2,319 \mathrm{cfh}\end{array}$ & \\
\hline thickness $=$ & 0.609 in & & sorbent vol\% & $0.48 \%$ & \\
\hline shell wt.= & $23,154 \mathrm{lbs}$ & & Corrosion depth & 0.125 in & \\
\hline heads wt. $=$ & $687 \mathrm{lbs}$ & & reactor height & $100 \mathrm{ft}$ & \\
\hline
\end{tabular}

total wt. $\quad 27,418$ lbs (includes additional $15 \%$ for nozzles, manholes, etc.)

Desulfurization Standpipe

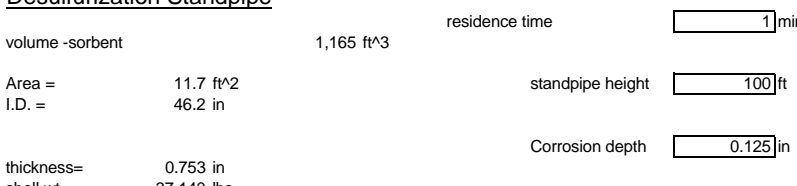

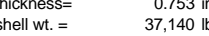

heads wt. $=\quad 1,430 \mathrm{lbs}$

total wt. $\quad 44,356$ lbs (includes additional $15 \%$ for nozzles, manholes,etc.

Three Stage Regenerators

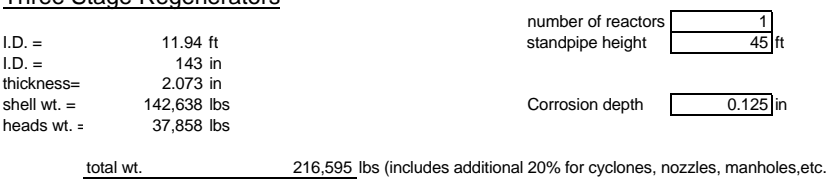

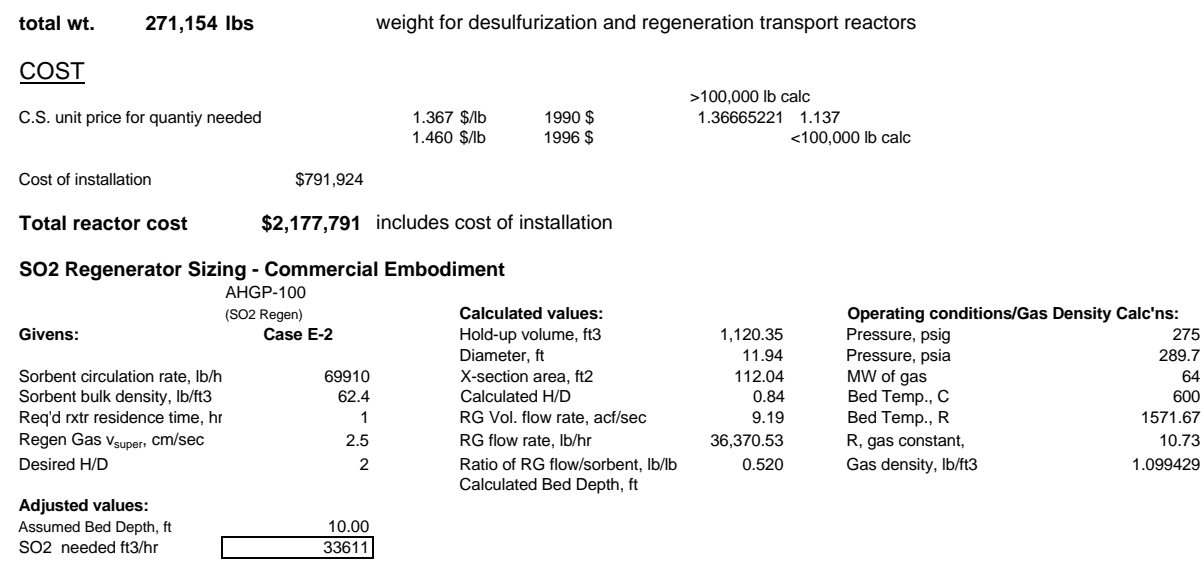


AHGP-500

Desulf and Regen transport reactor price calculation (2.1055 the size of the AHGP case)

\begin{tabular}{|c|c|c|c|c|c|c|}
\hline \multirow{3}{*}{$\begin{array}{l}\text { AHGP } \\
\text { N2 lift }\end{array}$} & \multirow{2}{*}{\multicolumn{4}{|c|}{ Desulf and Regen transport reactor price calculation }} & \multicolumn{2}{|c|}{ (2.1055 the size of the AHGP case) } \\
\hline & & & & & & \\
\hline & & & $\mathrm{N} 2$ in volume & $90,033 \mathrm{cfh}$ & N2SOURCE & \\
\hline$\overline{v(\mathrm{ft} / \mathrm{sec})}=$ & 50 & $180000 \mathrm{ft} / \mathrm{hr}$ & N2 out volume & $168,074 \mathrm{cfh}$ & N2EXIT & \\
\hline$V(\mathrm{cfh})=$ & 134,821 & & regen sorbent flow & $346,056 \mathrm{lb} / \mathrm{hr}$ & FEO-ZNO & \\
\hline Area $=$ & $0.75 \mathrm{ft}^{\wedge} 2$ & & regen sorbent vol. & $5,768 \mathrm{cfh}$ & & \\
\hline I.D. & 11.96 in & & & & & key \\
\hline & & & sorbent vol\% & $4.28 \%$ & & caculated or constant values \\
\hline thickness= & 0.287592409 & & & & & inputed variables \\
\hline $\begin{array}{l}\text { shell wt.= } \\
\text { heads wt.= }\end{array}$ & $\begin{array}{r}3,671 \mathrm{lbs} \\
37 \mathrm{lbs}\end{array}$ & & $\begin{array}{l}\text { Corrosion depth } \\
\text { reactor height }\end{array}$ & $\begin{array}{rl}0.125 & \text { in } \\
100 & \mathrm{ft} \\
\end{array}$ & & \\
\hline & btal wt. & & $15 \%$ for nozzles, & les, etc.) & & \\
\hline
\end{tabular}

4,264 Ibs (includes additional 15\% for nozzles, manholes, etc.)

Regenerator Standpipe

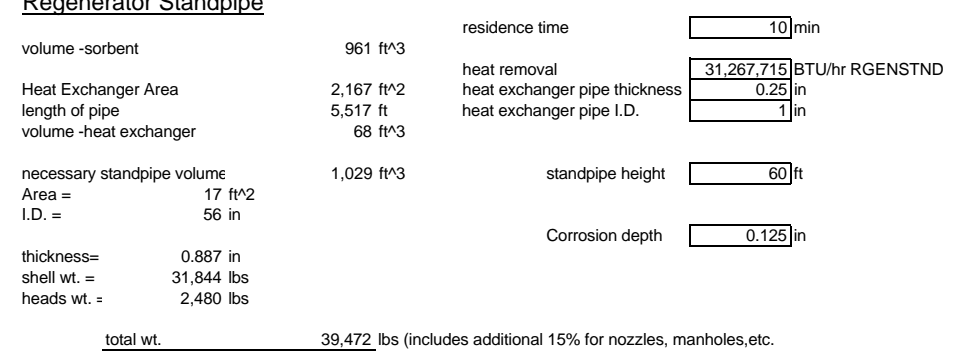

\begin{tabular}{|c|c|c|c|c|c|}
\hline \multicolumn{2}{|c|}{ Desulfurization Reactor } & \multirow[b]{2}{*}{$72000 \mathrm{ft} / \mathrm{hr}$} & \multirow{3}{*}{$\begin{array}{l}\text { coal gas in volume } \\
\text { cg out volume }\end{array}$} & $2,379,215 \mathrm{cfh}$ & \multirow{4}{*}{$\begin{array}{l}\text { H2S-CG } \\
\text { CLEAN-CG } \\
\text { COLDSORE } \\
\text { STNDPIPE }\end{array}$} \\
\hline$v(\mathrm{t} / \mathrm{sec})=$ & 20 & & & $2,379,215 \mathrm{chh}$ & \\
\hline$V(\mathrm{cfh})=$ & $2,390,808$ & & & $346,056 \mathrm{lb} / \mathrm{hr}$ & \\
\hline I.D. & $79.66 \mathrm{in}$ & & regen sorbent flow & $\begin{array}{l}349,532 \mathrm{l} \mathrm{b} / \mathrm{hr} \\
695,588 \mathrm{lb} / \mathrm{hr}\end{array}$ & \\
\hline $\begin{array}{l}\text { thickness= } \\
\text { shell wt.= } \\
\text { heads wt.= }\end{array}$ & $\begin{array}{r}1.208 \text { in } \\
102,638 \mathrm{lbs} \\
6,813 \mathrm{lbs}\end{array}$ & & $\begin{array}{l}\text { regen sorbent vol. } \\
\text { sorbent vol\% } \\
\text { Corrosion depth } \\
\text { reactor height }\end{array}$ & $\begin{array}{l}11,593 \mathrm{cfh} \\
0.48 \% \\
0.125 \\
100 \mathrm{ft}\end{array}$ & \\
\hline
\end{tabular}

Desulfurization Standpipe

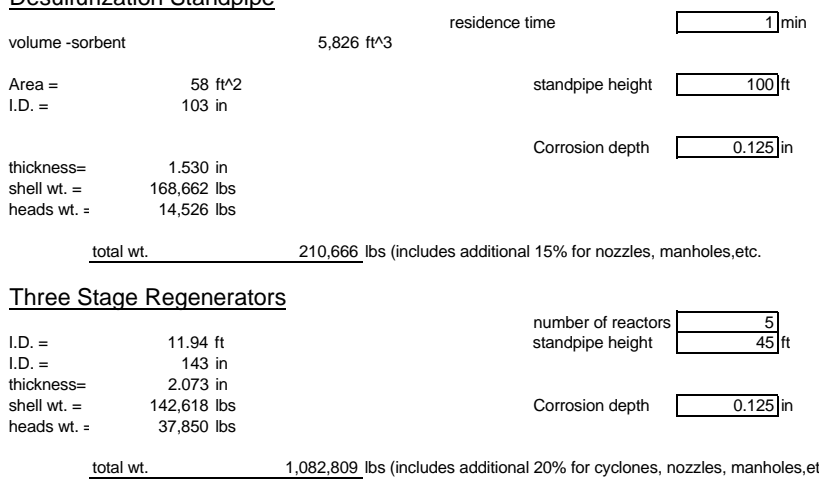

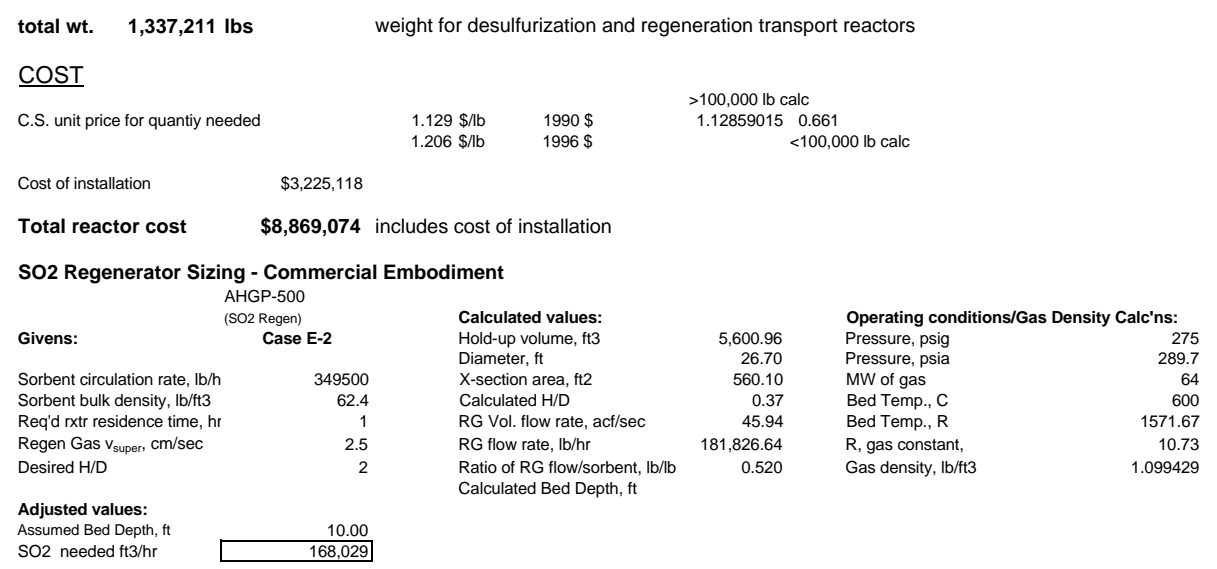




\section{Appendix J \\ Power Generation Achievable from Clean Coal Gas}

Two sources where used in determining the power generated by the clean coal gas. The Sierra power generating facility was used as the basis for determining the power generating capacity coal gas.

\begin{tabular}{|c|c|c|}
\hline $\mathrm{H}_{2}$ (lbmole/hr) & $\begin{array}{l}\text { rra Clean Coal Gas Feed } \\
\text { CO (lbmole/hr) }\end{array}$ & Power Generation (MW \\
\hline 5760 & 7570 & 260 \\
\hline
\end{tabular}

The individual contribution of the $\mathrm{H}_{2}$ and $\mathrm{CO}$ where determined assuming there relative contribution was consistent with their standard heats of combustion.

Standard heat of combustion (Felled \& Rousseau):

$\Delta \mathrm{H}_{\text {comb }}^{\mathrm{o}}\left(\mathrm{H}_{2}\right)=-3.605 \mathrm{E}-2 \mathrm{MW} \mathrm{hr} / \mathrm{lbmole} \quad \Delta \mathrm{H}_{\text {comb }}^{\mathrm{o}}(\mathrm{CO})=-3.569 \mathrm{E}-2 \mathrm{MW} \mathrm{hr} / \mathrm{lbmole}$

Power generation can be expressed:

$$
\mathrm{E}\left[5760 \Delta \mathrm{H}_{\mathrm{C}}\left(\mathrm{H}_{2}\right)+7570 \Delta \mathrm{H}_{\mathrm{C}}(\mathrm{CO})\right]=260 \mathrm{MW}
$$

where:

$$
\mathrm{E}=\text { Efficiency of power generation }
$$

assuming:

$$
\Delta \mathrm{H}_{\mathrm{C}}(\mathrm{CO})=0.99 \Delta \mathrm{H}_{\mathrm{C}}\left(\mathrm{H}_{2}\right)
$$

and substituting gives:

$$
13,254 \mathrm{E} \Delta \mathrm{H}_{\mathrm{C}}\left(\mathrm{H}_{2}\right)=260 \mathrm{MW}
$$

therefore

$$
\mathrm{E} \Delta \mathrm{H}_{\mathrm{C}}\left(\mathrm{H}_{2}\right)=0.0196 \mathrm{MW} \mathrm{hr} / \mathrm{lbmole}
$$

$$
\mathrm{E} \Delta \mathrm{H}_{\mathrm{C}}(\mathrm{CO})=0.0194 \mathrm{MW} \mathrm{hr} / \mathrm{lbmole}
$$

The values calculated above can be used to write a power generation expression.

$$
\text { Power Generation }\{\mathrm{MW}\}=0.0196\left(\mathrm{H}_{2}\{\mathrm{lbmoles} / \mathrm{hr}\}\right)+0.0194(\mathrm{CO}\{\mathrm{lbmoles} / \mathrm{hr}\})
$$

The plants power generation is determined by inserting the clean coal gas flows for $\mathrm{H}_{2}$ and $\mathrm{CO}$ into the above equation. HGD coal gas consumption is assessed as a debit equivalent to the cost of the lost power generation. The power generation lost is determined by inserting the difference in the dirty coal gas and clean coal gas molar flow rates into the above equation. The cost of the electricity is taken as $\$ 0.04$ per $\mathrm{kWh}$. The plant has been assumed to be in operation $90 \%$ of the year. 
Summary of Power Generation Calculations

\begin{tabular}{lrrrrrr}
\multicolumn{1}{c}{ simulation } & $\mathbf{H}_{2}$ clean & $\mathbf{H}_{2}$ in & Co clean & CO in & MW made & MW lost \\
DSRP & $11,444.58$ & $11,765.37$ & $212,200.52$ & $218,162.00$ & 258.25 & 7.248 \\
DSRP-b & $11,450.19$ & $12,468.32$ & $212,276.67$ & $231,196.50$ & 258.35 & 23.003 \\
DSRP-C & $11,443.82$ & $11,535.37$ & $212,195.77$ & $213,897.17$ & 258.24 & 2.069 \\
DSRP-100 & $4,819.31$ & $4,954.40$ & $89,357.59$ & $91,868.05$ & 108.75 & 3.052 \\
DSRP-500 & $24,110.94$ & $24,772.09$ & $447,055.34$ & $459,341.97$ & 544.06 & 14.938 \\
AHGP & $11,355.75$ & $11,510.68$ & $213,439.25$ & $213,439.25$ & 258.24 & 1.506 \\
AHGP-b & $11,175.21$ & $11,646.28$ & $215,953.67$ & $215,953.67$ & 258.23 & 4.580 \\
AHGP-c & $11,419.66$ & $11,464.48$ & $212,582.61$ & $212,582.61$ & 258.27 & 0.436 \\
AHGP-100 & $4,781.91$ & $4,847.15$ & $89,879.27$ & $89,879.27$ & 108.74 & 0.634 \\
AHGP-500 & $23,909.53$ & $24,235.73$ & $449,396.34$ & $449,396.34$ & 543.72 & 3.172
\end{tabular}




\section{Appendix K \\ Calculation of Reactor Pressure Drops}

Pressure drops for transport reactors have been calculated assuming the pressure drops are related to the energy required to lift the sorbent / catalyst to the top of the reactor.

Energy balance for lifting solid to top of reactor:

$$
\begin{aligned}
& \Delta \mathrm{E}_{\mathrm{PART}}=\Delta \mathrm{E}_{\mathrm{GAS}} \\
& \mathrm{m}_{\mathrm{PART}}\left(\mathrm{g} / \mathrm{g}_{\mathrm{C}}\right) \mathrm{h}=\Delta \mathrm{P} \mathrm{m}_{\mathrm{GAS}} / \rho_{\mathrm{GAS}} \\
& \Delta \mathrm{P}=\mathrm{m}_{\mathrm{PART}}\left(\mathrm{g} / \mathrm{g}_{\mathrm{C}}\right) \mathrm{h} \rho_{\mathrm{GAS}} / \mathrm{m}_{\mathrm{GAS}} \\
& \Delta \mathrm{P}_{\text {REACTOR }}=1.5 \text { (Energy to lift particle) }
\end{aligned}
$$

DSRP Regeneration Reactor

$$
\Delta \mathrm{P}=1.5 \mathrm{~m}_{\mathrm{PART}}\left(\mathrm{g} / \mathrm{g}_{\mathrm{C}}\right) \mathrm{h} \rho_{\mathrm{GAS}} / \mathrm{m}_{\mathrm{GAS}}
$$

$\mathrm{m}_{\text {PART }}=$ sorbent mass flow, ZNS2RGEN \& ZNO average

$\left(\mathrm{g} / \mathrm{g}_{\mathrm{C}}\right)=1 \mathrm{lb}_{\mathrm{f}} / \mathrm{lb}_{\mathrm{m}}$

$\mathrm{h}=$ reactor height, defined in Appendix $\mathrm{H}$

$\rho_{\mathrm{GAS}}=$ gas density, HP-O2-N2 \& ROG average

$\mathrm{m}_{\mathrm{GAS}}=$ gas mass flow, HP-O2-N2 \& ROG average

DSRP Regeneration Reactor (DSRP)

$$
\begin{aligned}
& \Delta \mathrm{P}=1.5\left(250,000 \mathrm{lb} \mathrm{m}_{\mathrm{m}} / \mathrm{hr}\right)\left(1 \mathrm{lb}_{\mathrm{f}} / \mathrm{lb}_{\mathrm{m}}\right)(100 \mathrm{ft})\left(0.5 \mathrm{lb}_{\mathrm{m}} / \mathrm{ft}^{3}\right) /(40,000 \mathrm{lb} / \mathrm{hr})\left(1 \mathrm{ft}^{3} / 144 \mathrm{in}^{2}\right) \\
& \Delta \mathrm{P}=3.32 \mathrm{psi}
\end{aligned}
$$

DSRP Regeneration Reactor (DSRP-b)

$$
\begin{aligned}
& \Delta \mathrm{P}=1.5\left(1,200,000 \mathrm{lb} \mathrm{m}_{\mathrm{m}} / \mathrm{hr}\right)\left(1 \mathrm{lb}_{\mathrm{f}} / \mathrm{lb}_{\mathrm{m}}\right)(100 \mathrm{ft})\left(0.5 \mathrm{lb}_{\mathrm{m}} / \mathrm{ft}^{3}\right) /(130,000 \mathrm{lb} \mathrm{m} / \mathrm{hr})\left(1 \mathrm{ft}^{3} / 144 \mathrm{in}^{2}\right) \\
& \Delta \mathrm{P}=4.8 \mathrm{psi}
\end{aligned}
$$

DSRP Regeneration Reactor (DSRP-c)

$$
\begin{gathered}
\Delta \mathrm{P}=1.5\left(71,000 \mathrm{lb}_{\mathrm{m}} / \mathrm{hr}\right)\left(1 \mathrm{lb} / \mathrm{l} / \mathrm{b}_{\mathrm{m}}\right)(100 \mathrm{ft})\left(0.5 \mathrm{lb}_{\mathrm{m}} / \mathrm{ft}^{3}\right) /\left(12,000 \mathrm{lb}_{\mathrm{m}} / \mathrm{hr}\right)\left(1 \mathrm{ft}^{3} / 144 \mathrm{in}^{2}\right) \\
\Delta \mathrm{P}=3.2 \mathrm{psi}
\end{gathered}
$$

DSRP Regeneration Reactor (DSRP-100) (DSRP-500) 
DSRP Reactor

$$
\Delta \mathrm{P}=1.5 \mathrm{~m}_{\mathrm{PART}}\left(\mathrm{g} / \mathrm{g}_{\mathrm{C}}\right) \mathrm{h} \rho_{\mathrm{GAS}} / \mathrm{m}_{\mathrm{GAS}}
$$

$\mathrm{m}_{\mathrm{PART}}=$ catalyst mass flow, Appendix $\mathrm{H}$

$\left(\mathrm{g} / \mathrm{g}_{\mathrm{C}}\right)=1 \mathrm{lb}_{\mathrm{f}} / \mathrm{lb}_{\mathrm{m}}$

$\mathrm{h}=$ reactor height, defined in Appendix $\mathrm{H}$

$\rho_{\mathrm{GAS}}=$ gas density, ROG-COOL \& RXNPRD average

$\mathrm{m}_{\mathrm{GAS}}=$ gas mass flow, $\mathrm{RXNPRD}$

DSRP Reactor (DSRP)

$$
\begin{aligned}
& \Delta \mathrm{P}=1.5\left(300,000 \mathrm{lb} \mathrm{m}_{\mathrm{m}} / \mathrm{hr}\right)\left(1 \mathrm{lb}_{\mathrm{f}} / \mathrm{lb}_{\mathrm{m}}\right)(100 \mathrm{ft})\left(0.53 \mathrm{lb}_{\mathrm{m}} / \mathrm{ft}^{3}\right) /(55,000 \mathrm{lb} / / \mathrm{hr})\left(1 \mathrm{ft}^{3} / 144 \mathrm{in}^{2}\right) \\
& \Delta \mathrm{P}=3.0 \mathrm{psi}
\end{aligned}
$$

\section{DSRP Reactor (DSRP-b)}

$$
\begin{aligned}
& \Delta \mathrm{P}=1.5\left(1,000,000 \mathrm{lb} \mathrm{m}_{\mathrm{m}} / \mathrm{hr}\right)\left(1 \mathrm{lb} / \mathrm{f} / \mathrm{b}_{\mathrm{m}}\right)(100 \mathrm{ft})\left(0.53 \mathrm{lb}_{\mathrm{m}} / \mathrm{ft}^{3}\right) /\left(185,000 \mathrm{lb} \mathrm{m}_{\mathrm{m}} / \mathrm{hr}\right)\left(1 \mathrm{ft}^{3} / 144 \mathrm{in}^{2}\right) \\
& \Delta \mathrm{P}=3.0 \mathrm{psi}
\end{aligned}
$$

\section{DSRP Reactor (DSRP-c)}

$$
\begin{gathered}
\Delta \mathrm{P}=1.5(79,000 \mathrm{lb} / \mathrm{hr})\left(1 \mathrm{lb}_{\mathrm{f}} / \mathrm{lb}_{\mathrm{m}}\right)(100 \mathrm{ft})\left(0.55 \mathrm{lb}_{\mathrm{m}} / \mathrm{ft}^{3}\right) /\left(15,000 \mathrm{lb} \mathrm{m}_{\mathrm{m}} / \mathrm{hr}^{3}\right)\left(1 \mathrm{ft}^{3} / 144 \mathrm{in}^{2}\right) \\
\Delta \mathrm{P}=3.0 \mathrm{psi}
\end{gathered}
$$

DSRP Reactor (DSRP-100) (DSRP-500)

same as base case $\quad \Delta \mathrm{P}=3.0 \mathrm{psi}$

DSRP Desulfurization Reactor

$$
\begin{aligned}
& \qquad \mathrm{P}=1.5 \mathrm{~m}_{\mathrm{PART}}\left(\mathrm{g} / \mathrm{g}_{\mathrm{C}}\right) \mathrm{h} \rho_{\mathrm{GAS}} / \mathrm{m}_{\mathrm{GAS}} \\
& \mathrm{m}_{\mathrm{PART}}=\text { sorbent mass flow, } \mathrm{ZNS} \\
& \left(\mathrm{g} / \mathrm{g}_{\mathrm{C}}\right)=1 \mathrm{lb}_{\mathrm{f}} / \mathrm{lb}_{\mathrm{m}} \\
& \mathrm{h}=\text { reactor height, defined in Appendix } \mathrm{H} \\
& \rho_{\mathrm{GAS}}=\text { gas density, RAW-CG \& CG-CALC average } \\
& \mathrm{m}_{\mathrm{GAS}}=\text { gas mass flow, CG-CALC }
\end{aligned}
$$

DSRP Desulfurization Reactor (DSRP) 


$$
\begin{aligned}
& \Delta \mathrm{P}=1.5\left(670,000 \mathrm{lb}_{\mathrm{m}} / \mathrm{hr}\right)\left(1 \mathrm{lb}_{\mathrm{f}} / \mathrm{lb}_{\mathrm{m}}\right)(100 \mathrm{ft})\left(0.4 \mathrm{lb}_{\mathrm{m}} / \mathrm{ft}^{3}\right) /(510,000 \mathrm{lb} / \mathrm{hr})\left(1 \mathrm{ft}^{3} / 144 \mathrm{in}^{2}\right) \\
& \Delta \mathrm{P}=0.6 \mathrm{psi}
\end{aligned}
$$

DSRP Desulfurization Reactor (DSRP-b)

$$
\begin{aligned}
& \Delta \mathrm{P}=1.5(2,700,000 \mathrm{lb} / \mathrm{hr})\left(1 \mathrm{lb}_{\mathrm{f}} / \mathrm{lb}_{\mathrm{m}}\right)(100 \mathrm{ft})\left(0.4 \mathrm{lb}_{\mathrm{m}} / \mathrm{ft}^{3}\right) /\left(660,000 \mathrm{lb} \mathrm{m}_{\mathrm{m}} / \mathrm{hr}\right)\left(1 \mathrm{ft}^{3} / 144 \mathrm{in}^{2}\right) \\
& \Delta \mathrm{P}=1.6 \mathrm{psi}
\end{aligned}
$$

DSRP Desulfurization Reactor (DSRP-c)

$$
\begin{aligned}
& \Delta \mathrm{P}=1.5(72,000 \mathrm{lb} / \mathrm{hr})\left(1 \mathrm{lb}_{\mathrm{f}} / \mathrm{lb}_{\mathrm{m}}\right)(100 \mathrm{ft})\left(0.4 \mathrm{lb}_{\mathrm{m}} / \mathrm{ft}^{3}\right) /\left(460,000 \mathrm{lb} \mathrm{m}_{\mathrm{m}} / \mathrm{hr}\right)\left(1 \mathrm{ft}^{3} / 144 \mathrm{in}^{2}\right) \\
& \Delta \mathrm{P}=0.06 \mathrm{psi}
\end{aligned}
$$

DSRP Desulfurization Reactor (DSRP-100) (DSRP-500)

same as base case $\quad \Delta \mathrm{P}=0.6 \mathrm{psi}$

$\underline{\text { AHGP Desulfurization Reactor }}$

$$
\Delta \mathrm{P}=1.5 \mathrm{~m}_{\mathrm{PART}}\left(\mathrm{g} / \mathrm{g}_{\mathrm{C}}\right) \mathrm{h} \rho_{\mathrm{GAS}} / \mathrm{m}_{\mathrm{GAS}}
$$

$\mathrm{m}_{\text {PART }}=$ sorbent mass flow, STNDPIPE + COLDSORB

$\left(\mathrm{g} / \mathrm{g}_{\mathrm{C}}\right)=1 \mathrm{lb}_{\mathrm{f}} / \mathrm{lb}_{\mathrm{m}}$

$\mathrm{h}=$ reactor height, defined in Appendix I

$\rho_{\mathrm{GAS}}=$ gas density, H2S-CG \& CLEAN-CG average

$\mathrm{m}_{\mathrm{GAS}}=$ gas mass flow, CLEAN-CG

AHGP Desulfurization Reactor (AHGP-100 and AHGP-500 results will be consistent)

$$
\begin{aligned}
& \Delta \mathrm{P}=1.5(330,000 \mathrm{lb} / \mathrm{hr})\left(1 \mathrm{lb}_{\mathrm{f}} / \mathrm{lb}_{\mathrm{m}}\right)(100 \mathrm{ft})\left(0.4 \mathrm{lb}_{\mathrm{m}} / \mathrm{ft}^{3}\right) /(450,000 \mathrm{lb} / \mathrm{hr})\left(1 \mathrm{ft}^{3} / 144 \mathrm{in}^{2}\right) \\
& \Delta \mathrm{P}=0.3 \mathrm{psi}
\end{aligned}
$$

AHGP-b Desulfurization Reactor

$\Delta \mathrm{P}=1.5\left(990,000 \mathrm{lb} \mathrm{m}_{\mathrm{m}} / \mathrm{hr}\right)\left(1 \mathrm{lb}_{\mathrm{f}} / \mathrm{lb}_{\mathrm{m}}\right)(100 \mathrm{ft})\left(0.4 \mathrm{lb}_{\mathrm{m}} / \mathrm{ft}^{3}\right) /(460,000 \mathrm{lb} / \mathrm{hr})\left(1 \mathrm{ft}^{3} / 144 \mathrm{in}^{2}\right)$

$$
\Delta \mathrm{P}=0.9 \mathrm{psi}
$$

AHGP-c Desulfurization Reactor

$$
\begin{aligned}
& \Delta \mathrm{P}=1.5\left(97,000 \mathrm{lb} \mathrm{m}_{\mathrm{m}} / \mathrm{hr}\right)\left(1 \mathrm{lb}_{\mathrm{f}} / \mathrm{lb}_{\mathrm{m}}\right)(100 \mathrm{ft})\left(0.4 \mathrm{lb}_{\mathrm{m}} / \mathrm{ft}^{3}\right) /\left(440,000 \mathrm{lb} \mathrm{b}_{\mathrm{m}} / \mathrm{hr}\right)\left(1 \mathrm{ft}^{3} / 144 \mathrm{in}^{2}\right) \\
& \Delta \mathrm{P}=0.09 \mathrm{psi}
\end{aligned}
$$


The pressure drop through the bubble bed regenerator is calculated as the sum of the static head in each stage times 1.3.

\section{AHGP 3-Stage Regenerator Reactor}

$$
\Delta \mathrm{P}=1.3 \mathrm{~g} / \mathrm{g}_{\mathrm{C}}\left(\rho \mathrm{h}_{\text {top-stage }}+\rho \mathrm{h}_{\text {stage } 2}+\rho \mathrm{h}_{\text {bottom-stage }}\right)(1 / 144)
$$

$\mathrm{m}_{\mathrm{PART}}=$ sorbent mass flow, FES-ZNS

$\left(\mathrm{g} / \mathrm{g}_{\mathrm{C}}\right)=1 \mathrm{lb}_{\mathrm{f}} / \mathrm{lb}_{\mathrm{m}}$

$\mathrm{h}=$ reactor stage height,

$\rho_{\mathrm{GAS}}=$ average of density of streams entering and exiting the reactor stage

AHGP 3-Stage Regenerator Reactors

$\Delta \mathrm{P}=1.3\left(1 \mathrm{lb} / \mathrm{l} \mathrm{b}_{\mathrm{m}}\right)\left[\left(3.66 \mathrm{lb}_{\mathrm{m}} / \mathrm{ft}^{3}\right)(5.0 \mathrm{ft})+\left(3.20 \mathrm{lb} \mathrm{m}_{\mathrm{m}} / \mathrm{ft}^{3}\right)(10 \mathrm{ft})+\left(3.40 \mathrm{lb} \mathrm{b}_{\mathrm{m}} / \mathrm{ft}^{3}\right)(2.5 \mathrm{ft})\right]\left(1 \mathrm{ft}^{3} / 144 \mathrm{in}^{2}\right)$ $\Delta \mathrm{P}=0.5 \mathrm{psi}$ 


\section{Appendix L Summary of the Process Pressure Drops}

This appendix contains lists of the calculated pressure drops for the DSRP and AHGP at the various feed conditions.

DSRP pressure drops are used to determine the pressure rise needed from the RECYCOMP (sends tailgas to the Desulfurization reactor) and PRESAIR (pressurizes the air fed to the regenerator) Reactor pressure drops are calculated in Appendix H. Pressure drops in other equipment has been assigned without calculations.

Having streams enter the DSRP Reactor at the same pressure (bold pressures) was the starting point for the calculations.

DSRP (base case) \& DSRP-100 \& DSRP-500

\begin{tabular}{lll} 
Equipment & $\Delta \mathrm{P}$ drop (psi) & $\mathrm{P}_{\text {EXIT }}$ (psia) \\
\hline PRESAIR & 13.7 psia inlet P & 278.9 \\
pipe [P-02-N2] & 0 & 278.9 \\
AIR-HX (shell) & 2.0 & 276.9 \\
pipe [HP-O2-N2] & 0 & 276.9 \\
REGENERATOR & 3.3 & 273.6 \\
pipe [ROG] & 0 & 273.6 \\
AIR-HX (tube) & 2.0 & 271.6 \\
pipe [ROG-COOL] & 0 & $\mathbf{2 7 1 . 6}$ \\
DSRP & 2.0 & 268.6 \\
pipe [RXNPRD] & 0 & 268.6 \\
PD-COOLR & 2.0 & 266.6 \\
pipe [COOLPRD] & 0 & 266.6 \\
High Press. Cond. & 2.0 & 264.6 \\
pipe [TAILGAS] & 0 & 264.6 \\
VALVE & 2.6 & 262.0 \\
pipe [TAILGAS2] & 0 & 262.0 \\
RECYCOMP & & 275 \\
& & \\
Coal Gas Slipstream Pressure & \\
Equipment & $\Delta \mathrm{P}$ drop (psi) & P EXIT (psia) \\
Desulfurization Reactor & 0.6 & 274.4 \\
pipe [SLIPSTRM] & 0 & 274.4 \\
VALVE2 & 2.8 & 271.6 \\
pipe [SLPSTRM] & 0 & $\mathbf{2 7 1 . 6}$ \\
& &
\end{tabular}




\section{DSRP-b}

$\begin{array}{lll}\text { Equipment } & \Delta \mathrm{P} \text { drop (psi) } & \mathrm{P}_{\text {EXIT }} \text { (psia) } \\ \text { PRESAIR } & 13.7 \text { psia inlet P } & 279.4 \\ \text { pipe [P-O2-N2] } & 0 & 279.4 \\ \text { AIR-HX (shell) } & 2.0 & 277.4 \\ \text { pipe [HP-O2-N2] } & 0 & 277.4 \\ \text { REGENERATOR } & 4.8 & 272.6 \\ \text { pipe [ROG] } & 0 & 272.6 \\ \text { AIR-HX (tube) } & 2.0 & 270.6 \\ \text { pipe [ROG-COOL] } & 0 & \mathbf{2 7 0 . 6} \\ \text { DSRP } & 3.0 & 267.6 \\ \text { pipe [RXNPRD] } & 0 & 267.6 \\ \text { PD-COOLR } & 2.0 & 265.6 \\ \text { pipe [COOLPRD] } & 0 & 265.6 \\ \text { High Press. Cond. } & 2.0 & 263.6 \\ \text { pipe [TAILGAS] } & 0 & 263.6 \\ \text { VALVE } & 2.6 & 261.0 \\ \text { pipe [TAILGAS2] } & 0 & 261.0 \\ \text { RECYCOMP } & & 275\end{array}$

Coal Gas Slipstream Pressure

\begin{tabular}{lll} 
Equipment & $\Delta \mathrm{P}$ drop (psi) & $\mathrm{P}_{\text {EXIT (psia) }}$ \\
\hline Desulfurization Reactor & 1.6 & 273.4 \\
pipe [SLIPSTRM] & 0 & 273.4 \\
VALVE2 & 2.8 & 270.6 \\
pipe [SLPSTRM] & 0 & $\mathbf{2 7 0 . 6}$
\end{tabular}

\section{DSRP-c}

\begin{tabular}{lll} 
Equipment & $\Delta \mathrm{P}$ drop (psi) & $\mathrm{P}_{\text {EXIT_ }}$ (psia) \\
\hline PRESAIR & 13.7 psia inlet P & 279.3 \\
pipe [P-O2-N2] & 0 & 279.3 \\
AIR-HX (shell) & 2.0 & 277.3 \\
pipe [HP-O2-N2] & 0 & 277.3 \\
REGENERATOR & 3.2 & 274.1 \\
pipe [ROG] & 0 & 274.1 \\
AIR-HX (tube) & 2.0 & 272.1 \\
pipe [ROG-COOL] & 0 & $\mathbf{2 7 2 . 1}$ \\
DSRP & 3.0 & 269.1 \\
pipe [RXNPRD] & 0 & 269.1 \\
PD-COOLR & 2.0 & 267.1 \\
pipe [COOLPRD] & 0 & 267.1 \\
High Press. Cond. & 2.0 & 265.1 \\
pipe [TAILGAS] & 0 & 265.1 \\
VALVE & 2.6 & 262.5 \\
pipe [TAILGAS2] & 0 & 262.5 \\
RECYCOMP & & 275
\end{tabular}




\section{DSRP-c}

Coal Gas Slipstream Pressure

$\begin{array}{lll}\text { Equipment } & \Delta \mathrm{P} \text { drop }(\mathrm{psi}) & \mathrm{P}_{\text {EXIT }} \text { (psia) } \\ \text { Desulfurization Reactor } & 0.06 & 274.9 \\ \text { pipe [SLIPSTRM] } & 0 & 274.9 \\ \text { VALVE2 } & 2.8 & 272.1 \\ \text { pipe [SLPSTRM] } & 0 & \mathbf{2 7 2 . 1}\end{array}$

AHGP pressure drop calculations determine the required $\triangle \mathrm{P}$ for the $\mathrm{SO} 2-\mathrm{COMP}$, compressor. The pressure drop balance is done to insure the $\mathrm{SO}_{2}$ loop with maintain desired pressure. The set pressure (bold) in the $\mathrm{SO}_{2}$ loop is the pressure at the 3-Stage Regenerator exit. This pressure is set to equal the calculated exit pressure of the AHGP Desulfurization reactor (Appendix K).

$\begin{array}{lll}\text { AHGP (base case), \& AHGP-100 \& AHGP-500 } & \\ \text { Equipment } & \Delta \text { P drop (psi) } & \mathrm{P}_{\text {EXIT }} \text { (psia) } \\ \text { 3-Stage Regenerator } & 0.5 \text { (Append. K) } & \mathbf{2 7 4 . 7} \\ \text { pipe [COOLS2] } & 0 & 274.7 \\ \text { HEATX (tube) } & 2.0 & 272.7 \\ \text { pipe [S2V+L] } & 0 & 272.7 \\ \text { COND-EQ } & 2.0 & 270.7 \\ \text { pipe [IN-COND] } & 0 & 270.7 \\ \text { DEMISTR } & 5 & 265.7 \\ \text { pipe [UNP-RSO2] } & 0 & 265.7 \\ \text { SO2-COMP } & & 279.2 \\ \text { pipe [RCYHEATR] } & 0 & 279.2 \\ \text { RCYHEATR } & 2.0 & 277.2 \\ \text { pipe [WARMRCY] } & 0 & 277.2 \\ \text { HEATX (shell) } & 2.0 & 275.2 \\ \text { pipe [FEEDRG1] } & 0 & 275.2 \text { to 3-Stage Regenerator }\end{array}$

\section{AHGP-b}

\begin{tabular}{lll} 
Equipment & $\Delta \mathrm{P}$ drop (psi) & $\mathrm{P}_{\text {EXIT }}$ (psia) \\
\hline 3-Stage Regenerator & 0.5 (Append. K) & $\mathbf{2 7 4 . 1}$ \\
pipe [COOLS2] & 0 & 274.1 \\
HEATX (tube) & 2.0 & 272.1 \\
pipe [S2V+L] & 0 & 272.1 \\
COND-EQ & 2.0 & 270.1 \\
pipe [IN-COND] & 0 & 270.1 \\
DEMISTR & 5 & 265.1 \\
pipe [UNP-RSO2] & 0 & 265.1 \\
SO2-COMP & & 278.6 \\
pipe [RCYHEATR] & 0 & 278.6 \\
RCYHEATR & 2.0 & 276.6 \\
pipe [WARMRCY] & 0 & 276.6 \\
HEATX (shell) & 2.0 & 274.6 \\
pipe [FEEDRG1] & 0 & 274.6 to 3-Stage Regenerator
\end{tabular}




\begin{tabular}{lll} 
AHGP-c & \multicolumn{1}{c}{ } & \\
Equipment & P drop (psi) & $\mathrm{P}_{\text {EXIT }}$ (psia) \\
3-Stage Regenerator & 0.5 (Append. K) & $\mathbf{2 7 4 . 9}$ \\
pipe [COOLS2] & 0 & 274.9 \\
HEATX (tube) & 2.0 & 272.9 \\
pipe [S2V+L] & 0 & 272.9 \\
COND-EQ & 2.0 & 270.9 \\
pipe [IN-COND] & 0 & 270.9 \\
DEMISTR & 5 & 265.9 \\
pipe [UNP-RSO2] & 0 & 265.9 \\
SO2-COMP & & 279.4 \\
pipe [RCYHEATR] & 0 & 279.4 \\
RCYHEATR & 2.0 & 277.4 \\
pipe [WARMRCY] & 0 & 277.4 \\
HEATX (shell) & 2.0 & 275.4 \\
pipe [FEEDRG1] & 0 & 275.4 to 3-Stage Regenerator
\end{tabular}




\section{Appendix M \\ Summary of Major HGD Equipment}

The following tables list equipment required for both HGD processes under various feed conditions. Equipment specifications are also listed in the tables. 


\section{DSRP - base Process Equipment Specifications}

\begin{tabular}{|c|c|c|c|c|c|}
\hline REACTORS & DSRP & DSRP-b & DSRP-c & DSRP-100 & DSRP-500 \\
\hline \multicolumn{6}{|l|}{ Desulfurization reactor } \\
\hline height $(\mathrm{ft})$ & 100 & 100 & 100 & 100 & 100 \\
\hline diameter $(\mathrm{ft})$ & 4.9 & 5.6 & 4.6 & 3.2 & 7.1 \\
\hline weight (lbs) & 70,000 & 90,000 & 63,000 & 31,000 & 140,000 \\
\hline \multicolumn{6}{|l|}{ Desulf. standpipe } \\
\hline height $(\mathrm{ft})$ & 100 & 100 & 100 & 100 & 100 \\
\hline diameter $(\mathrm{ft})$ & 4.9 & 5.6 & 4.6 & 3.2 & 7.1 \\
\hline weight (lbs) & 70,000 & 90,000 & 63,000 & 31,000 & 140,000 \\
\hline \multicolumn{6}{|l|}{ Regeneration reactor } \\
\hline height (ft) & 100 & 100 & 100 & 100 & 100 \\
\hline diameter $(\mathrm{ft})$ & 1.3 & 2.3 & 0.66 & 0.82 & 1.8 \\
\hline weight (lbs) & 6,000 & 17,000 & 2,000 & 3,000 & 11,000 \\
\hline \multicolumn{6}{|l|}{ Regen. standpipe } \\
\hline height $(\mathrm{ft})$ & 100 & 100 & 100 & 100 & 100 \\
\hline diameter $(\mathrm{ft})$ & 1.3 & 2.3 & 0.66 & 0.82 & 1.8 \\
\hline weight (lbs) & 6,000 & 17,000 & 2,000 & 3,000 & 11,000 \\
\hline \multicolumn{6}{|l|}{ DSRP Reactor } \\
\hline height (ft) & 100 & 100 & 100 & 100 & 100 \\
\hline diameter $(\mathrm{ft})$ & 3.8 & 7.0 & 2.0 & 2.5 & 5.4 \\
\hline weight (lbs) & 43,000 & 140,000 & 13,000 & 19,000 & 85,000 \\
\hline \multicolumn{6}{|l|}{ DSRP standpipe } \\
\hline height (ft) & 40 & 40 & 40 & 40 & 40 \\
\hline diameter $(\mathrm{ft})$ & 3.8 & 7.0 & 2.0 & 2.5 & 5.4 \\
\hline weight (lbs) & 27,000 & 89,000 & 8,000 & 12,000 & 540,000 \\
\hline \multicolumn{6}{|l|}{$\begin{array}{l}\text { COMPRESSORS } \\
\text { PRESAIR }\end{array}$} \\
\hline acfh & 570,000 & $1,800,000$ & 160,000 & 240,000 & $1,200,000$ \\
\hline Pin (psia) & 13.7 & 13.7 & 13.7 & 13.7 & 13.7 \\
\hline Pout (psia) & 278.9 & 279.4 & 279.3 & 278.9 & 278.9 \\
\hline power (hp) & 3,300 & 10,000 & 900 & 1,400 & 6,900 \\
\hline stages & 6 & 6 & 6 & 6 & 6 \\
\hline \multicolumn{6}{|l|}{ RECOMP } \\
\hline acfh & 49,000 & 170,000 & 14,000 & 21,000 & 100,000 \\
\hline Pin (psia) & 264.4 & 261 & 262.5 & 264.4 & 264.4 \\
\hline Pout (psia) & 275 & 275 & 275 & 275 & 275 \\
\hline power (hp) & 59 & 227 & 17 & 25 & 124 \\
\hline stages & 1 & 1 & 1 & 1 & 1 \\
\hline \multicolumn{6}{|l|}{$\begin{array}{l}\text { HEAT EXCHANGERS } \\
\text { AIRHX }\end{array}$} \\
\hline Duty (BTU/hr) & $4,300,000$ & $14,000,000$ & $1,200,000$ & $1,900,000$ & $9,600,000$ \\
\hline Area $\left(\mathrm{ft}^{\wedge} 2\right)$ & 700 & 2,200 & 200 & 300 & 1,400 \\
\hline tube mat. & SS 310 & SS 310 & SS 310 & SS 310 & SS 310 \\
\hline shell mat. & SS 304 & SS 304 & SS 304 & SS 304 & SS 304 \\
\hline \multicolumn{6}{|l|}{ DSRP } \\
\hline Duty (BTU/hr) & $15,000,000$ & $51,000,000$ & $4,000,000$ & $6,500,000$ & $31,000,000$ \\
\hline Area $\left(\mathrm{ft}^{\wedge} 2\right)$ & 1,000 & 3,600 & 280 & 450 & 2,200 \\
\hline tube mat. & SS 310 & SS 310 & SS 310 & SS 310 & SS 310 \\
\hline \multicolumn{6}{|l|}{ PDCOOLR } \\
\hline Duty (BTU/hr) & $5,200,000$ & $17,000,000$ & $1,400,000$ & $2,200,000$ & $11,000,000$ \\
\hline Area $\left(\mathrm{ft}^{\wedge} 2\right)$ & 1,000 & 3,200 & 300 & 300 & 2,000 \\
\hline tube mat. & SS 310 & SS 310 & SS 310 & SS 310 & SS 310 \\
\hline shell mat. & SS 310 & SS 310 & SS 310 & SS 310 & SS 310 \\
\hline \multicolumn{6}{|l|}{$\begin{array}{l}\text { MISC. } \\
\text { High Pressure Condenser }\end{array}$} \\
\hline $\begin{array}{r}\text { High Pressure Condenser } \\
\text { Duty (BTU/hr) }\end{array}$ & $10,500,000$ & $35,100,000$ & $2,940,000$ & $4,320,000$ & $21,600,000$ \\
\hline Material & SS 310 & SS 310 & SS 310 & SS 310 & SS 310 \\
\hline \multicolumn{6}{|l|}{ VAPORIZR } \\
\hline Duty (BTU/hr) & 550,000 & $1,900,000$ & 150,000 & 230,000 & $1,100,000$ \\
\hline Material & SS 310 & SS 310 & SS 310 & SS 310 & SS 310 \\
\hline \multicolumn{6}{|l|}{ Storage Tank } \\
\hline vol. $\left(\mathrm{ft}^{\wedge} 3\right)$ & 5,600 & 18,000 & 1,600 & 2,400 & 11,000 \\
\hline Material & SS 310 & SS 310 & SS 310 & SS 310 & SS 310 \\
\hline
\end{tabular}


AHGP Process Equipment Specifications

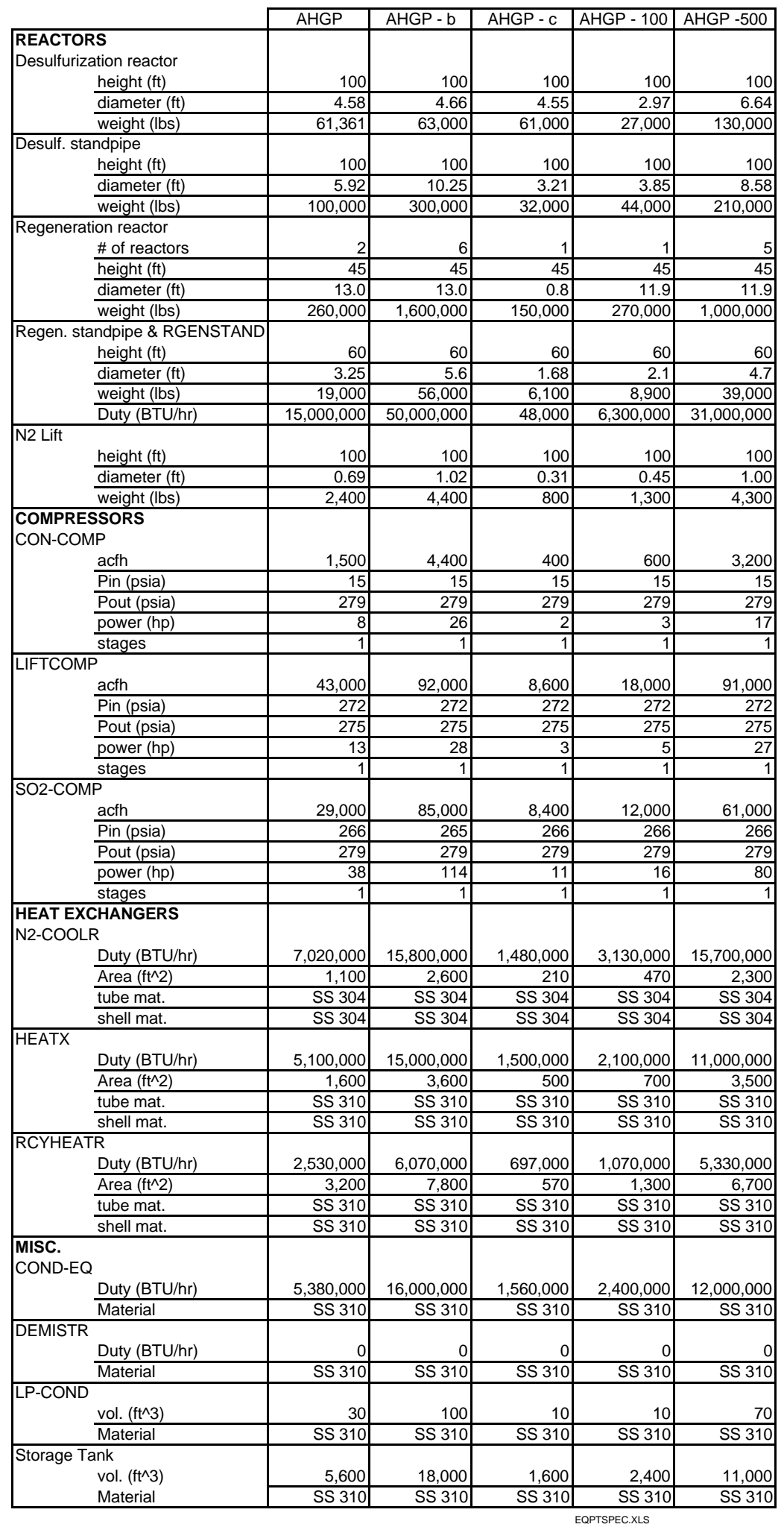


Appendix N

Summary of HGD Costs

The following pages are taken from an Excel spreadsheet containing the culmination of all costs and benefits for all simulated Hot Gas Desulfurization processes. 
DSRP costs

Equipment -Sulfur side

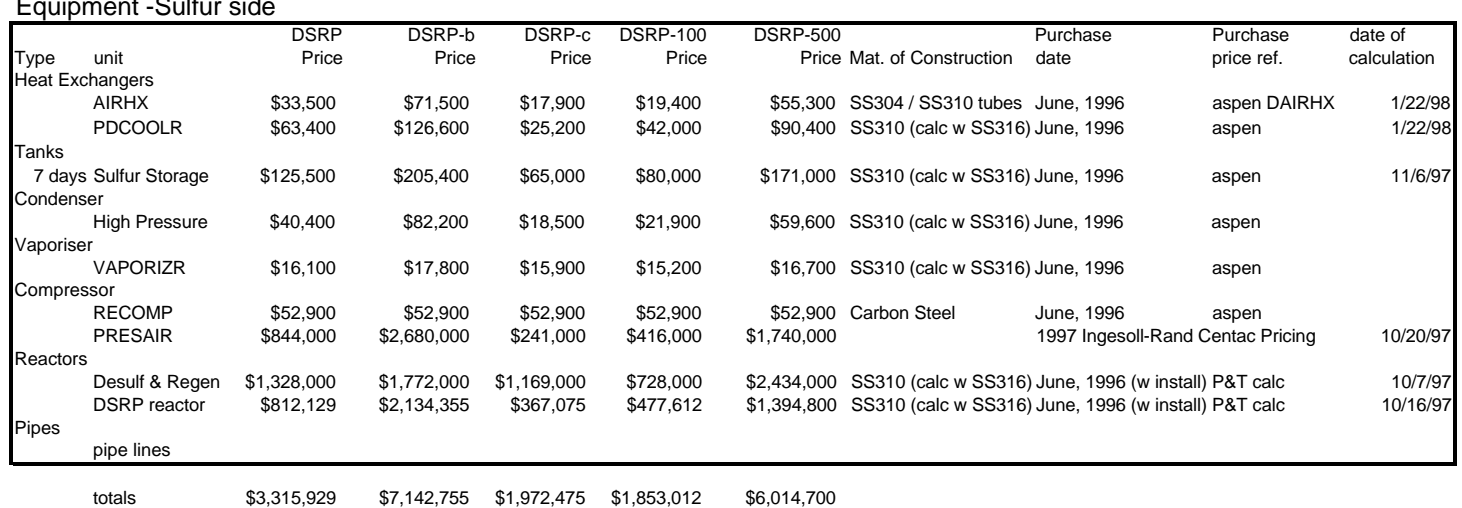

Equipment -Steam side

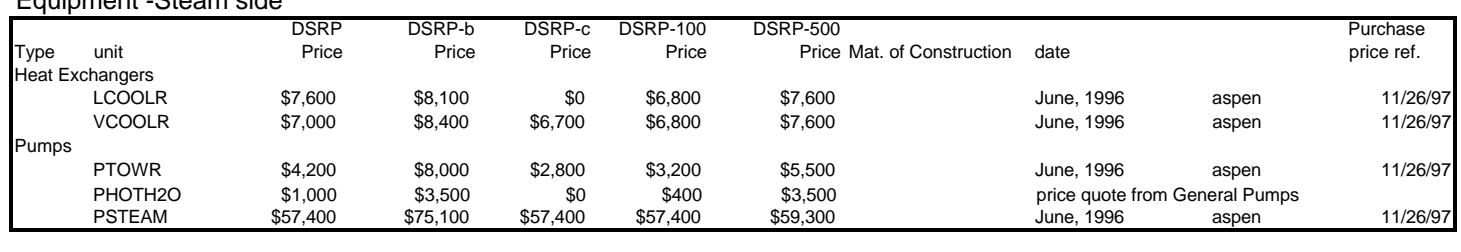

$\begin{array}{llllll}\text { totals } & \$ 77,200 & \$ 103,100 & \$ 66,900 & \$ 74,600 & \$ 83,500\end{array}$

Expendatures

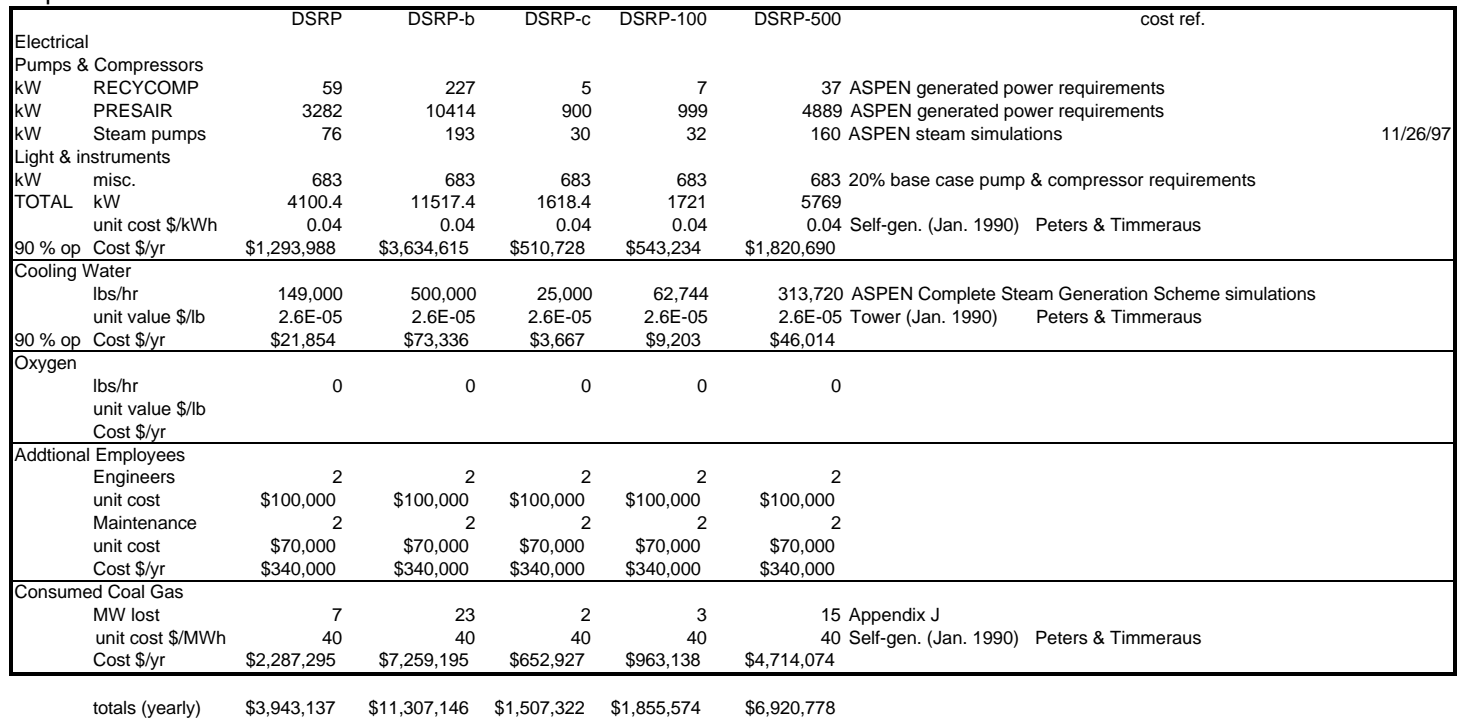

$\begin{array}{llllll}\text { totals (yearly) } & \$ 3,943,137 & \$ 11,307,146 & \$ 1,507,322 & \$ 1,855,574 & \$ 6,920,778\end{array}$

Benefits

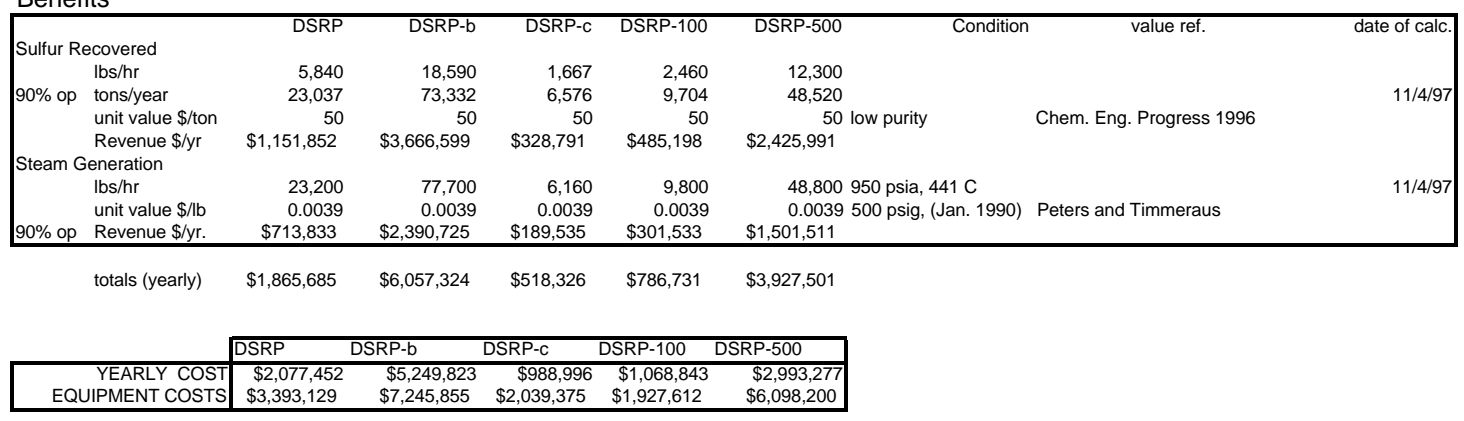




\section{DSRP costs}

Equipment -Sulfur side

\begin{tabular}{|c|c|c|c|c|c|c|c|c|c|}
\hline $\begin{array}{l}\text { Type unit } \\
\text { Heat Exchangers }\end{array}$ & $\begin{array}{r}\text { DSRP } \\
\text { Price }\end{array}$ & $\begin{array}{r}\text { DSRP-b } \\
\text { Price }\end{array}$ & $\begin{array}{r}\text { DSRP-c } \\
\text { Price }\end{array}$ & $\begin{array}{r}\text { DSRP-100 } \\
\text { Price }\end{array}$ & $\begin{array}{r}\text { DSRP-500 } \\
\text { Price }\end{array}$ & Mat. of Construction & $\begin{array}{l}\text { Purchase } \\
\text { date }\end{array}$ & $\begin{array}{l}\text { Purchase } \\
\text { price ref. }\end{array}$ & $\begin{array}{l}\text { date of } \\
\text { calculation }\end{array}$ \\
\hline AIRHX & $\$ 33,500$ & $\$ 71,500$ & $\$ 17,900$ & $\$ 19,400$ & $\$ 55,300$ & SS304 / SS310 tubes & June, 1996 & aspen DAIRHX & $1 / 22 / 98$ \\
\hline PDCOOLR & $\$ 63,400$ & $\$ 126,600$ & $\$ 25,200$ & $\$ 42,000$ & $\$ 90,400$ & SS310 (calc w SS316) & ) June, 1996 & aspen & $1 / 22 / 98$ \\
\hline Tanks & & & & & & & & & \\
\hline $\begin{array}{l}7 \text { days Sulfur Storage } \\
\text { Condenser }\end{array}$ & $\$ 125,500$ & $\$ 205,400$ & $\$ 65,000$ & $\$ 80,000$ & $\$ 171,000$ & SS310 (calc w SS316) & ) June, 1996 & aspen & $11 / 6 / 97$ \\
\hline Vaporiser ${ }^{\text {High Pressure }}$ & $\$ 40,400$ & $\$ 82,200$ & $\$ 18,500$ & $\$ 21,900$ & $\$ 59,600$ & SS310 (calc w SS316) & ) June, 1996 & aspen & \\
\hline $\begin{array}{l}\text { VAPORIZR } \\
\text { Compressor }\end{array}$ & $\$ 16,100$ & $\$ 17,800$ & $\$ 15,900$ & $\$ 15,200$ & $\$ 16,700$ & SS310 (calc w SS316) & ) June, 1996 & aspen & \\
\hline RECOMP & $\$ 52,900$ & $\$ 52,900$ & $\$ 52,900$ & $\$ 52,900$ & $\$ 52,900$ & Carbon Steel & June, 1996 & aspen & \\
\hline PRESAIR & $\$ 844,000$ & $\$ 2,680,000$ & $\$ 241,000$ & $\$ 416,000$ & $\$ 1,740,000$ & & 1997 Ingesoll-Rand C & Centac Pricing & 10/20/97 \\
\hline Reactors & & & & & & & & & \\
\hline Desulf \& Regen & $\$ 1,328,000$ & $\$ 1,772,000$ & $\$ 1,169,000$ & $\$ 728,000$ & $\$ 2,434,000$ & SS310 (calc w SS316) & June, 1996 (w install) & P\&T calc & 10/7/97 \\
\hline $\begin{array}{l}\text { DSRP reactor } \\
\text { pipe lines }\end{array}$ & $\$ 812,129$ & $\$ 2,134,355$ & $\$ 367,075$ & $\$ 477,612$ & $\$ 1,394,800$ & SS310 (calc w SS316) & June, 1996 (w install) & P\&T calc & $10 / 16 / 97$ \\
\hline
\end{tabular}




\section{DSRP costs}

Equipment -Steam side

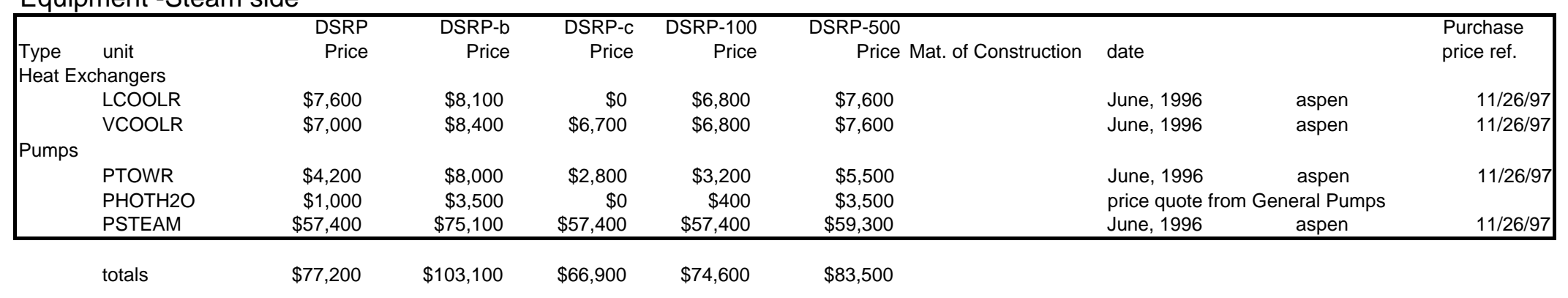




\section{DSRP costs}

\section{Expendatures}

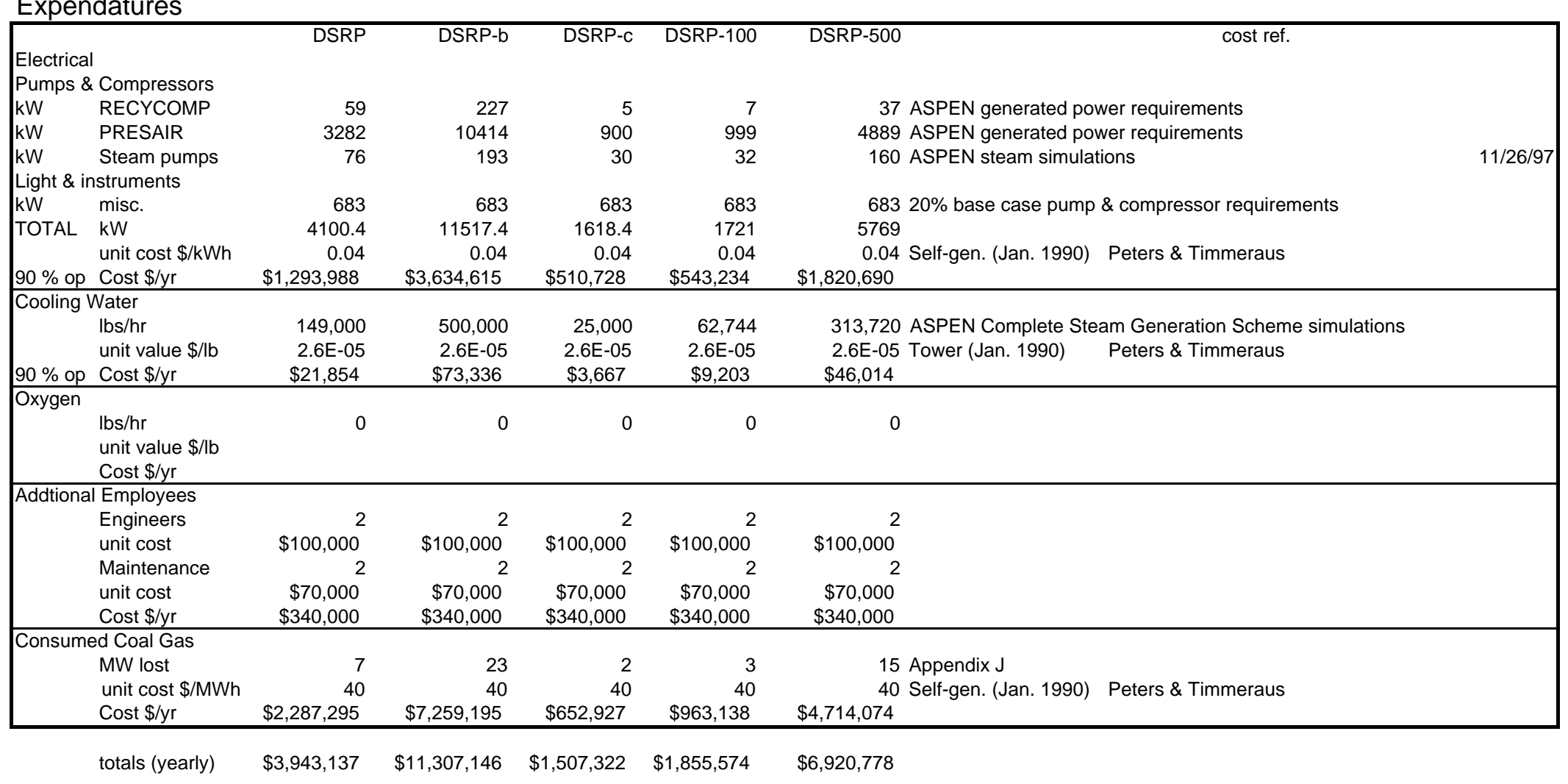




\section{DSRP costs}

Benefits

\begin{tabular}{|c|c|c|c|c|c|c|c|c|c|}
\hline & & DSRP & DSRP-b & DSRP-c & DSRP-100 & DSRP-500 & Condition & value ref. & date of calc. \\
\hline \multicolumn{10}{|c|}{ Sulfur Recovered } \\
\hline & $\mathrm{lbs} / \mathrm{hr}$ & 5,840 & 18,590 & 1,667 & 2,460 & 12,300 & & & \\
\hline \multirow[t]{3}{*}{$90 \%$ op } & tons/year & 23,037 & 73,332 & 6,576 & 9,704 & 48,520 & & & $11 / 4 / 97$ \\
\hline & unit value $\$$ /ton & 50 & 50 & 50 & 50 & 50 & low purity & Chem. Eng. Progress 1996 & \\
\hline & Revenue $\$ / y r$ & $\$ 1,151,852$ & $\$ 3,666,599$ & $\$ 328,791$ & $\$ 485,198$ & $\$ 2,425,991$ & & & \\
\hline \multicolumn{10}{|c|}{ Steam Generation } \\
\hline & $\mathrm{lbs} / \mathrm{hr}$ & 23,200 & 77,700 & 6,160 & 9,800 & 48,800 & 950 psia, $441 \mathrm{C}$ & & $11 / 4 / 97$ \\
\hline & unit value $\$ / l b$ & 0.0039 & 0.0039 & 0.0039 & 0.0039 & 0.0039 & 500 psig, (Jan. 1990) & Peters and Timmeraus & \\
\hline \multirow[t]{3}{*}{$90 \%$ op } & Revenue $\$ / y$ r. & $\$ 713,833$ & $\$ 2,390,725$ & $\$ 189,535$ & $\$ 301,533$ & $\$ 1,501,511$ & & & \\
\hline & \multirow[t]{2}{*}{ totals (yearly) } & $\$ 1,865,685$ & $\$ 6,057,324$ & $\$ 518,326$ & $\$ 786,731$ & $\$ 3,927,501$ & & & \\
\hline & & DSRP & DSRP-b & DSRP-c & DSRP-100 & DSRP-500 & & & \\
\hline trat & YEARLY COST & $\$ 2,077,452$ & $\$ 5,249,823$ & $\$ 988,996$ & $\$ 1,068,843$ & $\$ 2,993,277$ & & & \\
\hline EQL & JIPMENT COSTS & $\$ 3,393,129$ & $\$ 7,245,855$ & $\$ 2,039,375$ & $\$ 1,927,612$ & $\$ 6,098,200$ & & & \\
\hline
\end{tabular}


AHGP Costs

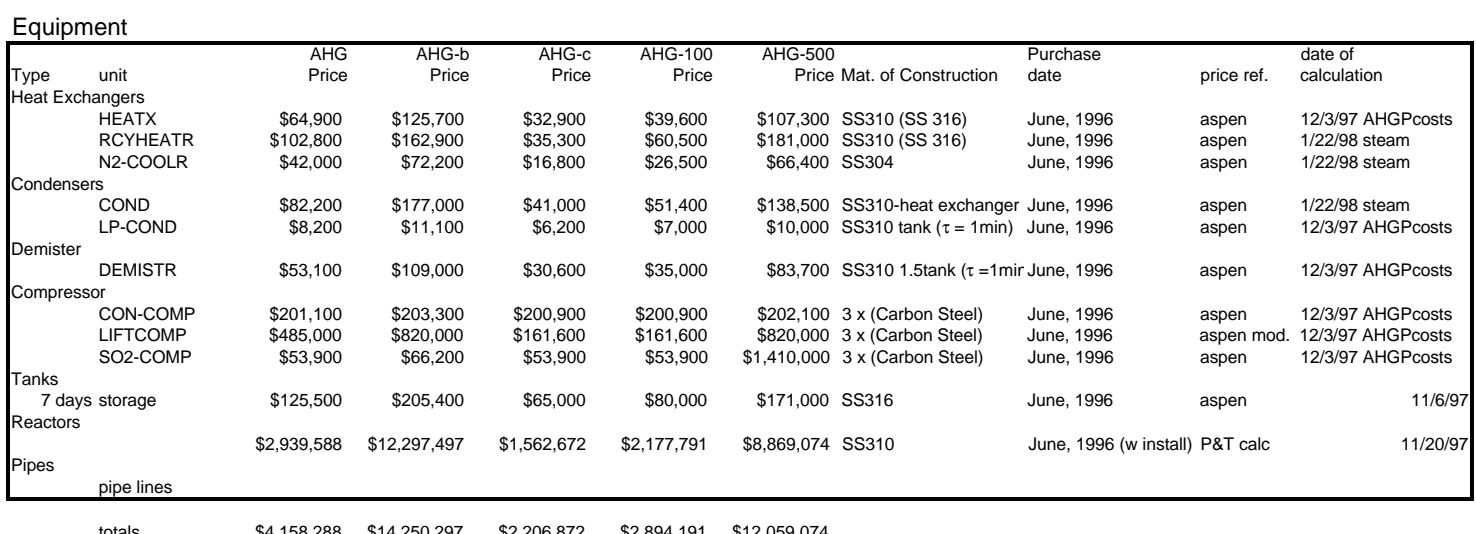

Equipment -Steam side

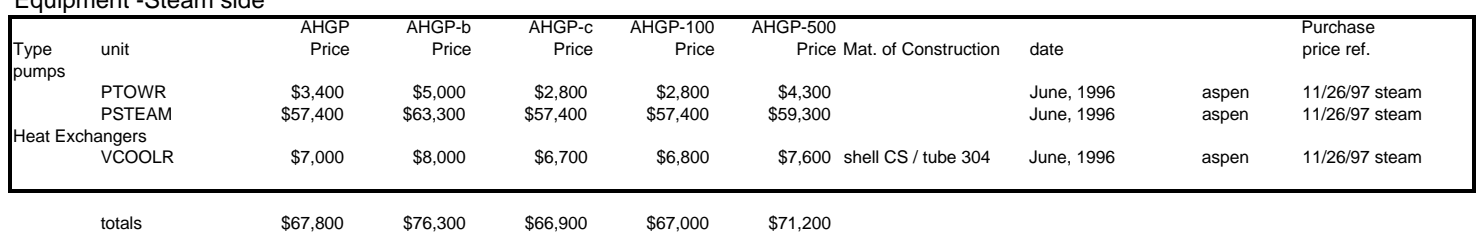

Expendatures

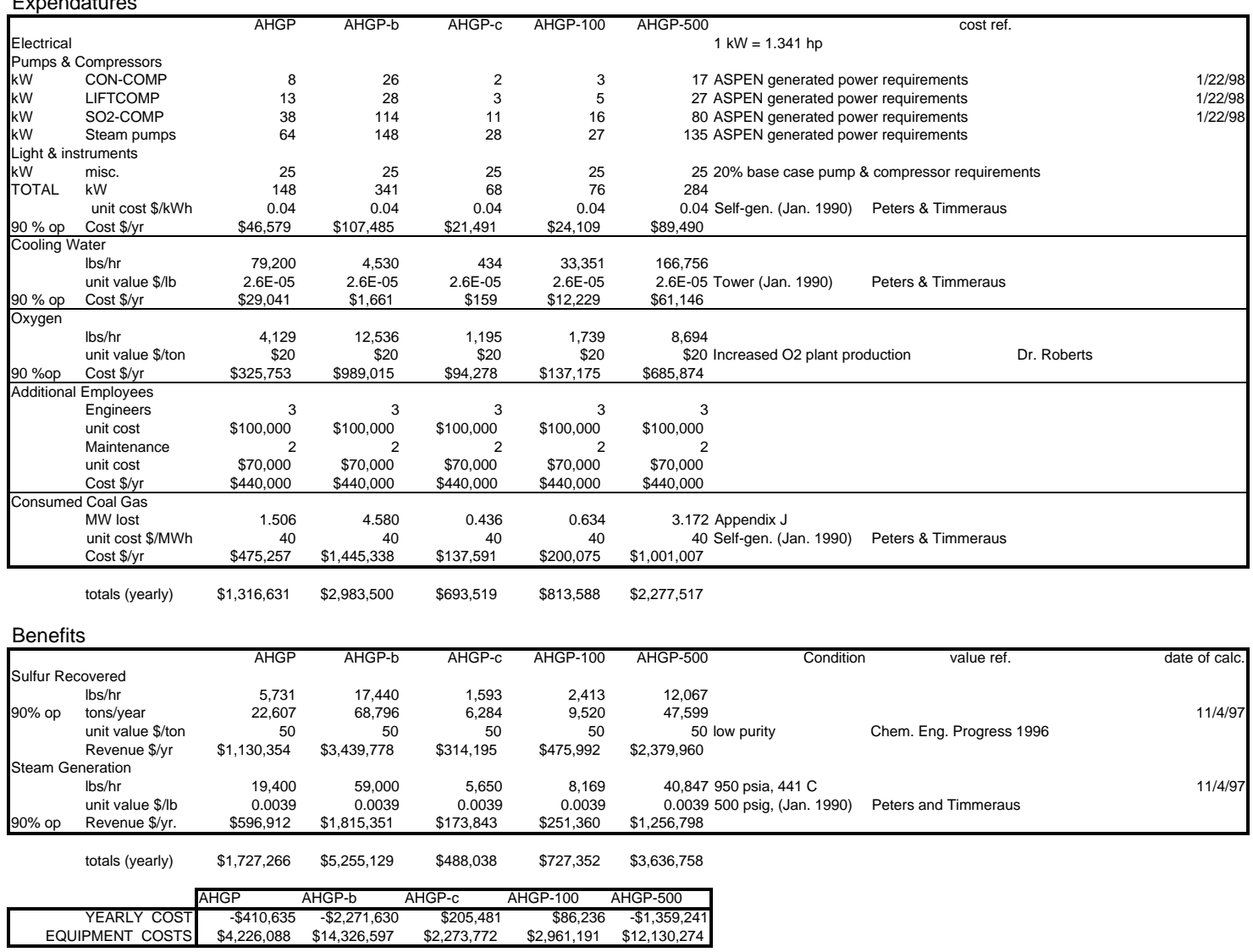




\section{AHGP Costs}

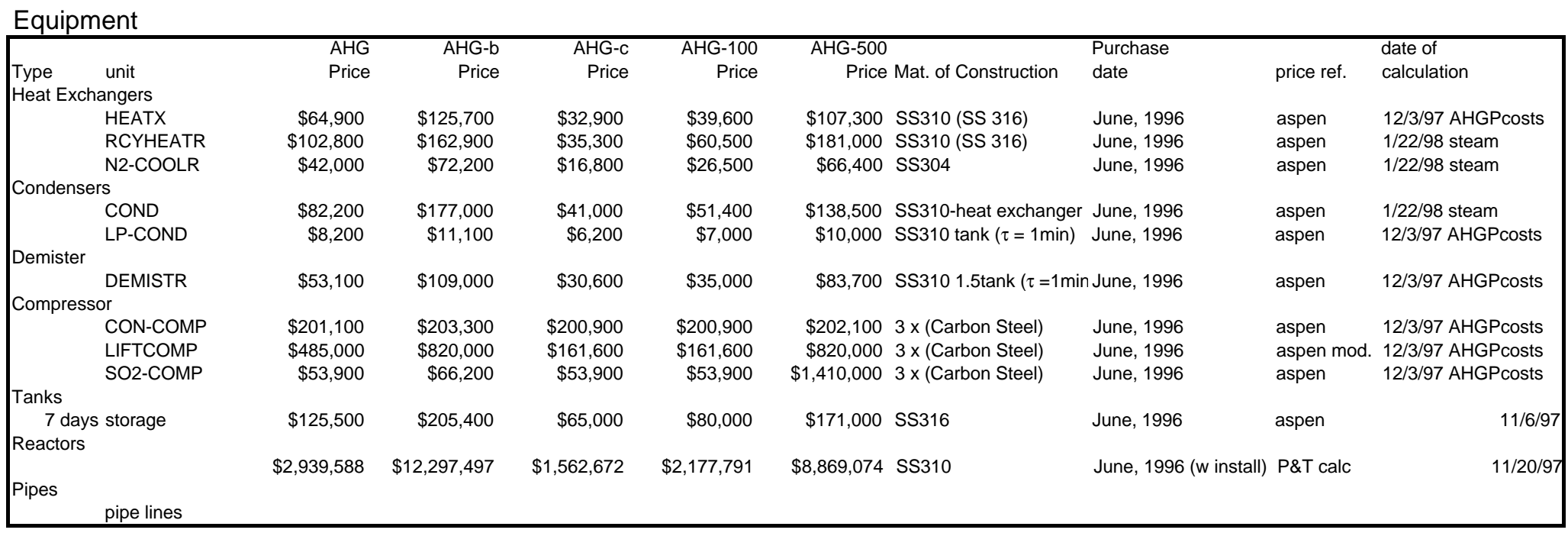

totals

$\$ 4,158,288 \quad \$ 14,250,297$

$\$ 2,206,872$

$\$ 2,894,191 \quad \$ 12,059,074$ 


\section{AHGP Costs}

\begin{tabular}{|c|c|c|c|c|c|c|c|c|c|}
\hline & unit & $\begin{array}{r}\text { AHGP } \\
\text { Price }\end{array}$ & $\begin{array}{r}\text { AHGP-b } \\
\text { Price }\end{array}$ & $\begin{array}{r}\text { AHGP-c } \\
\text { Price }\end{array}$ & $\begin{array}{r}\text { AHGP-100 } \\
\text { Price }\end{array}$ & $\begin{array}{l}\text { AHGP-500 } \\
\text { Price Mat. of Construction }\end{array}$ & date & & $\begin{array}{l}\text { Purchase } \\
\text { price ref. }\end{array}$ \\
\hline & PTOWR & $\$ 3,400$ & $\$ 5,000$ & $\$ 2,800$ & $\$ 2,800$ & $\$ 4,300$ & June, 1996 & aspen & $11 / 26 / 97$ steam \\
\hline & PSTEAM & $\$ 57,400$ & $\$ 63,300$ & $\$ 57,400$ & $\$ 57,400$ & $\$ 59,300$ & June, 1996 & aspen & $11 / 26 / 97$ steam \\
\hline \multicolumn{10}{|c|}{ Heat Exchangers } \\
\hline & VCOOLR & $\$ 7,000$ & $\$ 8,000$ & $\$ 6,700$ & $\$ 6,800$ & $\$ 7,600$ shell CS / tube 304 & June, 1996 & aspen & $11 / 26 / 97$ steam \\
\hline
\end{tabular}

totals

$\$ 67,800$

$\$ 76,300$

$\$ 66,900$

$\$ 67,000$

$\$ 71,200$ 


\section{AHGP Costs}

\begin{tabular}{|c|c|c|c|c|c|c|c|}
\hline \multicolumn{8}{|c|}{ Expendatures } \\
\hline & & AHGP & AHGP-b & AHGP-c & AHGP-100 & AHGP-500 & \\
\hline \multirow{2}{*}{\multicolumn{8}{|c|}{$\begin{array}{l}\text { Electrical } \\
\text { Pumps \& Compressors }\end{array}$}} \\
\hline & & & & & & & \\
\hline \multicolumn{2}{|c|}{$\begin{array}{l}\text { Pumps \& Compressors } \\
\text { kW }\end{array}$} & 8 & 26 & 2 & 3 & 17 ASPEN generated power requirements & $1 / 22 / 98$ \\
\hline $\mathrm{kW}$ & LIFTCOMP & 13 & 28 & 3 & 5 & 27 ASPEN generated power requirements & $1 / 22 / 98$ \\
\hline kW & SO2-COMP & 38 & 114 & 11 & 16 & 80 ASPEN generated power requirements & $1 / 22 / 98$ \\
\hline kW & Steam pumps & 64 & 148 & 28 & 27 & 135 ASPEN generated power requirements & \\
\hline \multicolumn{8}{|c|}{ Light \& instruments } \\
\hline kW & misc. & 25 & 25 & 25 & 25 & \multicolumn{2}{|l|}{$2520 \%$ base case pump \& compressor requirements } \\
\hline \multirow[t]{2}{*}{ TOTAL } & $\mathrm{kW}$ & 148 & 341 & 68 & 76 & 284 & \\
\hline & unit cost $\$ / k W h$ & 0.04 & 0.04 & 0.04 & 0.04 & 0.04 Self-gen. (Jan. 1990) & \\
\hline $90 \%$ op & Cost $\$ / y r$ & $\$ 46,579$ & $\$ 107,485$ & $\$ 21,491$ & $\$ 24,109$ & $\$ 89,490$ & \\
\hline \multicolumn{8}{|c|}{ Cooling Water } \\
\hline & $\mathrm{lbs} / \mathrm{hr}$ & 79,200 & 4,530 & 434 & 33,351 & \multirow{3}{*}{\multicolumn{2}{|c|}{ Peters \& Timmeraus }} \\
\hline & unit value $\$ / \mathrm{lb}$ & $2.6 \mathrm{E}-05$ & $2.6 \mathrm{E}-05$ & $2.6 \mathrm{E}-05$ & $2.6 \mathrm{E}-05$ & & \\
\hline $90 \%$ op & Cost $\$ / y r$ & $\$ 29,041$ & $\$ 1,661$ & $\$ 159$ & $\$ 12,229$ & $\$ 61,146$ & \\
\hline \multicolumn{8}{|l|}{ Oxygen } \\
\hline & lbs/hr & 4,129 & 12,536 & 1,195 & 1,739 & 8,694 & \\
\hline & unit value $\$ /$ ton & $\$ 20$ & $\$ 20$ & $\$ 20$ & $\$ 20$ & \$20 Increased O2 plant production & \\
\hline $90 \%$ \%р & Cost $\$ / y r$ & $\$ 325,753$ & $\$ 989,015$ & $\$ 94,278$ & $\$ 137,175$ & $\$ 685,874$ & \\
\hline \multicolumn{8}{|c|}{ Additional Employees } \\
\hline & Engineers & 3 & 3 & 3 & 3 & \multicolumn{2}{|l|}{3} \\
\hline & unit cost & $\$ 100,000$ & $\$ 100,000$ & $\$ 100,000$ & $\$ 100,000$ & $\$ 100,000$ & \\
\hline & Maintenance & 2 & 2 & 2 & 2 & \multicolumn{2}{|l|}{2} \\
\hline & unit cost & $\$ 70,000$ & $\$ 70,000$ & $\$ 70,000$ & $\$ 70,000$ & \multirow{2}{*}{$\begin{array}{r}\$ 70,000 \\
\$ 440,000\end{array}$} & \\
\hline & Cost $\$ / y r$ & $\$ 440,000$ & $\$ 440,000$ & $\$ 440,000$ & $\$ 440,000$ & & \\
\hline \multicolumn{8}{|c|}{ Consumed Coal Gas } \\
\hline & MW lost & 1.506 & 4.580 & 0.436 & 0.634 & \multirow{2}{*}{\multicolumn{2}{|c|}{ Peters \& Timmeraus }} \\
\hline & unit cost $\$ / M W h$ & & 40 & 40 & 40 & & \\
\hline & Cost $\$ / y r$ & $\$ 475,257$ & $\$ 1,445,338$ & $\$ 137,591$ & $\$ 200,075$ & $\$ 1,001,007$ & \\
\hline
\end{tabular}

totals (yearly)

$\$ 1,316,631$

$\$ 2,983,500$

$\$ 693,519$

$\$ 813,588$

$\$ 2,277,517$ 


\section{AHGP Costs}

\section{Benefits}

\begin{tabular}{|c|c|c|c|c|c|c|c|c|}
\hline \multirow{3}{*}{\multicolumn{2}{|c|}{ Sulfur Recovered }} & AHGP & AHGP-b & AHGP-C & AHGP-100 & AHGP-500 & value ref. & date of calc. \\
\hline & & & & & & & & \\
\hline & & 5,731 & 17,440 & 1,593 & 2,413 & 12,067 & & \\
\hline \multirow[t]{3}{*}{$90 \%$ op } & tons/year & 22,607 & 68,796 & 6,284 & 9,520 & 47,599 & & $11 / 4 / 97$ \\
\hline & unit value $\$ /$ ton & & 50 & 50 & 50 & 50 low purity & Chem. Eng. Progress 1996 & \\
\hline & Revenue $\$ / y r$ & $\$ 1,130,354$ & $\$ 3,439,778$ & $\$ 314,195$ & $\$ 475,992$ & $\$ 2,379,960$ & & \\
\hline \multicolumn{9}{|c|}{ Steam Generation } \\
\hline & $\mathrm{lbs} / \mathrm{hr}$ & 19,400 & 59,000 & 5,650 & 8,169 & 40,847 950 psia, $441 \mathrm{C}$ & & $11 / 4 / 97$ \\
\hline & unit value $\$ / \mathrm{lb}$ & 0.0039 & 0.0039 & 0.0039 & 0.0039 & 0.0039500 psig, (Jan. 1990) & Peters and Timmeraus & \\
\hline \multirow[t]{3}{*}{$90 \%$ op } & Revenue $\$ / y$ r. & $\$ 596,912$ & $\$ 1,815,351$ & $\$ 173,843$ & $\$ 251,360$ & $\$ 1,256,798$ & & \\
\hline & totals (yearly) & $\$ 1,727,266$ & $\$ 5,255,129$ & $\$ 488,038$ & $\$ 727,352$ & $\$ 3,636,758$ & & \\
\hline & & AHGP & AHGP-b & AHGP-C & AHGP-100 & AHGP-500 & & \\
\hline \multirow{2}{*}{\multicolumn{2}{|c|}{$\begin{array}{r}\text { YEARLY COST } \\
\text { EQUIPMENT COSTS }\end{array}$}} & $-\$ 410,635$ & $-\$ 2,271,630$ & $\$ 205,481$ & $\$ 86,236$ & $-\$ 1,359,241$ & & \\
\hline & & $\$ 4,226,088$ & $\$ 14,326,597$ & $\$ 2,273,772$ & $\$ 2,961,191$ & $\$ 12,130,274$ & & \\
\hline
\end{tabular}




\section{Appendix 0 \\ Reaction Data Obtained from RTI}

The following data was obtained during correspondence with RTI.

DSRP reactions at $300 \mathrm{psi}$

\begin{tabular}{lccc} 
Reaction & $\begin{array}{c}\Delta \mathrm{H} \text { at } 550^{\circ} \mathrm{C} \\
(\mathrm{J} / \mathrm{mol})\end{array}$ & $\begin{array}{c}\Delta \mathrm{H} \text { at } 650^{\circ} \mathrm{C} \\
(\mathrm{J} / \mathrm{mol})\end{array}$ & $\begin{array}{c}\Delta \mathrm{H} \text { at } 750^{\circ} \mathrm{C} \\
(\mathrm{J} / \mathrm{mol})\end{array}$ \\
\hline $0.5 \mathrm{SO}_{2}+\mathrm{H}_{2}=(1 / 4) \mathrm{S}_{2}+\mathrm{H}_{2} \mathrm{O}$ & -65128 & -65795 & -66436 \\
$\underline{0.5 \mathrm{SO}_{2}}+\mathrm{CO}=(1 / 4) \underline{\mathrm{S}}_{2}+\mathrm{CO}_{2}$ & -101938 & -101629 & -101295
\end{tabular}.

$\mathrm{ZnO}+\mathrm{H}_{2} \mathrm{~S}(\mathrm{~g})=\mathrm{ZnS}+\mathrm{H}_{2} \mathrm{O}(\mathrm{g})$

$\begin{array}{lllll}\text { Temp. } & \Delta \mathrm{H} & \Delta \mathrm{S} & \Delta \mathrm{G} & \mathrm{K} \\ { }^{\circ} \mathrm{C} & \mathrm{kcal} & \mathrm{cal} & \mathrm{kcal} & \\ 400 & -17.079 & -0.071 & -17.031 & 3.387 \mathrm{E}+5 \\ 500 & -17.056 & -0.040 & -17.025 & 6.502 \mathrm{E}+4 \\ 600 & -17.047 & -0.029 & -17.022 & 1.824 \mathrm{E}+4 \\ 700 & -17.050 & -0.032 & -17.019 & 6.645 \mathrm{E}+3\end{array}$

$\mathrm{ZnS}+1.5 \mathrm{O}_{2}(\mathrm{~g})=\mathrm{ZnO}+\mathrm{SO}_{2}(\mathrm{~g})$

$\begin{array}{lllll}\text { Temp. } & \Delta \mathrm{H} & \Delta \mathrm{S} & \Delta \mathrm{G} & \mathrm{K} \\ { }^{\circ} \mathrm{C} & \mathrm{kcal} & \mathrm{cal} & \mathrm{kcal} & \\ 500 & -107.110 & -18.940 & -92.467 & 1.381 \mathrm{E}+26 \\ 550 & -107.135 & -18.971 & -91.519 & 1.999 \mathrm{E}+24 \\ 600 & -107.155 & -18.995 & -90.570 & 4.694 \mathrm{E}+22 \\ 650 & -107.172 & -19.013 & -89.620 & 1.654 \mathrm{E}+21 \\ 700 & -107.185 & -19.027 & -88.669 & 8.220 \mathrm{E}+19 \\ 750 & -107.195 & -19.038 & -87.717 & 5.474 \mathrm{E}+18 \\ 800 & -107.204 & -19.046 & -86.765 & 4.692 \mathrm{E}+17\end{array}$

